TABLE OF CONTENTS

CHAPTER 1 - GRANITES

1.0 PREFACE

GRANITES

1.1 INTRODUCTION TO CHARACTER OF GRANITIC BOCK

.1 .2 CLASSIFICATION

1.3 CONPOSITION

1.4 STRLCTURE OF GDANITIC ROCK BODIES

1.5 GENESIS

1.6 WEATHERING OF GRAVITIC ROCKS

1.7 DESCRIPTION OF OCCURRENCES

1.8 REFERENCES

\section{GEOMECHANICS OF GRAYTTES}

1.9 INTRODUCTION TO GEC:ECHANICS OF GRANITES

1. 10 IN SITU STRESSES

1.11 :ECPANICAL PROPERTIES

1.12 IHERMAL PROPERTIES

1.13 THERMOELASTIC PROPER:IES

1.14 OTHER CONSIDERATTONS

1.15 SCALING OF LABORATORY RESULTS

1.16 REFERENCES

HYDROLOGY OE GRANITES

1.17 INTRODUCTION TO HYDROLOGï OF GRANITES

1.18 FUNDAIENTALS OF GROUND WATER FLOW

1.19 GROUND WATER FLOW THROUGH SINGLE FRACTURES

1.20 FRACTURE NETWORKS
PAGE NUMBER

$1-1$

$1-4$

$1-5$

$1-6$

$1-10$

1-11

1-12

:.13

1.35

$1-10$

1.45

$1-52$

$1-64$

1-82

$1-100$

$1-108$

$1-123$

$1-129$

$1-130$

$1-135$

1-139

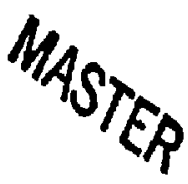

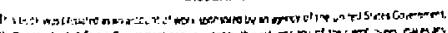

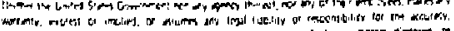

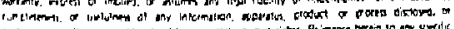

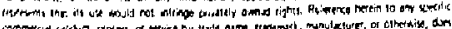




\section{TABLE OF CONTENTS}

CHAPTER 1 (CONT)

PAGE NUMBER

1.21 REGIONAL GROUND WATER FLOW

$1-152$

1.22 EFFECTS OF TEMPERATURE ON FRACTURE FLOW SYSTEMS 1-158

1.23 REFERENCES

$1-160$

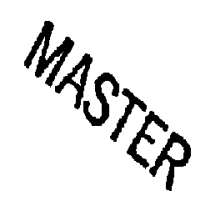


1-2 Granitic occurences chosen for inclusion 1-14 in study

1-3 Engineering classification of intact rock 1-44 based on uniaxial compressive strength and modulus ratio

1-4 Compilation of measurements of the virgin state of stress in the rock

1-5 Increase of average horizontal stress with depth in precambrian rocks

1-6 Variation of principal stresses in the borehole

1-7 Direction of the principal stresses at each measure point plotted

1-8 Axial stress versus strain plots for confining pressures of $0,10,20$ abd $30 \mathrm{NPa}$

1-9 Graph showing variation of Young's modulus and fracture stress $\sigma_{c}$ with confining pressure

1-10 Variation of thermal conductivity with temperature

1-11 Variation of thermal conductivity and diffusivity with temperature

1-12 Variation of themal conductivity with temperature

1-13 Thermal conductivity of selected igneous rocks

1-14 Variation of specific heat with temperature

1-15 Vartation of normalized thermal diffusivity with temperature

1-16 Variation of thermal diffusivity with temperature 


\section{LIST OF FIGURES}

Chapter 1 - continued

PAGE NUMBER

1-18 Typical stress versus strain plot from uniaxial test at $150^{\circ} \mathrm{c}$

1-19 Variation of ultimate compressive stress with temperature

1-20 Strength of rocks and minerals at $5 \mathrm{~kb}$.

1-21 Effect of temperature on stressstrain curves for rocks

1-22 Young's modulus versus temperature

showing $90 \%$ confidence liaits

1-23Poisson ratio versus temperature showing $90 \%$ confidence limits

1-24 Variation of Young's modulus, shear modulus, and Poisson's ratio with temperature

1-25 Variation of linear thermal expansion with temperature

1-26 Variation of coefficient of lithear thermal expansion with temperactire

1-27 Volume thermal expansion of somet conmon minerals

1-28 Average linear expansion of rocks of excellent and very good pierceability

1-29 Average linear expansion of rocks of good and fair pierceabilicy

1-30 Strength-tine relationship for Westerly granite

1-31 Typical creep curve of watersaturated Westerly granite

1-32 A diagram illustrating the effect of size on the unlaxial conpressive strength 0 . qual .2 diorite

1-33 In situ Young's modulus determinations versus fracture density from visual inspection of core 
Chapter 1 - continued

PAGE NLREER

1-34 Histograms of CSM-cell determinations

$1-114$ of Young's modulus

1-35 Curves showing the predicted and measured $1-118$ temperatures as a function of time at a radius of 0.87 in from the mid-points of the two innermost heaters on the $y$-axis

1-36 Predicted isotherms and measured temperacures in a horizontal plane through the middle of the time-scale experiment 90 days after heating had started

1-37 Predicted 1sotherms and measured temperatures in a vertical plane $(y=3.5 \mathrm{~m})$ containing three of the time-scale heaters, 90 days after heating had started

1-38 Predicted isotherms and measured temperatures in a horizontal plane through the middle of the $5 \mathrm{kw}$ full-scale heater, 65 days after heating had started

1-39 Predicted and measured relative displacements between anchor poines 3 m below the heater midplane and the hole collars in the floor of the time-scale drift, plotted as a function of time

1-40 Predicted and measured horizontal displacements of the rock in the mid-plane of the $5 \mathrm{kw}$ full-scale heater taken along different difections

1-41 Predicted and measured horizontal displacements below the $5 \mathrm{kw}$ full-scale heater at anchor points symetrically positioned on each side of the heater

1-42 aracture openings in the geneisses of the Front Range, Colorado, computed from injection tests

1-43 The mean permeability in each depth zone at 4 damsites v.s. the mean depth of midpoints of test sections

1-44 Apparent spacing of Individuals of each of three assumed orthogonal sets of water-bearing fractures at four damsites in geneisses of the Front Range, Colorado, computed from injection tests 
LIST OF FIGURES

Chapter I - Continued

PAGE NURBER

1-45 Sumary of laboratory and in situ

$1-148$

measurements of permeability in

$1-149$

crystalline rocks

1-46 Effect of water-tab!e configuration on

$1-153$

regional ground water flow through

homogeneous isotrople media

1-47 Definition of a representative elementary volume

$1-157$ 
LIST OF TABLES

CHAPTER 1 - GRANITES

PAGE INUBER

1-1 Chemical analyses and mineral norms for average compositione for granite, quartz monzonite and granodiorite

1-2 Consequence of temperature dependence of rock properties on cavern stability

1-3 Stress in ontario rocks

$1-4$ Properties of intact granite

1-5 Intact properties of Barre granite 1-54

1-6 Intact properties of colyille granite unaltered

1-7 Intact properties of Colville granite (slightly altered)

1-8 Intact properties of Pikes Peak granite

1-9 Intact properties of St. Cloud Gray

Granodiorite (Precambrian Granite)

1-10 Comparison of rock propertias

1-11 Conductivity of rocks

I-12 Classification, composition, texture, structure piercing rating, linear thermal expansion, specific heat, and density of 19 Canadian rock minerals

1-13 Specific heat determinations of various samples

1-14 Fusion temperatures of series " $A$ " rocks 1-80

1-15 Fusion temperatures of series "B" rocks 1-81

1-16 Measured coefficients of thermal expansion 1-93

1-17 Mineralogical composition of rocks vs rock- 1-95 removal rate and percent elongation at $600^{\circ} \mathrm{C}$

1-18 Compression tests on granite

1-19 small-scale anisotropy test results 1-101

1-20 Sumary of Anistropic Properties of Granite 1-102

1-2I Values of the exponent $n$ in the equation $1-106$ EnAO in the creep of granite:" and a granodtorite at room temperature 


\section{LIST OF TABLES}

Chapter 1 - continued

PAGE NIMBER

1-22 Rock properties for a generic granite

1-23 Laboratory values for stripa granite used in the simulations

1-24 Hydraulte conductivity and velocity for water flowing through a single fracture

1-25 Fracture data and equivalent fracture apertures for selected fractures at Sambro, Nova Scotia 
The Department of Energy has the responsibility for selecting and constructing Federal repositories for radioactive waste. The Nuclear Regulatory Commission must license such repositories prior to construction. The basic requirement in the geologic disposal of radioactive waste is stated as:

\author{
Placement in a geologic host whereby the radio- \\ active waste is not in mechanical, themal or \\ chemical equilibrium with the object of preventing \\ physical or chemical migration of radionuclides \\ into the biosphere or hydrosphere in hazardous \\ concentration (USGS, 1977).
}

The object of this report is to document the known geologic parameters of large granite and basalt oc urrences in the coterminous United States, for future evaluation in the selection and licensing of radioactive waste repositories.

The report is prepared by willard Owens Associates, Inc., under subcontract to Iawrence Livermore Laboratories for incorporation in the Geoscience Earameter Data Base Handbook being prepared by Lawrence Livermore and the Nuclear segulatory Commission. 
The description of the characteristics of certain potential igneous hosts has been limited to existing data pertaining to the general geologic character, geomechanics, and hydrology of identified occurrences. $A$ description of the geochemistry is the subject of a separate report. 
GRANITES

$1-3$ 


\subsection{INTRODUCTION TO THE GEOLOGIC CHARACTER OF GRANITIC ROCKS}

"Granitic Rock" is defined as a term generally used to signify any coarse-grained, light-colored igneous rock containing essential quartz, In its broadest usage, it may even be loosely applied to certain metamorphic rocks and to guartzfree, light-colored igneous rocks.

Although its broad, undefined use can be confused with the very specific rock name granite, the term has attained a wide casual acceptance. Perhaps the reason for this acceptance of "granitic rock" is that it groups three important igneous rock types that have similar petrographic, tectonic, and genetic characteristics. These types are the granites, monzonites, and granodiorites. They are commonly found occurring as batholiths or huge rock bodies covering hundreds of square kilometers.

Together, granite, monzonite, and granodiorite comprise a major portion of the earth's igneous terrane. Although less common rocks are included in the definition of "ganitic rock," this report and general usage will employ the term for the three major common rock types. 


\subsection{CLASSIFICATION}

Granitic rocks and igneous rocks in general are classified according to texture and mineralogy. Texture is the most obvious and the least complicated. There are two divisions, phaneritic and aphanitic, with one major modifier, porphyritic. Granitic rocks are phaneritic, or coarse-grained. They also may be porphyritic which simply means that there are two distinct grain sizes present. However, with phaneritic rocks, the relative differences in these sizes are not great, and the physical properties of the rock are not greatly affected.

Granitic rocks make up the acidic or high silica $\left(\mathrm{SiO}_{2}\right)$, portion of the classification schemes. These schemes are based on a changing ratio of potassium feldspar $\left(\mathrm{K}_{2} \mathrm{Alsi}_{3} \mathrm{O}_{8}\right)$ to plagioclase felaspar ([Ca,Na]Al[Al, Si]Si $0_{8}$ ) (Figure I-1). As rock types become more silicious, potassium feldspars become dominant. Also, the amount of guartz increases and the calcium to sodium ratio of the plagioclases decreases. 


\subsection{COMPOSITION}

By definition, the mineral composition of the granitic rock series is constrained to certain ranges. These are outlined in Figure 1-1. Total mineral compositions for example granites, monzonites, and granodiorites are given in Table 1-1. From these it can be seen that even though variations occur in the types and nercentages of minor minerals present, the real differences in the rocks occur with the changing guantities of the potassium and plagioclase feldspars. In fact, all three rock types couls have the same minor minerals and still maintain their identity.

These major mineral differences have a distinct efzact on the physical properties of the different roci: types. Since all granitic rocks consist of about 80 percent fe: aspar with quartz and the various feldspars have similar physical properties, all granitic rocks also have similar physical properties.

The mineral changes that classify the granitic rocks have a much greater effect on their chemistry. This effect is apparent from the major oxide compositions shown in Figure 1-1 and the analyses for example granites, monzonites, and granodiorites given in Table 1-1. 


\begin{tabular}{|c|c|c|c|c|c|c|c|c|c|}
\hline \multirow{2}{*}{\multicolumn{2}{|c|}{$\begin{array}{l}\text { ESSENTIAL } \\
\text { MINERALS }\end{array}$}} & \multicolumn{3}{|c|}{$\begin{array}{l}\text { POTASSIUM FELDSPAR } \\
2 / 3 \text { TOTAL FELDSPAR }\end{array}$} & \multicolumn{3}{|c|}{$\begin{array}{l}\text { POTASSIUM FELDSIUM } \\
1 / 3-2 / 3 \text { TOTAL FELLSPAA }\end{array}$} & \multicolumn{2}{|c|}{$\begin{array}{l}\text { PLAGIOCLAFE FELDSPAR } \\
2 / 3 \text { TOTAL FELOSPAR }\end{array}$} \\
\hline & & $\begin{array}{l}\text { Ouantz } \\
>10 \%\end{array}$ & 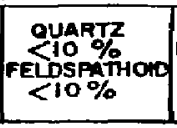 & FELOSPATHOID & QUARTZ & 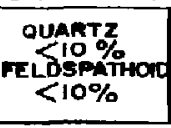 & Feyspomkan & 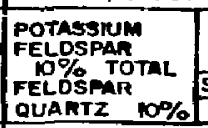 & 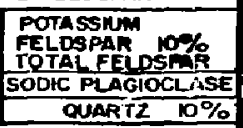 \\
\hline \multicolumn{2}{|c|}{$\begin{array}{l}\text { CHARACTERIZING } \\
\text { ACCESSORY } \\
\text { MINERALS }\end{array}$} & \multicolumn{3}{|c|}{ 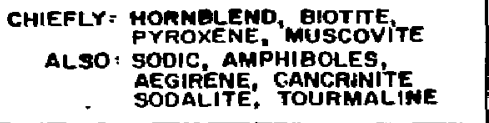 } & \multicolumn{3}{|c|}{ 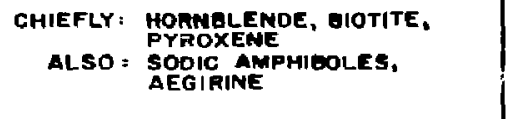 } & \multicolumn{2}{|c|}{ 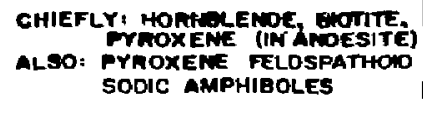 } \\
\hline $\begin{array}{l}\text { AVE } \\
\text { CHE } \\
\text { COM } \\
0\end{array}$ & 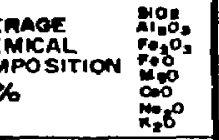 & 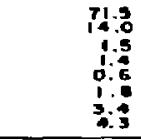 & $\begin{array}{l}0.4 \\
1: 4 \\
2: 2 \\
2: 2 \\
3: 7 \\
3: 1 \\
3: 1 \\
\end{array}$ & $\begin{array}{r}18.2 \\
18: 2 \\
2: \\
1: 6 \\
0: 6 \\
2: 0 \\
3: 3 \\
\end{array}$ & $\begin{array}{r}48.8 \\
15.8 \\
2.3 \\
1.0 \\
1.0 \\
2.8 \\
4.2 \\
4.2\end{array}$ & $\begin{array}{r}910 \\
179 \\
3: 4 \\
3: 4 \\
3: 4 \\
3: 7\end{array}$ & 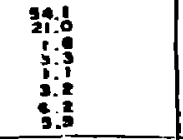 & $\begin{array}{r}8: \\
18: \\
2: \\
1: \\
3: \\
3\end{array}$ & 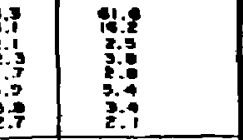 \\
\hline 冚 & ECUIGRANULAR & GRANITE & SYENITE & $\begin{array}{l}\text { NEPHELIME } \\
\text { SYENITS }\end{array}$ & $\begin{array}{l}\text { OUARTZ } \\
\text { MONZONITE }\end{array}$ & monzonit? & $\begin{array}{l}\text { MEPHELMNE } \\
\text { MONZONITE }\end{array}$ & GR ANODIONTE & $\begin{array}{l}\text { OUART2 } \\
\text { DIORITE }\end{array}$ \\
\hline
\end{tabular}

FICURE 1-1 Mineral Composition of Granitic Rocks Source: Trav1s, 1965 
Quartz

\section{Granite Monzonite Granodiorite}

\begin{tabular}{|c|c|c|c|}
\hline $\mathrm{SiO}_{2}$ & 72.08 & 69.15 & 66.88 \\
\hline $\mathrm{TiO}_{2}^{2}$ & 0.37 & 0.56 & 0.57 \\
\hline $\mathrm{Al}_{2} \mathrm{O}_{3}$ & 13.86 & 14.63 & 15.66 \\
\hline $\mathrm{Fe}_{2} \mathrm{C}_{3}$ & 0.86 & 1.22 & 1.33 \\
\hline FeO & 1.67 & 2.27 & 2.59 \\
\hline Mmo & 0.06 & 0.06 & 0.07 \\
\hline MgO & 0.52 & 0.99 & 1.57 \\
\hline $\mathrm{CaO}$ & 1.33 & 2.45 & 3.56 \\
\hline $\mathrm{Na}_{2} \mathrm{O}$ & 3.08 & 3.35 & 3.84 \\
\hline $\mathrm{K}_{2} \mathrm{O}$ & 5.46 & 4.58 & 3.07 \\
\hline $\mathrm{H}_{2} \mathrm{O}$ & 0.53 & 0.54 & 0.65 \\
\hline $\mathrm{P}_{2} \mathrm{O}_{5}$ & 0.18 & 0.20 & 0.21 \\
\hline Quertz $\mathrm{SiO}_{2}$ & 29.2 & 24.8 & 21.9 \\
\hline Orthoclase $\mathrm{MAlSi}_{2} \mathrm{O}_{8}$ & 32.2 & 27.2 & 18.3 \\
\hline Albite NaAlSi ${ }_{2}{ }_{8}$ & 26.2 & 28.3 & 32.5 \\
\hline Anorthite $\mathrm{CaAl}_{2} \mathrm{Si}_{2}{ }^{\mathrm{O}_{8}}$ & 5.6 & 11.1 & 16.4 \\
\hline $\mathrm{C}$ & 0.8 & - & - \\
\hline $\mathrm{CaSiO}_{3}$ & - & - & - \\
\hline $\mathrm{MgSiO}_{3}$ & 1.3 & 2.5 & 3.9 \\
\hline $\mathrm{FeSiO}_{3}$ & 1.7 & 2.2 & 2.9 \\
\hline Magnetite $\mathrm{Fe}_{2} \mathrm{O}_{4}$ & 1.4 & 1.9 & 1.9 \\
\hline Imenite $\mathrm{FeTiO}_{3}$ & 0.8 & 1.1 & 1.1 \\
\hline \multicolumn{4}{|l|}{ Apatite } \\
\hline $\mathrm{Ca}_{5}\left(\mathrm{PO}_{4}\right)_{3}(\mathrm{E}, \mathrm{OH}, \mathrm{Cl})$ & 0.4 & 0.5 & 0.5 \\
\hline No. of analyses & 72 & 121 & 137 \\
\hline
\end{tabular}

Table 1-1. Chemical analyses and mineral norns for average compositions for granite, guartz monzonite, and granodiorite

(from Huảng, 1962) 
As the rocks become more silicious progressing from the diorites to the monzonites to granite, $\mathrm{SiO}_{2}, \mathrm{~K}_{2} \mathrm{O}$, and $\mathrm{Na}_{2} \mathrm{O}$ increase and $\mathrm{Al}_{2} \mathrm{O}_{3}, \mathrm{CaO}, \mathrm{MgO}$, and the iron axides decrease. The change in $\mathrm{SiO}_{3}$ content is due to increasing guartz $\left(\mathrm{SiO}_{2}\right)$ and the higher $\mathrm{SiO}_{2}$ content of the potassium and sodium feldspars. $\mathrm{K}_{2} \mathrm{O}, \mathrm{Na}{ }_{2} \mathrm{O}, \mathrm{CaO}$, and $\mathrm{Al}_{2} \mathrm{Og}_{3}$ changes occur with increasing potassium and sodium feldspars. MgO and iron oxide decrease due to varying types and percentages of minor minerals.

\section{Primary Structure of Granitic Rock Bodies}

Granitic rocks have one other chemical characteristin that sets them apart from all other groups of rocks. This is the occurrence of a tremendously varied suite of trace elements. The number and variety will be different with each rock body but almost all bodies will contain at least some trace concentration of rare elements. Much of the world's mineral wealth is associated with granitic rock bodies that concentrated rare metals during formation. The concentration occurs because metals, other rare elements and a few compounds, such as water, do not have the molecular properties necessary to fit the structures of common minerals that form during rock crystallization. This saves these elements and compounds for the low temperature end of the igneous process. This temperature range is also the range for crystallization of the granitic rocks. 


\subsection{STRUCTURE OF GRANITIC ROCK BODIES}

Granitic rock bodies can occur in any of the many forms assumed by plutonic igneous rocks. Their coarse grain size requires the slow cooling of a plutonic subsurface environment and precludes formation by any surface volcanic mechanism. Although dikes, sills, stocks and other smaller bodies are exceedingly common, by far the greatest volumes of granitic rock now exposed at the earth's surface occur as continental shield complex and orogenic belt batholiths. These great rock bodies tend to be composed of granite, monzonite and/or granodiorite. The less common granitic rock types are only rarely found in large bodies.

Batholiths are igneous rock bodies with an exposed surface area in excess of 100 square kilometers. They are roughly equidimensional or they may have one long dimension. Their vertical dimensions are so great that no lower boundaries have been located. Technically, batholiths must be implaced by the discordant (cutting other structures) intrusion of magma. However, this assumes a purely magmatic origin for granitic rocks. Such $\hbar$. assumption may be misleading.

Granitic rock batholiths occur in the centers of orogenic belts and over large areas of the earth's Precambrian continental shields. Overall they are not restricted to any particular geologic time. 


\subsection{GENESIS}

Generalizations concerning the genesis of the granitic rocks run the risk of oversimplification. Carmichael (Carmichael et al, 1974l states:
"so wide is their (granitic rocks) extent, so varied their relations to crustal depth, thermal environments, metamorphism, tectonism, volcanism, and the flow of time, that generalization inevit- ably obscures with fictitous clarity one of the most complex of igneous phenomena."

However, a few statements can be made concerning present thoughts on genesis of granitic rock batholiths.

Diapiric intrusion of melted, or at least partially nelted, crustal silicious material is thought to be the source of most granitic rock bodies. This, along with local variations in source material, can explain the similarities and differences between the specific rock types. The mechanism for the melting is still argumentative. The orogenic, or mountainbuilding, environment provides the necessary heat and pressure, but how and why is still open to question.

Various methods for in-place granitization must also be able to produce granitic rock batholiths. Melting without injection or granitic alteration by introduced or self-generatea fluids can explain many rock bodies with gradational boundaries. 


\subsection{WEATHERING OF GRANITIC ROCKS}

Granitic rock minerals are relatively resistant to mechanical abrasion. They have a moderate resistance to chemical weathering.

Quartz is very resistant but the potassium feldspars, though more stable than the plagioclases, alter quickly to clay minerals. What ultimate effect weathering will have on a given rock body is determined by the degree of structural fracturing it has sustained. Highly fractured rocks allow greater access for altering fluids. 


\subsection{DESCRIPTION OF OCCURIUENCES}

Introduction

Large, granitic rock occurrences are found in nine major areas of the United States. The nine following areas sh wh on Figure 1-2 were selected for analysis of their parameters for the Data Base Handbook:

Front Range Uplift

Big Horn Uplift

Beartooth Uplift

Wolf River Batholith

Sierza Nevada Batholith

Southern California Batholith

Northern Washington Batholiths

Idaho Batholith

Boulder Batholith

It should be stated that certain specific geologic information for areas of the size under consideration is lacking, because consideration of the geology of an area the size of a batholith reguires generalization of a great many variables. These generalizations are unimportant when 100 plus souare kilometers are involved. But when 1 to 5 square kilometers are under study, these generalizations may not be at all applicable. 


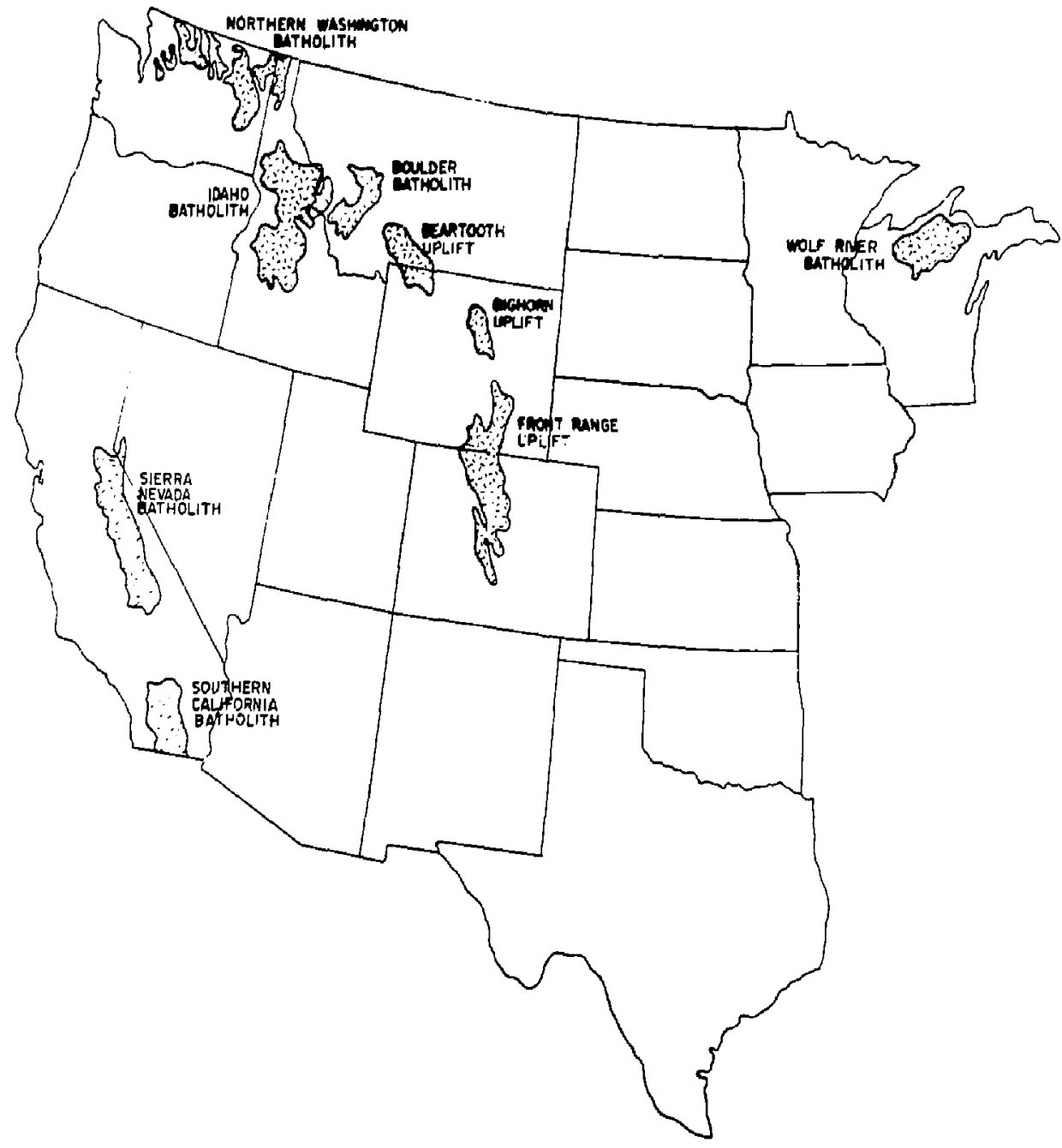

FIGURE 1.2 Granitic occurrences chosen for IncIusion in study 
An example of this problem is the intensity and depih of fracturing in a site area.

First, reiferences on an entire batholith will generalize with a statement such as: there are three "well defined" joint trends. If the reference has been written during the last 20 years, it may not mention minor fracturing at all. Once a specific site is chosen within an occurrence, it may be shown that locally this joint pattern is non-existent or oriented differently; or a local structure may have caused extremely fine grar.ulation of the rock.

Depth of fracturing is even more difficult to determine. It almost always reguires drill hole data. Again, this data may not apply over a large area.

The solution to this problem is simply to work with the generalizations and the more consistent properties of the rock. Once local areas are chosen for stuôy, specific data can be gathered or, if necessary, generated.

Front Range Uplift

\section{Location and Geology}

The Front Range Uplift extends from sourhern Colorado to southern Wyoming along the eastern slope of the Rocky 
Mountains, Elevations range from 1,500 to over 4,000 meters. The rugged terrain is typical of youthful erosion surfaces superimposed on recently uplifted ignecus and metamorphic complexes.

An outline of the geologic history of the aiea begins with the 1.7 billion year-old metamorphic complex. Sediments deposited prior to this time were metamorphosed into the Idaho Springs series and intruded by the Boulder Creek granodiorite batholiths. Najor intrusions and diastrophism occurred again at 1.4 billion years (the silver Dlume granitic suite) and at 1.1 billion years (the Pikes Peak granite). During the Phanerozoic, upjift occurred curing the Carboniferous, the Cretaceous, and the Tertiary. Uplift is silll in progress and the present elevations are due to this recent period. Terrestrial and marine sedimentary ronks deposited throughout the Phanerogenic are still found. The last: period of igneous intrusion, responsible for vol canism and many small granitic rock bodies, began in the cretaceous and continued through the late Tertiary.

The various Precambrian intrusives are the d. ajor granitic rocks of the Front Range Uplift. These occur in an almost continuous series of batholiths along the length of the Uplift. Thejr total area is many million square kilometers. 
The southern Tarryall region, which lies about $100 \mathrm{kilo-}$ meters west of Culorado Springs, Colorado, is typical of the geology and perrolouy of the Front Range Uplift (Hawley and Wobus, 1977). This region is underlain by a large and varied suite of Precambrian intrusive igneous rocks localiy covered by a recently-deposited veneer of sediments of the Tertiary and Quaternary periods. Most of the intrusive rocks are related to one of the three main granitic series of the Fr snt Range: the Boulder Creek Granodiorite, the Silver Plume Quartz Monzonite, and the Pikes Peak Granite.

\section{Petrology}

The composition of the Boulder Creek Granodiorite varies widely from biotite-quartz diorite to granite. Three main lithology types can je distinguished: quartz diorite, granodiorite, and quartz monzonite.

The dominant unit of the Boulder Creek rocks is a quartz monzonite, Texturally, the roci .. usually be classed as a gneiss because of tie foliation that separates the light and dark minerals. The potascium feldspar present is microline; the major plagioclases are oligoclase and andesine; and guartz makes up roughly 30 percent of the ruck. Biotite is the min ferromagnesian mineral and accessory zircon, apatite, magnetite, and sphene occur with it. 
The Silver Plume Quartz Nonzonite is a massive to flowfoliated, plutonic igneous rock correlated with the Silver P1ume Granite of the central Front Range. It occurs in igneous intrusions as large as 13 sguare kilometers and in many dikes. Three varieties of the silver Plume Quartz Monzonite are recognized according to differences in grain size and structure: (1) fine to medium-grained, (2) finegrained, and (3) medium to coarse-grained. All three are found in the Front Range Plutons. The medium to coarsegrained type forms separate plutons; the two finer grained varieties commonly occur together in the same pluton. The rock is generally red and porphyritic and contains microclines, oligaclase, quartz biotite, muscovite with accessory apatite, zircon, monazite and opague oxides.

The Pikes Peak Granite forms massive, sharp-walled plutons. The major Pikes Peak batholith covers at least 3,100 square kilometers. A smaller batholith of Pikes Peak Granite, the Tarryall Mountains mass, underlies a 245 square kilometer area. Pikes Peak Granite consists of a coarse sub-equigranular granite, coarse porphyritic granite and a heterogeneous medium to coarse-grained granite. The batholiths also contain small oikes of pegmatite or aplite and irregular masses of fine-grained granite. The granite averages approximately 50 percent microcline, 30 percent quartz, 15 percent sodic plagioclase, and 5 percent biotite. 
Only thin soils have developed since the last uplift. In areas where closely-spaced joints occur, there has been significant mechanical and chemical weathering. The granitic rocks were exposed to intense weathering during the late Paleozoic and mid-Tertiary. Paleosoils over 25 meters thick can be found where the old surface has been preserved.

\section{Structure}

The Front Range area has undergone at least three major precambrian deformations and three Phanerozoic uplifts. The granite rocks and, to a great extent, the entire area is affected most by the Precambrian tectonics. Three major regional trends occur; northwest, northeast and east. Intense folding and fracturing follow all three, but the northwest is the major trend. The northeast is noted for its mineralization during the Tertiary. All trends have continued to be active into recent times.

\section{Bighorn Uplift}

\section{Location and Geology}

The exposure of granitic rocks in the Bighorn Uplift, located just west of Buffalo and Sherican, Wyoming, occupies an area of about 3,100 square kilometers. Its shape is roughly elliptical, about 100 kilometers long and $48 \mathrm{kilo-}$ 
meters wide at its greatest width. The Precambrian granitic rocks are in contact with the Cambrian Deadwood Formation on all sides. In a few localities, its boundary is defined by faults, along which it is brought into contact with various formations.

The central portion of the uplift is comprised mainly of older, Precambrian true gneiss (metamorphic). At the northern and southern ends of the uplift the major rocks are red to grey younger Precambrian, igneous granitics. These range from granite to quartz diorite in composition and, even though there has been some mobilization, they have mostly been found in place through granitization of the older rocks (Osterwald, 1955).

\section{Fetrology}

Using color as a field criterion, the granitics consist largely of two varieties, a moderately coarse-grained red granitic rock and a medium to fine-grained gray granitic rock. The boundary between the two rock types is gradational, and both are believed to have originated from the same magma. The feldspar in the red granite is mainly orthoclase and microcline with some oligoclase. Quartz is also a major constituent. The red color is caused by the dissemination of small particles of iron minerals in the orthoclase. In some areas, the gray rock contains a higher 
proportion of more calcic plagioclase and grades into a guartz monzonite or quartz diorite. Common accessory minerals in the gray granite are apetite, magnetite, titanite, rutile, and zircon. Much of the gray granite shows evidence of shearing. In weathered portions of the rock, biotite is commonly altered to chlorite and some of the feldspar is altered to kaolinite and sericite (Osterwald, 1955; Darton, 19061 .

Texture of both rock types is typified by migmatization and twin microshearing, gneissic foliation and various sizes of inclusions. These are all common in granitic rocks that have been granitized in place or formed from replacement by metasomatic fluids.

\section{Structure}

A wide-spread joint system is prevalent throughout the granitic outcrop area. This causes the granitics to weather into rounded blocky boulders.

Dikes are common. These are either granitic, granite aplites and pegmatites, or diabasic. No preferred pattern has been recorded. 
Major faulting and folding is generally confined to the margins of the granitic rocks. Thrust, normal and reverse faults occur with mainly dip movement. These and the simple folds of the overlying sediments reflect the movement of the uplift that produced the Bighorn Mountains.

Beartooth Uplift

\section{Location and Geology}

The Pracambrian Beartooth Uplift is located in south central Montana, north and east of Yellowstone National Park. The felsic batholithic mass trends northwest and is approximateiy 97 kilometers long and 48 kilometers wide.

The granitic core of the Beartooth Uplift was formed by granitization of eariy Precambrian sediments about 2.7 billion years ago. The uplift that formed the present Beartooth Mountains started in the Cretaceous and continued into the Tertiary, The volcanism that is still evident in Yellowstone Park began with the later stages of the Uplift.

\section{Petrology}

The rocks, of the granitic core consist mainly of granitic gneiss and granodioritic gneiss. The granitic gneiss consists of about equal amounts of quartz, microcline and sodic 
plagioclase. Minor minerals are biotite, muscovite, magnetite, ilmenite, chlorite, apatite, zircon, and epidote. The granodioritic gneiss is nearly half plagioclase with 43 percent quartz. Microcline is almost totally absent. Minor minerals are similar to the granitic gneiss. Both rocks are foliated.

\section{Structure}

The major structural trend in the Beartooth Mountains is northwest. The present mountains parallel it; the se are Precambrian dikes that follow it; and the prominent cooke City and stillwater structures follow it. The only major variation for this trend are the Cretaceous-Tertiary bounding faults and folds at the ends of the elongated uplift.

\section{Wolf River Batholith}

\section{Location and Geology}

The Precambrian ( 1.5 billion years old) Wolf River Batholith underlies an area of about $9,300 \mathrm{Km}^{2}$ in northeastern Wisconsin. It is surrounded on three sides by older Precambrian plutonic and volcanic rocks of the central and northeastern Wisconsin complexes. The batholith is not apparently related to an orogeny and it is epizonal, or formed near the surface. 
Evidence for this includes widespread development of porphyritic texture, local occurrences of chilled margins, and sharp, discordant intrusive contacts with country rocks. Adjacent metavolcanic and metasedimentary rocks have been contact metamorphosed to hornblende-hornfels, pyroxene-hornfels facies (Van Schmus et al, 1975).

\section{Petrology}

The Wolf River Batholith contains mappable units of granite, guartz monzonite, syenite, monzonite, guartz and feldspar porphyry, and monzonite porphyry. Quartz monzonite is the most common and the most extensively exposed rock type.

Although a porphyritic texture is the most extensively developed in certain rock types of the batholith, Rapakivi texture is more spectacular. The wolf River Batholith is lithologically similar to the Rapakivi massifs of Finland and the classic texture (ellipsoidal potassium feldspar mantled by plagioclasel is well developed in the Wisconsin quartz monozonites.

Perthitic alkali feldspar and quartz are the nost abundant minerals in the batholith, with smaller amounts of sodic plagloclase, iron-rich biotite and amphibole, and locally, olivine and pyroxene (Van Schmus et al, 1975). Typical accessory ninerals are fluorite, zircon, apatite, allanite, ilinenite, and magnetite. 


\section{Joint and Fracturing}

Although numeraus and well-developed near the surface, fractures diminish in size and number with depth. Major fracture patterns in the batholith are oriented $\mathrm{N} .75^{\circ} \mathrm{W} ., \mathrm{N} .30^{\circ} \mathrm{E}$. and N.30 $0^{\circ}$., N.85 $\mathrm{E}$ (Bell and Sherrill, 1974).

\section{Sierra Nevada Batholith}

\section{Lccation and Geology}

The Sierra Nevada Batholith is a group of many granitic plutons which, collectively, form the northwest trending Sierra Nevada mountain range in east central california. The batholith is approximately 644 kilometers long and 80 kilometers wide, and covers approximately 77,700 square kilometers. The Sierra Nevada Batholith was probably formed during the Mesozoic era when the upper layers of the earth's crust were depressed into deeper, more mafic regions. The more silicous rocks melted, migrated upward, and crystalized to form the batholith. For this reason, the base of the granitic batholith is gradational into ultramafic rocks at an approximate depth of 35 kilometers. The batholith has been block-fanlted on the east and tilted westward so that sedimentary rocks lap onto the west side, forming gentle slopes while the east side is steep. 


\section{Petrology}

At least two parent magmas formed the batholith. The eastern side of the batholith is $200 \pm 20$ million years 010 (Triassic Period). Individual plutons consist mainly of quartz monzonites and diorites (Bateman et a1, 1963). Plutons on the vestern side are from the Jurassic period. They generally consist of quartz diorites and granodiorites. The mineralogy of chis massive batholith is difficult to typify because the composition of the rocks will commonly vary from alaskite to quartz jiorite within the zame subsidary pluton. However, the rocks commonly have equigranular, prophyritic or seriate texture, and contain plagioclase, quartz, potassium feldspar, hornblende, biotite, and muscovite (in order of descending abundance).

\section{Structural}

The Sierra Nevada Batholith is thought to occupy the trough of a large synclinorium. The dominant trend within this structure is $\mathrm{N} .40 \mathrm{~W}^{\circ}$ or parallel with the Range itself. All the major strike, normal, and reverse faults follow this trend and all faults have a main strike-slip component. 


\section{Southern California Batholith}

\section{Iocation and Geology}

The Southern California Fatholith has been described as a huge, composite injection dike (Larsen et al, 1958). Formed during the Middle Cretaceous period, the batholith is located in the southern part of California and northern Mexico. The granitic mass is elongated in a northwesterly direction and covers approximately 207,200 square kilometers.

\section{Petrology}

Both the Sierra Nevada Batholith and the Southern California Batholith are composed of several individual plutons. The batholith consiats of what is thought to be a single magma series with rocks ranging from gabbro to granite. The most common rock composition of the batholith is quartz diorite. The mineral percentages of a typical quartz diorite are quartz - 18 percent; microcline - 7 percent; oligoclase - 58 percent; biotite - 7 percent; amphibole - 8 percent; and magnetite - 1 percent. Grain size is irregular with oligoclase forming the larger grams and microcline and quartz occurring as the small grain and interstitial material. 


\section{Structure}

The main trend of the Southern California batholith is nortinwest. Excluding the Transverse Ranges in the same area, this is similar to the rest of Southern California. All the sediments and metamorphics that host the batholith, and most of the linear features within the batholith, strike parallel to this trend. Individual intrusives are elongate to the northwest as are inclusions, gneissic foliation and mineral zones within the intrusions.

References show that the few faults mapped within and adjacent to the granitics also trend northwest. No reference was found for jointing or minor fracture patterns. However, these certainly exist and no doubt also follow the regional trend (Larsen, 1948).

Northern Washington Batholiths

\section{Location and Geology}

The Colville, Chelan, Loon Lake, and Cathedral Batholiths cover about 181 square kilometers in a nearly circular area in northeastern Washington. The four comparably sized batholiths merge toward the south and are considered to be contemporaneous (Hutting et al, 1961). Ige dating of the batholiths is difficult because few cross-cutting relationships 
between the batholiths and surrounding strata are evident. It is commonly believed that the four Mesozoic Batholiths are from the Cretaceous period. Granitization produced the Igneous as well as the gneiss rocks (Campbel1, 1940; Xrauskopf, 1941; Crowder, 1959; Hutting et a1, 1961).

\section{Petrolog:y}

In these four batholiths, rock romposition ranges from alaskite to granodiorite (Pardee, 1918; Waters and Krauskopf, 1941).

The centers of the batholiths commonly consist of light to pinkish-grey, medium-grained, porphyritic granite. This grarite is composed of orthoclase phenocrysts, guartz, plagioclase, and a smaller amount of biotite. Toward the edges of each batholith, granodiorite and quartz diorite become the most common rock types with hornblende increasing to 30 percent of the total rock composition. Lamprophyre and pegmatite dikes commonly intersect the edges of the batholiths.

Quartz diorite gneisses display an unusual, but widespread, swirled follation in the Chelan and Colville Batholiths (Waters, 1938; Waters and Krauskopf, 1941). The texture of the rocks near the contacts of the batholiths varies. The 
Cathedral Batholith border lacks the foliated and cataclastic structure of the Chelan Batholith. It is the only pluton with extensive contact metamorphism and a very unusual contact breccia (up to four miles thick) with hornblende schist as the xenoliths (Waters, 1938).

\section{Jointing and Fracturing}

Northwest trending faults which have had mary episodic displacements are common. Joint patterns are less consistent than the fault patterns. Three sets of widely spaced joints (two vertical and one horizontal) are common throughout (Päciee, 1918).

\section{Idaho Batholith}

\section{Location and Geology}

The Idaho Batholith extends from central Idaho into western Montana. It uxderlies a roughly rectangular-shaped area of about 41,440 square kilometers (Larsen and schmidt, 1958). The Idaho Batholith is relatively flat-topped and is about 836 kilometers long and 137 kilometers in maximum width. The middle Cretaceous age batholith is bounded on the north, east, and west by older rocks while the southern contact is with younjor rocks, chiefly lavas of Tertiary age. The 
Idaho Batholith is in an area of high, rugged mountains, yet over large areas weathering is so deep that the geologic character of the rock cannot be determined.

\section{Petrology}

The Idaho Batholith is made up of several individual rock units. The extreme range in petrology of the rock units is from guariz jabbro to granite, but many of these occur in very small amounts. The range in petrography of the main rock mass is from quartz diorite to quartz monzonite (Larsen and Schmidt, 1958). The average composition is a granodiorite with major guartz, potassium feldspar and plagioclase and minor biotite. Muscovite hornblende or pyroxene, are rare and sphene and apatite are accessories (Ross, 1963). Generally, the rocks are coarse-grained. Some, especially the guartz monzonites and some of the granodiorites, contain phenocrysts of microcline and microperthite as much as 8 centimeters long. The large phenocrysts are unevenly distributed and are abundant in parts of some rock bodies and absent in others. The principal dark minerals of the gabbro are pyroxene and secondary hornblende, those of the tonalite are hornblende with some biotite, and that of the quartz monzonites is almost entirely biotite (Larsen and schmiat, $1958)$. 
The greater part of the Idaho Batholith was probably intruded as a unit or as a number of lạge, intimately related units. Changes in fabric and composition are common, but in many places the different varieties merge into each other without mappable boundaries. The changes record movement in the magma, differentiation and late-stage modifications during the long period required for so large a mass to move into position and consolidate.

\section{Structure}

Because of the size of the Idaho Batholith, the structure and interrelations of the various plutons are complex. Anderson (1952) divides it into two distinct age groups. The old rocks are related to the Sierra Nevada Orogeny granitics of Washington and Oregon. These cover the entire range of com. positions from diorite to granite but granodiorite and guartz monzonite are most conimon. The younger plutons are also guartz monzonite and granodiorite, however, they are Cretaceous to Eocene.

Once in place, the Idaho Batholith played an important role in the crustal deformation that occurred in the western Onited States during the early Tertiary. Along the edges of the batholith, the compressional forces were transmitted to the surrounding rocks and produced great thrust faults and tight folis. 
Within the batholith northwest trending thrusts were complemented by northeast shear zones. These tend to have strikeslip-movement and are accompanied by normal faulting. Where these shears are aligned with regional transverse zones, major strike-slip shears developed. The cour d'Alene's osburn fault is an example (Anderson, 1948).

Local fracturing intensities are related to the major structures. Where a major thrust or shear occurs, the rocks are much more fractured and jointed.

\section{Boulder Batholith}

\section{Location and Geology}

The Boulder Batholith of southwestern Montana is an elongated mass $100 \mathrm{kilometers} 10 \mathrm{ng}$ and $50 \mathrm{kilometers} \mathrm{wide,} \mathrm{trend-}$ ing north-northeastward around Butte, Montana. This batho1ith is of late Cretaceous Age and consists of plutons of guartz monzonite, granodiorite, ard other granitic rocks. It is believed to be a relatively thin mesozonal batholith that was injected into a shallow floor of premagmatic rocks and then covered mainly by its own volcanic ejecta. Geologic field relations and gravity data suggest that the average thickness of the batholith is perhaps 5 kilometers iHamilton and Myers, 1974). 


\section{Petrology}

The composition of igneous rocks in the Boulder Batholith varies from syenogabbro to alaskite, but approximately 75 percent of the batholith is Butte quartz monzonite.

The Butte quartz monzonite contains the following mineral percent ranges:

$\begin{array}{lr}\text { guartz } & 15-408 \\ \text { plagioclase } & 20-48 \% \\ \text { feldspar } & 15-458 \\ \text { biotite } & 1-128 \\ \text { accessories } & 1-38\end{array}$

Accessories include magnetite, sphene, zircon, apatite, allanite, and rutile. Texture is generally equigranular; however, porphyries with potassium feldspar phenocrysts up to three centimeter long do occur (Beczaft, 1963).

\section{Structure}

The thin disk-like structure of the Boulder Batholith presented by Hamilton and Myers (1974) does not fit the classic thick, no-bottom betholith shape. However, their theory is based on inward dipping structures and floor-like features that 
appear to lie beneath the batholith at its north and south edges. This shape makes at least this batholith the equivalent, on a much larger scale, of a lopolith.

The area of Montana underlain by the Boulder Batholith was caught up in the extensive eastward thrusting that took place in the Cretaceous and Tertiary.

In addition, smaller scale thrusting has occurred along the top of the batholith chamber in conjunction with intrusion. Hence, thrust faulting with accompanying strike-slip, shear zones and other union faulting is common.

On a smaller scale, individual areas will have well-developed joint and fracture patterns. A great number of dikes, veins, shear zones, and faults trend east, northeast and north. Yet, in the same area, no pattern for the well-developed joints could be identified. 's: 


\subsection{REFERENCES}

Anderson, A.L., 1952, Multiple unplacement of the Idaho Batholith: Jour. Geol., v. 60, p. 255-265.

Anderson, A.L., 1948, Role of the Idaho Batholith during the Laramide Orogeny: Econ, Geol. V. 43, p. 84-99.

Batemar, P.C., L.D. Clark, N.K, Huber, J.G. Moore and C.D. Rinehart, 1963, The Sierra Nevada Batholith - a synthesis of recent work across the central part: U.S. Geol. Survey Prof. Paper 414D, P, D1-D46.

Bayley and Muehlberger, 1968, Basement Rock Map of the United States: U.S. Geol. Survey, scale 1:2500,000.

Becraft, G.E, and others, 1962, Geology and mineral deposits of the Jefferson City quadrangle, Jefferson and Lewis and Clark Counties, Montana; O.S. Geol. Survey, Prof. Paper 428, p. 100.

Bell, E.A., and M.G. Sherrill, 1974, Water availability in Central Wisconsin, an area of near surface crystalline rcck: 0.s. Geol. Survey Water-Supply Paper 3033, p. 32.

Brown, S.G. and R.C. Newcomb, 1962, Ground tater resources of Cow Valley, Malheur County, oregon: U.S. Geol. Survey Water-Supply Paper, 1619-M, p. 35.

Campbell, C.D., 1940, Structural problems of the east border of the Colville Batholith: (abstract): Geol. Soc. America Bull., v. 51, p. 2019.

Carmichael, I.S.E., Turner, F.J., and Verhoogen, J., 1974, Igneous petrology: McGraw-Hill, New York, p. 740.

Crowder, D.F., 1959, Granitization, migmatization, and fusion in the northern Entiat Mountains, Washington: Geol. Soc. America Bull., v. 70, No. 7, p. 827-878.

Darton, N.H., 1906, Geology 'of the Bighrin Mountains; U.S. Geol. Survey Prof. Paper 51, p. 129.

Eckes.7ann, F.D. and Arie Poldervaart, 1956, Archean history of the Quad Creek area, Part 1. Geologic evolution of the Beartooth Mountains, Montana and Wyoming: Geol. Soc. America Bull., v. 68, p. 1225-1261. 
Foose, R.M., 1961, Structurai Geology of the Beartooth Mountains, Wyoming and Montana: Geol. Soc. Amer. Bull, v. 72, p. 1143-1172.

Gary, $\mathrm{M}_{,}$, and others, eds., 1972, Glossary of Geology: Am. Geol. Inst., p. 805.

Hamilton, W. and W.B. Myers, 1974, Nature of the Boulder Batholith of Montana: Geol. Soc. America Bull, V. 85, p. 365-378,

Hawley, C.C. and R.A. Wobus, 1977, General geology and petrology of the Precambrian crystalline rocks, Park and Jefferson Counties, Colorado: U.S. Geol. Survey Prof. Paper 608-B, P. B1-B77.

Huang, W. T., 1962, Petrology, MCGraw-Hill, New York, p. 480.

Hutting, M.T., W.A.G. Bennett, V.E. Livingston, Jr., and W.S. Moen, 1961, Geologic map of Washington, scale $1: 500,000$.

Hurr, R.T. and D.B. R_chards, 1974, Hydrologic Investigations: Engineering geologic, geophysical, hyàrologic, and cock mechanics investigations of the straight creek Tunnel site and pilot bore, Colorado; in Robinson, C.S., et al; U.S. Geol. Survey Prof. Paper 815-E, P. 79-92.

Krauskopf, K, , 1941, Intrusive rocks of the Okanogan Valley and the problem of their correlation: Jour. Geol., $V$. 49, p. 1-53.

Iarsen, E.S. and R.G. Schmidt, 1958, A reconnaissance of the Idaho Batholith and comparison with the Southern California Batholith: U:S. Geol. Survey Bull. 1070-A, r. 33.

Jarson, E.S., 1948, Batholith and associated rocks of Corona, Elainor, and San Luis Rey quadrangles, southern California: Geol. Survey Amer. Memoir 29, p. 182.

Nichols, T.C. and F.T. Lee, 1966, Preliminary appraisal of applied rock mechanics research on silver Plume Granite, Colorado: U.S. Geol. Survey Prof. Paper 550-C, p. C34-c39.

Diterwald, F.W., 1955, Petrology of the Precambrian granitic in the northern Bighorn, Wyoming, Jour, Geol., V. 63, p. 310-327.

Pardee, J.T., 1918, Geology and mineral deposits of the Colville Indian Reservation, Washington: U.S. Geol. Survey Bul1. 677, p. 11-34. 
Piper, A.M., T.W. Robinson, Jr., and C.F. Park, Jr., 1939, Geology and ground water resources of the Harney Basin, Oregon, U.S. Geol. Survey Water-Supply Paper 841, p. 187.

Raguin, E., 1965, Geology of Granite: Interscience, London, p. 314 .

Redden, J.A., 1968, Ceology of the Berne Quadrangle, Black Hills, South Dakota: U.S. Geol. Survey Prof. Paper $297-$ F, p. $343-408$.

Robinson, C.S., and F.T. Lee, 1974, Engineering geologic, geophysical, hydrologic, and rock-mechanics investigations of the Straight Creek Tunnel site and pilot bore, Colorado gen. geology: O.S. Geol. Survey prof, Paper 815-B, p. 7-25.

Ross, C., 1963, Model composition of the Idaho Batholith: ט.S. Geol. Survey Prof. Paper 475C, P. 80-70.

Taylor, R.B., 1964, Geology of the Duluth Gabbro Complex near Duluth, Minnesota: Minnesota Geol. Survey Bull. 44, p. 63.

Tilling, R.I., 1974, Composition and time relations of plutonic and associated volcanic rocks, Boulder Batholith region, Montana: Geol. Soc. America Bull, V. 85, p. $1925,1930$.

Travis, R. I., 1956, Classification of Rocks: Colorado School of Mines Quart., V. 50 , No. 1, P. 98.

U.S. Department of Energy, Technology for Commercial Radinactive Waste Management, Vol. IV.

Van Schmus, W.R., L.G. Medaris Jr., and P.O. Bazks, 1975, Geology and age of the Wolf River Batholith, Wisconsin: Geol. Soc. America Bull, v. 86, No. 7, p. 907-914.

Waters, A.C., 1938, Petrology of the contact breccias of the Chelan Batholith: Geol. Soc. America Bull, V. 40. p. 763-794.

Watels, A.C., and K.B. Krauskopf, 1941, Protoclastic border of the Colville Batholith: Geol. Society America Bull, v. 52 , No. 9, p. 1355-1417. 


\section{GEOMECHANICS OF GRANITES}




\subsection{INIRODUCTION TO GEOMECHANICS OF GRANITE}

This section presents a review of the major rock mechanics considerations which affect the evaluation of granite as a potential nuclear waste disposal site. It is not the intent to be exhaustive, rather to present the major effects and trends of the principal parameters. Definitions of the major terms used in this discussion may be found in Appendix A.

The most important considerations in designing the excavations for an underground repository for radioactive haste are safety, stability, and longtime security of the excavations. Ideally, one would like to take the results of laboratory experiments performed on small samples of rocks and insert these values into theoretical analyses, and on this basis predict the stability of the openirgs created. Such an approach, however, has not proven to be realistic for a major underground structure. It is limited by the effects of size and geologic structure on the strength of the rock.

Unfortunately, as will be discussed later, there is a great lack of information regarding the effect of sample size on the property measured. Because of the great expense associated with large-scale insitu testing, the primary source of information regarding the properties of rock are obtained from laboratory measurements. 
As will be shown in this report, there is a number of properties which can be adequately described by such laboratory testing procedures. Unfortunately, there are many which cannot. une of the major areas which will require further work is on the procedures by which the input parameters for predictor models can be generated. It is clear from a review of available data that all of the thermal, thermoelastic and mechanical properties of rock are functions of temperature.

until just recently, most testing for determining rosk properties was done at room temperature. The consequences of temperature on various properties are summarized in Table 1-2. with particular reference to the stability of an underground opening (Tsui, 1979). Notice that both conductivity and diffusivity deprease with increasing temperature. specific heat, cn/the other hand, increases with increasing
temperature. Thyse have the ef it of increasing the thermal gradient and hence, increas ; thermal stress. The coefficient of linear thermal expanion increases with increasing temperature. This also has the effect of increasing thermal stress and decreasing the stability of an opering. Young's modulus and compressive strength decrease with increasing tenperature which combine to produce a reduced structural stability for any opening placed in these fields. 
TABLE 1-2. Consequence of temperature dependence of rock properties on cavern otability (Tsui, 1979)

\section{PROPERTIES}

Conductiviey (k)

- Diffusivity (K)

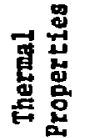

Spectfic Heat (c)

$\dot{5}$

Density ( $\rho)$
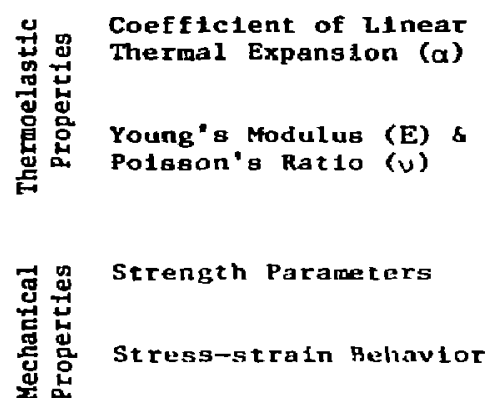

\section{TEMPERATURE DEPENDENCE}

Decrease wth increasing temperature

Increases wth Lncreastin: tempe tature

Negligible In nun-porous rock

Increases with increasing temperature

Decrease with increasing temperature

Decrease wth increasing

Duct 111 ty and flow tenviency increase whth increasing temperature
Consequence on cavern stabtlity

1. Increases cemperature gradient, hence increaseg thermal otress. therefore decreases stability.

2. Reduces the magnitude of cemperature hence thermal atress. therefore, increases stability.

Same effect as decrease in diffusivity

Increases thermal stress and hence decreases stabl11ty

1. Decrease thermal stress, hence Increase etabllity

2. Incrense radial deformation

Decreage stability

Increase radial deformation 
There has been an attempt to classify rocks generically and discuss physical properties in the same way. One type of strength classification is shown in Figure 1-3 for quite a large number of rock types (Deere, 1966). As can be seen, granite is indicated by group 6 (medium to high strength). The variation, even for small laboratory samples, is of the order of a factor of 3. The variation in going from intact rock properties to rock mass properties is ever greater. The reader should keep these variability and scaling considerations in mind when reviewing this report. This section has been divided into the following six topics. They are: Insitu Stresses, Mechanical Properties, Thermal Properties, Thermoelastic Properties, Other Considerations, and Scaling of Laboratory Results. 


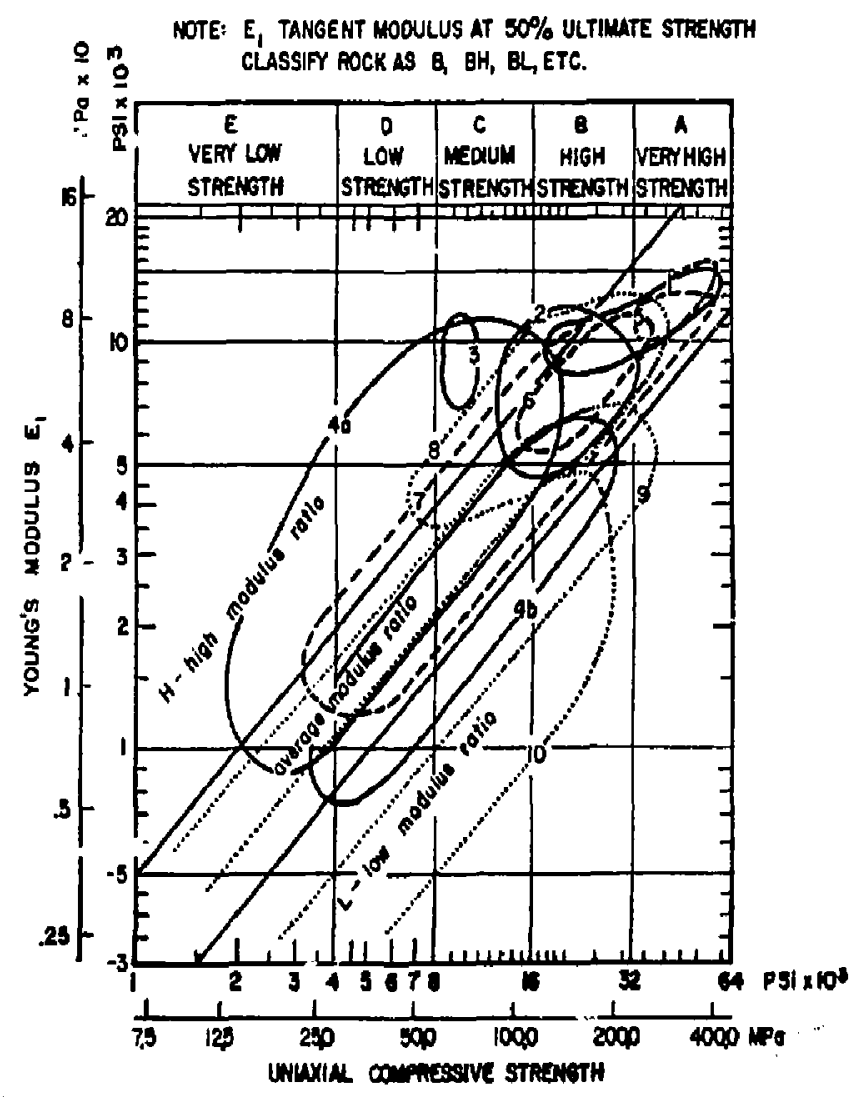

METAMORAHL:-I- QUARTZITE, -2-GKEIS3,-3-MAPULE, -4a-SOHST, STEPP FOLIATOM - 4- SCHIST, RLAT FQLIATIOH.

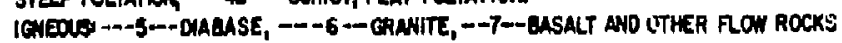
SEDIMENTATY:

EIGURE 1-3 Engineering classification of tatact rock based on unlaxial compressive strength and medulus racio Source: Deere and Miller, 1966. 
The stability of any underground opening is determined by the strength of rock materials and by the stresses which are applied. These stresses are those existing in the ground prior to excavation, those induced during the excavation process, and those. induced by activities after completion of the excavation. The latter category includes the effects of placement of radioactive waste.

In this section, the determination of the state of stress in the vicinity of a potential repository prior to excavation will be emphasized. In general, the vertical component of the insitu stress has a value close to that given by the weight of the overburden. It is, of course, influenced by variations in topography and the time which has passed since the rock was deposited.

A nunber of attempts to neasure the stress field in place has revealed that the horizontal stresses can range from approximately $1 / 3$ of the vertical up to several times the vertical stress. Compilation of these measurements has been done by Hoek and Brown, as shown in Figure 1-4. Note that the envelope at a 1,000 meter-depth, which might be typical for a repository, shows horizontai stress variation from about 0.5 up to 1.75 times the vertical stress. The exact 


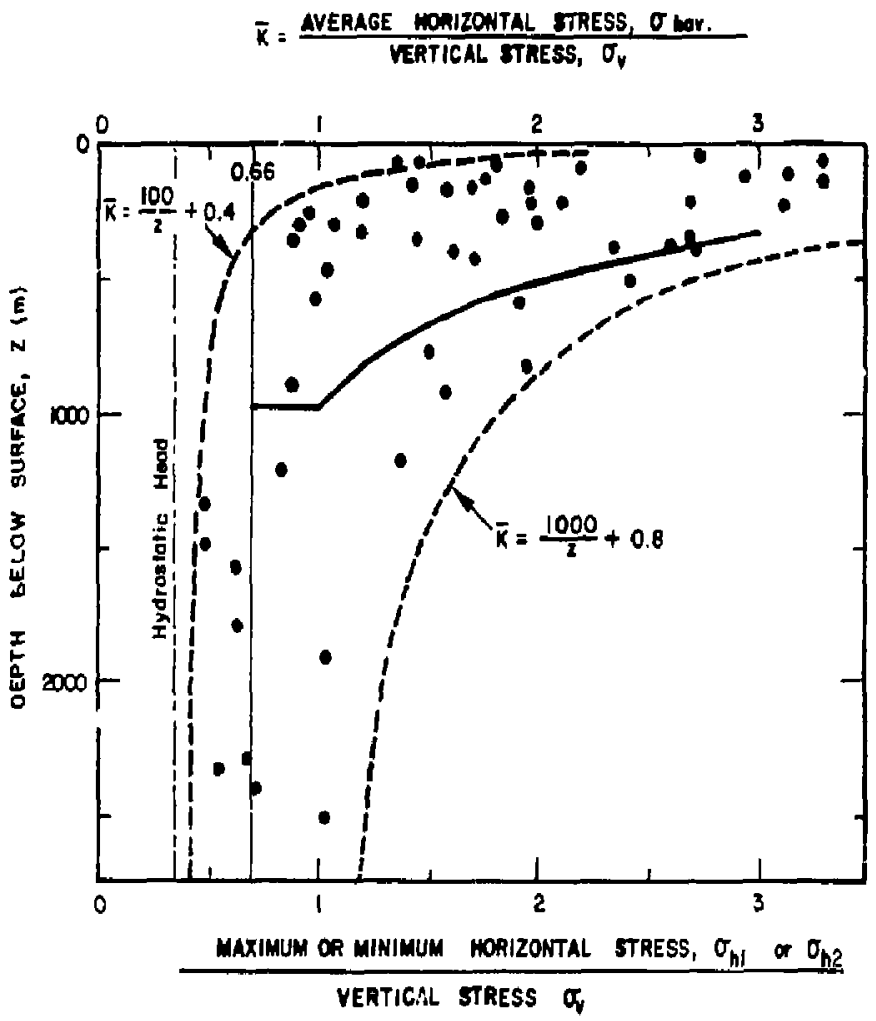

FIGURE 1-4 Compilation of measurements of the virgin state of stress in the rock

Source: Hoek and Brown, 1977. 
stress state is very sife-dependent, and therefore, careful attention has to be placed upon the determination of the stress field at the location of interest.

It is obvious that the stability of an opening will vary considerably if the major principal stress is vertical or horizontal. The best design shape of the opening created will also change depending upon the stress field orientation. Table 1-3 (Lee, 1978; Tsui, 1979) shows the relationship of the stresses for various ages of rock in Ontario. Note that for Devonian age rocks, the horizontal stress is expected to be less than or equal to the vertical. For the older Silurian, Ordovician and Pre-Cambrian rocks, the horizontal stress is expected to be greater than the vertical stress.

A plot of streis variation witi. depth for Pre-Carbrian rocks is shown in Eigure 1-5 (Lee, 1978; Tsui, 1979) for a number of different rock types and locations. There is guite a wise variation, but most of the sites and tests reveal a torizontal stress greater than the vertical. Figures $1-6$ and 1-7 show the results of some stress measurenent work Which was done at the stripa Mine in Sweden (Carlsson, 1978). The variation in principal stress magnitude is shown in Figure 1-6. The principal stress magnitude appears to vary by a factor of 3 over a hole length of about 5 meters. 
TABLE 1-3. Stresses in Ontario rocks.

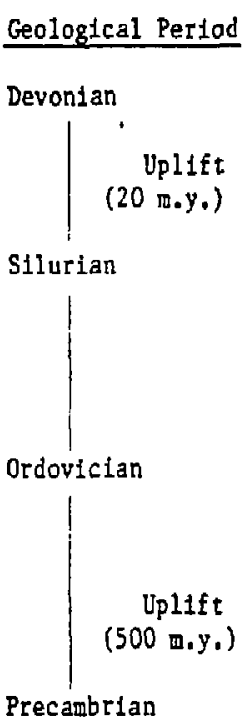

\section{Probable Stress \\ Cond 1tions}

$\sigma_{y} \geq \sigma_{h} \quad$ (?)

$\sigma_{h} \gg \sigma_{v}$

OR

$$
\begin{aligned}
& \sigma_{h} \gg \sigma_{v} \\
& \sigma_{h}=\sigma_{v}
\end{aligned}
$$

Precambrian

$\sigma_{\mathrm{h}}>\sigma_{\mathrm{y}}$

$$
\text { (m\&y. = million year) }
$$

SOURCES: Isu1, 1979 and Lee, 1978. 


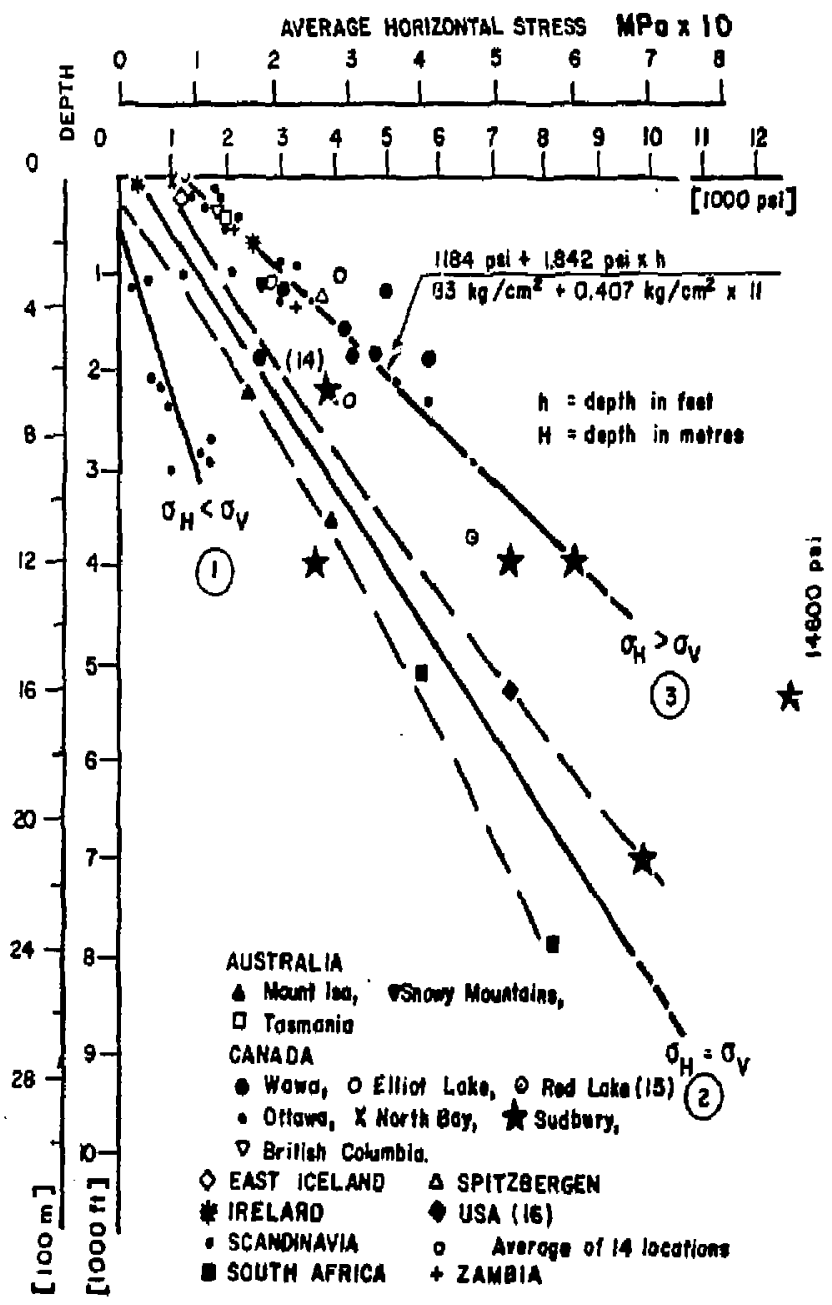

FIGURE 1-5 Increase of average horizontal stress with depth In precambrian rocks Source: Herget et al, 1975. 


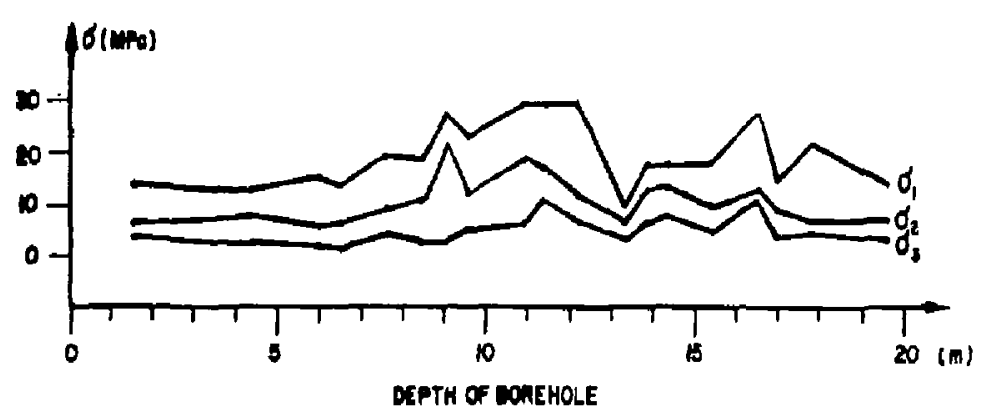

FIGURE 1-6 Variation of principal atresses in the borehole Source: Carlsson, 1978.

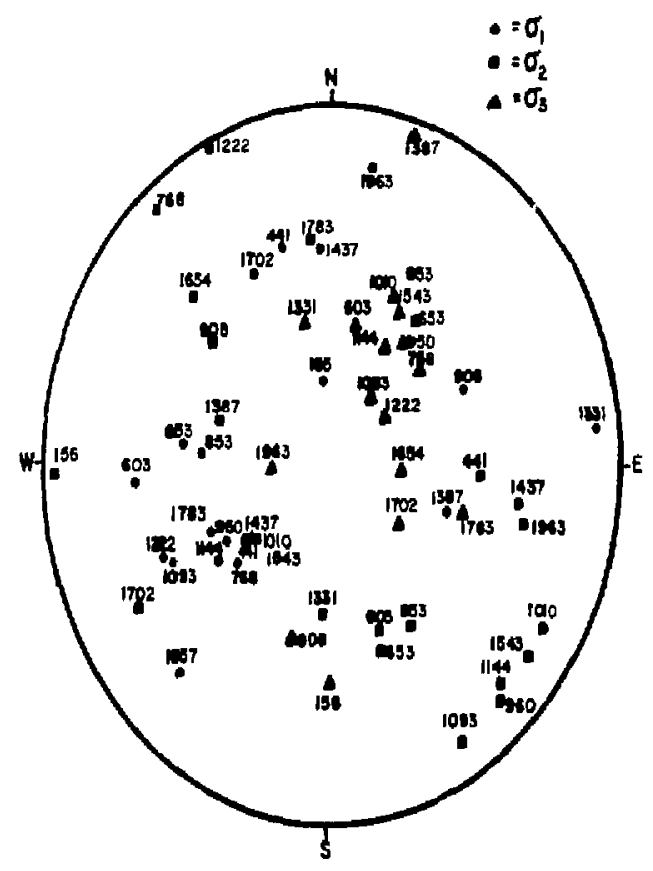

FIGURE 1-7 DIrection of the principal stresses at each zeasuze point plotted Source: Carlsson, 1978.

Note: Depth of rensurenent in the borehole is indicated on Wullf's net lower hewisphere. 
Variajility in principal stress direction is shown in Figure 1-5. Again, the variation is considerable. In general, stress fields are found to be very site specific and may vary significantly even within a specific rock mass. 


\subsection{M_GHANICAL PROPERTIES}

Mechanical properties which are normally consiered in any description of a rorte material are index properties (such as unit weight or density), moisture content, porosity, stressstrain relationships, which yield Young's modulus and Poisson's ratio, and rock strength as measured by the compressive and tensile strength.

A summary of properties for intact granite are given in Table 1.4. These values have been collected during a literature review (ONWI, 1978) of a large number of published reports. Note that even properties such as unit weight, which is normally considered relatively constant for granite, varies from 2310 to $3040 \mathrm{~kg} / \mathrm{m}^{3}$. The porosity varies from about $0.05 \%$ to $11 \%$. Young's modulus varies by a factor of 5 and Poisson's ratio by a factor of 9 or 10 . The compressive strength varies from 34 to $350 \mathrm{MPa}$. Although tensile strength is shown to vary from about 3.5 to $55 \mathrm{MPa}$, those samples which are already broken, of course, are not tested, so the variation should actui $1.1 \mathrm{y}$ be from 0 to $55 \mathrm{MPa}$.

A sumary of properties for various types of granite are shown in Tables 1.5 to 1.9. A11 of the granites chosen are from quarries. Therefore, they have some properties which 
TABLE 1-4 Properties of Intact Granite

\begin{tabular}{|c|c|c|c|c|c|}
\hline Type of Property & Parameter & Symbo1 & Mean* & Range & MKS Un1t \\
\hline \multirow[t]{3}{*}{ Index } & Unit Weight & & 2646.5 & $2306.9-3043.8$ & $\mathrm{~kg} / \mathrm{m}^{3}$ \\
\hline & $\begin{array}{l}\text { Natural moisture } \\
\text { content (Intact) }\end{array}$ & & -- & 0.0 .32 & $\%$ \\
\hline & Porosity (rock mass) & & 1.6 & $0.05-11.2$ & $\%$ \\
\hline \multirow[t]{2}{*}{ Stress-strain } & Young's Madulus & & 50.3 & $15.9-83.4$ & GPa \\
\hline & Polsson's Ratio & & 0.18 & $0.045-0.39$ & -- \\
\hline \multirow[t]{2}{*}{ strength } & $\begin{array}{l}\text { Un1axta1 Compressive } \\
\text { Strength }\end{array}$ & & 175.1 & $35.2-353.1$ & MPa \\
\hline & Tensile Strength & & 6.3 & $3.4-55.9$ & MPa \\
\hline \multirow[t]{4}{*}{ Therma1 } & $\begin{array}{l}\text { Coefficient of Linear } \\
\text { Thermal Expansion }\end{array}$ & & $2.5 \times 10^{-6}$ & $1.67 \times 10^{-6}-3.34 \times 10^{-6}$ & ${ }^{a} \mathrm{C}^{-1}$ \\
\hline & Heat Capacity & & 0.92 & $0.67-1.38$ & $\mathrm{~J} / \mathrm{g}-{ }^{\circ} \mathrm{C}$ \\
\hline & Thermal Conductivity & & TEMPERATURE & GONDUCTIVITY & \\
\hline & & & $\begin{array}{r}0^{\circ} \mathrm{C} \\
50^{\circ} \mathrm{C} \\
100^{\circ} \mathrm{C} \\
150^{\circ} \mathrm{C} \\
200^{\circ} \mathrm{C} \\
300^{\circ} \mathrm{C} \\
400^{\circ} \mathrm{C}\end{array}$ & $\begin{array}{l}2.86 \mathrm{w} / \mathrm{m} \mathrm{K} \\
2.70 \\
2.56 \\
2.44 \\
2.34 \\
2.15 \\
1.99\end{array}$ & \\
\hline
\end{tabular}


TABLE 1-5 Intact properties of Barre Granite.

BASIC PARAMETERS

Type of Property

Index

Stress-6train

Strength

Thermal

Hydrological $\underline{\text { Parameter }}$

Unit Weight

Natural moisture

content (intact)

Porosity (rock mass)

Young's Modulus

Poisson's Ratio

Bulk Modulus

Shear Modulus

Cohesiot.

Friction Angle MPa range

Uniaxial Compressive

Strength

Tensile Strength

Coefficient of Linear

Thermal Expansion

Heat Capacity

Thermal Conductivity

Horizontal Permeability
MRS Units

$2659.3 \mathrm{~kg} / \mathrm{m}^{3}$

$0.32 \%$

$0.4 \%$

$72.4 \mathrm{GPa}$

0.22

43.1GPa

$29.7 \mathrm{Gpa}$

$7.2 \mathrm{MPa}$

45 degrees

$234.5 \mathrm{MPa}$

7.6MPa

$2.22 \times 10^{-6} 0^{\circ} \mathrm{C}^{-\mathrm{I}}$

$0.9^{n} \mathrm{~J} / \mathrm{g}^{\circ}{ }^{\circ} \mathrm{C}$

$2.37 \mathrm{w} / \mathrm{m}^{\circ} \mathrm{K}$

less than $1 \times 10^{-4}$ $\mathrm{cm} / \mathrm{sec}$

SOURCE: Office of Waste Isolation, 1978 
TABLE 1-6. Intact properties of colville Granite (unaltered).

\section{BASIC PARAMETERS}

Type of Property

Index

Stress-strain

Strength

Thermal
Parameter

Unit Weight

Natural moIsture

content (Intact)

Porosity (rock mass)

Young's Modulus

Poisson's Ratio

Bulk Modulus

Shear Modulus

Cohesion 10.3-24.1

Friction Angle MPa range

Uniaxial Compressive

Strength

Tensile Strength

Coefficient of Linear

Thermal Expansion

Heat Capacity

Thermal Conductivity
MES Units

$2627.3 \mathrm{~kg} / \mathrm{m}^{3}$

$0.6 \%$

$1.59 \%$

$35.96 \mathrm{~Pa}$

$0.15-$

$17.2 \mathrm{GPa}$

$15.9 \mathrm{GPa}$

22.4MP a

58 degrees

$144.8 \mathrm{MPa}$

7.4 (est.) MPa

Hydrological

*linear stress-strain curve assumed.

SOURCE: Office of Waste Isolation, 1978 
TABLE 1-7. Intact proporties of Colville Granite (slightly altered)

\section{BASIC PARAMETERS}

Type of Property

Index

Stress-strain

Strength

Thermal

SOURCE: Office of Waste Isolation, 1978

Thermal Expansion

Heat Capacity

Hydrological

*Linear stress-straln curve assumed.
MRS Units

$2609.7 \mathrm{~kg} / \mathrm{m}^{3}$

$1.0 \%$ (est.)

$2.36 \%$

11. OGPa

$0.20--$

$6.2 \mathrm{GPa}$

4.8GPa

Shear Modulus

10.3-24.1 9.8MPa

Coheston

$M P a$ range

58 degrees

Uniaxial Compressive

Strength

64.8MPa

Tensile Strength

3.2 (est.) $\mathrm{MPa}$

Coefficient of Linear

Thermal Conductivity 
TABLE 1 8. Intact properties of P1kes Peak Grante.

\section{BASIC PARAMETERS}

Type of Property

Index

Stress-strain

Strength

Thermal

SOURCE: Office of Waste Isolation, 1978

Thermal Expansion

Heat Capacity

Hydrological
MRS Units

$$
\text { Unit Weight }
$$

$2636.9 \mathrm{~kg} / \mathrm{m}^{3}$

Natural moisture

content (intact)

$.10 \%$

Porosity (rock mass)

Young's Modulus

$70.669 a$

Poisson's Ratio $.31--$

Bulk Modulus

$62.0 \mathrm{GPa}$

Shear Modulus

26.96693

Cohesion

$10.3-24.1$

Friction Angle MPa range

Uniaxial Compressive

Strength

226.2MPa

Tensile Strength

11. 9MPa

Coefficient of Linear

Thermal Conductivity 
IABLE 1-9:. Intact properties of St. Cloud Gray Granodiorite. (Precambrian Granite)

\section{BASIC PARAMETERS}

Type of Propert.

Index

Stress-strain

Strength

Therifal

Fiydrological
Parameter

Unit Weight

Natural moisture

content (Intact)

Porosity (rock mass)

Young's Modulus

Polsson's Ratio

Bulk Modulus

Shear Modulus

$$
\begin{aligned}
& \text { Cohesion 10.3-24.1 } \\
& \text { Friction Angle MPa range } \\
& \text { Uniaxial Compressive } \\
& \text { Strength }
\end{aligned}
$$

Tensile Strength

Coefficient of Linear

Thermal Expansion

Heat Capacity

Thermal Conductivity

Permeability

\section{MES Units}

$2718.6 \mathrm{~kg} / \mathrm{m}^{3}$

$0.8 \%$

$1.5 \%$

$71.0 \mathrm{GP}$

0.25

$46.5 \mathrm{GPa}$

$28.66 \mathrm{~Pa}$

$282.1 \mathrm{MPa}$

6.97MPa

SOUCE: Office of haste Isolation, 1978

Less than $1 \times 10^{-8} \mathrm{~cm} / \mathrm{sec}$ 
would be the same as typical granites. On the other hand, they have been speclally selected because of their lack of jointing, lack of weathering, homogeneous nature, uniform coloring and texture and their proximity to the surface. Some of these quarries exhibit very high insitu stress fields. Table 1-10 (Ramspott, 1979) presents the comparison of rock properties from Climax stock at the Nevada test site and the St:ipa Mine in Sweden. Notice that for any particular site, the variation in properties is much smaller than the range established for a generic rock granite.

The most common test performed in rock mechanics work is the uniaxial compression test from which one can obtain Young's modulus (the ratio of stress to resultant strain) and Poisson's ratio (the ratio of lateral to longitudinal strain, Appendix A). At the edge of an underground opening the confining pressure is zero. As one progresses away from the opening, the stress state becomes triayial. The two minor principal stresses may or may not be equal. Figure 1-8 shows the effect of confining pressure on the stressstrain curve (Swan, 1978). Figure 1-9 depicts the variation of Young's modulus and fracture stress with confining pressure for Stripa granite (Swan, 1978), Notice that as the confining pressure is changed from 0 to about 30 $\mathrm{MPa}$, the modulus changes from approximately 70 to $80 \mathrm{GPa}$. Thus the variation over this range is of the order of $15 \%$. 
TABLE 1-10. Comparison of rock properties.

\begin{tabular}{|c|c|c|}
\hline Property & $\begin{array}{l}\text { Climax stock } \\
\text { quartz monzonite }\end{array}$ & $\begin{array}{l}\text { Stripa mine }{ }^{b} \\
\text { Swedish granite }\end{array}$ \\
\hline $\begin{array}{l}\text { Dry } \\
\text { density, } g / \mathrm{cm}^{3}\left(1 b / t t^{3}\right)\end{array}$ & $\begin{aligned} & 2.6-2.66 \\
: \quad & (163-166)\end{aligned}$ & $\begin{array}{l}2.6 \\
(163)\end{array}$ \\
\hline Porosity (6) & $0.7-1.1$ & 1.7 \\
\hline $\begin{array}{l}\text { Compressive } \\
\text { strength, } \mathbb{M P a}(p s i)\end{array}$ & $\begin{array}{l}210 \\
(30,500)\end{array}$ & $\begin{array}{l}217 \\
(31,500)\end{array}$ \\
\hline $\begin{array}{l}\text { Young's } \\
\text { modulue, GPa(psi) }\end{array}$ & $\begin{array}{l}61.4-69.7 \\
\left(8.9-10.1 \times 10^{6}\right)\end{array}$ & $\frac{51.3}{\left(7.4 \times 10^{6}\right)}$ \\
\hline Poisson's ratio & $0.21-0.22$ & 0.23 \\
\hline $\begin{array}{l}\text { Thersal } \\
\text { conductivity, } \therefore / \mathrm{mk}^{\mathrm{k}}\end{array}$ & 3.0 & 3.5 \\
\hline \multicolumn{3}{|c|}{ 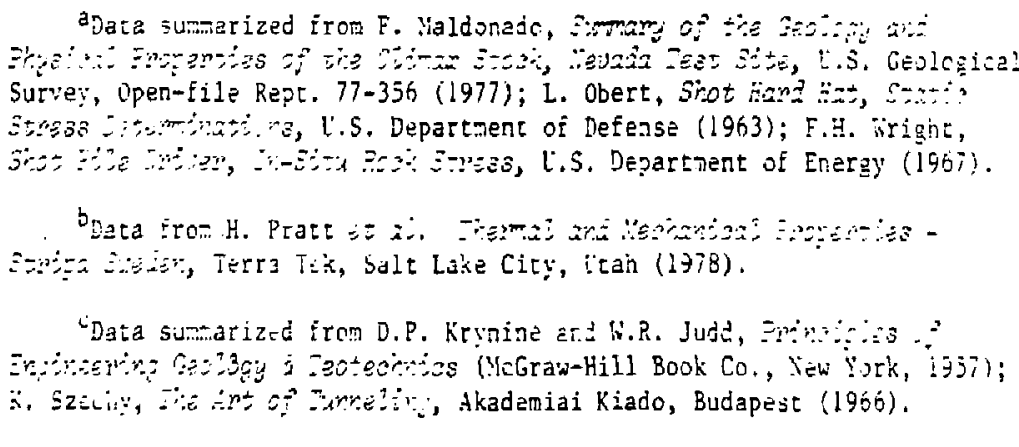 } \\
\hline
\end{tabular}

SOURCE: Ramspitt, 1979. 


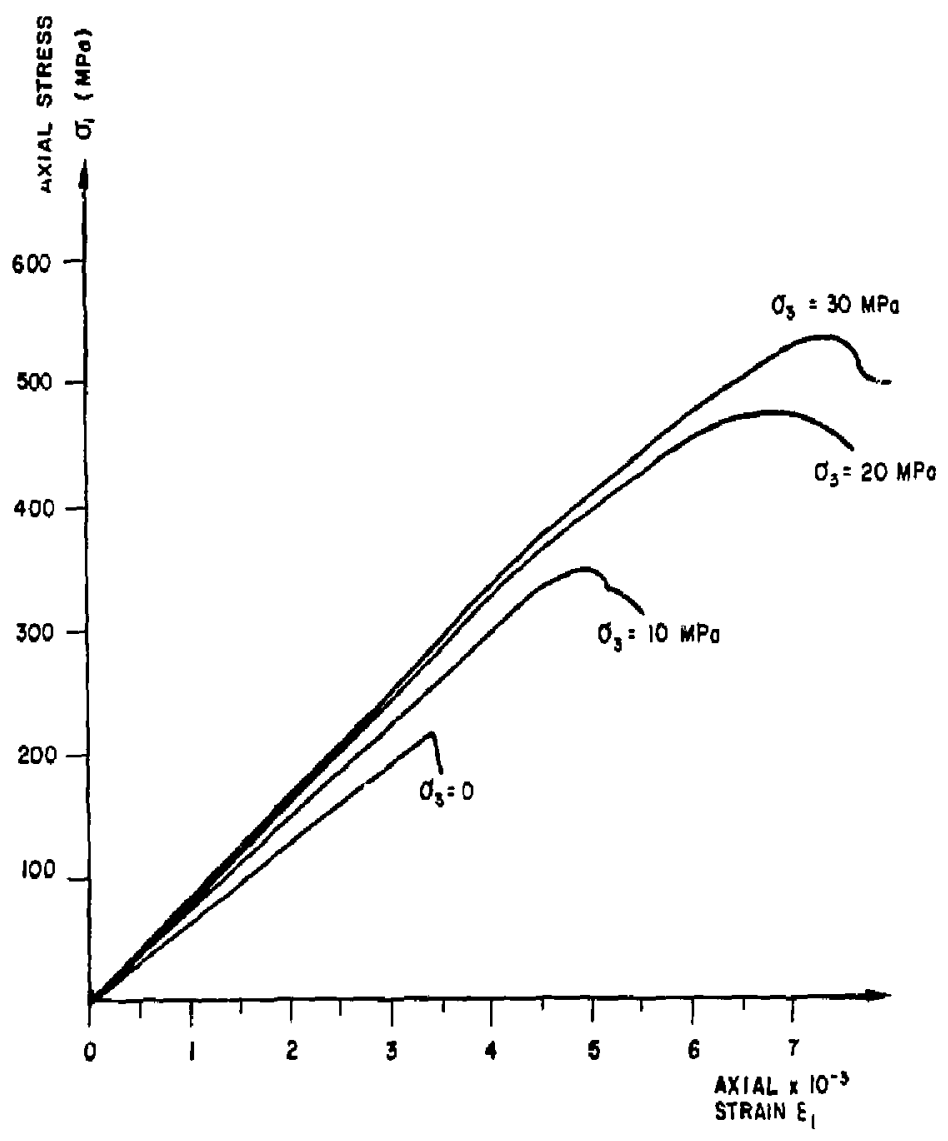

FIGURE 1-8 Axial stress versus scrain plots for confining pressures of $0,10,20$ and $30 \mathrm{MPa}$

Source: Swan, 1978. 


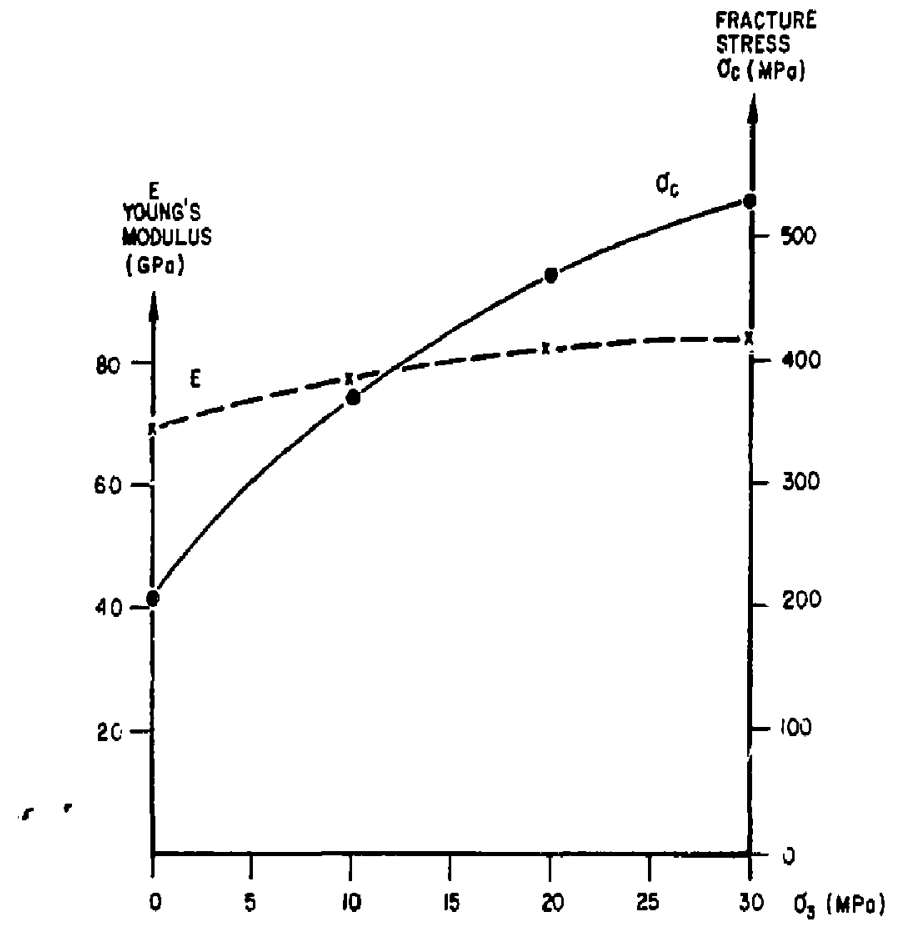

FIGURE 1-9 Graph showing variation of Young's modulus and fracture stress $\sigma_{c}$ with confining pressure Source: Swan, 1978. 
The compressive strength, on the other hand, varies from about $200 \mathrm{MPa}$ at 0 confining pressure up to about $550 \mathrm{MPa}$ at 30 MPa confining pressure. Therefore, al though the modulus is relatively insensitive, the compressive strength is very dependent upon the confining pressure.

Tensile strength, as determined in the laboratory, is very dependent upon the sample selection, the sample size, and the method used. It is obvious that samples with preexisting fractures, which would produce a tensile strength of 0 , are discarded prior to testing. An indirect way of determining tensile strength is the Brazilian test. It is also the easiest technique and the one most often employed. The results one obtains are of the order of 2 tines higher than one would obtain usirg a straight pull type of tension test. Yet both tests are supposedly measuring the same property. 


\subsection{THERMAL PROPERTIES}

When the surface of an underground opening is exposed to a heat source, transfer of heat will take place from the source to the rock mass by conduction, and possibly by radiation. Thermal transients, or a time-dependent temperature distribution, will be generated arross a heated zone in the rock around the opening. The temperature distribution is dependent upon a combination of three thermal properties--conductivity, density and specific heat. These properties can be characterized by a single thermal parameter known as diffusivity.

If an analytic solution to the temperature distribution is sought, one must essume that the rock mass is a contir.dum and that the thermal properties of the rock are independent of temperature and spacial location. If the temperatire dependence is considered, the problem becomes nonlinear, so nunerical methods nust be used. Such numerical techniques ara prescntly available, but the appropriate values of the thermal properties are lacking. The thermal variation for intact rock samples is generally rather high. In describing rock mass properties, the problem can become even more severe. If a piece of rock is free from constraint and heated uniformly, the stresses generated are 0 , even though 
the rock changes size due to thermal expansion. However, ir: a rock mass which is subjected to a temperature gradient, the state of thermally induced stress is not 0 . The change in stress is due both to geometric constraint and also to differences in the thermal expansion coefficients of the vario'ss constituents within the rock. These intergranular thermal stresses can develop independently of the existence of a thermal gradient or the geometric constraints described earlier. They can cause cracking along grain boundaries and also within the grains thenselves. Such cracking can significantly affect both the mechanical and thermal properties of the rock. As noted earlier, rock strength decreases with temperature whereas, in this particular case the stresses would be increasing. When the thermally-induced stress field is imposed upon the existing stress field that due to the insitu stresses, and the excavation-induced stresses), the total may exceed the strength of the rock.

Arother type of thermally-induced failure is spalling. This is a progressive failure induced by thermal shock or a sudden application of heat. Thermal loading of rock using the jet piercing system has been used for many years as a technigue for rock removal. Hence, for waste repository considerations, one must consider several types of thermal failure modes and have a very clear understanding of the thermal properties of the rock, on both a small and a large 
scale. These properties can vary widely between crystalline rock types, and even within the same rock type.

Thermal conductivity has been measured for many years. It is dependent upon both rock temperature and pressure. At present, there is very little data regarding the pressure dependency. The variation of thermal conductivity with temperature, however, is shown for various rocks in Figures 1-10 to 1-13 (Parsons et al, 1976; Thirumalai, 1970; Hasan, 1978; Mirkovich, 1968). Generally, a very rapid decrease in thermal condustivity occurs between $0^{\circ}$ and $250^{\circ} \mathrm{C}$. Thereafter, the rate of decrease is considerably slower. This lower temperature range is precisely that of most repositories, however. Note that there can be a rather large range at any ose particular temperature for a group of samples. This is shown in Table 1-11. For any one rock the variation is generally of the order of about $30 \%$, but can be as high as a factor of 2 .

As mentioned earlier, one of the factors that must be considered is the spallability of the rock, since this affects the conditions directly surrounding the bore hole. The plercing rating or spallability index of a number of different rocks is presented in Table' '12. The spallability or piercing index is based on a scale from 1-10, with 1 Indicating the greatest degree of spallability. Granites generally fall into the highest spallability category. 


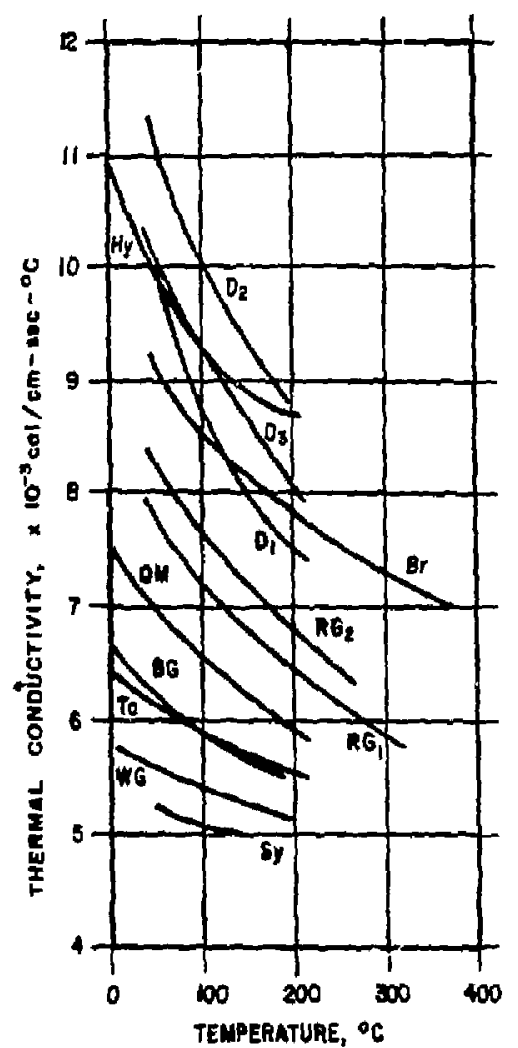

Sy 5yenite, Oribrio WG Wustorly Gronito

RG Roskport Stonite

To Tonolitt, Colilornio

BG Barte Sronite

Br Bromzitito

OM Quartz Monzonite, Colilornio

Hy Hyporsthonite

D Dunite

FIGURE 1-10 Variation of thermal conductivicy with temperature Source: $\mathrm{PBQ} \& D, 1976$. 

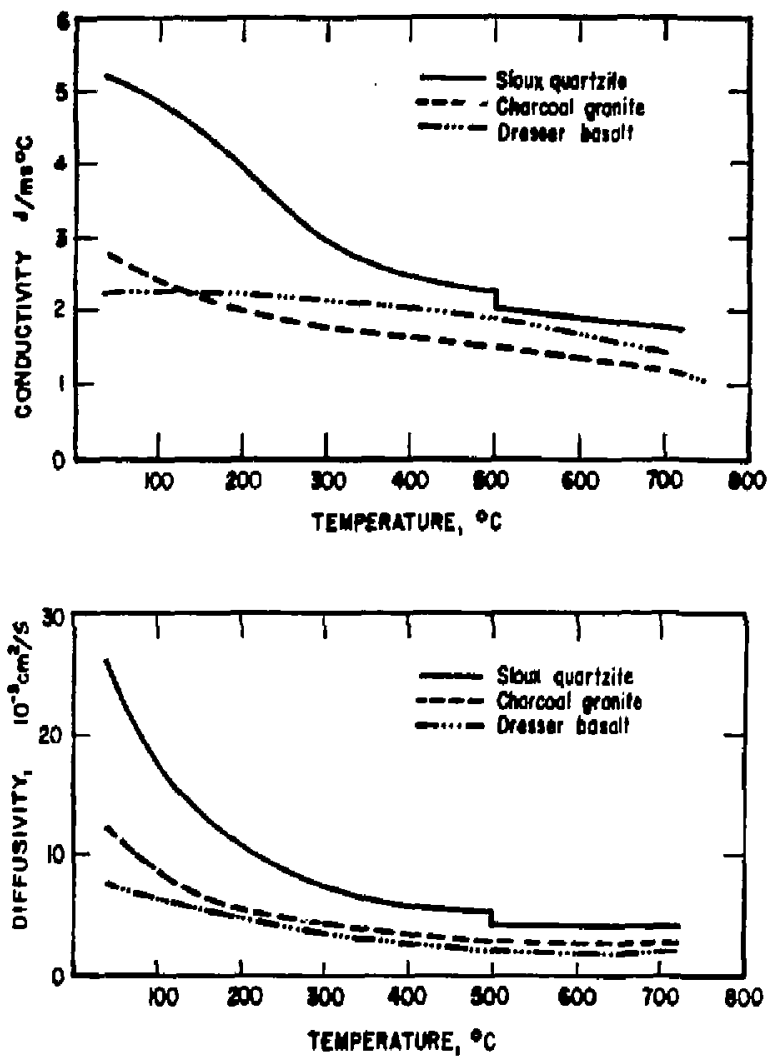

FIGURE 1-11 Varietion of thermal conductivity and diffusivity with temperature

Source: Thirumalai, 1970. 


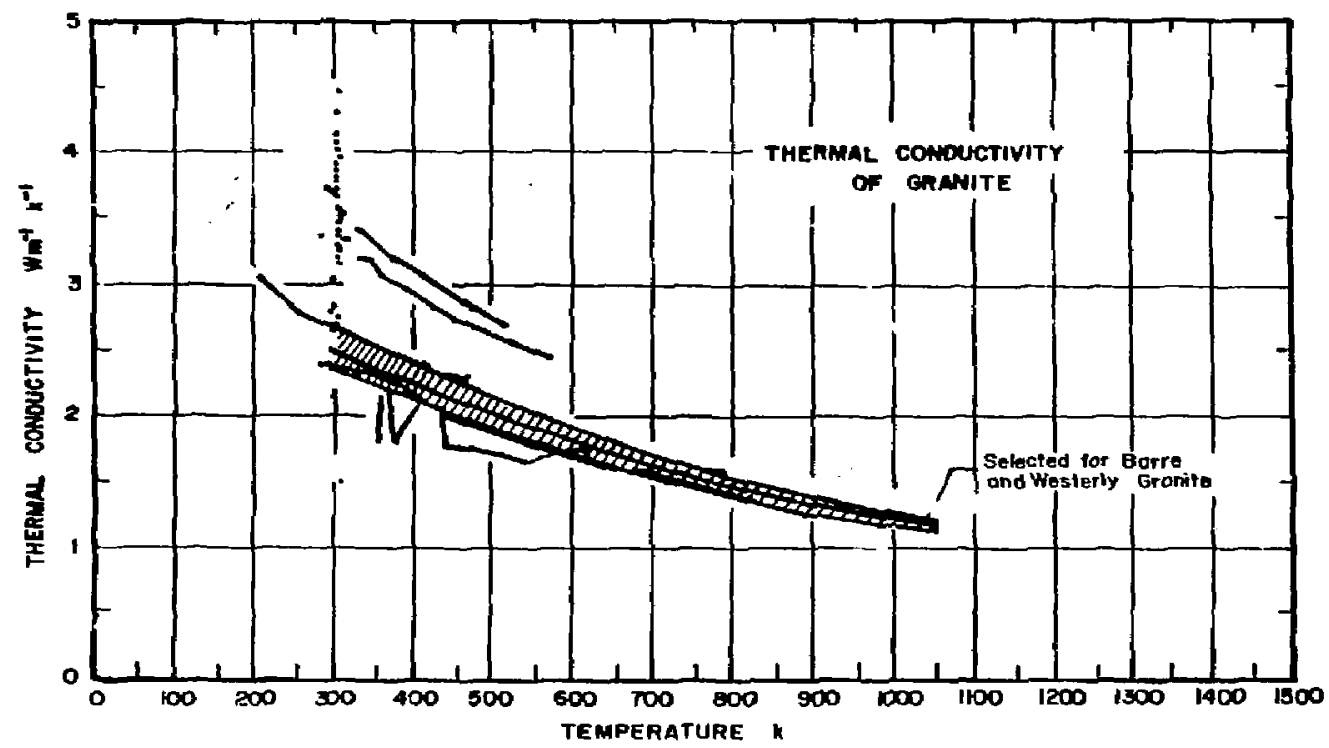

FIGURE 1-12 Variation of thermal conductivity with temperature So'trce: Hasan, 1978. 


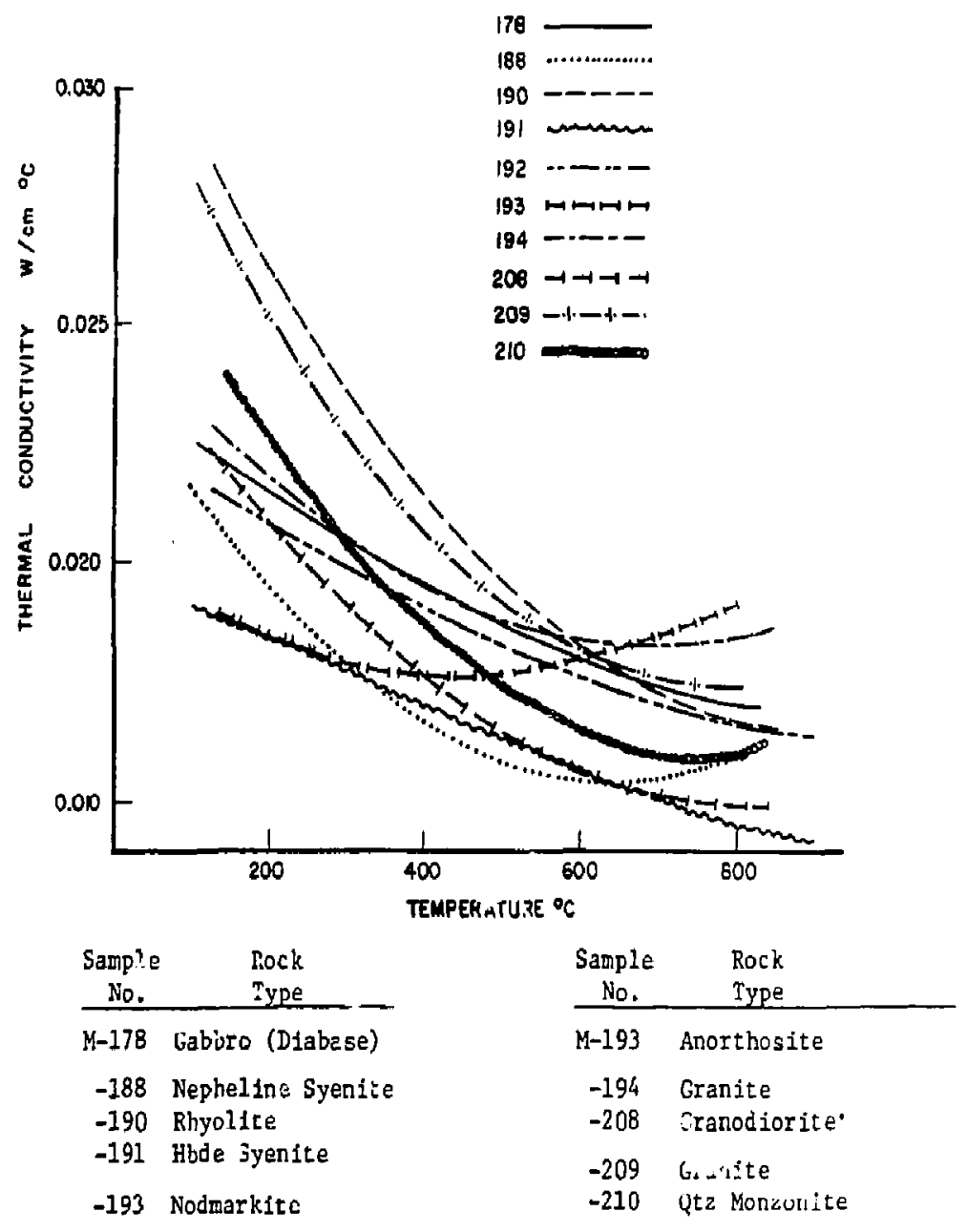

Figure 1-13 Thermal conductivity of selected igneous rocks Source: Mirkovich, 1968 
The measurements were made at a temperature of about $20^{\circ} \mathrm{C}$ unless ott $\mathrm{x}$ wise noted. The values are the means of groups of measurements. Only cases in which there are five or more measurements from a sing a Iithologic unit afe included. ( $\sigma=$ standard deviation.)

\begin{tabular}{|c|c|c|}
\hline ock Type and Locallty & $\begin{array}{l}\text { Number of } \\
\text { determin- } \\
\text { ations }\end{array}$ & $\begin{array}{l}\text { Conductivity } \\
\left(10^{-3} \mathrm{cal} / \mathrm{cos} \sec ^{\circ} \mathrm{C}\right) \\
\text { Mean }\end{array}$ \\
\hline hock bype ano, Locallity & detomb & \\
\hline
\end{tabular}

Granite and Quartz Monzonite Adams

Tunnel, Colorado

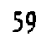

Granite, Loetschberg Tunnel Switzerland Granodiorite, Steamboat Springs, lie:ada Granodiorite, Grass Valley, Californla Quartz-Feldspar Porphyry, Jacoba Bore, Orange Free State, S. Africa $\left(25^{\circ} \mathrm{C}\right)$ Syenite and Syenite Porphyry, Kirkland Lake, Ontario

Altered Risolite, Timmins, Ontario

Norite, Sudbury, Ontari.

Serpentinized Periodotite, Thetford Mines, Cuejec

Agslomerate, Roodepoort Bore, Transval, S. Africa

Karao Dolerite, Kestell Bore, Oaräge Free State $\left(35^{\circ} \mathrm{C}\right)$

Ventersdorp Lava. Iscoba Bore, Orange Free State $\left(25^{\circ} \mathrm{C}\right)$

Ventersoro Lava, Roodepoort Bore, Transiral

Portage Lake Lava, Calumet, Mich., Dense Flows

daygdaloidal Tops

Porphyrite and Diabase, Grass Valley, CA

Quartz Diorite Gnelss, Adams Tunnel, CO

Injection Gnedss and scilist, ddams

Tunnel, Colorado

Gneiss, Cotthard Tunnel, Switzeriand

Gnelss, Simplon Tunnel, Suizerland, Perpendicular

Earallel

S1mpIon Tunnel, Switzerland,

Perpendicular

Parallel

Cnelss, Chester, Vesont, Perpendicular Paraliel

diphibolfte, Homestake MIr., Lead, S.D.,

Calcareous Yica Phyllite, Homestake Mine, Perpendicular

Parallel

Quartzite, Homestake Mine

Witwatersiand Quartzite, Gerhardminnebron Bore, Transvaal $\left(25^{\circ} \mathrm{C}\right) 17$

W1tvaterarand Quartzite, Roodepoort Boze, Transvasl

\begin{tabular}{|c|c|}
\hline $\begin{array}{l}7.39 \\
7.77 \\
6.64 \\
7.61\end{array}$ & $\begin{array}{l}6.7-8.6 \\
6.2-9.0 \\
6.2-5.9 \\
7.0-8.3\end{array}$ \\
\hline 8.0 & $7.6-8.6$ \\
\hline $\begin{array}{l}7.66 \\
8.23 \\
6.42\end{array}$ & $\begin{array}{l}5.3-9.5 \\
7.4-9.3 \\
5.5=7.3\end{array}$ \\
\hline 6.34 & $3.7-7.0$ \\
\hline 7.4 & $7.1-8.0$ \\
\hline 4.3 & $4.0-5.5$ \\
\hline 7.4 & $n . j-3.6$ \\
\hline $7 . ?$ & $3.2-3.7$ \\
\hline $\begin{array}{l}3.01 \\
6.5 \\
7.14 \\
7.75\end{array}$ & $\begin{array}{l}4.1-5.6 \\
5.5-9.0 \\
5.2-3.2 \\
5.3-3.5\end{array}$ \\
\hline $\begin{array}{l}7.74 \\
5.23\end{array}$ & $\begin{array}{l}4.9-i . j \\
3 . i-3.1 j\end{array}$ \\
\hline $\begin{array}{l}5.34 \\
3.90\end{array}$ & $\begin{array}{l}4.6-7.7 \\
6.0-11.4\end{array}$ \\
\hline
\end{tabular}

$$
4.1-5.3
$$




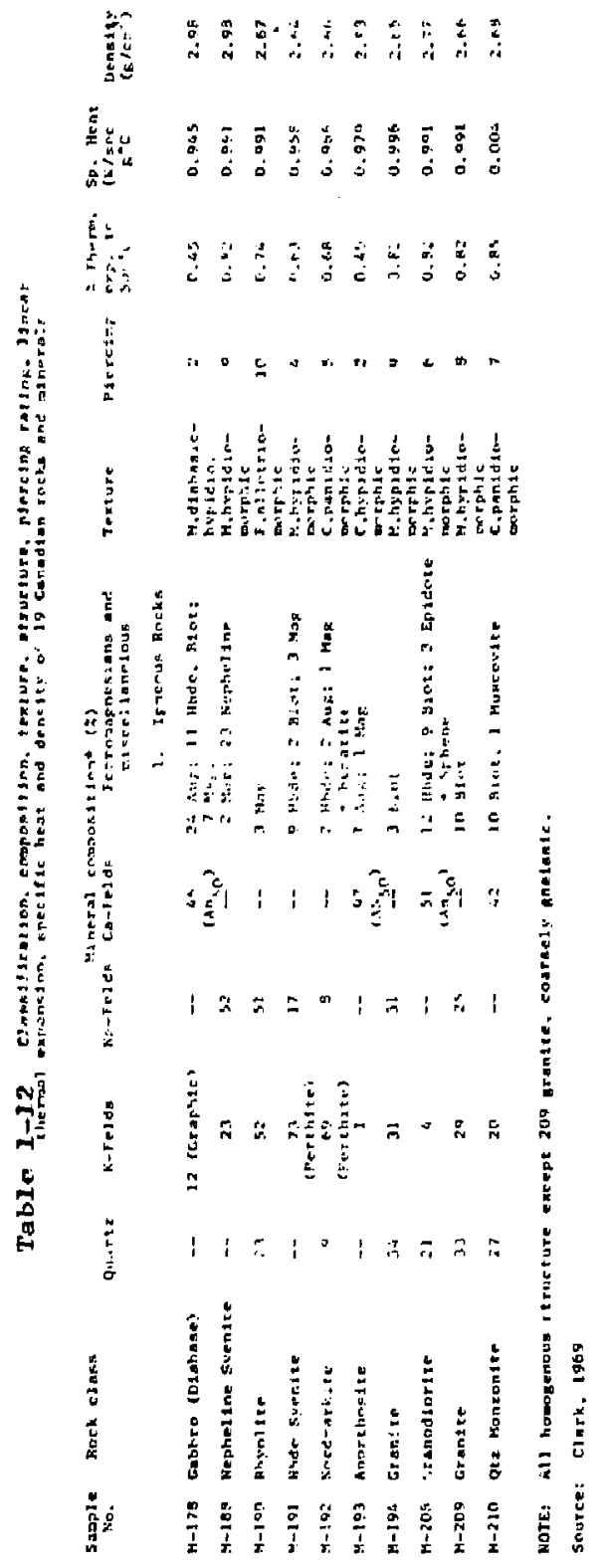


Specific heats of rocks are determined by heating specimens of known weights to a given temperature and then measuring the heit content of the rock by ialorimetric methods. Figure 1-14 shows the variation of specific heat with temperature for a number of different rock types. The rather strange behavior of quartz in the vicinity of $573^{\circ} \mathrm{C}$ is due to the transformation of quartz from the alpha to beta form. Note that over the temperature range shown in Figure 1-14, the variation in specific heat is approximately $25 \%$. Some additional values for mean specific heat values for the range of $25^{\circ}$ up to $625^{\circ} \mathrm{C}$ are given in rable 1-13.

The effect of temperaturf on density for relatively nonporous rocks such as granites, is negligible. For other rooks, however, the esnsity nay decrease with inceasing temperature as a result of moisture changes.

Thermal Aiffusivity is consiaered a derived and ty rhich inclules thernal conductivity, specific heat, ena density. The results gresented in rigures $1-15,1-16$ and $1-i 7$ reveal that the thermal diffusivity decreases with increasing temperature to at least $600^{\circ} \mathrm{C}$. Abcve this temperature, as shown in Figure 1-17, the diffusivity may increase 3 !ightly.

The fusion temperatures of the rock, which may or may not be appropriate for consideration in nuclear waste disposal, are 


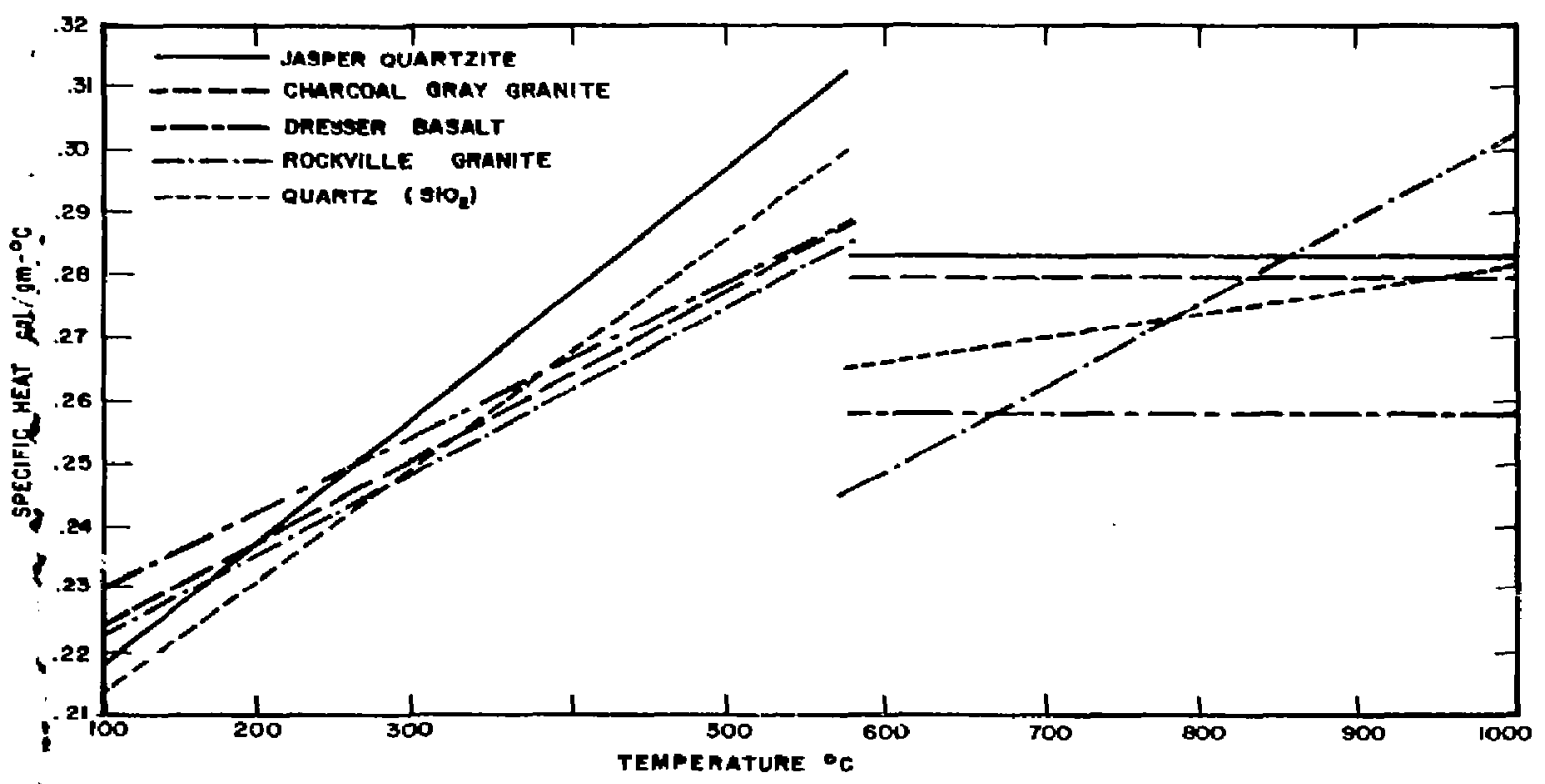

FIGURE 1-14 Variation of speciflc heat with temperature Source: PBQSD, 1976 and LIndroth and Krawza, 1971. 


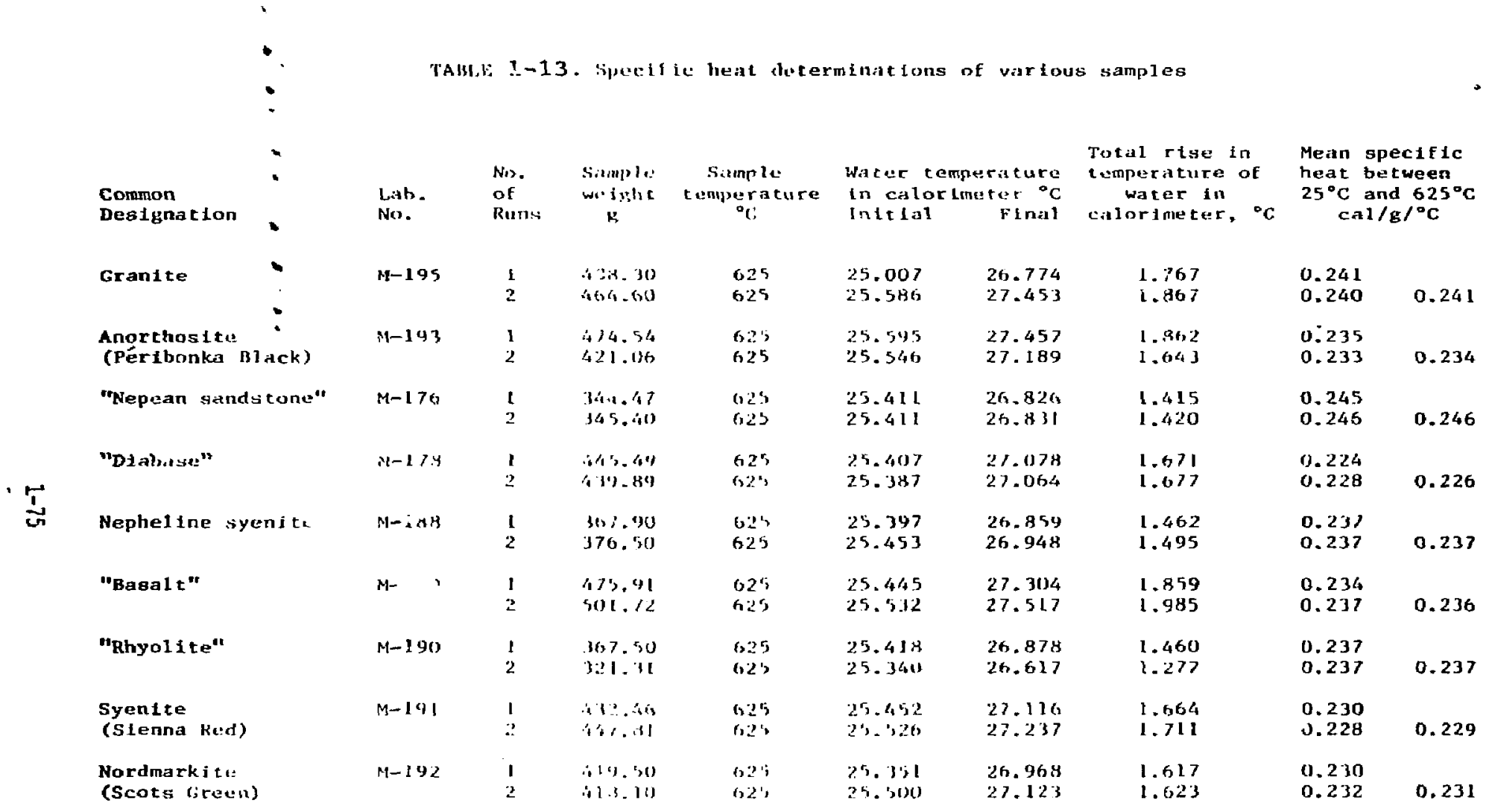

Source: Clark, I JE, 


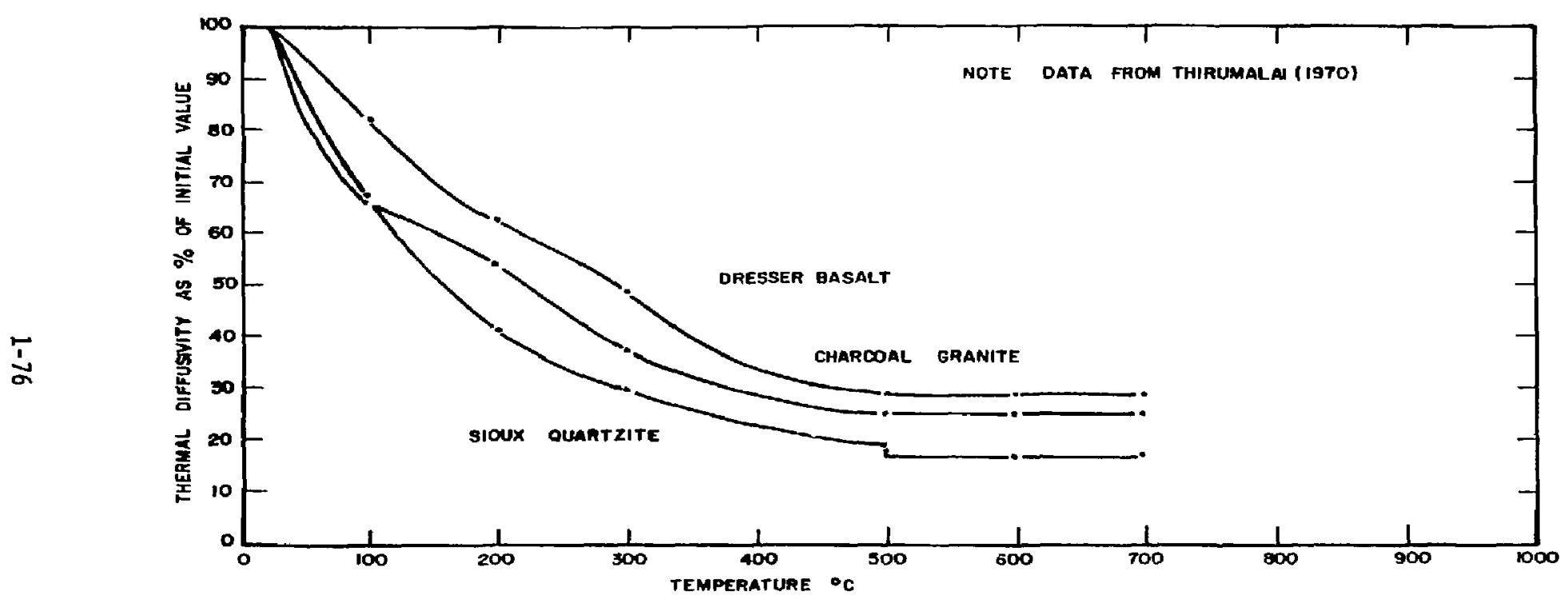

FIGURE 1-15 Varlation of normalized thermal diffusivity with temperature Source: Thirumalat, 1970. 


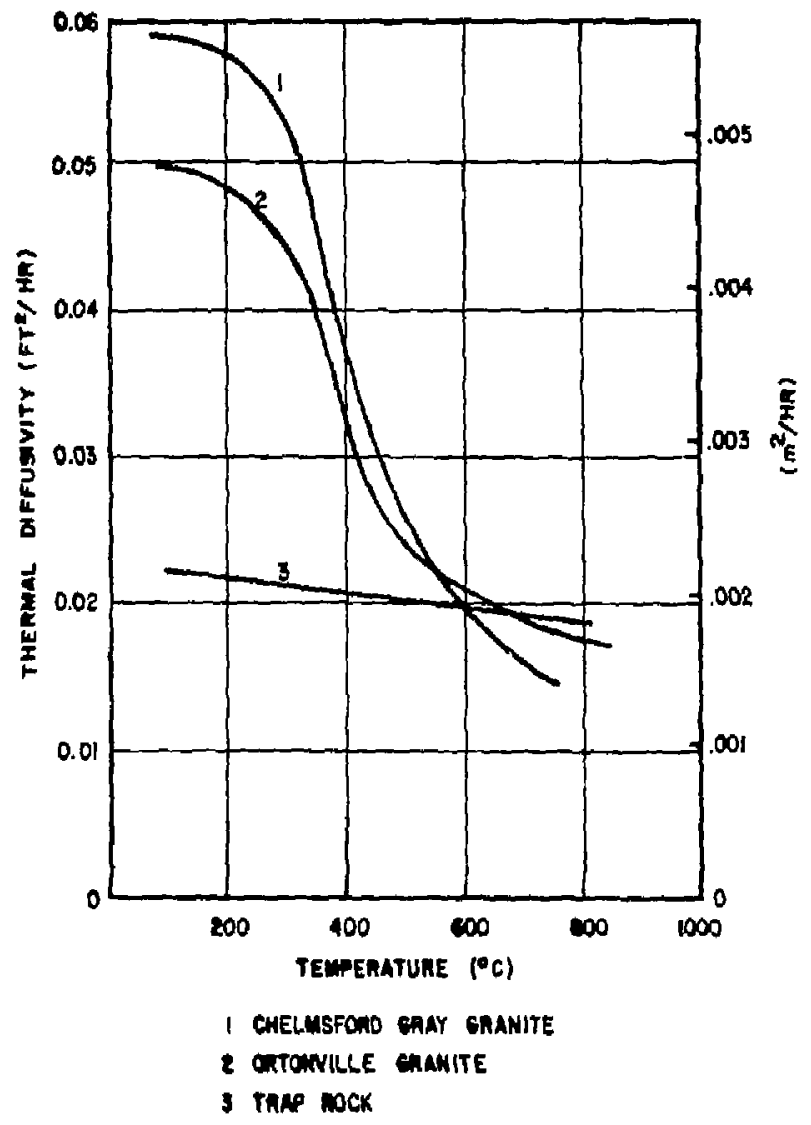

FIGURE 1-16 Variation of themal diffusivity with temperature

Source: Preeman et al, 1963. 

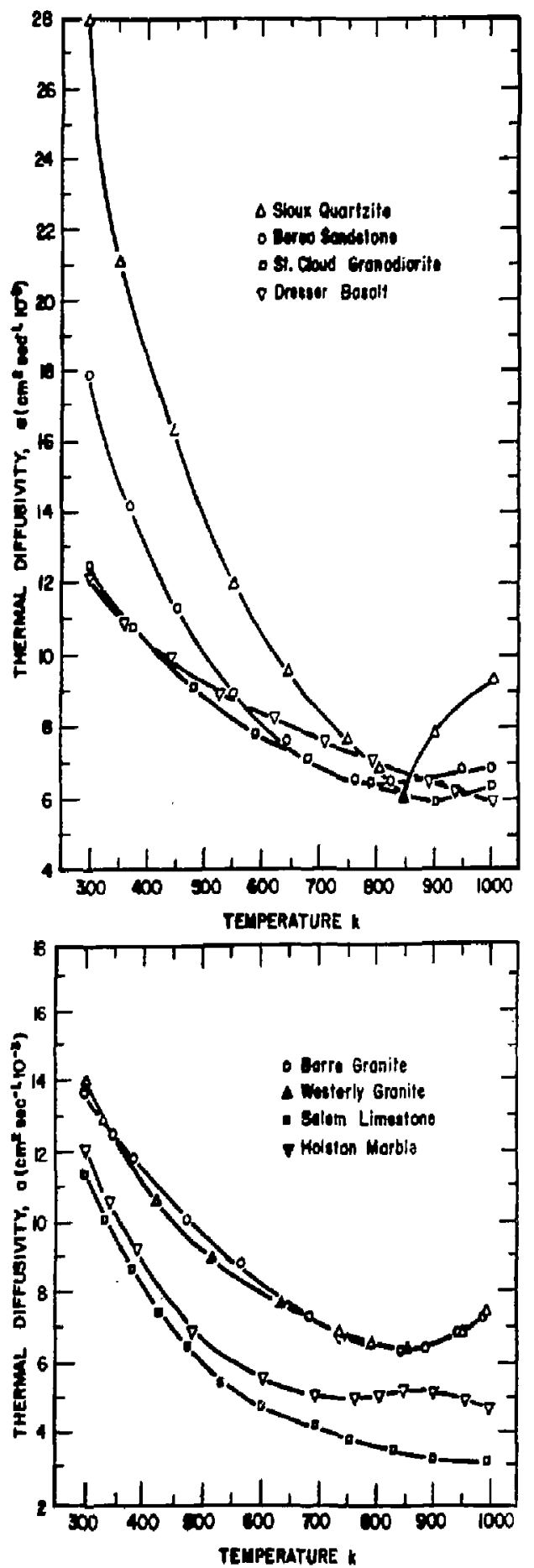

IIGURE 1-17 Thernal diffusivity of elght air-dried rocks as a function of cerperature Source: Hanley, 
shown in Tables 1-14, and 1-15. Notice that they are in the range of about $1,100^{\circ}$ to $1,300^{\circ} \mathrm{C}$, or well above the proposed operating temperatures for repositories. 
TAULE 1-14. Fuston temperatures of gertes " $\Lambda$ " rocks

Kork

Lab.

Commiso

Designation

No.

a. Crystalline Igneous Rock:s

M-143 Basalt (traprock)

$M-137$

M-135

M-149

M-155

$M-136$

$M-138$

$M-140$

b. $\quad M-151$

$M-154$

$M-157$

M-153

Basalt (traprock)
Uiabase trapruck

Medium red granfte

wite granite (high mical wotent)

Opalescent grantte

Grey grante

Grey grant te

Collins pink fratite

"Syenite

Red gramite

Mej rosic pirik grante

Granite gneiss

Grey grantite

Source:

Clark, 1969
Or1gin

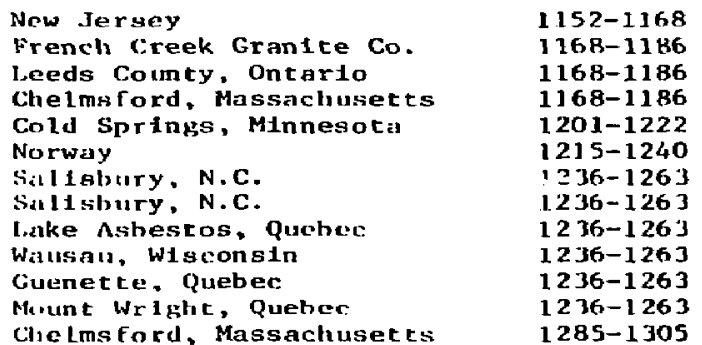

Fus 1 on

Temp.

Pyrometric

Cone

Equivalent

(P.C.E.) No. 
TABLE 1-15. Nus lol Lemperatures of serles "B" Jocks

Rinete

Lab.

No.
Common

Designation
Oristn
Fusion

Termp.

${ }^{\circ} \mathrm{C}$
Pyrometrie

Cone

Equivalent

(P.C.F.) No.

a. Crystalline tynewur Rncks

1. Quitez rieh (more thin $10 \%$ guirez)

$\mathrm{M}-195$

M-208 Granite

"Granfte" (blae.)

$\begin{array}{ll}M-210 & \text { "Granice" (Stanstead Grey) } \\ \text { H-209 } & \text { Granite (Saguenay Red) } \\ \text { M-194 } & \text { Grantce (Vernilion l'lnk) } \\ \text {-190 } & \text { "Whyol1te" }\end{array}$

a. Crystalline Ignewus Rocks

2. Quartz poor (1ess than $10 \%$ quartz)
"Basale"

"Diabitse"

Mnorthosite (Pertboned Blith)

Symite (Siennil Red)

Nordinarktte (Sx:uts circen)

Nepliejline syentice
Simslinal, Muebec

RIvieremalierre, Quebeo

Stans toad, Quebec

linke st. Jolun, Quebee

Vermition lay, Ontario

litvelock, Ontar1o

\section{Haveluck, Ontarto}

He $11^{t}$ s Corners, Ontario

Heribuncar River, Que;bed

Nilwcli Ife. Quebec

Mount Mropillt te, Queser.

Methen rowntibip. Ontarto
$1198-1221$

No resuits.

Al1 of the

test cones

bruke off.

$1201-1222$

$1177-2196$

$1207-1232$

$1215-1240$

C-6

$C-5$
$C-6$

$\begin{array}{ll}C-6 & 1 / 2 \\ C-7 & \end{array}$

$1149-1165$ $1164-1179$

$1297-1319$

1 ] $68-1186$

1 $167-1184$

$1168-1186$

Source: c1urk, 1069 


\subsection{THERMOELASTIC PROPERTIES}

The thermoelastic properties which will be discussed include the effect of temperature on strength, Young's modulus and Poisson's ratio, and on the linear coefficient of thermal expansion. Figure 1-18 shows a typical stress-strain plot for an uniaxial compression test conducted at $150^{\circ} \mathrm{C}$ on Stripa granite (Swan, 1978). Even at this elevated temperature, the relationship between stress and strain is still fairly linear. Figure $1-19$ shows the change in ul timate compressive strength with temperatures for a number of different rock types including four granites. The very severe decrease which occurs at about $1,100^{\circ} \mathrm{C}$ is due to reaching fusion temperature for these rocks. Otherwise, over the temperature range of principal interest (from $20^{\circ}$ to $400^{\circ} \mathrm{C}$ ) the decrease in strength varies depending on the rock, from $0 \%$ to approximately $50 \%$.

Figures 1-20 and 1-21 show the change in compressive strength with temperature and confining pressure. These tests have all been done with a confine pressure of 5 kilobars. Note that for the granite shown in Figure 1-20, the decrease over the temperature range of $0^{\circ}$ to $400^{\circ} \mathrm{C}$ is relatively small. In Figure 1-21, the deviatoric stress $\left(\sigma_{3}-\sigma_{3}\right)$ is plotted as a function of strain. With increasing temperatures at this pressure of 5 kilobars, the rocks 


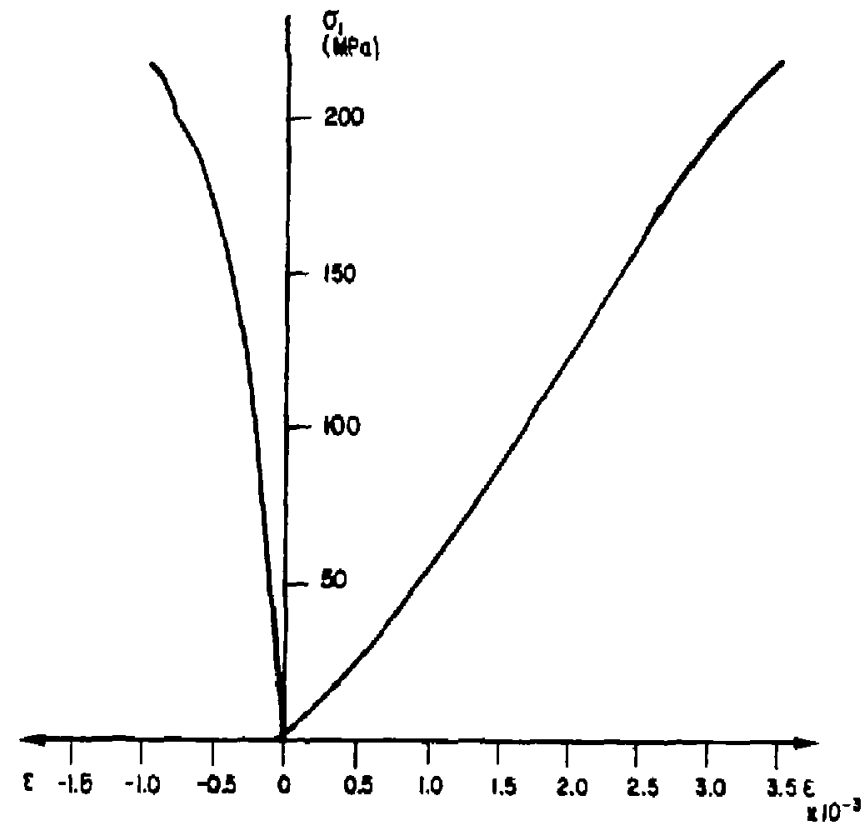

FIGURE 1-18 Typical stress vs otrafn plot from untaxial test at $150^{\circ}$ C. Source: Swan and Graham, 1978. 


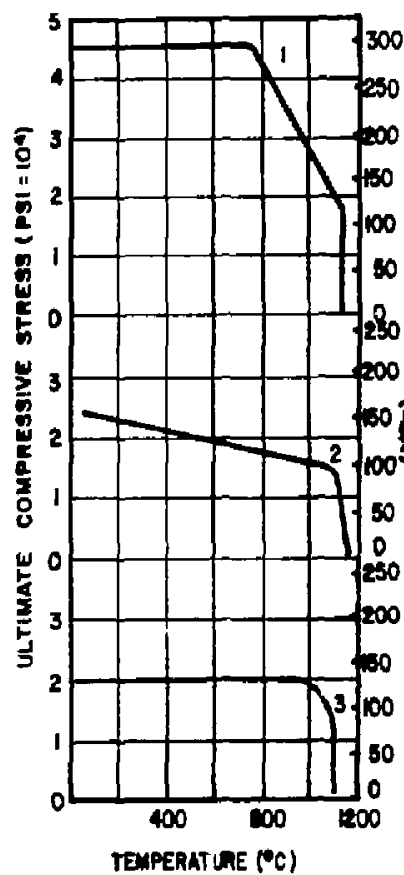

I FREKCH CNEEK CWNITE

2 SWENSOH PAK DUNITE 3 TRAP ROCK

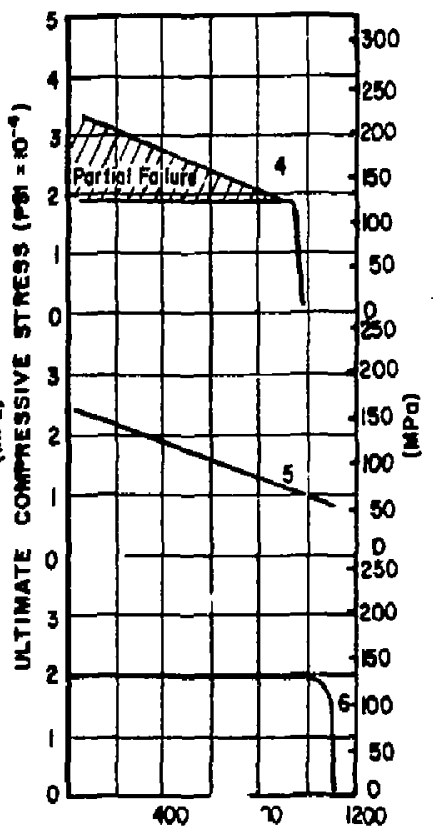

TEMPEK. RE $\left({ }^{\circ} \mathrm{C}\right)$

- SCOTSTOWN GRANITE

5 ORTONVILLE GRANITE

6 EMERALO PEARL

FIGURE 1-19 Variation of ultimate compressive atregs with temperature

Source: Freeman et al, 1963. 


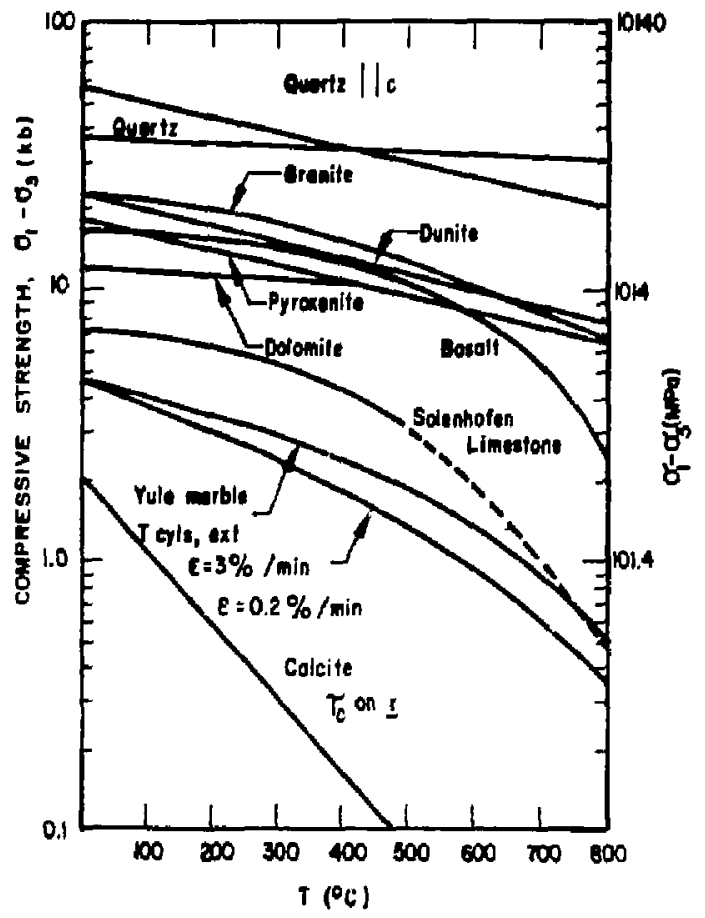

FIGURE 1- 20 strength of rocks and minerals at $5 \mathrm{~kb}$ Source: Griggs et al, 1960. 


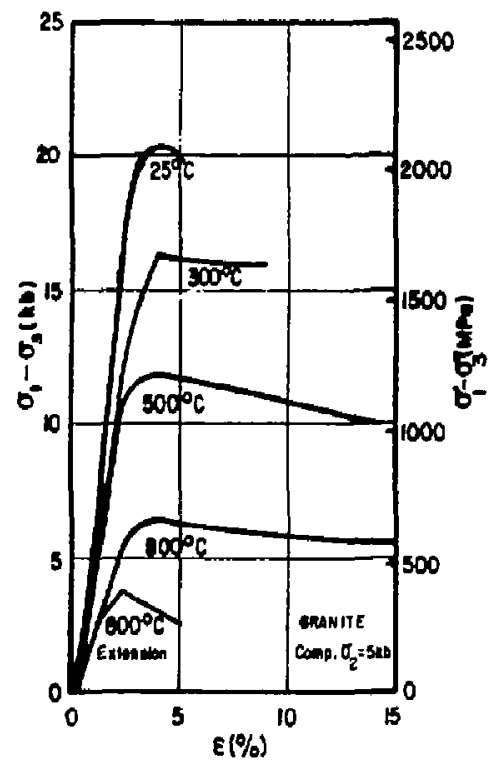

FIGURE 1-21 Ef fect of temperature on stress-strain curves for rocks Source: Griggs et a1, 1960. 
become much more plastic and the deviatoric stress reguired to cause extension is much smaller.

Figures 1-22 and 1-23 show Young's modulus and Poisson's ratio as a function of temperature for stripa granite. The error bars indicate $90 \%$ confidence limits for these laboratory tests. Notice that over the temperature range of $0^{\circ}$ to $200^{\circ} \mathrm{C}$, Yourg's modulus has decreased by approximately 308. For the same temperature range, Poisson's ratio has decreased to about half. The variation of young's modulus, shear modulus, and Poisson's ratio with temperature is shown for four rock types in Figure 1-24. Note that Young's modulus for charcoal granite is reduced by about a factor of 2, when going from room temperature to $400^{\circ} \mathrm{C}$. Po:sson's ratio would appear to change from positive to negative, which is rather unusual. It is clear that on-going work will help to clarify sone of these relytionships. In general, both the uniaxial and triaxial corpressive strengths of granite decrease markediy with increased semperature. 3oth the elastic modulus and Poisson's ratio are reduced.

The coefficient of linear thermal expansion is very important for the calculation of both the displacements and the stresses that will result from the thermal field. The 


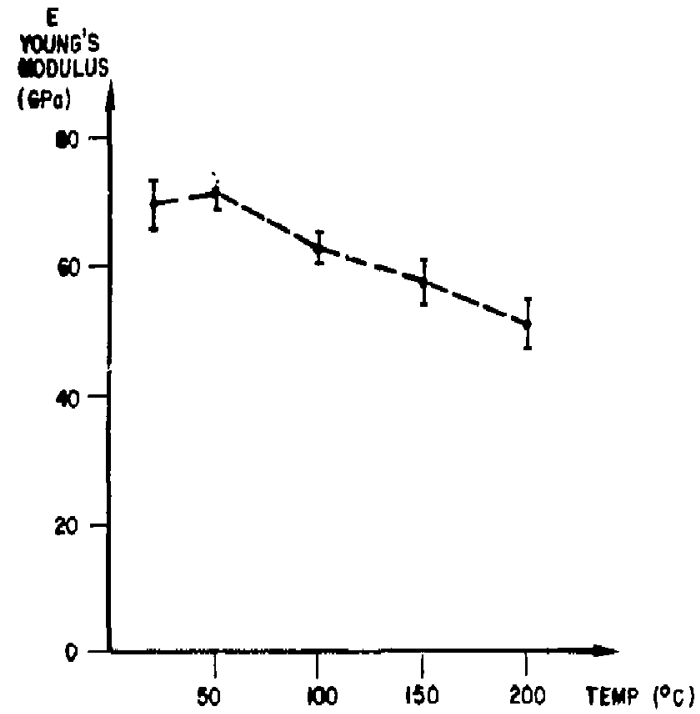

FIGURE 1-22 Young's modulus versus temperature showing $90 \%$ confidence limits Source: Swan, 1978.

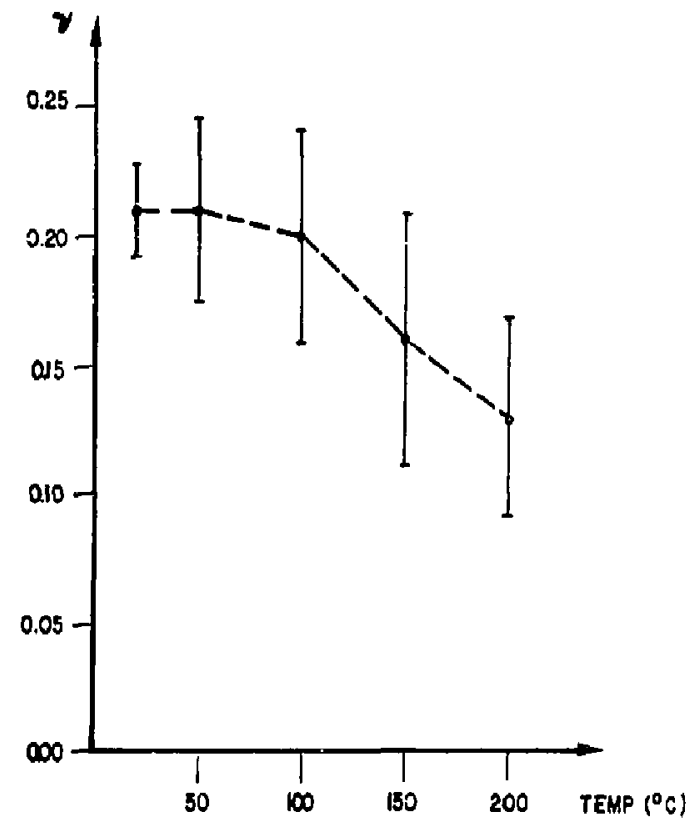

FIGURE 1-23 Poisson's ratio vere's temperature showing 90\% confldence limits Source: Swan, 1978. 

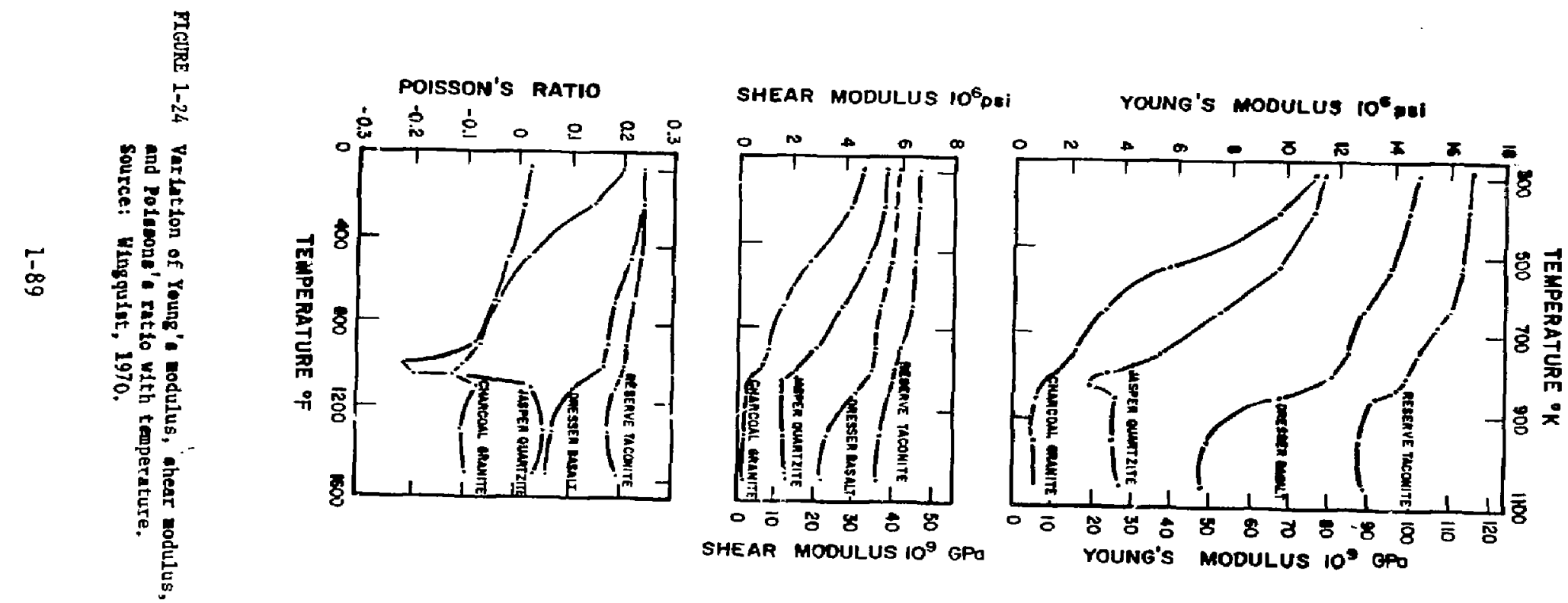
degree of temperature dependence of themal expansion varies widely among different rocks as shown in Figures 1-25, 1-26 and in Table 1-16. For example, the coefficient of linear expansion for charcoal granite is about 8 times that at $200^{\circ} \mathrm{C}$ as it is at $424^{\circ} \mathrm{C}$. This parameter is also affected by the alpha-beta inversion temperature $\left(573^{\circ} \mathrm{C}\right)$ of quart2, illustrated in Figure 1-26.

It is interesting to note from Table $1-16$ that the values for most granites or granite-type rocks are relatively similar over a wide tenperature range.

The variation in percent volume expansion for some comnon igneous minerals shown in Figure 1-27 illustrates why guartz is so effective in causing thermal stresses in high quartz content rocks, such as igneous rocks. This aifference in vlume expansion is expisited in thermal types of rock removal processes. The average linear expansion of rocks (Table 1-17) having excel?ent and very good spallzillity is showi in Figures 1-28 and 1-29, as a function oz temperature. Most granitic rocks have a very good spallability and, therefore, would be expected to spall under high thermal gradients.

Table 1-18 shows the effect of the combination of heat and moisture on the strength of granite. Note that when granite 


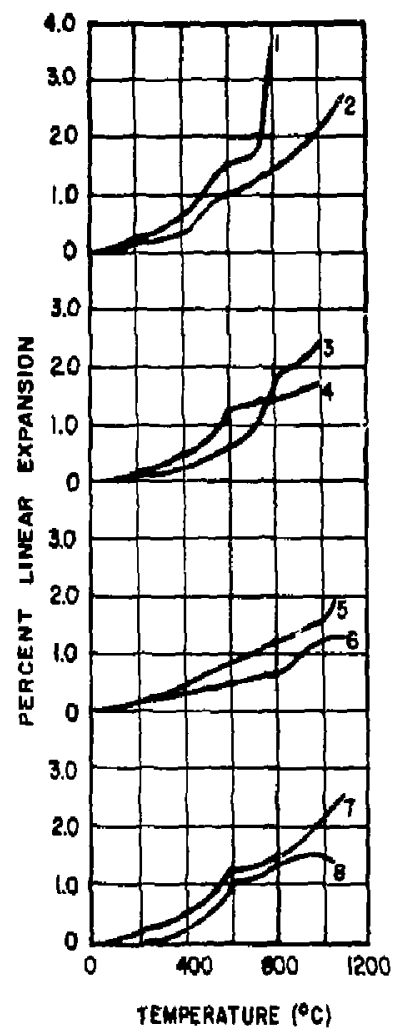

I GHELMSFORD WHITE GRAMITE 2 SYENITE P.P.

3 WOOOLEAF GRANITE

1 OPALESCENT GRANITE

5 emeralo pearl

- TRAP ROCK

7 SCOTSTOWN GRANITE

- Minhesotalte

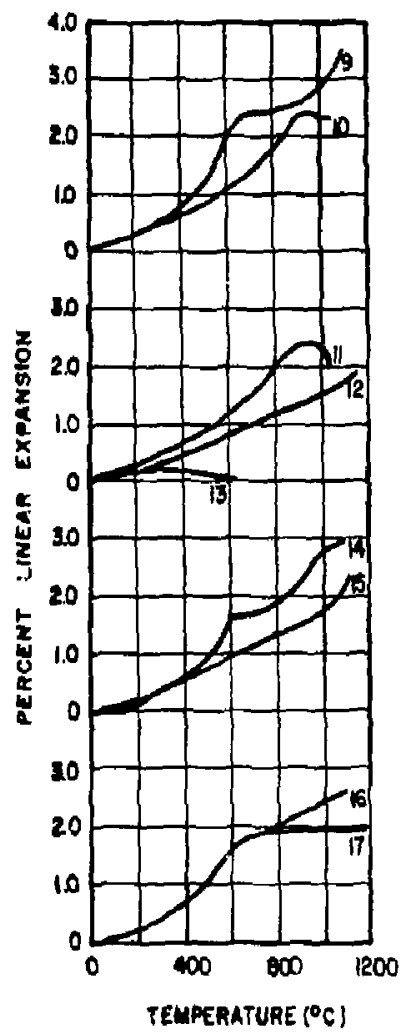

- SWENSON PINK gRANITE 10 DOLOHITE

II LIMESTONE

I2 FRENCH CREEK GRANITE

13 SERPENTINE

14 CHELMSFORD GRAY GRANITE

IS SYENITE, OOCO PIERCING

I6 CRTOWVILLE GRANITE

IT OUARTZITE

FIGURE 1-25 Variation of linear thermal expansfon with temperature Source: Freeman et a1, 1963. 


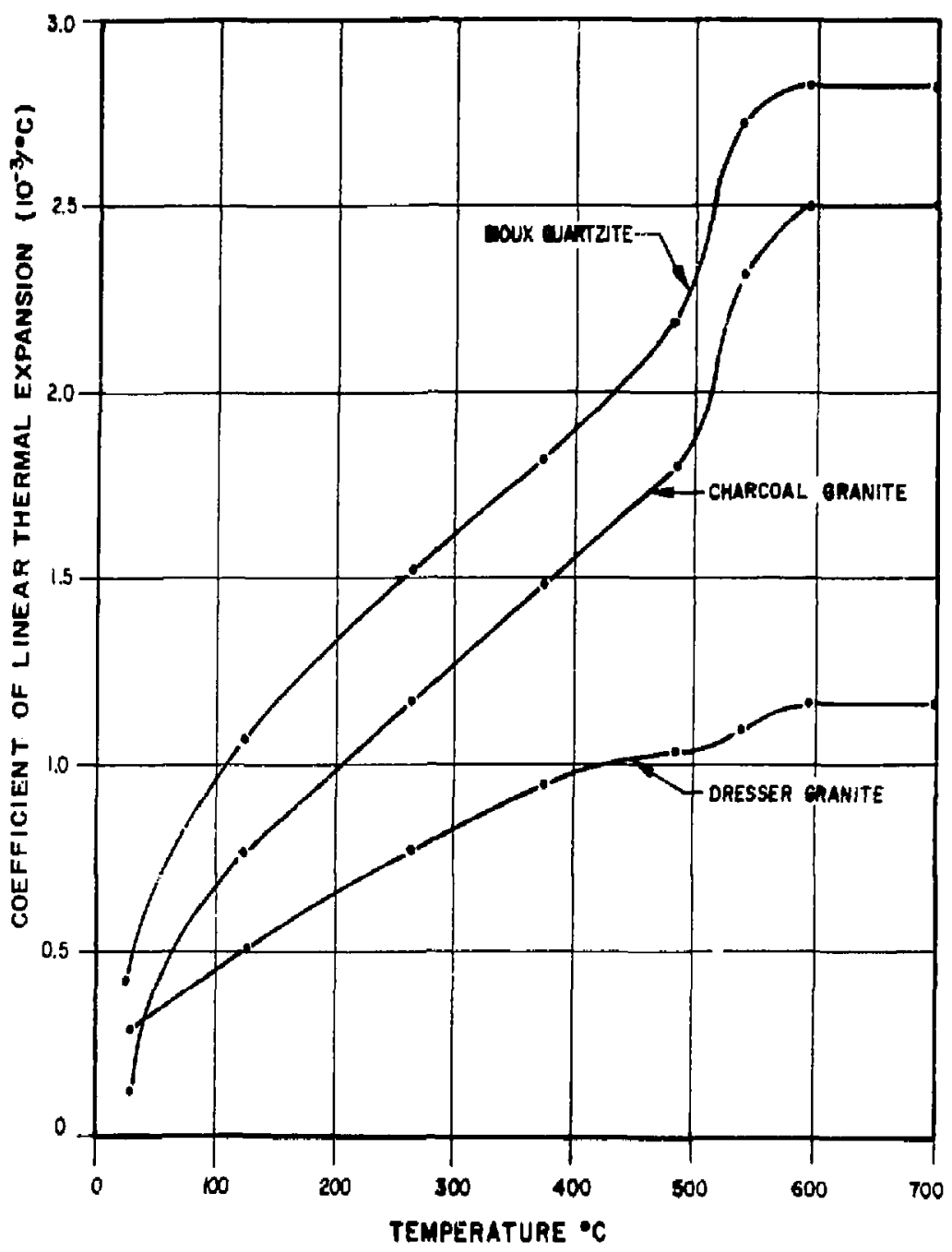

FIGU'E 1-26 Variation of coefficient of linear thermal expansion with temperature. Source: Lehnhoff and Scheller, 1975. 
TABLE 1-16. Measured coefficients of themal expansion.

\begin{tabular}{|c|c|c|c|}
\hline Rock type & $\begin{array}{l}\text { Specimen } \\
\text { No }\end{array}$ & $a_{v}\left(25^{\circ} \mathrm{C}\right) \times 10^{-6}$ & $a_{v}\left(400^{\circ} \mathrm{C}\right) \times 10^{-6}$ \\
\hline & & $\begin{array}{l}\text { Experiment } \\
\text { Ref. [1] }\end{array}$ & $\begin{array}{l}\text { Experimers } \\
\text { Ref. [1] }\end{array}$ \\
\hline $\begin{array}{l}\text { Chelms ford } \\
\text { sranite }\end{array}$ & A757 & 21.5 & 73,3 \\
\hline $\begin{array}{l}\text { Yesterly } \\
\text { granite }\end{array}$ & 1134 & 24.8 & 67.0 \\
\hline $\begin{array}{l}\text { Veusau } \\
\text { granite }\end{array}$ & 1343 & 19.9 & 71.5 \\
\hline $\begin{array}{l}\text { Graniteville } \\
\text { granite }\end{array}$ & 1410 & 25.1 & 70.3 \\
\hline $\begin{array}{l}\text { Red 3iver } \\
\text { Quertzmor. }\end{array}$ & 1370 & 21.1 & 35.3 \\
\hline
\end{tabular}

SoizCE: Sxan, 1978. 


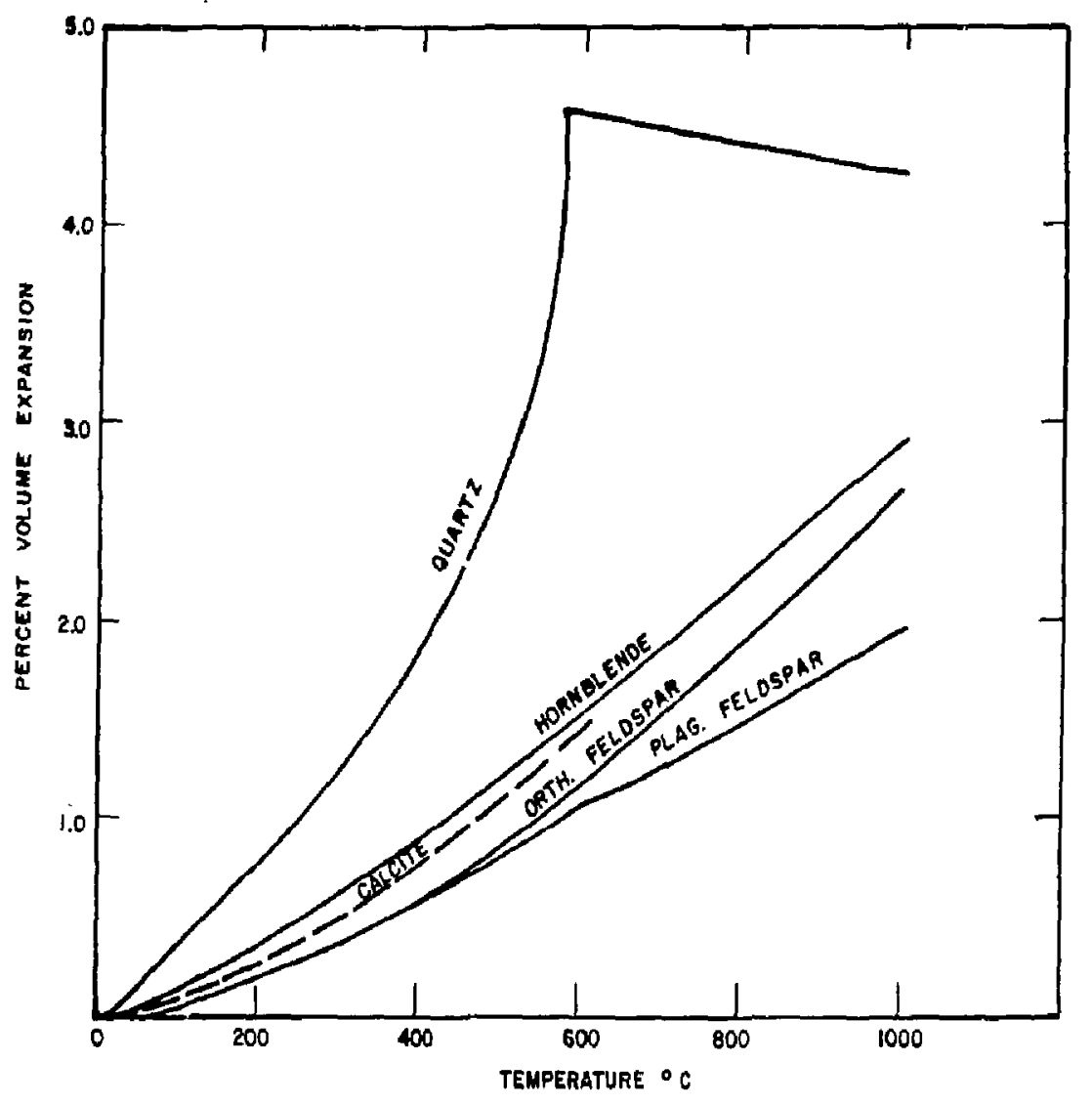

FIGLRE 1-27 Volume therms 1 expansion of some common minerals Source: Skinner, 1966. 
TABLE 1-17. Mineralogical composition of rocks vs. rock-rettoval rate and percent elongation at $600^{\circ} \mathrm{C}$

A. CRYSTALLINE IGNEOUS ROCKS

\section{Quartz-rtch Rocks-( $10 z$ Quartz)}

$\begin{array}{lcccccc}\text { Rock Class. } & \text { Granite } \\ \text { Rock Sample } & \text { M-195 } & \begin{array}{c}\text { Granodiorite } \\ \text { M-208 }\end{array} & \begin{array}{c}\text { Quartz } \\ \text { Monzonite } \\ \text { M-210 }\end{array} & \begin{array}{c}\text { Granite } \\ \text { M-209 }\end{array} & \begin{array}{c}\text { Granite } \\ \text { M-194 }\end{array} & \begin{array}{c}\text { Graphic } \\ \text { Granite } \\ \text { M-190 }\end{array} \\ \text { I K-Feldspar } & 21.2 & 3.8 & 19.5 & 28.6 & 31.1 & 51.5 \\ \text { 2 Plagioclase } & 44.8 & 50.5 & 41.4 & 23.0 & 31.3 & 20.5 \\ \text { Perthite } & - & - & - & 2.4 & 0.9 & (70 \%) \\ \text { Quartz } & 29.3 & 20.6 & 27.4 & 33.5 & 32.8 & 23.2 \\ \text { Amphibole } & 0.1 & 12.0 & - & - & - & 0.1 \\ \text { Other Yaftcs } & - & 2.0 & 0.3 & 0.6 & 0.4 & 0.5 \\ \text { Biotite } & 1.9 & 9.4 & 9.9 & 9.8 & 2.9 & 1.0 \\ \text { Muscovite } & 1.7 & - & 1.1 & 0.3 & 0.1 & 0.6 \\ \text { Magnetite } & - & - & 0.3 & - & 0.3 & 2.5 \\ \text { Carbonate } & - & - & 0.1 & 0.3 & - & - \\ \text { Others } & - & 1.7 & - & 1.5 & 0.2 & -\end{array}$

\section{Rock-removal}

Rate (cu In.)

cu ft $0_{2}$ )

$1 . n$

1.5

2.4

3.1

3.1

3.4

7o Elongation at $600^{\circ} \mathrm{C}$
1.4
2.0

1.4

$1.5 \quad 1.6 \quad \therefore .5$

2. Quartz-poor Rocks ( $10 \%$ Quartz)

\begin{tabular}{|c|c|c|c|c|c|c|}
\hline $\begin{array}{l}\text { Rock Class, } \\
\text { Rock Sample }\end{array}$ & $\begin{array}{c}\text { Basalt } \\
\text { (Saussu- } \\
\text { t1te) } \\
y=139\end{array}$ & $\begin{array}{c}\text { Cabbro } \\
\text { (Diabase) } \\
\text { Y-179 }\end{array}$ & $\begin{array}{l}\text { Anortho- } \\
\text { os } 1 \text { te } \\
M-193\end{array}$ & $\begin{array}{l}\text { Syenite } \\
M=19 !\end{array}$ & $\begin{array}{c}\text { Nerd- } \\
\text { markite } \\
y-192\end{array}$ & $\begin{array}{c}\text { Yeph. } \\
\text { Syinite } \\
1-193\end{array}$ \\
\hline $1_{\mathrm{K}-\mathrm{Fe}} \mathrm{ldspar}$ & - & 6.0 & 0.5 & - & - & 23.3 \\
\hline $2_{\text {Perthita }}^{\text {Platase }}$ & 17.8 & 46.2 & 98.0 & 17.4 & 7.5 & 52.3 \\
\hline Nepheline & $=$ & - & - & 69.2 & 73.3 & - \\
\hline Quartz & $5(?)$ & 6.2 & - & - & $\therefore$ & 23.0 \\
\hline Pyroxene & 19.7 & 23.8 & 1.0 & - & 9.4 & - \\
\hline Amphibo'e & - & 5.0 & 0.3 & 8.8 & 1.8 & - \\
\hline Other $\mathrm{X}_{\text {afics }}$ & 52.1 & 4.9 & 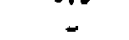 & 8.8 & 6.7 & - \\
\hline Blotite & - & 1.0 & 0.2 & -3 & - & - \\
\hline Yuscovite & - & - & 0.2 & 2.3 & 0.1 & - \\
\hline Magnetite, Hem. & 5.2 & 6.9 & 0.2 & 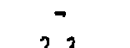 & - & 0.2 \\
\hline Carbonate & 0.2 & - & -2 & 2.3 & 1.1 & 1.5 \\
\hline \multirow{2}{*}{\multicolumn{7}{|c|}{$\begin{array}{l}\text { Rack-removal } \\
\text { Rate (cu } \mathrm{in}, / \\
\left.\text { cu ft } \mathrm{O}_{2}\right)\end{array}$}} \\
\hline & 0.4 & 0.6 & 1.0 & 1.5 & 2.0 & 3.9 \\
\hline $\begin{array}{l}\text { 7 Elongation } \\
\text { at } 600^{\circ} \mathrm{C}\end{array}$ & 0.5 & 0.75 & 0.55 & 0.82 & & \\
\hline TES: ${ }_{2}^{1}$ Inel & & & & & 1.0 & 1.13 \\
\hline
\end{tabular}

SOURCES: Clask, et 1,1970 . Geller, et $11,1962$. 


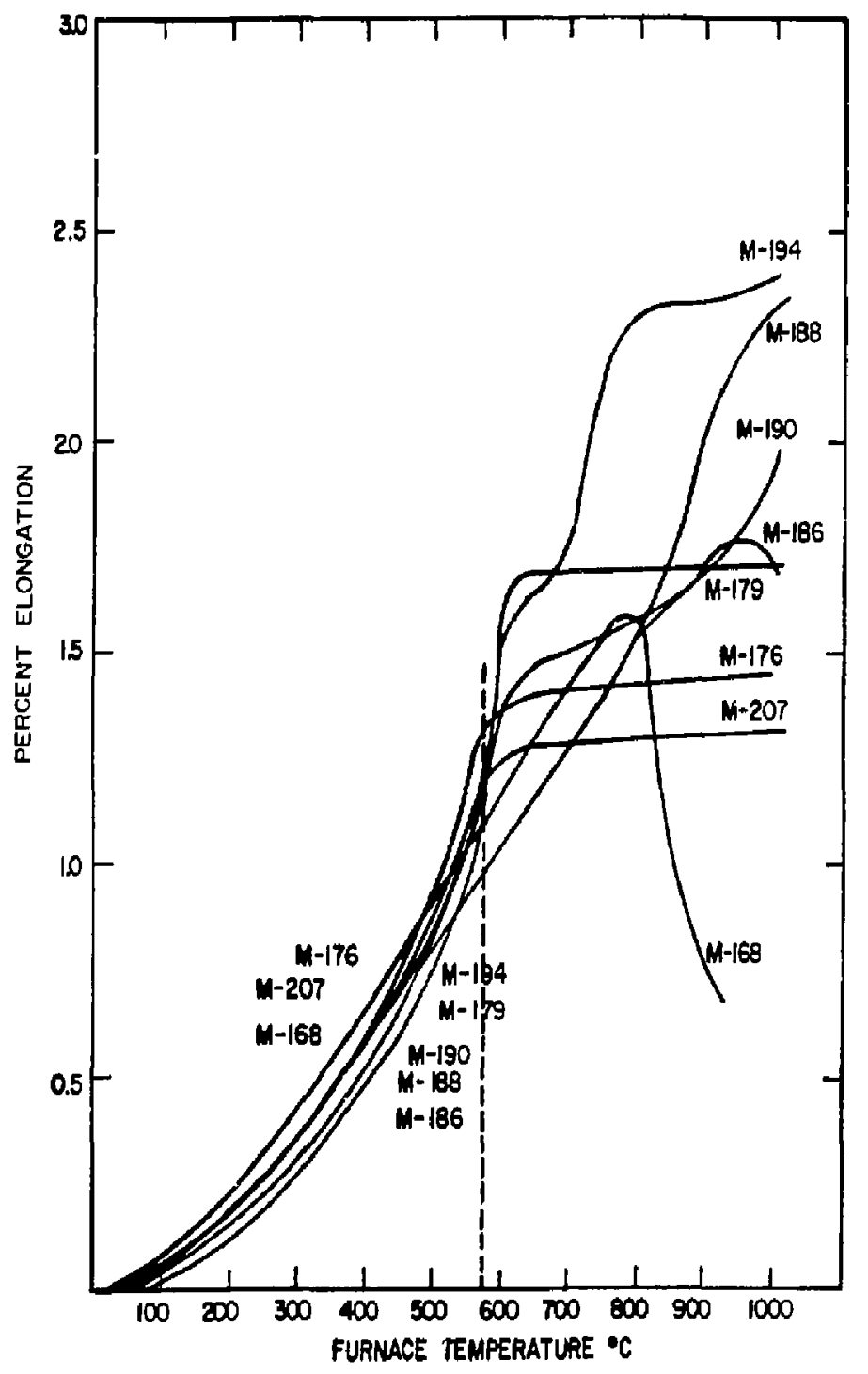

FIGURE 1-28 Average 11near expansion of rocks of excellent and very good plerceability

Source: Clark et 21,1969 and Geller et a1, 1962. 


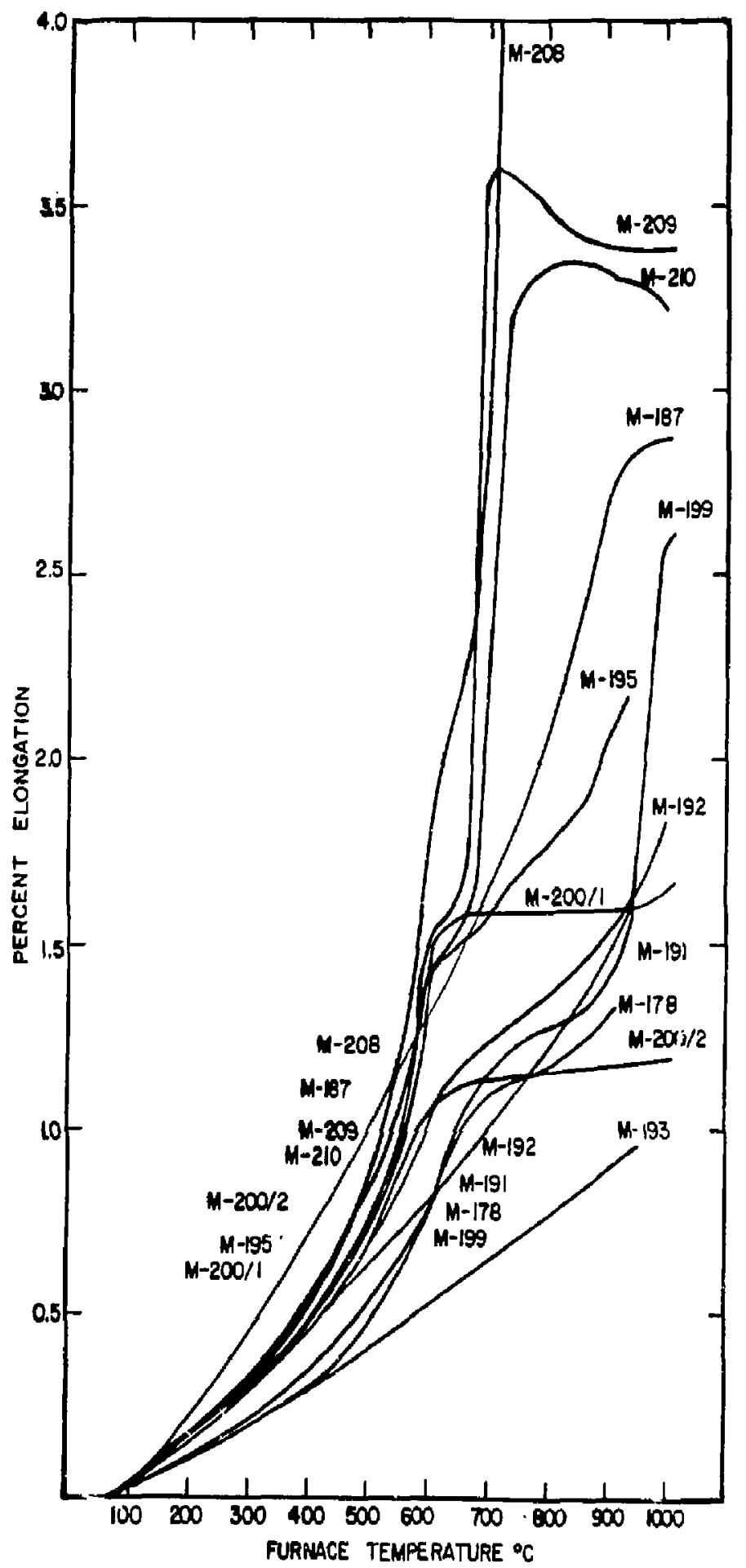

PIGURE 1. 29 Avirage linear expansion of rocks af good and falr plerceabllity

Source: Clark et 1,1969 ard Geller et al, 1962. 
was tested at $240^{\circ} \mathrm{C}$ in a dry nitrogen atmosphere, the compressive strength was about 20,000 psi. If the atmosphere is now changed to a saturated water vapor and the tests redone, the strength drops to about 6,000 psi. Unfortunately, at present there is relatively little test data available on the effect of environmcital conditions on the strength of various rocks. This, however, can be an extremely important consideration in evaluating the long-term competence of a repository. 
TABLE i-18. Compression tests on granite.

(Machine loading rate $-5 \mathrm{mils} / \mathrm{min}$ )

$\begin{array}{lclc}\begin{array}{l}\text { Prior } \\ \text { Treatment }\end{array} & \begin{array}{l}\text { Test } \\ \text { Temperarure }\end{array} & \begin{array}{l}\text { Test } \\ \text { Atmosphere }\end{array} & \begin{array}{l}\text { Average } \\ \text { Failure } \\ \text { Stress, MPa }\end{array} \\ \begin{array}{l}\text { 60 hours in } \\ \text { saturated steam } \\ \left(240^{\circ} \mathrm{C}, 345 \mathrm{MPa}\right)\end{array} & 25^{\circ} \mathrm{C} & \begin{array}{l}\text { saturated } \\ \text { water vapor }\end{array} & 151.7 \\ \text { None } & 240^{\circ} \mathrm{C} & \text { dry nitrogen } & 135.9 \\ \text { None } & 240^{\circ} \mathrm{C} & \begin{array}{l}\text { saturated } \\ \text { water vapor }\end{array} & 41.4 \\ \text { None } & 25^{\circ} \mathrm{C} & \begin{array}{l}\text { saturated } \\ \text { water vapor }\end{array} & 162.1 \\ \text { None } & -i 95^{\circ} \mathrm{C} & \begin{array}{l}\text { liquic } \\ \text { nitrogen }\end{array} & 257.9\end{array}$

SOURCE: Charles, 1959. 


\subsection{OTHER CONSIDERATIONS}

To date, most of the studies have been performed using rock types which are considered to be "homogeneous and isotropic." The assumption is made that average properties do not vary markedly from point-to-point within the rock mass, and that they do not vary substantially with respect to orientation. This is borne out by a number of experimental investigations carried out in the laboratory. Table $1 \mathrm{~m}$ I9 shows the results of tests mace on a number of samples taken at various orientations from a block of stripa granite., It is noted that Young's modulus, wave velocity, compressive strength, and density are relatively insensitive to orientation. Table 1-20, however, presents the results of another set 0 E experiments that were done on a gneissose granite. Therefore, there are sore rock masses for which directional properties must be consideres.

Decause of the very long time frame that one mint be concerned about ropository behavior, it is important to consider the effect of creep on rock strength and rook behavior. Although there has been a considerable amount of information collected on the sehavior of salt and salt-like materials, relatively little work has been done on the areep relationship 
TABLE 1-29. Small-scale anisotropy test results.

\begin{tabular}{|c|c|c|c|c|c|c|}
\hline \multirow[t]{2}{*}{$\begin{array}{l}\text { Specinen } \\
\text { number }\end{array}$} & Density & \multicolumn{2}{|c|}{$c_{1}$ Have velocity } & \multicolumn{2}{|c|}{$\begin{array}{l}\text { Y Youngs } \\
\text { modulus }\end{array}$} & $r_{c}$ \\
\hline & $\left(\mathrm{kg} / \mathrm{m}^{3}\right)$ & $(\mathrm{m} / \mathrm{s})$ & $\begin{array}{l}\text { mean } \\
\text { s.d. }\end{array}$ & $(G \mathrm{~Pa})$ & $\begin{array}{l}\text { mean } \\
s, d \text {. }\end{array}$ & (YPa) \\
\hline $\begin{array}{l}\text { B1.1 } \\
\text { B1.? }\end{array}$ & $\begin{array}{l}2616.9 \\
2616.9\end{array}$ & $\begin{array}{l}5164.2 \\
5196.3\end{array}$ & $\begin{array}{r}5180.3 \\
\pm 16.1\end{array}$ & $\begin{array}{l}66.8 \\
63.0\end{array}$ & $\begin{array}{l}64.9 \\
\pm 2.0\end{array}$ & $\begin{array}{r}227.4 \\
81.2\end{array}$ \\
\hline $\begin{array}{l}\text { B2.1 } \\
\text { B2.2 }\end{array}$ & $\begin{array}{l}2614.4 \\
2609.8\end{array}$ & $\begin{array}{l}5268.8 \\
5213.0\end{array}$ & $\begin{array}{r}5240.9 \\
\pm 27.9\end{array}$ & $\begin{array}{l}65.8 \\
64.6\end{array}$ & $\begin{array}{l}65.8 \\
\pm 0.6\end{array}$ & $\begin{array}{l}237.2 \\
227.4\end{array}$ \\
\hline $\begin{array}{l}\text { B3.1 } \\
\text { B3. } 2\end{array}$ & $\begin{array}{l}2613.8 \\
2616.3\end{array}$ & $\begin{array}{l}5310.1 \\
5312.1\end{array}$ & $\begin{array}{r}5311.1 \\
\pm 1.0\end{array}$ & $\begin{array}{l}64.4 \\
66.6\end{array}$ & $\begin{array}{l}65.5 \\
\pm 1.2\end{array}$ & $\begin{array}{l}207.6 \\
233.9\end{array}$ \\
\hline $\begin{array}{l}\text { B4.1 } \\
34.2\end{array}$ & $\begin{array}{l}2617.8 \\
2619.7\end{array}$ & $\begin{array}{l}5353.5 \\
5409.7\end{array}$ & $\begin{array}{r}5831.6 \\
\pm 28.1\end{array}$ & $\begin{array}{l}64.4 \\
67.0\end{array}$ & $\begin{array}{l}65.7 \\
\pm 1.4\end{array}$ & \\
\hline
\end{tabular}

SOLRCE: Swan, 1978 
Table 1-20 Summary of Anistropic Properties of Granite

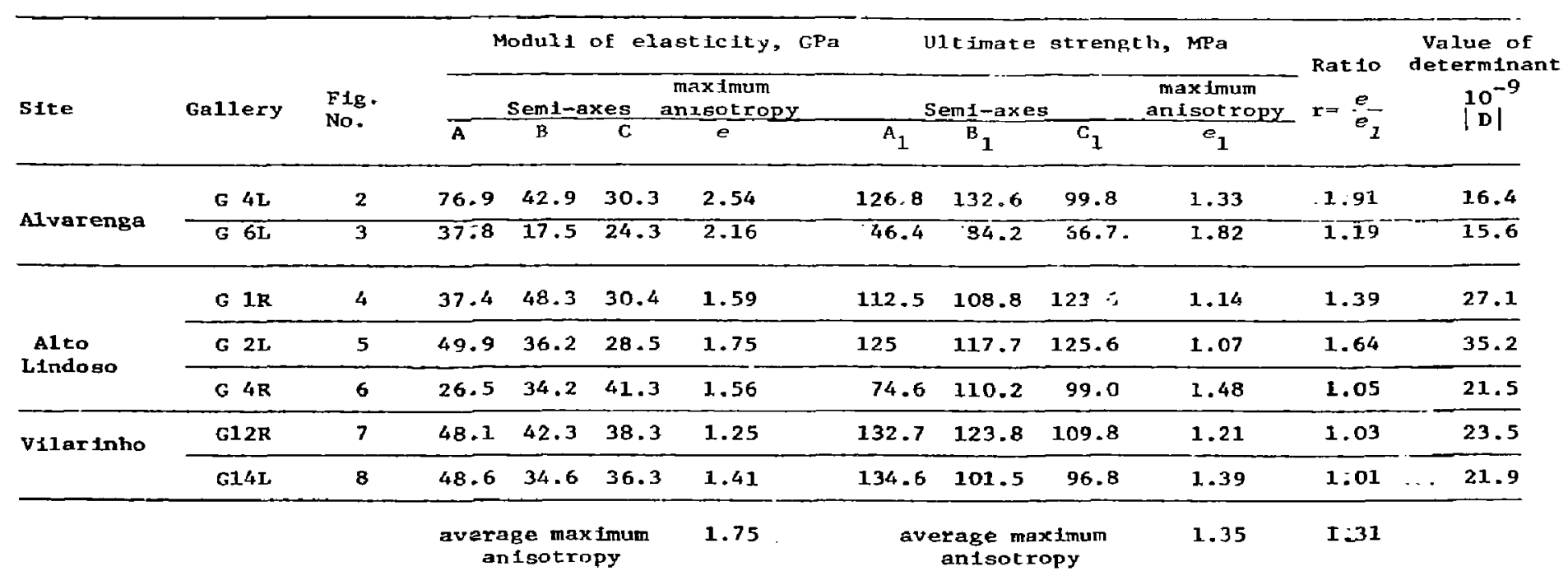

Source: Rodrigues (1970) 
for hard rocks, such as granite, stress-time and strain-time relationships for westerly granite are presented in Figures 1-30 and 1-31. In Figure 1-30, it is observed that over a period of from 25 to 250 hours the strength of westerly granite decreased from about 31,000 psi to 27,000 psi. From the data, it is not clear whether the strength will continue to decrease, or if it will reach sore plateau. This is extremely important when evaluating long-term behavior. For westerly granite samples under a constant load of 26,630 psi, (figure 1-31) the strain increased rather rapidly, then increased at a constant rate which changed into tertiary creep, and the sample finally failed. Table 1-21 is a summary of creep data collected at room temperature for two granites and one granite iorite. Note that the strain is related to the stress $y$ aised to an exponent varying between 1 and 1.3. Although important, the collection of good creep data is extremely difficult, due to the very long time frames involved and the sophistication of equipment necessary to provide the control of loading. Present data are insufficient to incorporate creep into predictive models for hard rock repositories.

There are some other factors which should be considered in evaluating geomechanical aspects of repositories in granite. One factor is the behavior of rock under cyclic loading conditions. The rock mass itself will undergo a heating and 


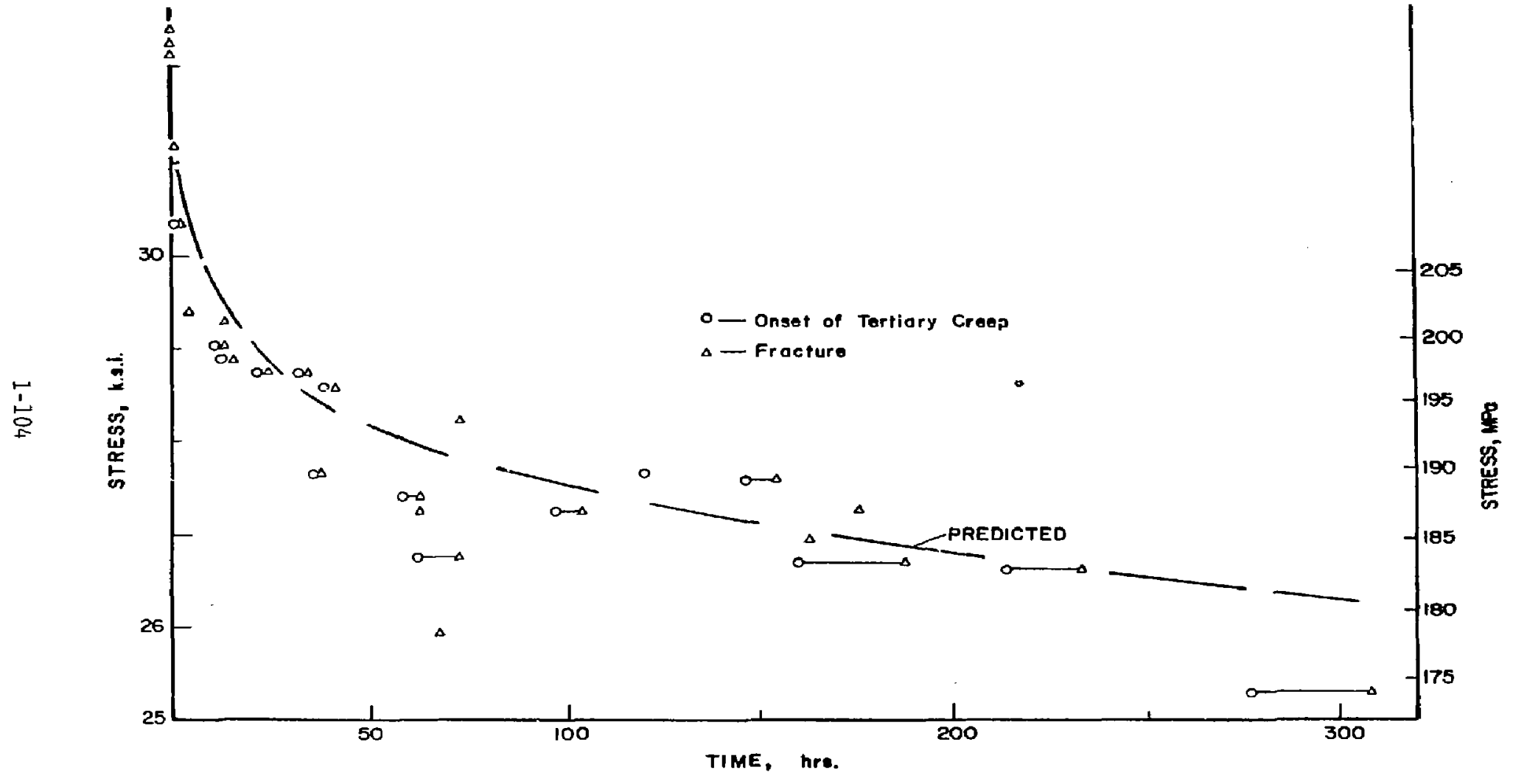

FIGURE 1-30 Strength-time relationshlp for Westerly granite Source: Wawergik, 1974. 


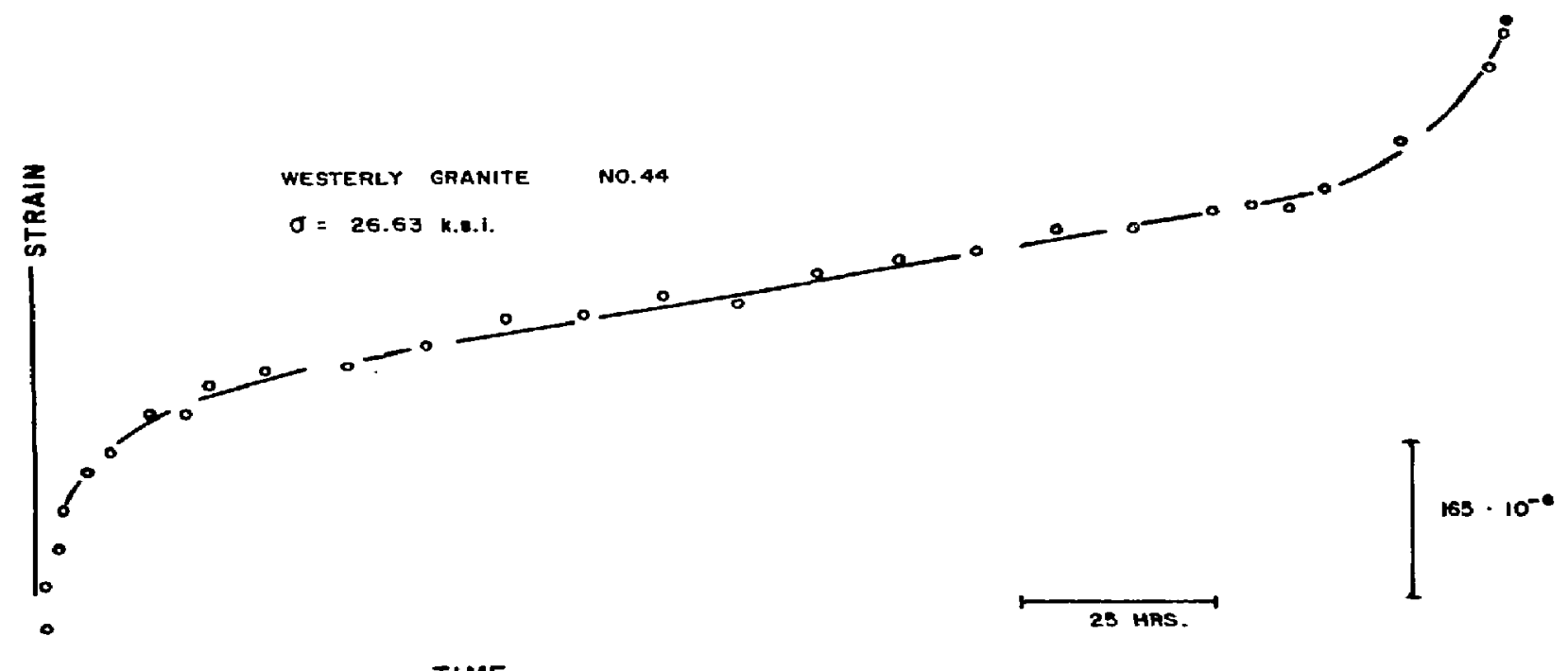

FIGURE 1-31 Typfal creep curve of water-saturated Westerly grante Source: Wawerstk, 1974. 
TABLE 1-21. Values of the exponent $n$ In the equation $E=$ Aon 1 in the creep of grantites and a granodiortie at room temperature (Robertson, 1964)

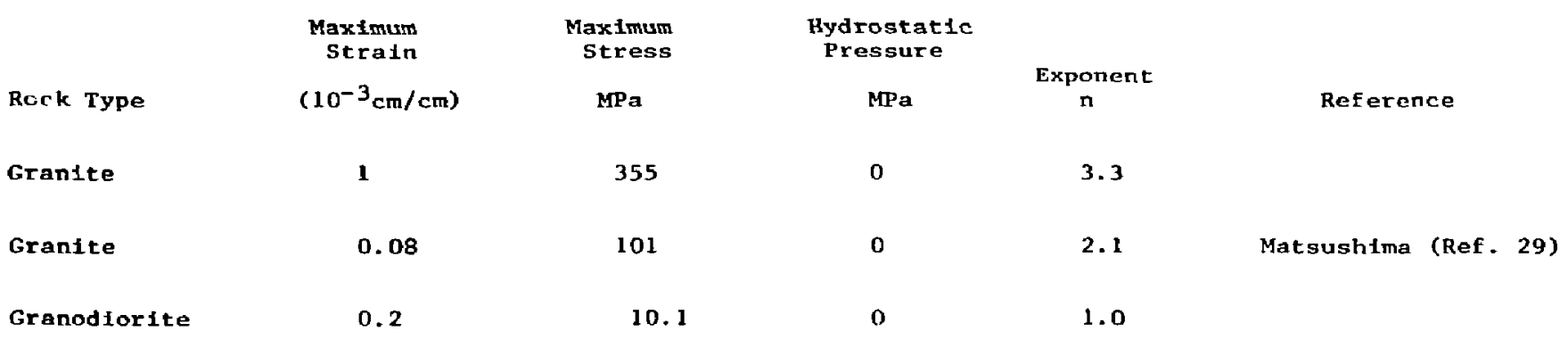

SOURCE: Offlce of Waste Isalation, I978 
then a cooling phenomenon and the effects of this cycling are not necessarily reversible. Very little information exists at present regarding this pheromenon. Rock materials may also weaken due to radiological or chemical effects. 


\subsection{SCALING OF LABORATORY RESULTS}

The discussion to this point has focused primarily on intact rock samples. It is well known, however, that in underground excavations it is not the intact rock that causes problems, but rather the discontinuities, such as jointing, faulting, dikes, etc. There are many ways of trying to incorporate such discontinuities into a design. One method is to model individual features and to describe them in terms of joint stiffnesses, both normal and shear. Another approach is to treat the entire rock mass as a continum, but to reduce the modulus, strength and other properties obtained in the laboratory for intact rock. The most comflon approach is to zake laboratory properties and apply some sort of scale factor to them to obtain a first estimate of the field properties.

Table 1-22 (ONWT, 1978) is a comparison of rock properties for generic granite. One column is for intact rock, and the adjacent one is for the rock mass. In comparing these two columns, one will notice differerces between the intact rock and the rock mass in only three properties. They are the Young's modulus, uniaxial compressive strength, and tensile strength. All the other values are assumed to be the same between the intact rock and the rock mass, Note that Young's modulus has been reduced by a factor of 3 , the 
TABLE 1-22 Rock propertles for a generle granite

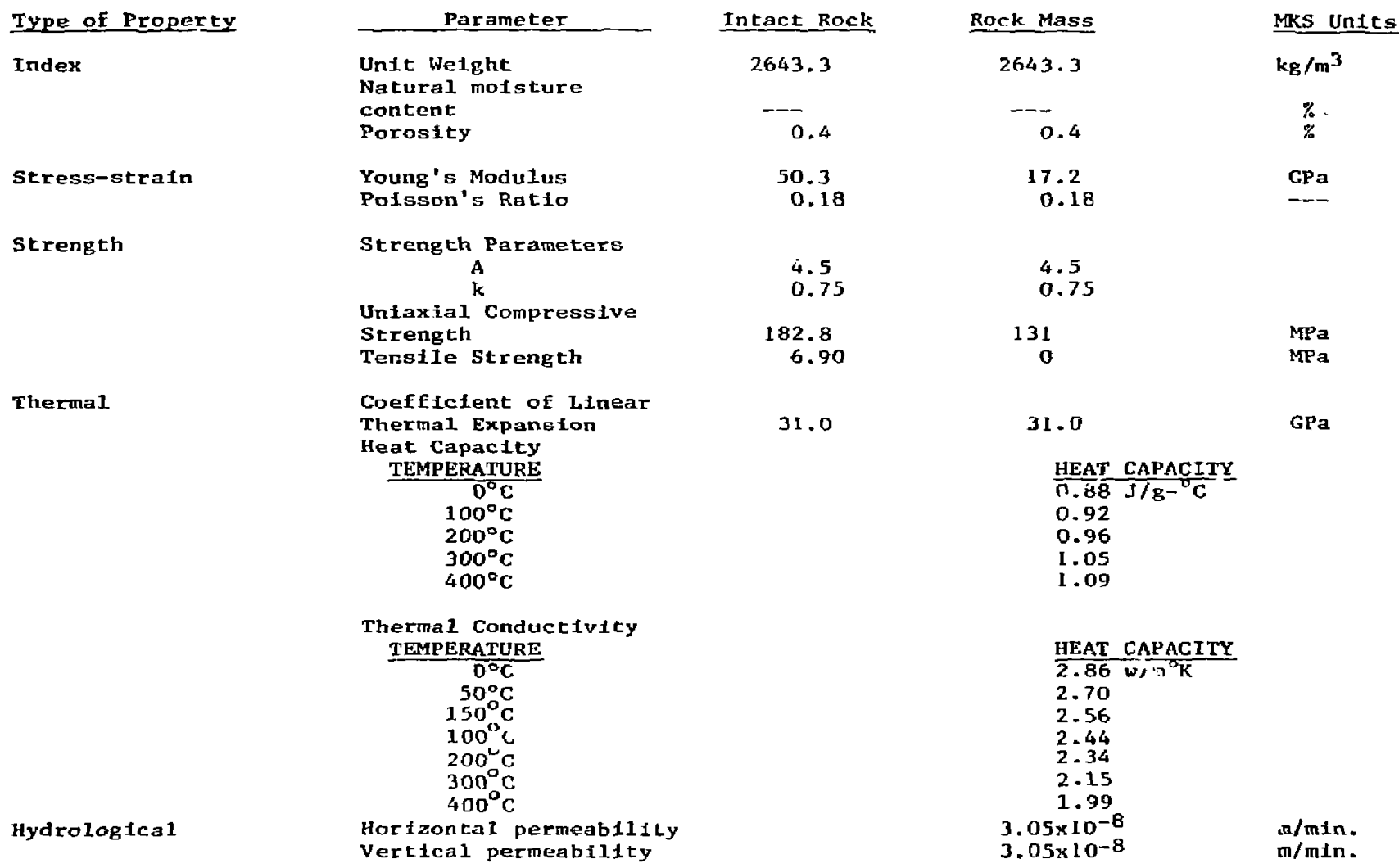

SouRCE: Office of Waste Isolation, 1978 
compressive strength by about 30\%, and the tensile strength reduced from $6.9 \mathrm{MPa}$ to 0 . These figures are considered to be extremely misleading and should not be used for modeling purposes.

The apparent modulus of a rock mass can be very low under small loads since it is determined primarily by the closing of joints, etc. (Very large deformations are possible under rather low stresses, With internal boundaries, discontinuities tend to absorb the displacement, and Poisson's ratio may actually be close to 0 . The uniaxial compressive strength of cubes, for example, for some materials has been shown to vary as the inverse of the square root of the length of the side. For samples of other shapes, the strength is dependent upon the width-heighth ratio. Assuming that the values for intact rock given in the table are for samples of the order of $5 \mathrm{~cm}$ in diameter and $10 \mathrm{~cm}$ long, on this basis, the rock mass values correspond to relatively small sample sizes. The tensile strength of intact rock, as has been noted earlier, varies from 0 to scme fraction, generally $1 / 10$ to $1 / 20$ of the compressive strength of the rock. If the tensile strength of the rock mass were really 0 , it would be extremely difficult to support openings such as are created underground every day in granitic rocks. 
An example of variation in strength with size has been provided by (Pratt et al, 1979), as shown in Figure 1-32. Note that it would appear that there is a characteristic length of $1 / 2$ to 1 meter, at which strength becomes relatively constant, The variation in strength with sample size, as shown in the figure, suggests that for large samples the strength would be,perhaps, an order of magnitude lower than for smaller samples. The 0.5 meter characteristic length may not be at all appropriate, when large openings are considereo, since some other characteristic discontinuity would then be the determining factor for rock mass strength.

The modulus would be expected to follow a similar trend, as it is closely related to compressive strength. Figure $1-33$ shows the relationship between the insitu modulus and the number of fractures which were observed in the core. As can be seen, there is a rather strong correlation between the number of fractures and the modulus, with the moduilus decreasing as the fracture number increases. Figure 1-34 shows insitu modulus results for stripa. These tests were conducted in $3.8 \mathrm{~cm}$ diameter holes drilled into the rock mass. The volume of rock influenced by the rest was relatively small, although much greater than what would be experienced in testing the core taken from the same hole. Note that the average insitu modul us for the relatively small volume was on the order of $1 / 2$ of the laboratery value. 


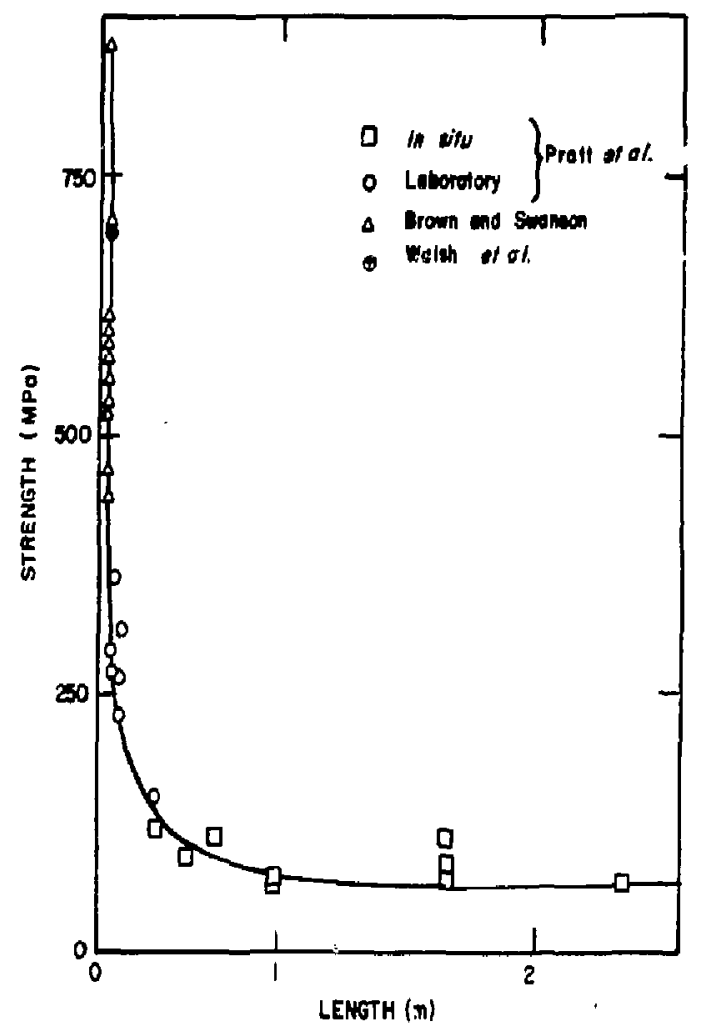

FIGURE 1-32 A diagram illustrating the effect of size on the uniaxial compressive strength of quartz diorite Source: Pratt et al, 1972. 


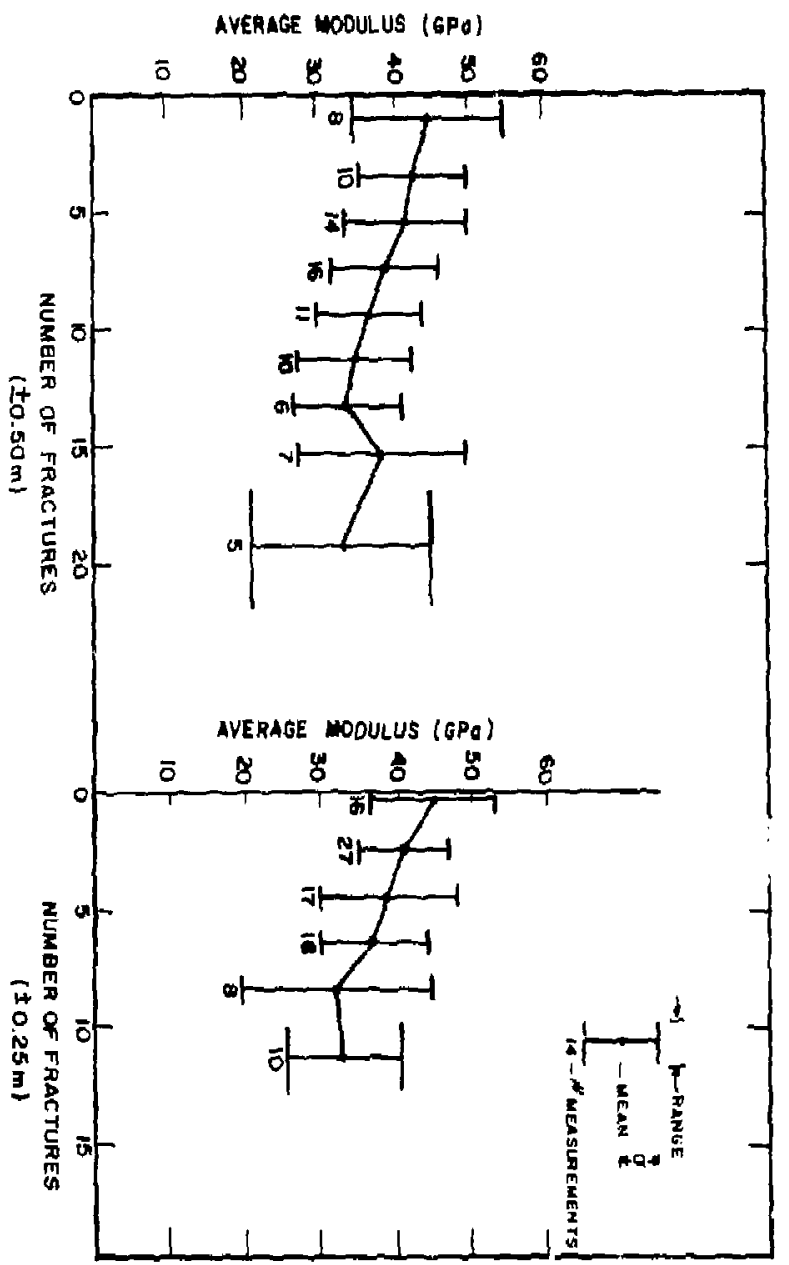

FIRURE 1-33 Insitu Young 's modulus determinations versus fracture density from visual inspection of core Source: Nelson et 1, 1979. 


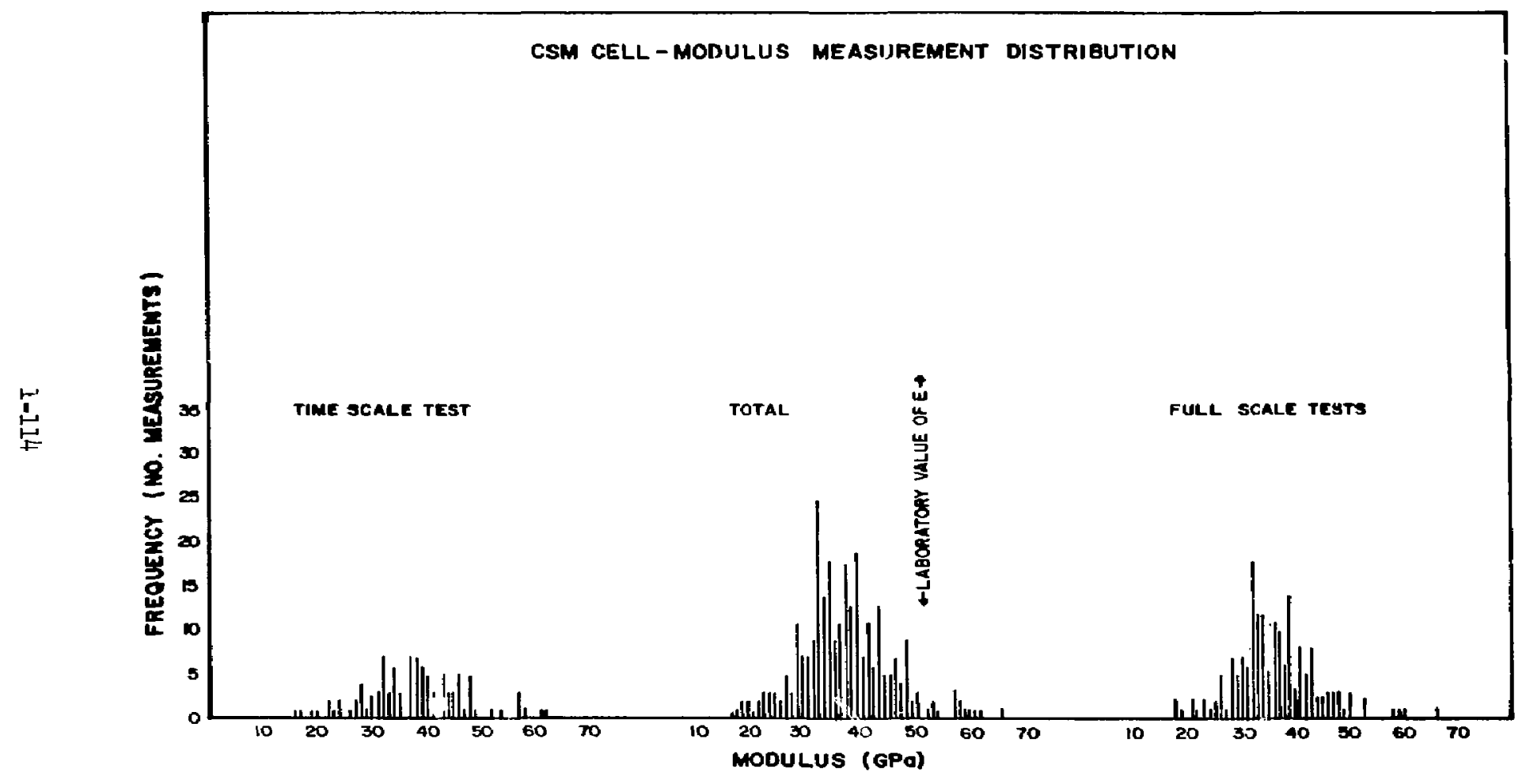

FigurE 1-3.4 Histograms of CSM-cell determinations of Young's morulus Source: Nelson et al, 1979 . 
Due to this problen of not being able, at the present time, to assess insitu properties from tests performed on small samples o:: rock, a number of insitu test experiments are either underway or planned at stripa. The purpose of such experiments is to gather thermal and mechanical data appropriate for loading conditions similar to those which would be expected in an actual repository. Models are being prepared for predicting the field behavior. of crucial importance is how well the input parameters des'ribe the actual field situation.

The initial predictions will be made using laboratory values for thermal conductivities, specific heat, density, thermal diffusivity, coefficient of linear expansion, Poisson's ratio, and Young's modulus such as those given in table 1-23. which were applied at stripa, or some modified scaled laboratory values might be appropriate. The problem in the latter case is justifying the scaling values which are used for the initial approximation. The procedure is to compare predicted values with those actually measured and then to (a) revise the estimate of the input parameters so that agreement is reached between predicted and experimental and/or (b) reevaluate the form of the model which is used. If the initially predicted and actual field results do not agree, the input parameters are then scaled to those reguired to achieve agreement. Model verification and validation can ther only be evaluated by 
TABLE 1- 23 Laboratory values for stripa granite used to the simulations

Themal conductivity Specific heal

Density

Thermal diffustvity

Coefficient of inear

themal expansion

Poisson's ratio

Youngs modulus
- $\quad 3.2\left(\mathrm{~W} / \mathrm{m}^{\circ} \mathrm{C}\right) ;$

- $\quad 837\left(\mathrm{~J} / \mathrm{kg}^{\circ} \mathrm{C}\right)$;

- $2600 \mathrm{~kg} / \mathrm{m}^{3}$;

- $\quad 1.47 \times 10^{-6}\left(\mathrm{~m}^{2} / \mathrm{s}\right)$;

$=\quad 11,1 \times 10^{-6}\left(/^{\circ} \mathrm{C}\right)$

$=0,23$;

- $\quad 51,3(\mathrm{GPa})$

L

I.

1

1

L

1

L

I.

1 
applying the revised model "input data" tu a new loading situation. A comparison of the theoretical predictions made using properties collected from small intact samples and the actual field measurements from preliminary measurements of the Stripa Mine are shown in Figures 1-35 through 1-41. It is observed that predicted temperatures and actual temperatures based upon laboratory values for thermal conductivity, density, diffusivity, and specific heat are very good, suggesting that size effects on such thermal parameters may be relatively small. As seen in Figures 1-39, 1-40 and 1-41, however, the predicted and actual displacements are quite different, with the actual values being considerablv less than those projected.

These predictions are based upon single "average" laboratory values for Young's modulus and the linear thermal expansion coefficient. The initial portions of the displacement curves differ the most with the actual curves showing essentially no displacement for a considerable period of time. Eventually, they follow a slope, not too unlike that predicted from theory. This can be easily explained by the presence of joints or other discontinuities between the measurement points which absorb internally any displacement. They could also be explained by non-linear Modulus-temperature and/or expansion coefficient-temperature curves. There could, of course, be a number of other reasons for this disparity. 

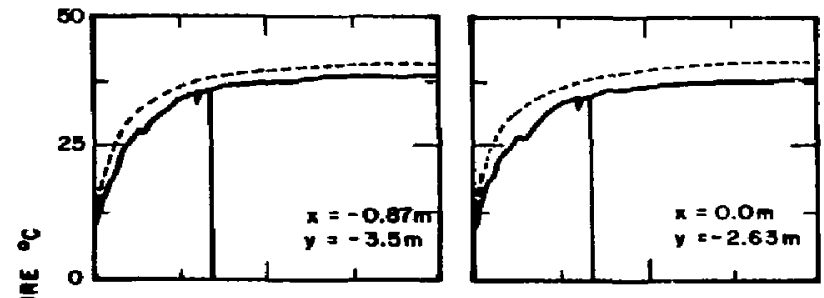

总

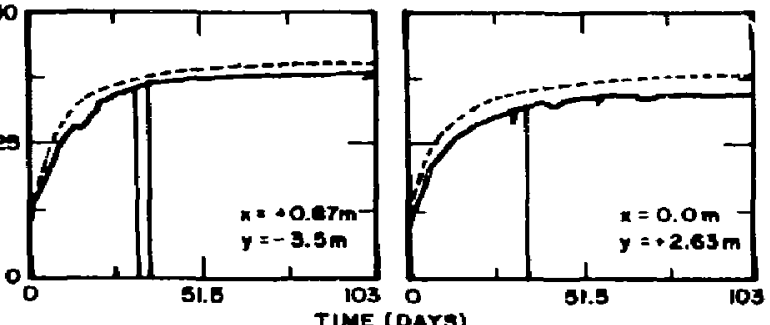

FIGURE 1-35 Curves showing the predicted and measured temperatures as a function of time at a radius of $0.87 \mathrm{~m}$ from the mid-points of the two innermost heaters on the $y$-axis Source: Cook and Hood, 1978.

Note: The neur vertical excursions of the measured values reflect malfunctions in the data collection system.

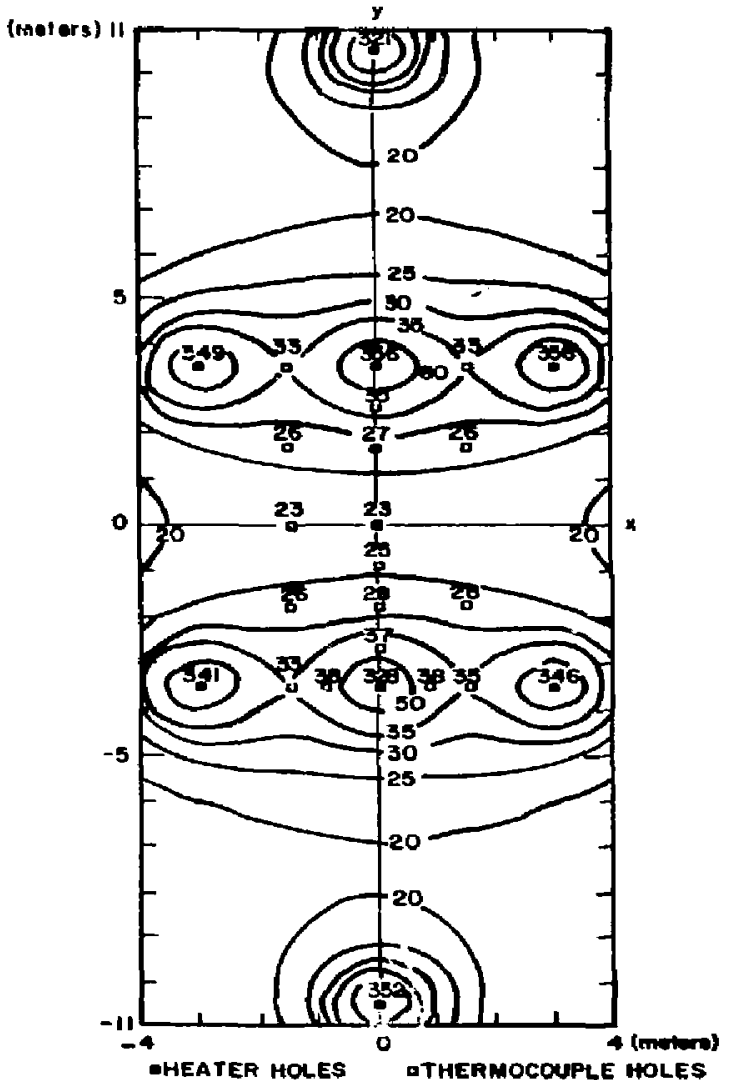

FIGURE 1-36 Predicted 1sotherms and measured temperatures In a horizontal plane through the middle of the time-scale expertiment 90 days after heat ing had started Source: cook and Hood, 1978 . 


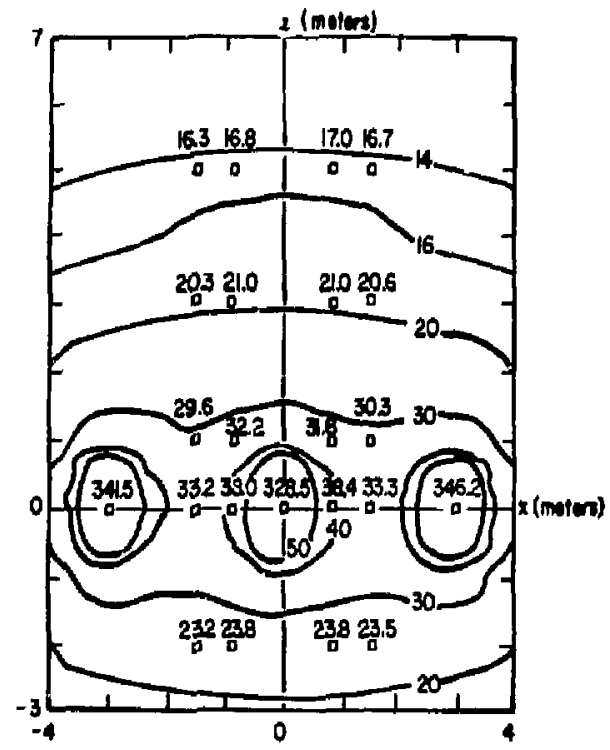

FICURE 1-37 Predicted 1sotherms and neasured temperatures in a vertical plane $(y=-3,5 x)$ contalning three of the time-gcale heaters, 90 days af ter heating had started

Source: Cook and tood, 1978.

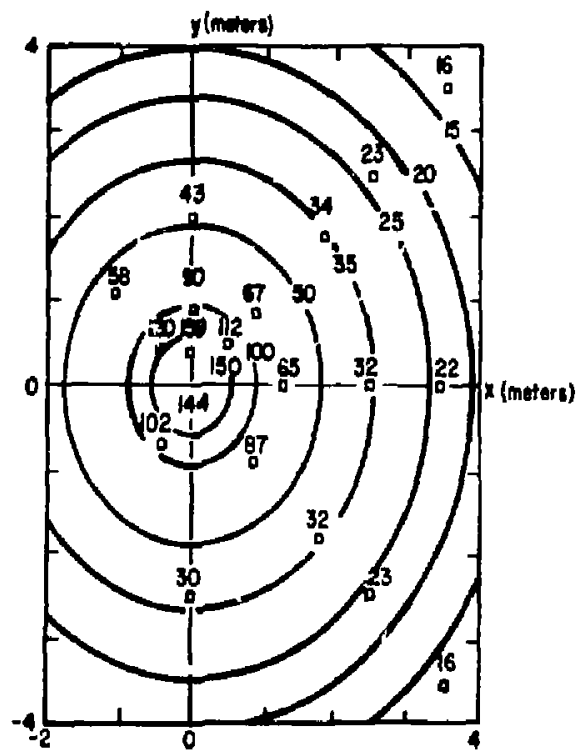

FIGURE 1-38 Predicted fsotherns and weasured temperatures in a horizontal plane through the aiddle of the $5 \mathrm{kw}$ fullBcale heater, 65 days ofter heating had started

Source: Cook and Hook, 1978. 


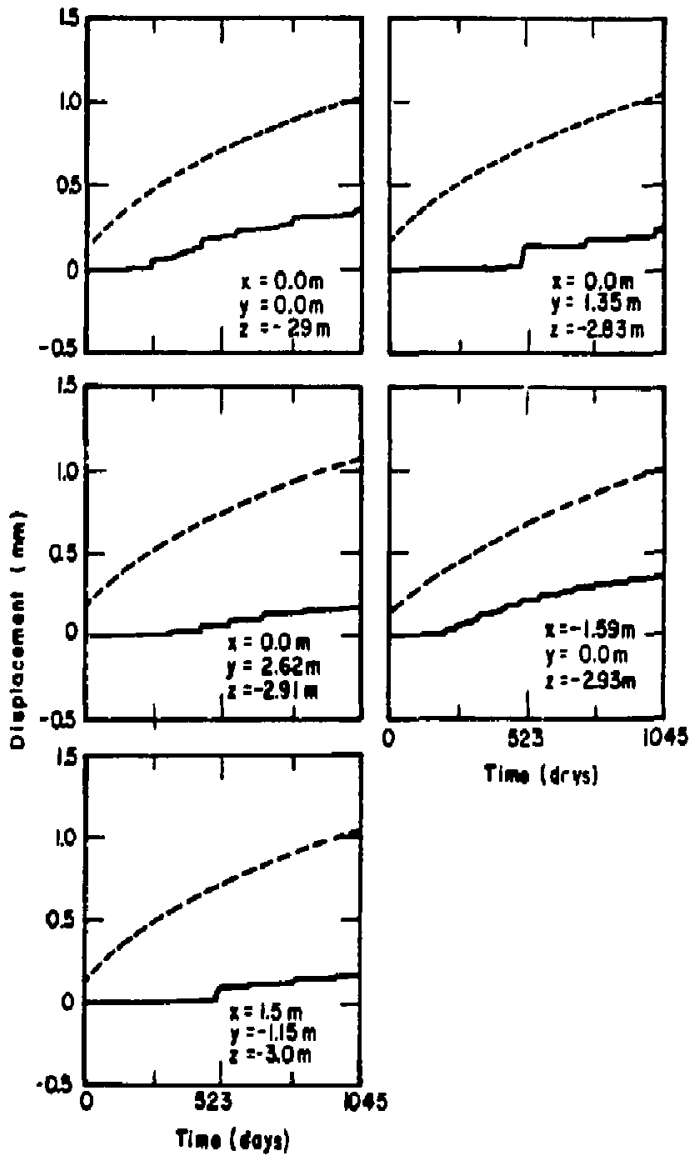

FIGURE 1-39 Predicted (dashed) and measured (solid) relative displacements between anchor points 3 m below the heater mid-plane and the hole collars in the floor of the time-scale drift, plotted as a function of time So'srce: Cook and Hood, 1978. 


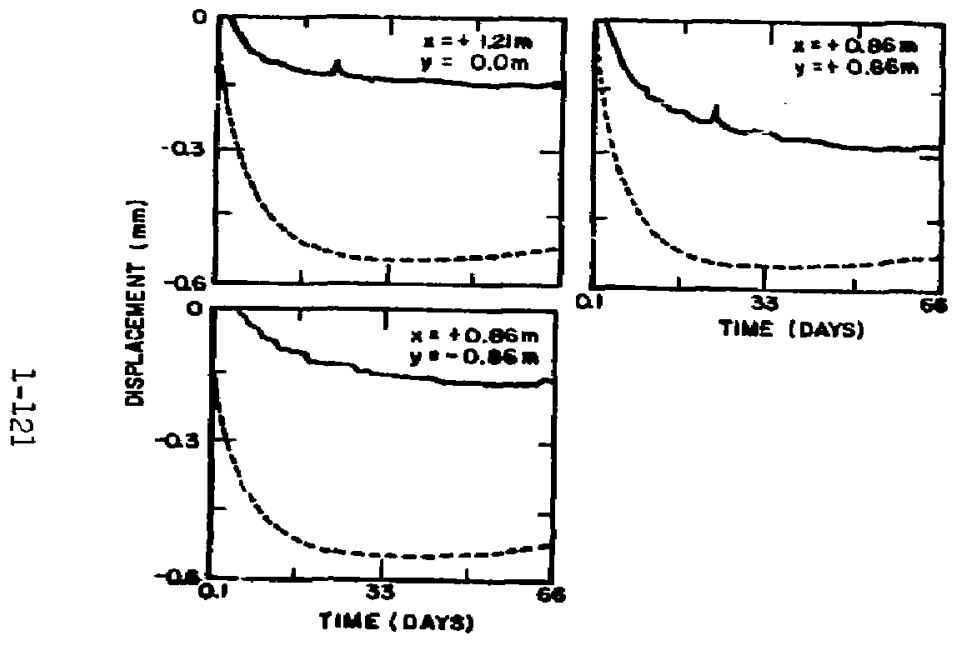

IGURE 1-40 Predicted and meapured horizontal diaplacemente of the rock in the mid-plane of the $5 \mathrm{~kW}$ full-eedie heiter taken along different directions.

Source: Cook and Hood. 1978.

Note: These curves show relative d.eplacenent between anchor points at adial diatence of $1.2 \mathrm{~m}$ from the heater and the collar of the hole on the wall of the extengometer drift.

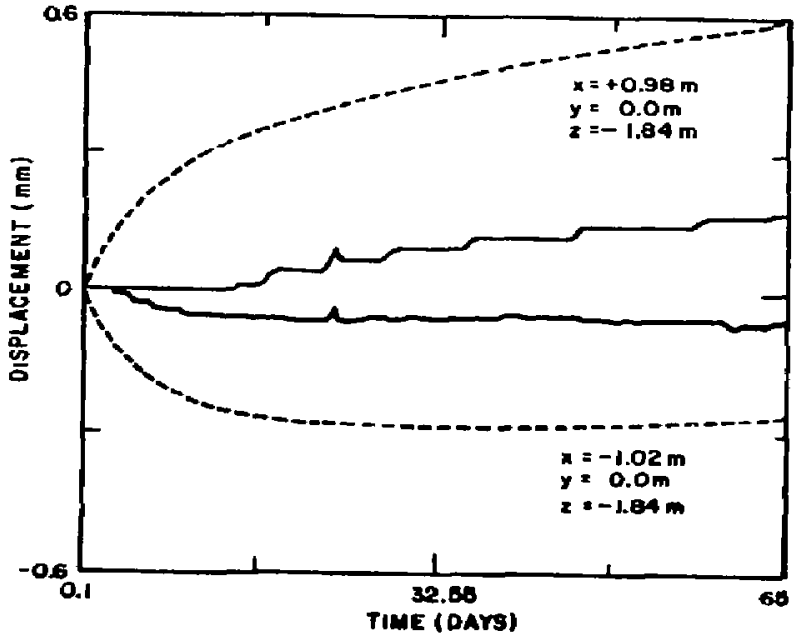

FIGURE 1-41 Predicted and mensured hortzontel displacements below the $5 \mathrm{~kW}$ full-gcale heater at anchor pointa symetrically positioned on each alde of the heater. Source: Cook and Hood, 1978 .

Note: Both of thege diaplacements are mensured relative tot he collar of the hole on the wall of the extensometer drift. 
The important point is that this should not be concluded as a failure of the theory to adequately predict the results. It is, rather, the inability of researchers to insert into models the appropriate rock mass parameters, whether they be mechanical paranters such as strength, density, etc.; thermal parameters, or thermoelastic parameters.

The major emphasis in the near future will be on the gathering and evaluating insitu rock mass characteristics which can be used in presently-existing models for adequately defining and explaining full-scale experiments and projected repository behavior. 


\subsection{REFERENCES}

Abou-Sayed, A.S., and E.E. Brechtel, "Experimental Investigation of the Effects of Size on the Uniaxial Compressive Strength of Cedar City Quartz Diorite", I7th U.S. Symposium on Rock Mechanics, 1976.

Advani, S.H., and K.Y. Lee, "Thermo-Mechanical Failure Criteria for Rock Media", 20th Syt.posiun on Rcck Mechanics, Austin, Texas 1979.

Anderson, B., and P.A. Halen, "Mining Mathods Used in the Underground Tunnels and Test Rooms at Stripa", LBL 7081, August, 1978.

Apps, J.A., Cook, N.G.W., and I.A. Witherspoon, "An Appraisal of Underground Radioactive Waste Disposal in Argillaceous and Crystalline Rocks: Some Geochemical, Geomechanical, and Hydrogeological Questions", LBL 7047, June, 1978.

Balmer, G.G., "Physical Properties of Some Typical Foundation Rocks", U.S. Bureau of Reclamation, Concrete Laboratory Report Sp-39, August 13, 1953.

Barbish, A.B., and G.H.F. Gardner, "The Effect of Heat on Some Mechanical Properties of Igneous Rocks," Journa; of Society of Petroleum Engineers, December, 1969.

Barton, N., "The Shear Strength of Rock and Rock Joints", IJRM, Sept., 1976.

Bauer, S.J., and B. Johnson, "Effects of Slow Uniforw Heating on the Physical Properties of the Westerly and Charcoal Granites" 20th Symposium on Rock Mechanics, Austin, Texas, 1979, Pp. 7-18.

Bieniawski, Z.T., and W. L. Van Heerden, "The Significance of Insitu Tests on Large Rcck Specimens", IJRM, April, 1975.

Birch, F., Compressibility: Elastic Constants, p. 98, in Handbook of Physical Constants, S. Clark, ed., Geological Society of American Mem. 97, 1966, 587 p.

Brace, W.F., Walsh, J.B., and Frangos, W.T., Permeability of Granite Under High Pressure. Jour. Jeophy. Res. 7322251968.

Byerlee, J.D., "Static and Kinetic Friction of Granite at High Normal Stress", IJRM, Nov. 1970 (international Joumal of Rock Mechanics \& Mining Sciences).

Carlsson, H., "Stress "feasurements in the Stripa Granite", LBL :078, August, 1978.

Chappell, B.A., "Component Characteristics of Jointed Rock Masses", IJRM, April, 1975. 
Charles, R.J., "The Strength of Silicate Glasṣes and Some Crystalline Oxides", Conf. on Eracture, Swampscott, Mass., April, 1959.

Charlwood, R.G., and P.F. Gnirk, "Conceptual Design Studies for a High Level Waste Repository in Igneous Rock", Storage in Excavated Rock Caverns (Proceedings of Rock Store 77), Stockholn, Sweeden, 1977, Vol. 3.

Clark, G.B., et al, "Rock Properties Related to Rapid Excavation", Final Report To Office of High Speed Ground Transportation (Contract 3-0143), March, 1969.

Cook, N.G.H., "An Appraisal of Hard Rock For Potential Underground Repositories of Radioactive Wastes", LBL Report 7004, Dctober, 1977.

Cook, N.G.W. and P.A. Witherspoon, "Mechanical and Thermal Design Considerations For Radioactive Waste Repositories in Hard Rock", LBL 7073, October, 1978.

Cooper, H.W., and Simmons, Gene, The Effect of Cracks on the Thermal Expansion of Rocks. Earth and Planetary Science Letters $36404,1977$.

Deere, D.U., and Miller, R.P., "Engineering Classification and Index Properties for Intact Rock", Air Force Weapons Lab Tech. Report, AFWL-TR-65-116, Dec. 1966.

Freeman, D. C., Sawdye, J.A., and F.A. Mumpton, "Mechanism of Thermal Spalling in Rocks", 1lth Symposium on Rock Mechanics; Quarterly CSM, V58, N4, Oct. 1963.

Friedman, M. and b. Johnson, "Thermal Cracks in Unconfined Sioux Quartzite", 19th Symposium on Rock Mechanics, Lake Tahoe, Nevada, 1978.

Friedman, M., Handin, J., Higgs, N.G., and J.R. Lant2, "Strength and Ductility of Four Dry Igneous Rocks at Low Pressures and Temperatures to Partial Melting", 20th Symposium on Rock Mechanics, Austin, Texas, 1979.

Geller, L.B., et al, "Jet Piercing Research Project", Dept. of Mines \& Mineral Survey, Mines Branch, IR 62-27, 1962.

Goetze, C., "High Temperature Rheology of Westerly Granite", J. of Geophysical Research, Vol. 76, 1971.

Goldsmith, W., Sackman, J.L., and C. Ewert, "Static and Dynamic Fracture Strength of Barre Granite", IJRM, Nov. 1976. 
Griggs, D.T., Turper, F.J. and H. C. Heard, "Deformation of Rocks at $500^{\circ}$ to $800^{\circ} \mathrm{C}$ ", Rock Deformation, Griggs and Handin, GSA Memoir 79, 1360.

Handin, John, Strength and Ductility in Handbook of Physical Constants, S. Ciark ed. Geol. Soc. America Mer, 97, 1966, 587 p.

Hanley, E.J., Dewitt, D.P., and R.F. Roy, "The Thermal Diffusivity of Eight Well-Characterized Rocks for the Temperature Range 300-1000 ${ }^{\prime \prime}$, Engineering Geology, 12, 1978, pp. 31-47.

Hasan, S.E., "Thermophysical Properites of Rocks", 19th U.S. Rock Mechanics Symposium, 1978.

Herget, G., Pahl, A., and 0liver, P., "Ground Stresses below 3000 feet", Proc. 9th Can Rock Mechanics Symp., Kingston, Ontario, 1975, pp. 281-307.

Herget, G., and K. Unrug, "Insitu Rock Strength From Triaxial Testing", IJRM, Nov. 1976.

Hoek, E., and E.T. Brown, Underground Excavation Engineering, The Institution of Mining and Metallurgy, London, In Press.

Jamison, D.B., and N.G.W. Cosk, "An Analysis of Measured Values for the State of Stress in the Earth's Crust", LBL 707I, Aug. 1978.

Johnson, B., Gangi, A.F., and J. Handin, "Themal Cracking of Rock Subjected to Slow, Uniform Temperature Changes", 19th Syuposium on Rock Mechanics, Lake Tahoe, Nev. 1978.

Lee, C.F., "Design of Hydraulic Tunnels in Rock For Generating Stations", Ontario Hydro (Geotechnical Engineering Dept.), Feb. 1978.

Lehnhoff, T.F., and J.D. Scheller, "The Influence of Temperature Dependent Properties on Thermal Rock Fragmentation", IJRM, 1975.

Lindner, E.N., and J.A. Halpern, "Insitu Stress: An Analysis", 18th U.S. Symposium on Rock Mechanics, 1977.

Iindroth, D.P., and W.G. Krawza, "Heat Content and Specific Heat of Six Rock Types at Temperature to $1000^{\circ} \mathrm{C}^{\prime \prime}$, USBM RI7503, 1971.

Iundborg, N. "The Strength - Size Relation of Granite", IJRM, Ju1y, 1967.

Mahtab, M.A., Ratigan, J.L., D.R. McCreath, "Stability of Radioactive Waste Repository in the Canadian Shield", 18th U.S. Symposium on Rock Mechanics, 1977. 
Mirkovich, V.V., "Experimental Study Relating Thermal Conductivity to Thermal Piercing of Rocks", IJRM, May, 1968.

Nelson, P., et al, "Preliminary Report on Geophysical and Mechanical Borehols Measurements at Stripa", LBL 8280, May 1979.

Office of Nuclear Waste Isolation (ONWI), "Technical Support for GRIS: Radicactive Waste Isulatio: in Geologic Formations Volume 5, Baseline Rork Properties, Granite, Y/OWI/TM-36/5, April, 1978.

Parson, Brinckarhoff, Quade and Douglas, Inc., "Thermal Guidelines for a Repository in Bedrock", Y/OWI/SUB-76/16504, Sept. 1976.

Perami, R., "The Formation of Microcracks in Rocks as a Result of Temperature Variations-(In French)", Proceedings Int. Symp. on Rock Fracture Nancy, Franc2, 1971.

Pratt, H.R., et a1, "Elastic and Transport Properties of an Insitu Jointed Granite", IJRM Jan, 1977.

Pratt, H.R., et al, "The Iifect of Specimen Size on the Mechanical Properties of Unjointed Diorite", IJRM, July, 1972.

Pratt, H.R., Black, A.D., and W.F. Brace, "Friction and Deformaation of Jcinted Quartz Diorite". Proceedings Third Int. Cong. on Rouk Mechanics, Denver, Colo. 1974.

Ramspott, L.D., et a1, "Technical Concept for a Test of Geologic Storage of Spent Reactor Fuel in the Climax Granite, Nevada Test Site", UCRL-52796, June 15, 1979.

Richter, D., and G. Simmons, "Thermal Expansion Behavior of Igneous Rocks", Int. Journal of Rock Mechanics and Mining Science, VII, p. 403-411, 1974.

Robertson, E.C., "Viscoelasticity of Rocks", State of Stress in Earth's Crust (Santa Monica Conference), Elsevier, New York, 9664.

Rodrigues, F.P., "Anisotropy of Granites", 2nd Int. Congress on Rock Mechanics, Belgrade, 1970.

Schock, R.N., and H.C. Ieard, "Static Mechanical Properties and Shock sading Response of Granite", JGR, V. 79, nIl, pp. -t. $<-1666,1974$.

Schock, R.N., Heard, H.C., and D.R. Stephens, "Stress-Strain Behavior of a Granodiorite and Two Graywackes on Compression to 20 kilobars", JGR, V78, n26, pp. 5922-5941, 1973.

Simons, G. and H.W. Cooper, "Thermal Cycling Cracks in Three Ifneous Rocks", Irt.. Journal of Rock Mechanics and Mining Science, V. 15, 1978. 
Skinner, B. J., "Therwal Expansion", Handbook of Physical Constants, Memoir 97, GSA, 1966.

Swan, Graham, "The Mechanizal Properties of Stripa Granite", LBL 7074. August, 1978.

Thirumalai, R., "Rock Fragmentation by Creating a Ihermal Inclusion with Dielectrjc Heating", USBM RI7424, 1970.

Touloukian, Y.S., Thermophysical Properties of Matter, V12: Thermal Expansion 1975.

Tsui, K.K., "A Study on the Thermomechanical Stabllity of Rock Caverns", Report No. 78239, Ontario Hydro (Geotechnical Engineering Dept.), 1979.

Tullis, J., and R.A. Yund, "Experimental Deformation of Dry Westerly granite", JGR, Vol. 82, in 36, pp. 5705-5718, 1977.

Van der Molen, I., A Note on the Thermal Expansicn of Granite at Hi, ?ressure and on the Associated Shift in the $A \sim B$ Transition of Quartz, Ph.D. Diss., Australian Nat. Univer., Canberra, 1979.

Wawersik, W. R., "Time - Dependent Behavior of Rock in Compression", Proceedings Third Int. Cong. on Rock Mechanics, Denver, Colo., 1974.

Wingquist, C.F., "Elastic Moduli of Rock at Elevated Temperatures", USBM RI7269, 1970.

Witherspoon, P.A., et al, "Rock Mass Characterization For Storage of Nuclear Waste in Granite", LBL 8570, Feb, 1979.

Wong, T.F., and Brace, W.F., Thermal Expansion of Rocks: Some Measurements at High Pressure, Tectonophysics (in press), 1979.

Wu, F.T., and L. Thomsen, "Microfracturing and Deformation of Westerly Granite Under Creep Condition", IJRM, June, 1975. 
HYDROLOGY OF GRANITES

$1-128$ 


\subsection{INTRODUCTION TO HYDROLOGY OY GANITES}

Contact of radioactive waste with ground waters and subseque:t transport by ground waters is thought to be one of the few ways radioactive materials in a repository may commicate with the biosphere. Consequently, accurate identification of those parameters controlling ground water flux and velocity coupled with representative modeling and field testing of the ground water environment is critical to the identification of appropriate repository sites. A sumary of measured values $\mathrm{f}_{\mathrm{c}}$ : various hydrologic parameters may be found in Appendix A.

This section begins with a discussion of the fundamentals of groundwater flow through porous media. Presented is a discussion of groundwater flow through single fractures, fracture networks, and regional flow systems. The section is concluded with a sumary of the effects of temperature on the hydraulic characteristics of a rock mass and a discussion on hydraulic dispersivity. 


\subsection{FUNDAMENTALS OF GROUND WATER FLOW}

Ground water flow through both intergranular and fractured media is based upon the same fundamental concepts. To understand flow in either medium, it is necessary to be familiar with Darcy's law, the various methods of presenting permeability and porosity and the equations leading up to the general ecuation of flow in isotropic homogeneous materials.

\section{Darcy's Law and Permeability}

The fundamental relationship describing flow through a porous media is Darcy's law. This law is an empirical relationship which describes laminar flow through an isotropic and homogeneous medium. In its simplest form, Darcy's law describes ground-water flow as follows:

$$
Q=K A \frac{d h}{d I}
$$

where:

$Q \quad$ is rate of flow $\left(\mathrm{m}^{3} / \mathrm{sec}\right)$

A is the cross sectional area of the medium $\left(m^{2}\right)$

$\mathrm{K} \quad$ is hydraulic conductivity ( $\mathrm{m} / \mathrm{sec}$ )

$\frac{\mathrm{dh}}{\mathrm{dl}}$ is hydraulic gradient (non-dimensional)

Hydraulic conductivity is a measure of the ability of a fluid at a specific temperature to pass through a medium. It is a function of properties of the medium as well as of the viscosity and specific weight of the fluid. Many ground vater texts utilize hydraulic conductivity with the assumption that the fluid is water at a 
temperature of $20^{\circ} \mathrm{C}$. In applications where fluid parameters are not constant, some authors prefer to utilize intrinsic permeability (k), expressed in units of $\mathrm{m}^{2}$. Intrinsic permeability is a function of medium properties and is independent of properties of the fluid. Intrinsic permeability is related to hydraulic conductivity by the following relationship:

$$
\mathrm{K}=\frac{\mathrm{kg}}{\mathrm{v}}
$$

where:

$$
\begin{aligned}
& \mathrm{g} \text { is acceleration of gravity }\left(\mathrm{m} / \mathrm{s}^{2}\right) \\
& \vee \quad \text { is kinematic viscosity ( } \mu / \mathrm{p} \text { in } \mathrm{cm}^{2} / \mathrm{sec} \text { ) } \\
& \rho \quad \text { is fluid density ( } \mathrm{g} / \mathrm{cc} \text { at specific temp) } \\
& \mathrm{H} \quad \text { is absolute viscosity ( } \mathrm{g} / \mathrm{cm} . \mathrm{sec} \text { ) }
\end{aligned}
$$

Another related parameter, transmissivity, is often utilizet in discussions of ground water movement. Transmissivity, expressed in units of area per unit time $\left(1^{2} / \tau\right)$ is defined as the rate at which water of a prevailing kinematic viscosity is transmitted througl. a unit width of the entire aquifer under unit hydraulic gradient. Transmissivity (T) is related to hydraulic conductivity as follows:

$$
\mathrm{T}=\mathrm{K} 1
$$

where:

$$
1 \text { is aquifer thickness }
$$

\section{Porosity and Storativity}

Total porosity is defired as the ratio of the aggregate volume of interstices in a rock to its total volume. Included in the determination of true porosity are isolated vugs, microfractures and ciscontinuous volds which do not contribuce to grouni witer flow, 
Effective porosity is defined as the ratio of the volume of wat $\in \mathrm{T}$ which can be put in motion under the effect of gravity forces to the total volume of rock (Battelle, 1979). Effective porosity is that portion of the void which actively contributes to ground water flow, and consequently it is of more significance in hydrologic evaluations than is total porosity.

Closely related to porosity is aquifer storativity, which is the abiiity of an aquifer to retain and release waters. Specific yield (Sy) is a dimensionless measure of storativity expressed as the ratio of the volume of wat: which an aquifer, after being saturated, will yitld by gravity to its own volume. Storage coefficient (S) is defined as "the volume of water an aquifer releases from or takes into storage per unit surface area of the aquifer per unit change in the component head normal to the surface" (Todd, 1967).

For an unconfined aquifer, the storage coefficient is equivalent to its specific yield. In a confined aquifer, water is not released by gravity drainage, but rather, storage releases are derived from the small expansion of water as the head declines and from compaction of the aquifer itself. Storage coefficients for unconfined aquifers are related to porosity and will have decimal values slighicly less than porosity. Storage coefiicients of confined aquifers are not directly related to porosity and may range from $10^{-3}$ to $10^{-6}$. 


\section{Ground Water Velocity}

Although hydraulic conductivity bears units of velocity $(1 / t)$, this does rot represent the true rate of particle movement. Many authors utilize "Darcian velocity" in their discussions. This represents the pioduct of the aydraulic conductivity and ground water gradient. For a material of less than unit porosity, this again is not representative of particle velocity. Darcy velocity may be obtained by dividing both sides of the Darcy relationship, $Q=K A \frac{d h}{d I}$ by area, . However, flow comes only from that portion of the area which is pore space, or At ritere $A$ is effective porosity. The average particle velocity is consequently the Darcy velocity divided by effective porosity:

$$
\mathrm{V}=\left(\mathrm{K} \frac{\mathrm{dh}}{\mathrm{dI}}\right) / \theta
$$

where:

$V$ is average particle velocity

$\theta$ is effective porosity

The "seepage" velocity derived from this equation is a vector average velocity. It does not represent the range of particle velocities in the rock mass. Consequently, "seepage" velocity should be used only. with appropriate assumptions when describing particle migration.

\section{General Flow Equation}

In order to model three dimensional flow in a homogeneous, isotropic system, a general equation describing ground water movment was developed. This equation can be derived directly from Darcy's equation

$$
Q=R A \frac{d h}{d I}
$$


the equation defining storage coefficient

$$
S=\frac{1}{A} \frac{d v}{d h}
$$

where $v$ is volume and the equation of continuity (conservation of mass)

$$
\text { inflow - outflow = storage }
$$

The general equation for unsteady state flow in a confined aquifer is:

$$
\frac{\partial^{2} h}{\partial x^{2}}+\frac{\partial^{2} h}{\partial y^{2}}+\frac{\partial^{2} h}{\partial z}=\frac{S}{I} \frac{\partial h}{\partial t}
$$

or

$$
\nabla^{2} h=\frac{S}{T} \quad \frac{\partial t}{\partial t}
$$

For steady state flow or for unconfined unsteady state flow, the term $\frac{S}{T} \frac{\partial h}{\partial t}$ may be neglected (Davis and Dewiest, 1970) and the general equation becomes:

$$
\nabla^{2} \mathrm{~h}=0
$$

or Laplace's equation.

This equation, or modifications of it, serve as the basis for many of the finite element models of ground water systems currently being utilized. 


\subsection{GROUND WATER FLOW THROUGH SIMGLE FRACTURES}

A granite chosen as a host rock for a nuclear waste storage facility will have a groundmass with negligible permeability. The only significant method of ground water transport through such a rock mass will be by means of flow through unfilled fractures. Although Darcy's law was developed fiom observations made on materials with intergranular porosity, the relationship may be extended to describe fiow in a fracture in an effectively nonpermeable rock mass. This extension of Darcy's law was first proposed in a thesis by Snow (1965). Snow concluded that laminar flow through fractures is analogous to flow between smooth parallel plates. Based upon this parallel plate model, he determined that hydraulic conductivity may be expressed by:

where:

$$
K=\frac{\rho g(2 b)^{2}}{12 \mu}
$$

$2 b$ is fracture aperture.

Intrinsic permeability can consequently be expressed:

$$
\mathrm{k}=\frac{\mathrm{g}(2 \mathrm{~b})^{2}}{12 \mathrm{v}}
$$

Now relating this back to Darcy's law, an equation describing the flow rate per unit width in a single Eracture $q$, can be written:

$$
q=\frac{g(2 b)^{3} \frac{d h}{d I}}{12 v}
$$

This relationship, demonstrating discharge to be proportioned to the cube of fracture aperture, is known as the cube law. This law confirms that only slight changes in aperture can cause large changes in flow and is a key to modeling flow in a fractured aquifer. Corraspondingly, average velocity may be expressed:

$$
V=\frac{1 . g(2 b)^{2} \frac{d h}{d I}}{12 \mu}=k \frac{d h}{d I}
$$


The area considered in determining velocity of flow is the cross sectional area of the fracture, and the porosity of the open $f_{i}$ acture is unity. Table 1-24 illustrates the hydraulic conductivities and the average velocities that result from equations 1-10 and 1-13 for a range of apertures and assuming water at ambient conditions under a hydraulic gradient of .001 .

As flow velocities increase, roughness of the fractures will cause turbulence and non-uniform flow with'n the fracture plane. Louis and Maini (1970), Sharp and Maini (1972) and Gale (1975) have investigated nonlinear, non-Darcian flow through an "equivalent" aperture. The equivalent aperture will be that of a parallel plate model having the sane hydraulic behavior as the natural fracture.

Gale ran double set packer tests on single fractures in a borehole. Utilizing a constant head, he was able to measure the rate at which a single fracture would take water. With this information, he utilized a form of the cube law to salculate equivalent aperture. A summary of Gale's work, Table 1-25, shows the calculated, equivalent apertures to differ with the true (measured) apertures by at least an order of magnitude, the true aperture being larger. Because roughness of fracture walls and non-uniform flow within the fracture plane are very difficult to evaluate directly, the concept of equivalent apertures is very significant in current approaches to modeling. 
Table 1-24. Hydraulic conductivity and velocity for water flowing through a single fracture

\begin{tabular}{|c|c|c|c|}
\hline \multirow{2}{*}{$\begin{array}{c}\text { Aperture } \\
\text { b } \\
\text { microns }\end{array}$} & \multirow{2}{*}{$\begin{array}{l}\text { Hydraulic } \\
\text { Conductivitiy, } x \\
\text { I. } \sec ^{-1}\end{array}$} & \multicolumn{2}{|c|}{ Effective veiocity, $v$} \\
\hline & & m. $\sec ^{-1}$ & $k m \cdot$ year $^{-1}$ \\
\hline $\begin{array}{r}0.1 \\
1.0 \\
10.0\end{array}$ & $\begin{array}{l}8.2 \times 10^{-9} \\
8.2 \times 10^{-7} \\
8.2 \times 10^{-5}\end{array}$ & $\begin{array}{l}8.2 \times 10^{-12} \\
8.2 \times 10^{-10} \\
8.2 \times 10^{-8}\end{array}$ & $\begin{array}{l}2.6 \times 10^{-7} \\
2.6 \times 10^{-5} \\
2.6 \times 10^{-3}\end{array}$ \\
\hline
\end{tabular}

Source: Apps et al, 1968 
TABLE 1-25. Fracture data and equivalent fracture apertures for selected Eractures at Sambro, Nova Scotia.

\section{Fracture Depth}

Mode1

(m)

Borehole

(m)

$3.05 \quad 2.85$

$3.96 \quad \ldots .020$

5.03

5.063

6. 10

6.117

B. 53

8. 806

10. 2

7.315

12. 2

12. 50

SOURCE: Gale, 1975

\section{Aperture estimated}

from Borehole

periscope log

(m)

$$
\begin{aligned}
& .030-.024 \\
& .0030-.0061
\end{aligned}
$$

.0015

$.0015-.0030$

$.0015-.0030$

.0015

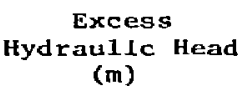

(m)

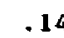

3.8

5.28

15.7

22.9

177

4.02

7.59

6.05

12.7

3. 097

7.251

7.102
FIow Rate

(cfs) $\times 10^{+3}$

4.46

.98

1.12

.027
.45

.67

1.29

1.56

1.29

1.87

.003

.005

0.001
Calculated

Equivalent

Apertures

(m)

0011

.00021

.000207

.00004

.00009

.00026

.00024

.00021

.000207

.00019

.000034 .000030

.000046 


\subsection{FRACTURE NETWORKS}

Many parameters have a bearing on the rate of ground water flow through a fracture network. Fracture spacing, aperture sizes, orientation, and continuity are among the most significant factors. Also of importance is the roughness of fracture walls, wall coatings, fracture fillings and the degree of uniformity of apertures.

\section{Joint \& Fracture Systems}

Early research in granitic tectonics conducted by Hans Cloos (Kendorski and Mahtab, 1976) identified an orthogonal system of joines which is characteristic of nearly all granitic plutons. Cloos identified this or thogonal joint system as consisting of $Q, S$, and L fracture systems.

Q-fractures or aross-joints were determined to result from extensive fracturing parallel to the principal direstion of stress in the rock mass.

S-joints or longicudinal fractures formed parallel to the flow lines or crystal orientation and result from failure along the anisotrophy resulting from the flow.

L-joints are Elat-lying joints resulting from variations in vertical loading or rebound. 
Although later tectonic activity may superimpose additional fracture systems on a granitic mass, nearly all possess the primary set of orthogonal joints icientified by Cloos. Subsequent authors (Price, 19t6), confirm the basic concepts of Cloos; however, Price proceeds to conclude that joints have little hydraulic significance. Prite proposes hat hrittle fractures resulting from unloading and uplift are of the most significance to ground water flow.

\section{Vai iation In Aperture and Fracture Spacing}

Snow (1965, 1968, 197 ), Lewis and Burgy (1964), UhI and Sharma (1978) and others concur that the permeability and fracture porosity of crystalline rocks decrease with depth and that the rocie type is of less importance in describing these parameters than is fracture geometry. F-acture spacings are found to generally increase with depth, while fracture openings generally decrease. Snow (1968), in studies of crystalline rock at four dam sites in Colorado, found fracture spacings at the weathered surface to range irom .15 to 1.2 met urs and found spacings to increase to 1.5 to 4.6 meters immediately beneath this surface. Fracture spacings were found to further increase to 5 to 11 meters at depths of 61 meters. Effective apertures inferred from packer tests were observed to range from 75 to 400 microns in the upper? meters of the rock mass and to decline to 50 to 100 microns at depths of 15 to 61 meters as shown on Figure 1-42. 


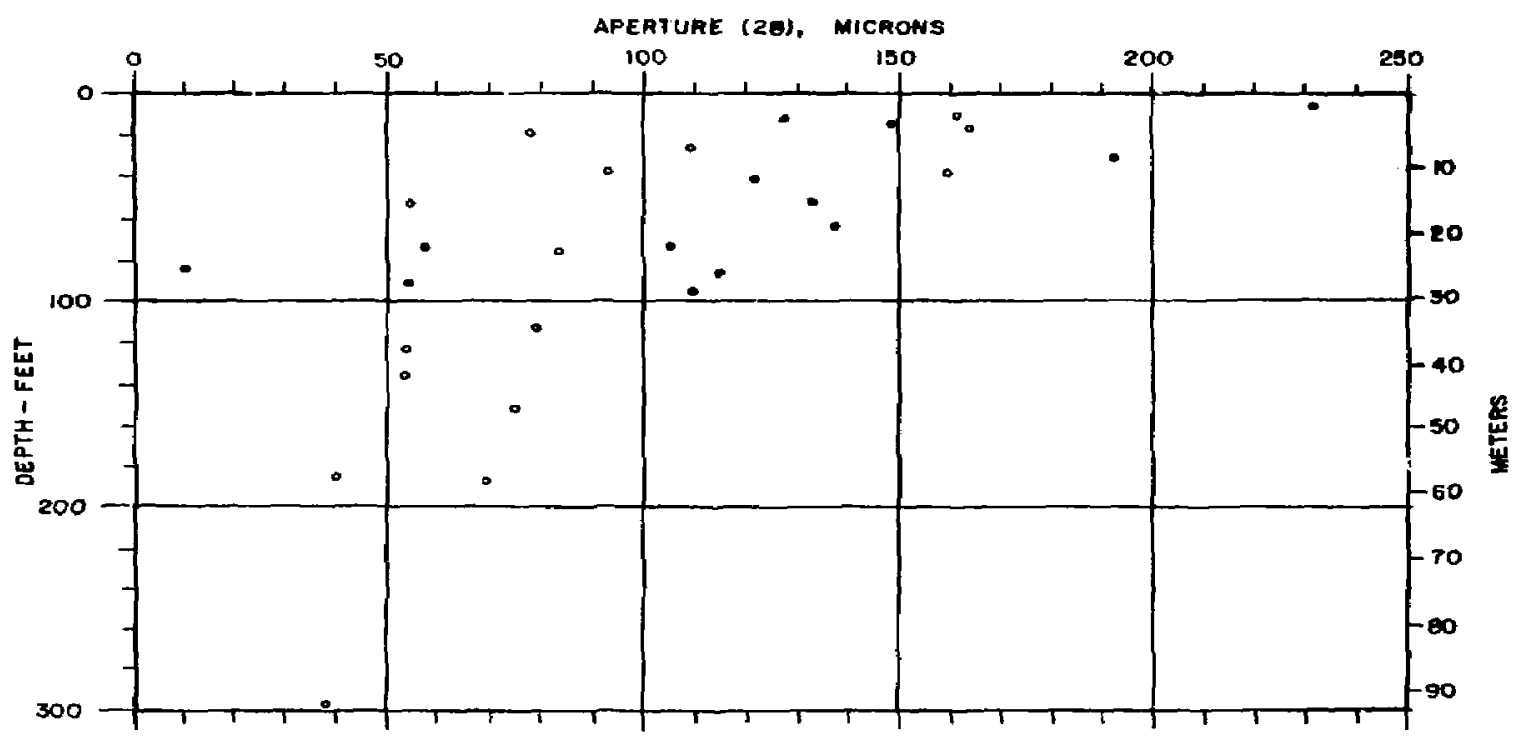

FICURE 1-42 Fracture openings In the gneisses of the Front Range, Colorado, computed

from injection tests

source: Snow, $1968 b$ 
Corresponding to the observed changes of fracture spacing and aperture sizes with depth in Dr. Snow's studies is a decline in both fracture porosity and permeability. Fracture porosity is found to decline from $.05 \%$ near the surface to approximately $.0005 \%$ at 122 meters, and it is generalized that fracture porosity decreases at a rate of approximately an order of magnitude per 61 meters of depth (Snow, 1968a). Permeability measured at equivalent depths at the four dam sites varied; however, all followed a logarithmically declining trend with depth.

Utilizing data from the four dam sites, Snow (1971) suggests a technique for estimating the permeability of a fractured crystalline rock mass. By nlotting the mean permeability of each depth zone against mean depth, Figure 1-43, and constructing a line through these points by means of a least-square fit, Snow concludes that permeability varies with depth relative to the following equation:

$$
\log k=-8.9-1.67 \log d
$$

where:

$k$ is intrinsic permeability $\left(\mathrm{Ft}^{2}\right)$

$d$ is depth below the surface of the rock mass measured in feet

Research conducted in Sweden concludes that permeability declines somewhat more rapidly with depth along an exponential curve (ONWI, 1978b). Laboratory work with fractured granite in artificial stress fields (Pratt et a1, 1971) correlates somewhat more closely with the conclusions of Snow; however, this research considers only declining 


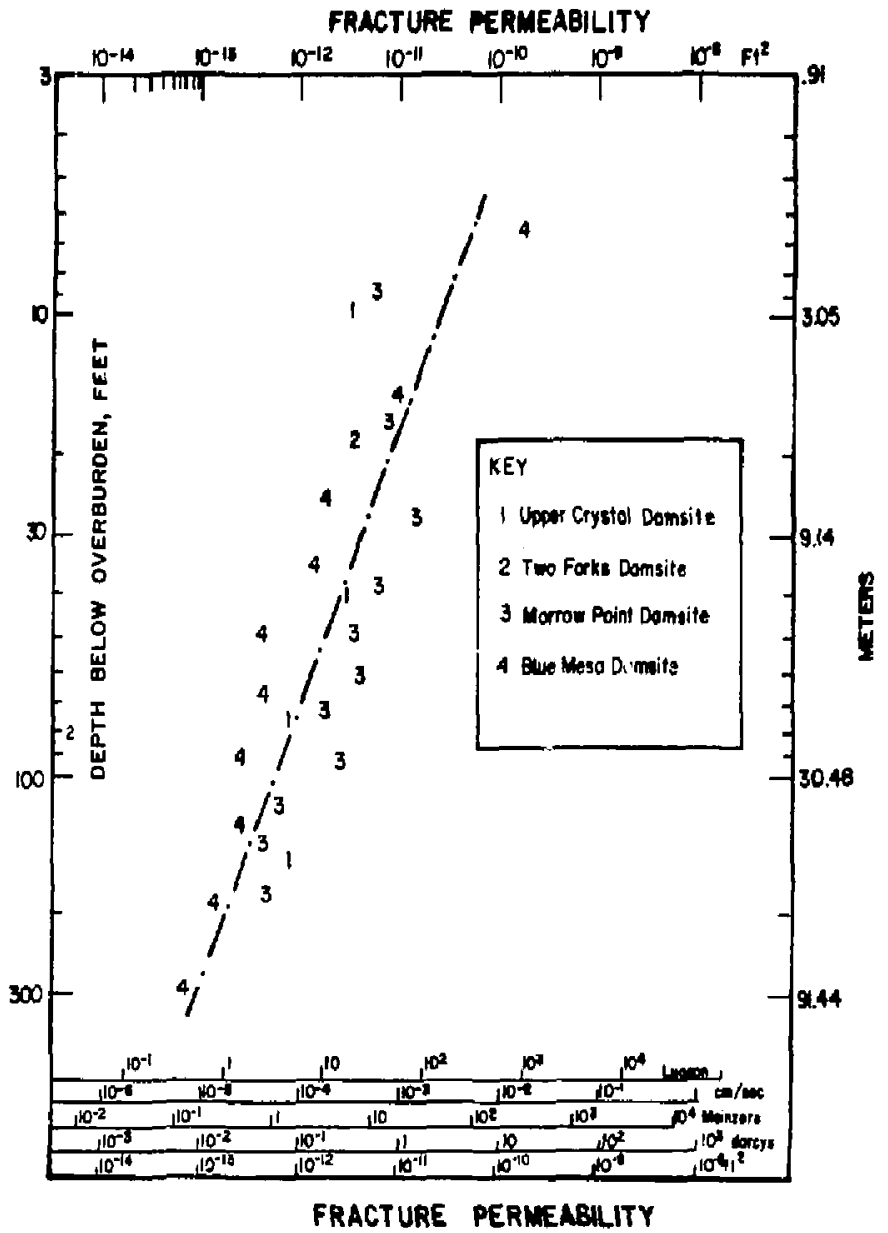

FIGURE 1-43 The mean permeability in exch depth zone at 4 dansites $v 5$ the mean depth of mid-points of test sectlons. Source: Snow, 1968. 
fracture density with depth. At depths exceeding 450 meters, the validity of either relationship is uncertain. Pratt suggests that

fracture permeability asymtotically approaches a value approximately one order of magnitude greater than the permeability of the rock matrix as normal stress increases.

The fracture porosity of a rock mass with a specific permeability is dependent upon the fracture geometry and fracture aperture. Snow concludes from his work on the four Colorado dam sites that an orthogonally fractured rock mass at a specific depth with uniform fracture openings will have a porosity which is related to fracture spacing by the following relation:

$$
\theta=3(3 \mathrm{k} / 2)^{1 / 3}(2 / \Delta)^{2 / 3}=5.45\left(\mathrm{k} / \Delta^{2}\right)^{1 / 3}
$$

where:

$$
\begin{aligned}
\theta & =\text { effective porosity } \\
k & =\text { permeability }\left(\mathrm{ft}^{2}\right) \\
\Delta \quad & =\text { fracture spacing (ft) }
\end{aligned}
$$

The apparent spacings of individual fractures within each of three assumed orthogonal sets of water bearing fractures as observed at the Colorado dam sites is sumarized on Figure 1-44. In the work by Snow, it is assumed that fracture spacings are normally distributed. More recent work by Priest and Hudson (1976) suggests spacing is exponentially distributed. The effect these differences in distribution will have on resultant permeability and porosity has not been specifically evaluated. 


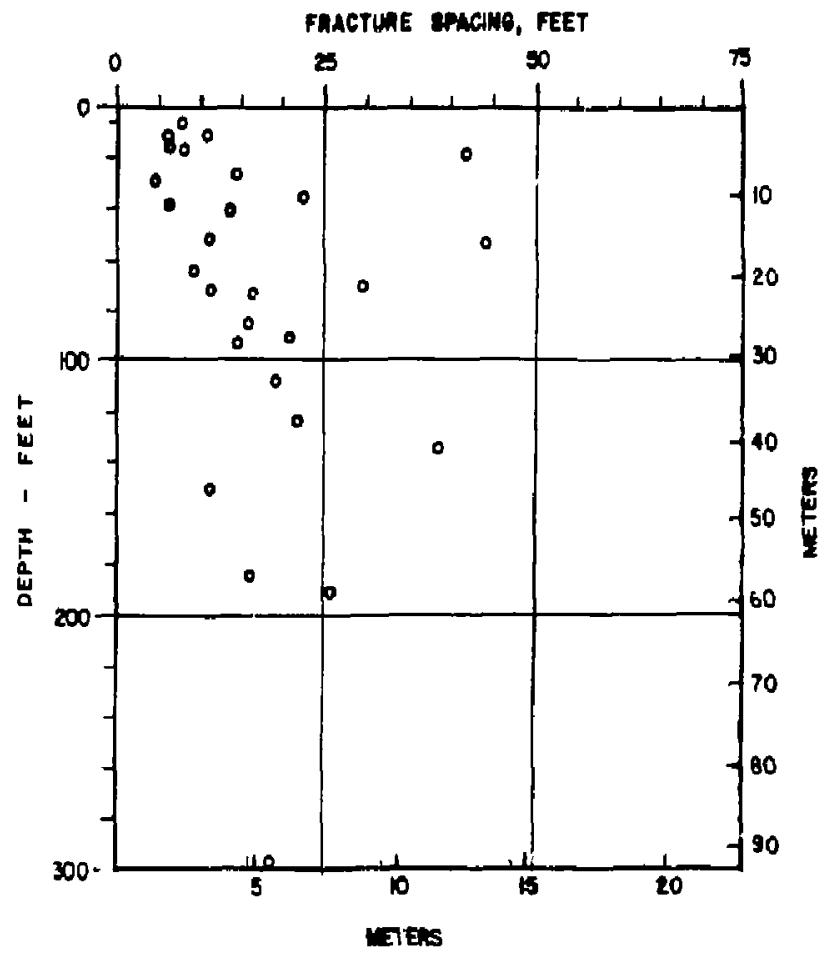

FIGURE 1-44 Apparent spactng of Individuals of each of three assumed orthogonal sets of vaterbearing fractures at four dam aites in gneisses of the Front Range, Colorado, computed frow injection tests

Source: Snow, 1968. 


\section{Effects of Stress on Fracture Permeability}

It is generally accepted that stress can have a large effect on the permeability of rock. A decrease in permeability with depth as demonstrated by Davis and Turk (1964) and Show (1968) is often considered to be stress related. There has, however, in recent years, developed some disagreement among authors as to whether decreasing permeability with depth is due in greater degree to decreasing aperture size or increasing fracture spacing. Raven and Gale (1976) and Kendorski and Mahtol (1976) indicate aperture decreases with depth while fracture geometry remains constant. Conversely, Swedish investigators on the Stripa project conclude that fractures with significant apertures persist to depth but that spacing increases (Battelle, 1978).

Work by Iwai (1976) on man-made fractures in basalt, granite and marble generally supports the concept of decreasing aperture. Under normal stresses ranging from 0 to $20 \mathrm{MPa}$, Iwai found both aperture and hydraulic conductivity to decrease with increased stress. However, a minimum hydraulic conductivity was found to be approached asymptotically as stress was increased. Imperfect matching of opposing surfaces caused apertures to approach 15 microns as normal pressures approached $20 \mathrm{MPa}$.

Recent work by Brace (1979) to some degree contradicts the accepted concepts of declining permeability with depth. Brace assembled laboratory and in situ permeability measurements from a number of 
locations and presented this data in the form of a histogram, see Figure 1-45. Utilizing this data, Brace makes the following observations:

a) The average $k$ of the more permeable crystalline rocks is about $10^{3}$ greater than corresponding laboratory measurements. This variance is due in part to the dependence of permeabilily measurements on sample size in laboratory determinations.

b) There is a hint of decrease of permeability with depth but hardly enough to justify the exponential relationships suggested in the literature.

c) At near'y every site some portion of the rock sanpled by the drill holes has a permeability of 1 to $100 \mathrm{md}$. This relatively permeable zone may be as deep as $3.3 \mathrm{~km}$.

Given the square relationship between flow velocity and aperture size, it is particulariy critical to define, at least on a site specific basis, the relationship between aperture size and depth.

\section{Orientation And Continuity of Fractures}

In many fractured crystalline bodies, a variation in average aperture with fracture orientation is observed. Given the cube relationship between aperture and flow, it can be seen that the orientation of large fractures with respect to the potential gradient makes a major 


\section{LABORATORY \\ MEASUREMENTS}

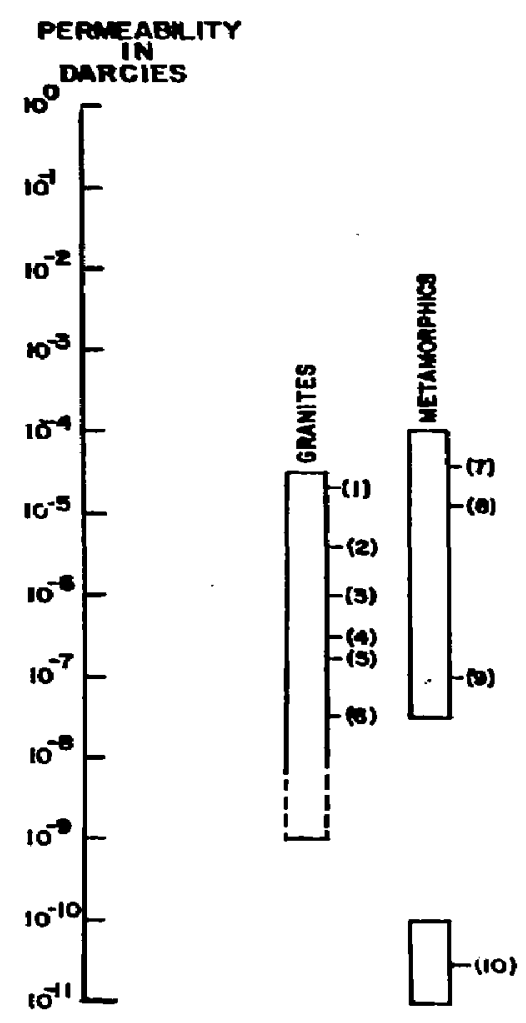

䓌

\section{IN SITU TESTS}
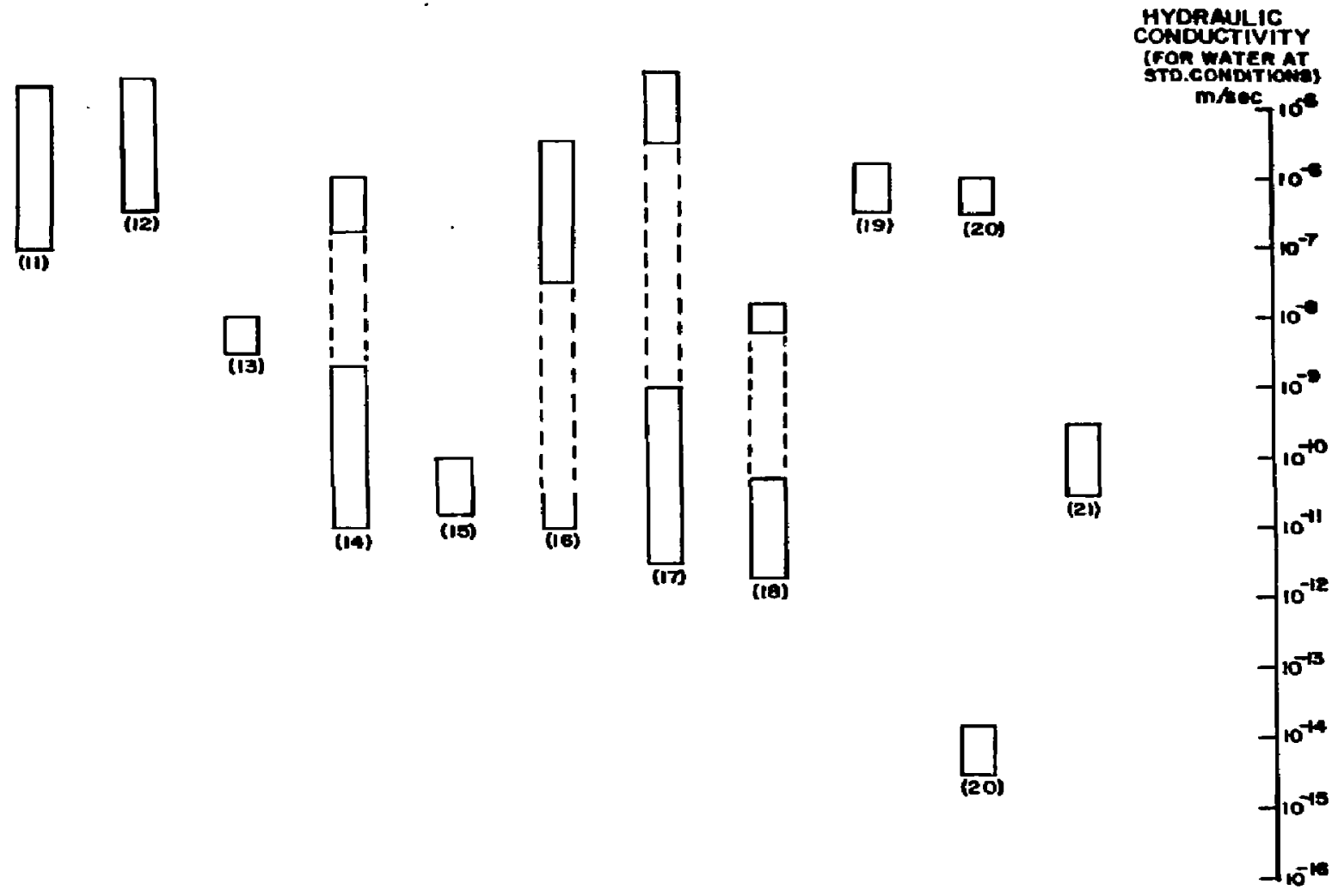


\begin{tabular}{|c|c|}
\hline $\begin{array}{l}\text { Determination } \\
\text { No. }\end{array}$ & Rock Type \\
\hline 1 & Laramie Granite \\
\hline 2 & Quincy Garnite \\
\hline 3. & Hesterly Granite \\
\hline 4. & Sample from Los Alamos, New Mexico \\
\hline 5. & Barre Granite \\
\hline 6. & Ontario Granites \\
\hline 7. & Front Range Gneiss \\
\hline 8. & Front Range Schist \\
\hline 9. & Quartzite \\
\hline 10. & White Lake Gneis: \\
\hline 11. & Metamorphics - Colorado Front Range (well tests) \\
\hline 12. & Crystalline rock at 38 western damsites \\
\hline 13. & Laramie Granite - well test \\
\hline 14. & Crystalline basement rock - pump test from Alken, S.C. \\
\hline 15. & Stripa Grantte - pumping tests \\
\hline 16. & Granites and Gneiss - 500 pumping tests - Sweden \\
\hline 17. & Lac du Bonnet batholith - pumping tests, Pinawa, Manitoba \\
\hline 18. & Granodiortte - pumping tests - Los Alamos, New Me:.ico \\
\hline 19. & $\begin{array}{l}\text { Crystalline basement - injection tests - Rocky Mt. } \\
\text { Arsenal, Denver }\end{array}$ \\
\hline 20. & Climax granitic stock - pressure decay tests \\
\hline 21. & Quartzize \\
\hline
\end{tabular}

FIGURE 45 (Cont.) Key to Rock Types 
difference in ground water flow velocity and direction. The definition of orientations of fractures is critical to the determination of anisotropic permeability.

The results of fracture mapping in many geologic environments have shown that fractures cannot be assumed to be continuous within their own planes (Apps et al, 1979). Continuity is the most difficult of the fracture parameters to measure in situ. However, defining the continuity of fractures is of prime importance in describing ground water movement. Long duration well tests that affect large volumes of rock and single fracture cross-hole tests are currently most widely utilized for determinations of fracture continutiy.

\section{Fracture Network Flow}

Equations describing flow through a fracture network can be developed from the fllow equation for a single fracture:

$$
v=k \frac{d h}{d I}
$$

For anisotropic conditions in a rockmass, the equation can be modified:

$$
\{V\}=[k p]\{i\}
$$

where:

\{v\} is the velocity vector

(i) is the potential grodient vector

[kp] is a second order tensor formed from the permeability terms of each fracture set. 
The derivation is continued by Apps et al (1979) by defining area permeability (kp) in terms of gradient and flow rate per unit area $(\$ A)$ :

$$
q A=k p i
$$

For a set of fractures with a frequency $\lambda$, the single fracture permeability, $k$, san then be related to area permeability, kp, by:

$$
[\mathrm{kp}]=2 \mathrm{~b} v[\mathrm{k}]
$$

Assuming a uniform set of fractures oriented in the $x-y$ plane with aperture $2 b$,

$$
\left[\mathrm{Kp}_{j}\right]=2 \mathrm{~b} \lambda\left[\begin{array}{ccc}
\frac{g(2 b)^{2}}{12 v} & 0 & 0 \\
0 & \frac{g(2 b)^{2}}{12 v} & 0 \\
0 & 0 & \frac{g(2 b)}{12 v}
\end{array}\right]=\left[\begin{array}{ccc}
\frac{\lambda g(2 b)^{3}}{2 v} & 0 & 0 \\
0 & \frac{\lambda g(2 b)^{3}}{2 v} & 0 \\
0 & 0 & \frac{\lambda g(2 b)^{3}}{2 v}
\end{array}\right]
$$

The principal permeabilities and their orientations are the eigenvalues and eigenvectors of the permeability tensor formed from the combination of the tensors of the individual fractures (Apps et al 1979). A detailed summary of the derivation of permeability tensors from single fracture data may be found in Bianchi and Snow (1969). Although $k$ almost certainly varies with direction in rocks, principal values of the permeability tensor are rarely given (Brace, 1979). Network flow studies utilizing the permeability tensor are, to date, principally theoretical and have little field conformation. 


\subsection{REGIONAL GROUND WATER FLOW}

While fluid flow through individual fractures is well understood and flow through fracture networks has been theoretically proposed, ground water flow on a regional scale is only beginning to be investigated.

\section{Fundamental Regional Flow Characteristics}

In a granite drainage basin, ground water movements will vary laterally and vertically in the various fracture networks that interface to allow ground water flow through the region. In general, water will be recharged into the country rock in topographically lower areas. In the recharge area, the direction of water movement is principally downward, the depth of penetration depending upon fracture geometry, continuity and numerous other geologic parameters. Ground water flow eventually becomes roughly horizontal until a zone of discharge is reached where the flow lines turn upward. The distance between recharge and discharge points in a granite drainage basin may range from only a few tens of meters to many kilometers,

In many granite drainages, the water table roughly parallels surface topography. Water table configuration, and hence topography, often controls the locations of recharge and discharge zones. As demonstrated on the flow nets of Figure 1-46, the size of recharge and discharge zones will vary depending on their position and the degree of topographic relief in the basin (Apps et al, 1978). 


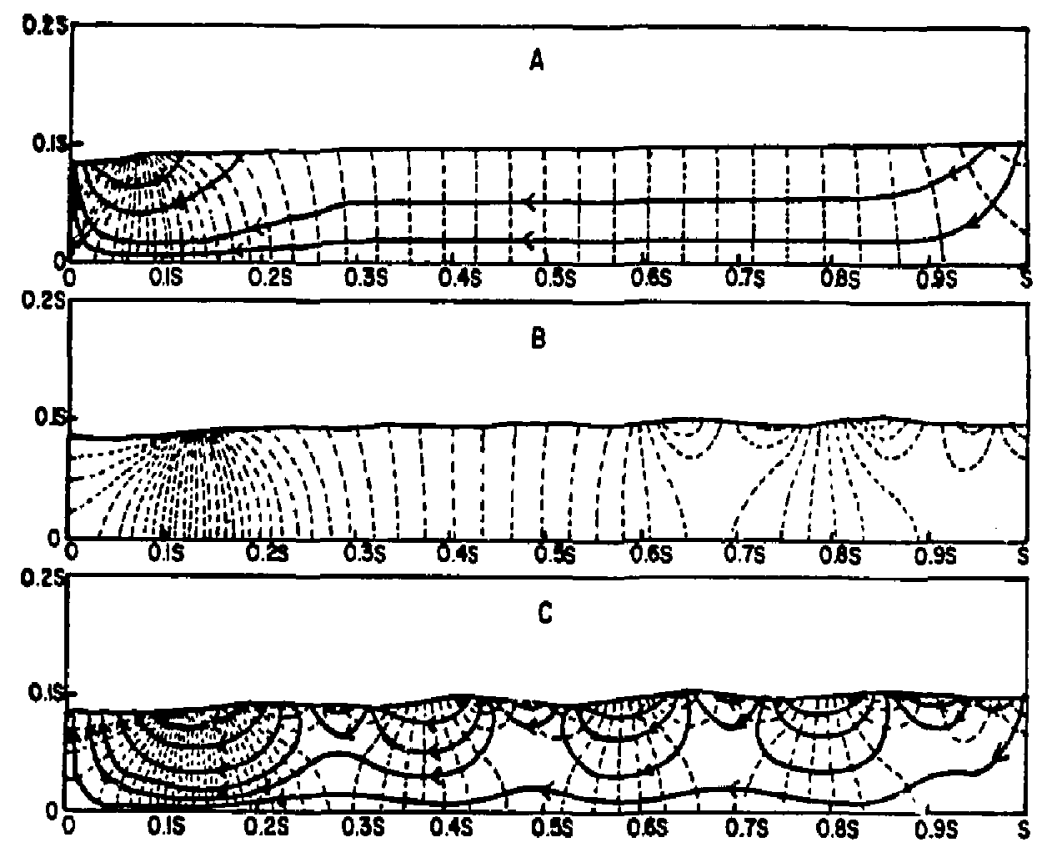

FICURE 1-46 Effect of watet-table configuration on reg1 nnal groundwater flow through homogeneous inotropic media. Source: Freeze and Wtherspoon, 1967. 
Regional ground water flow may also be interrupted by geologic anomalies such as faults or shear zones. These features occur on scales from a few meters in length to tens of kilometers. If the fractures associated with these features are open, they may channelize ground waters and cont-ol the sovements of both surface and ground waters within a besin. Such features have been observed carrying significant ground water flows at depths in excess of $3.5 \mathrm{~km}$. (Brace, 1979) (Robizson, 1978). Often, however, faults and shear zones are filled with rubole which has undergone extensive chemical or mechanical alteration producing a clay rich materlal of very low permeability known as fault geuge. In areas where fractures and voids associated with faults or shear zones are filled with gouge, or other fines or precipitates, the feature may act as a barrier to ground water flow.

It is anticinated that a repository would not be sited in a granite body at a location significantly dissected by faults or shears. Rather, a repository would probably be sited in a recharge zone of a deep geologic str ..ure with a low fracture permeability. The site should be chosen to maximize ground water flow paths to the surface and thus maxi.nize the underground residence time of waters leaving the repository.

\section{Layer Models of Regional Systems}

Various authors have atteu, ted to identify different horizons in the crystalline aquifer to simplify descriptions of ground water flow. Hurr and Richards (1974) broke the aquifer down into an active zone 
and a passive zone. The active zone is defined as that near-surface, weathered zone in which the water table is subject to seasonal fluctuation, and significant flows may be observed. The passive zone is defined as an underlying zone of lower permeability in which wate: may be stored for tens to thousands of years. In research at the Straight Creek Tunnel in Coloraco, the contact between the active and passive zones was found to fluctuate in depth; however, it was identified as the point at which the seismic velocity increased from $3780 \mathrm{~m} / \mathrm{sec}$. to approximately $5400 \mathrm{~m} / \mathrm{sec}$.

In modeling studies for the Office of Nuclear Waste Isolation (1978b), three zones of saturation were considered. The upper zone was identified as that of the highest permeability, holding young waters containing both Carbon 14 and tritium. The intermediate zone was identified as that bearing water of intermediate age containing Carbon 14, but lacking tritium. The deepest and least permeable zone was identified as containing the oldest water which bears no measurable tritium or Carion 14.

Either technique for identifying specific horizons in the crystalline aquifer can be a simplification of cume assistance in modeling. However, the boundaries between these horizons are of ten quite gradational and difficult to specifically define in the fiald. 


\section{Representative Elementary Volume}

Regional evaluation of ground water systems is currently often approached by continuum modeling. This technique requires that representative values be assigned to parameters for a finite volume element. Consequently, some technique must be developed for establishing representative values from field data. Bear (1972) has proposed the concept of representative elementary volume (REV). As illustrated on Figure 1-47, the representative elementary volume $\left(u_{0}\right)$ is that volume at which small additional increased in volume will have no significant effect on the value of the parameter measured.

For volumes smaller than the REV, discrete fracture effects will influence the value of the parameter as the test volume is increased by small increments. However, for a volume equivalent to or larger than the REV, we move into the domain of porous media effects (Battelle, 1979). A list and summary of some of the models currently being utilized for regional flow analysis are presented in Battelle (1979). 


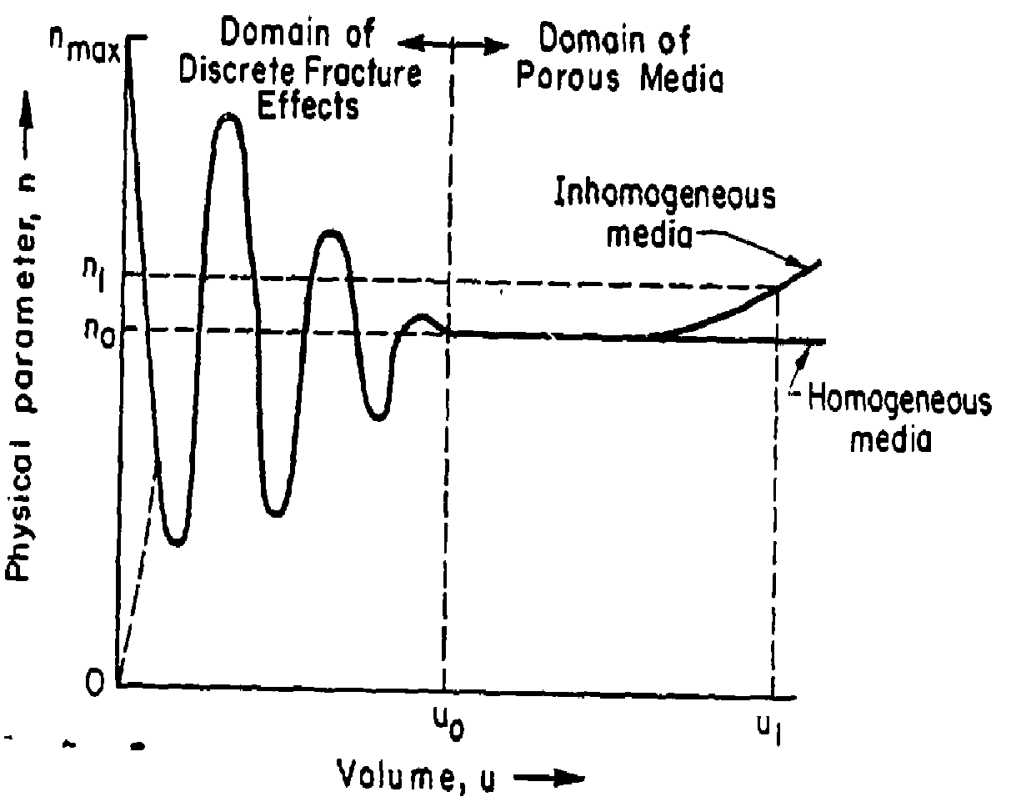

XBL 7811-6115

FIGURE $1-47$

Definition of a representative elementary yolume Srusce: Bear, 1272 


\subsection{EFFECTS OF TEMPERATURE ON FRACTURE FLOW SYSTEMS}

During the initial stages of repository construction and loading, ground water movement can adequately be defined by the approach outlined in previous sections. However, as the repository becomes heated in later stages of its life, the rate and direction of ground water flow may be altered. Large scale permeability tests at the Stripa Mine Project (Lundstrom and Stille, 1978) confirmed that permeability of the rock mass was reduced $50 \%$ as temperature was increased from $10^{\circ} \mathrm{C}$ to $35^{\circ} \mathrm{C}$. This decline in permeability can probably be attributed principally to a decrease in aperture along fractures resulting from thermal expansion of the rock mass.

Thermal convection may also alter ground water movements in a crystalline rock mass. In model studies condncted for the office of Nuclear Waste Isolation (1978), large convection cells were predicted to develop in the country rock surrounding a repository. However, Apps et al (1978) suggest that in fractured rocks of very small aperture, the Rayleigh number is so large that a local heat source is unlikely to cause natural circulatory convection. To establish throughflow due to a buoyancy unbalance requires recharge from a surrounding rock mass that is filled with cold ground water. If the repository is sited in nearly impermeable rock, then the low velocities of the regional system will restrict cold water inflow and control overall fluid movement. 
It should be noted that few, if any, large scale field studies have been undertaken to evaluate the effects of thermal convection in a granite rock mass. Most information now available is purely theoretical or is drawn from modeling studies which incorporate assumed hydraulic and thermal parameters. 


\subsection{REFERENCES}

Apps, J.A., N.G.W. Cook, and P.A. Witherspoon, 1978, Lawrence Berkeley Laboratory, GAIN, "Ar Appraisal of Underground Radioactive Waste Disposal in Argillaceous and Crystalline Rocks: Some Geochemical, Geomechanical, and Hydrogeological questions".

Apps, J., T. Doe, B. Doty, S. Doty, R. Galbraith, A. Kearns, .' B. Kohrt, J. Long, A. Monroe, T.N. Narasimhan, P. Nelson, C.R. Wilson, and P.A. Witherspoon, 1979, "Geohydrological Studies for Nuclear Waste Isolation at the Hanford Reservation, Volume II: Final Report, July, 1979.

Bear, J. 1972, Dynamics of Fluids in Porous Media, Americal Elsevier, New York, pp. 764 .

Bear, J. and Todd, P.K., 1960, The Transition Zone Between Fresh and Salt Waters in Coastal Aquifers, University of California, Water Resources Center Contribution, No. 29.

Beissel, D.R., 1971, Geophysical studies in fractured rock. M.S. Theisis, Colorado State University, Ft. Collins, Colorado.

Biachi, L. and D.T. Snow, 1969. Permeability of crystalline rock interpreted from measured orientations and aperatures of fractures: Annals of Arid Zone, 8:221-245.

Brace, W.F., 1979, Permeability of Crystalline and Argillacems B.ocks., Preprint Subiitted to Mt. Journal of Rock Mech. and Min. Sci.

Bredehoeft, J.D. and G.F. Pinder, 1973, Mass Transport in Flowing Ground water, Water Resources Research, 9, 1.

Crosby, w.0., 1881, on the absence of joint-structure at great depths, and its relations to the forms of coarsely crystalline eruptive masses. Geol. Mag. (Decade 2). 8.

Davis, S.N., 1969, "Porosity, Permeability of Natural Materials", Chapter 2 of Flow Through Porous Media, Edited by R.J.M. DeWiest. New York: Academic Press, Pp. 54-83.

Davis, S.N., and I.J. Turk, 1964, Optimum depth of wells in crystalline rocks. Ground Water. V. 2, No. 2, pp. 6-11.

Davis, S.N., and R.J.M. DeWiest, 1966, Hydrogeology, New York: $J$. Wiley and Sons, Inc. 
DeWlest, R.J.M., 1970, Geohydrology, New York: J. Wiley and Sons, P. 366.

Duguld, J.0., and P.C. Lee, 1971, "Flow in Fractured Porous Med1a", Water Rcsources Research.

Elnstein, H.H., and R.C. Hirschfeld, 1973, Model studies on mechanics of jointed rock, J. Soll Mech. Found Div. Amer. Soc. Div11 Eng., V. 99, pp. 229-248.

Freeze, R. A. and P.A. Witherspoon, "Theoretical analysis of regional groundwater flow. 2. Effect of water-table configuration and subsurface permeability variation", Water Resources Research, Vol. 3, No. 2, pp. 623-634, 1967.

Frit2, P., J.F. Barker, and J.E. Gale, "Geochemistry and Isotope Hydrology of Groundwaters in the Stripa Granite", April, 1979.

Gale, J., 1975. A numerical, field, and laboratory study of flow in rocks with deformable fractures: $\mathrm{Ph} . \mathrm{D}$. Thes is, University of California, Berkeley.

Gale, J.E., and P.A. Witherspoon, "An Approach to the Fracture Hydrology at Stripa": Preliminary Results, May, 1979.

Gringarten, A. and P.A. Witherspoon, 1972. A method of analyzing pump test data from fractured aquifers: Proc. Symp, on percolation through fissured rocks, International Society for Rock Mechanics, Stuttgart.

Grove, D.D., and W.A. Beetem, 1971, "Porosity and Dispersion Constant Calculations for a Fractured Carbonate Aqulfer Using the Two-Well Tracer Method", Water Resources Research, V. 7, No. 1 .

Hurr, R.T., and D.B. Richards, 1974, "Hydrologic Investigations" in Robinson, C.S. et al "Engineering Geologic, Geophysical, Hydrologic and Rock Mechanics Investigations of the Straight Creek Tunnel S1t: and P1lot Bore, Colorado", U.S. Geo1. Surv. Prof. Pe.per 815, pp. 79-88.

Iwai, K., 1976. Fundamental studies of fluid flow through a single fracture: PhD. Thesis, University of California, Berkeley.

Johnson Division, Universal o 1 Products, 1972, Ground Water and WeIls, st. Paul, Minn.

Jouanna, P., 1972, Seepage tests under stress in s1tu, Proceedings of the Percolation Through F1ssured Rock, Pap. T2-G, International Soclety of Rock Mechanics, Stuttgart, Germany.

Kendorsk1, Francis S., and M. Ashraf Mahtab, 1976, "Fracture Patterns and Anistrophy of San Manuel Quartz Monzonite", Assoc Eng. Geo. Bull. V. XIII, No. 1. 
Kendorsk1, F.S. and Mahtab, M. (1976) Fracture patterns and anisotropy of San Manuel quartz monzonite. Assoc. Eng. Geologists 13 .

Kranz, R.L., A.D. Frankel, T. Engelder, C. H, Scholz,"The Permeability of Whole and Jointed Barre Granite, "Pergamon Press Ltd., 1979, Printed in Great Britain.

Lachenbruch, A.H., 1961, Depth and spacing of tension cracks. Jour. Geophys. Research, 66.

Lew1s, D.C. and R.H. Burgh, 1964, Hydraulic character1stics of fractured and jolnted rock. Ground Water, Vol. 2, No. 3, pp. 4-9

Lohman, S.W., 1972, "Ground-water Hydraullcs", USGS Prof Paper 708, Gov. Printing office.

Louis, C. and M. Permot, 1972. Three dimensional investigation of flow conditions of Grand Maison damsite: Symp. on Percolation through fissured rocks, International Society for Rock Mechanics, Stuttgart.

Louis, C. and T. Maini, 1970. Determination of in situ hydraulic parameters in jointed rock: Congress International Society for Rock Mechanics, Belgrade, Vol. 1.

Lundstrom L. and Stille H, 1978, Large scale permeability :test of the granite in the stripa mine and thermal conductivity test, Lawrence Berkley Laboratory, Berkley,
California.

Maini, T. and G. Hocking, 1978. An examination of the feasibility of hydrologic isolation of a high level waste repository in crystalline rock: International Journal of Rock Mechanics and Mineral Engineering, in press.

Ma1n1, Y.N.T., 1971, In s1tu hydraul1c parameters 1n jointed rock: Their measurement and interpretation, Ph.D thesis, Imperial College, London.

Marine, I.W., 1965, Correlation and water-transm1tting properties of fractures. AIME, Soc. Petrol. Engrs. Preprint paper no. SPE $1280,7 \mathrm{pp}$.

MeWhorter, David B, and Daniel K. Sunada, I977, Ground-water Hydrology and Hydraulics, Fort Collins, Co. Water Resources Pub.

Office of Nuclear Waste Isolation (ONAI), 1978, Technical Support For GEIS: Radioactive Waste Isolation In Geologic Formation, Vol. 5, Baseline Rock Properties

Granite, Y/ONWT/TM-36/5,
1978, Vol. 21, Ground Water Movement and Nuclide Transport, Y/ONWI/TM-35/21.

1979, Geotechnical Assessment and Instrumencation Needs for Nuclear Waste Isolation in Crystalline and Angtllaceous Rocks, Symposium Proceedings, July $16-20,1978$ 
Pinder, G.F., 197j, A Gelerkin Finite-Element Simulation of Ground Water Contamination on Long Island, New York, Water Resources Research, 9, 6 .

Pratt, H.R., and H.S. Swolf's, W.F. Brace, A.D. Black, and J.W. Hand1n, 1977; Elast1c::and transport properfiés of 1ris1tu jointed granite, Int. J. Rock Mech. Mining Sc1., 14, 35-45,

-1971, Insitu and Laboratory Measurements of Velocity and Permeability.

Price, N, Fault and Joint Development in Brittle Rock, Pergamon, 1966.

Priest and Hudson, Discontinuity Spacings in Rock, Int. Journ. of Rock Mechanics and Min. Sci, V. 13, Pg. 135 (1976).

Proctor, J.F., and I.W. Marine, 1965, Geologic, hydrologic, and safety considerations on the storage of radioactive wastes in a vault excavated in crystalline rock. Nuclear sclence and Engineerin. vol. 22, pp. 350-365.

Rasmussen, W.F., 1963, permeability and Storage of Heterczeneous Aquifiers in the U.S., International Assoclation of Sc1. Hydrology, Publication 674, pp. 317-325.

Raven, 3., and Gale, J. (1976) Evaluation of structural and groundwater conditions in underground mines and excavations in Subsurface containment of solid radioactive wastes. Progress report EMR/GSC-RW Int. Rept. No. 1;76. Library Geological Survey of Canada, Ottawa, Canada.

Robinson, Cherles S, 1978, Hydrology of Fractured Crystalline Rocks, Henderson Mine; Colorado, Soc. of Min. Eng. T.P.

Scheidegger, A.E., 1961, General Theory of Dispersion in Porous Media. Journal of Geophys1cal Research, Vol. 66 , No. 10

Sharp, J. C., 1970. Fluid Elow through fissured media: Ph.D. dissertation, Imperial College, London.

Snow, David, T. 1965, A parallel plate model of permeable fractured media. Unpubl. PhD Thesis, Univ. of California, Berkely, 331 pp.

- 1968a, Rock fracture spacings, openings, and porosities. ASCE, Soll Mechan1cs and Foundations D1v. Jour. v. 94, no. 5MI, proc. paper 5736, pp. 73-91.

-1968b, Hydraulic characteristies of fractured metamorphic rocks of the Front Range and implications to the Rocky Mountain arsenal well. Colo. Sch. Mines Quarterly, v.63, no. 1, pp. 167-199.

-1968c, Fracture deformation and changes of permeab1lity and storage upon changes of fluld pressure. Colo. Sch. Mines Qdarterly, v. 63, no. 1. pp. 201-244. 
-1968d, Rock Fracture Spacings, Openings and Porosities, Journal Soll, Mec. Foundation D1v., Proc. ASCE, 94, ;3-91. 1969, An1sotrop1c permeability of fractured media. Water Resources Res. v.5, no. 6, pp. 1273-1289.

-1970, The frequency and apertures of fractures in rock. Jour. Rod. Mech. Min. Sc1. v.7, pp. 23-40.

-1371, Fracture Deformation and Changes in Permeability and Storage Upon Changes of Fluld Pressure, Colorado School of Mines Quarterly.

Stewart, J.W. 1962b. Relation of permeability and "olnting in crystalline metamorphic rocks near Jonesboro, Geogia. (Article 69 in Geological Survey Research, 196?) U.S. Geol. Survey Prof. Paper 450D, pp. D168-D170. $-1962 a$, Water ylelding potential of weathered crystaline rocks at the Georgla Nuclear Laboratory. (Art1cle 43 in Geological Survey Research, 1962). U.S. Geol. Survey Prof. Paper 450B, pp. B106-B107.

-1964, Infiltration and permeability of weathered crystalline rocks, Georgia Nuclear Laboratory, Dawson County, Georgla, U.S. Geol. Survey Bull. 1133-D, 59pp.

Streltsova, I.D., 1976, Hydrodynamics of Groundwater Flow in a Fractured Formation, Water Resolrces Research, Vol. 12, No. $3, \mathrm{pp} .405-414$.

Swolfs, H. H.R. Pratt, A.D. Black. W.F. Brace, A.S. Oranpe and K.A. Grenseth, 1975, In s1tu propertoes of a jolnted granite (Abs) Trans. Am. Geophys. Union, 55, 432.

Taylor, G.I., 1953, Dispersion of soluble matter in solvent flowing slowly through a tube, Proc. Roy, Soc. A, No. 1137 , $219,186-203$.

Todd, D.K., 1959, 1967; Groundwater Hydrology, John Wiley \& Sons, Inc.

Towndrow, R.G.P., Information Office, Atomic Energy Research Est., Harweil, Symposium Proceedings, July 16-20, 1978., GAIN, "Geotechnical Assessment and Instrumentation Needs for Wuclear Waste Isolation in Crystalline and Argillaceous Rocks, "Prepared for the U.S. Dept. of Energy under Contract No. W-7405-ENG-48.

Uhl, Vincent W. Jr. and G.K. Sharma, 1978, Results of Pumping Tests in Crystalline-Rock Aquifers, Groundwater, V.16 No.3.

U.S.G.S., 1977, U.S. Geol. Survey Yearbook. Role of Earth Sciences in the Disposal of Radioactive Waste

Wahlstrom, E.E. and V.Q. Hornback, 1962, Geolngy fo the Harold D. Roberts Tunnel, Colorado: west portal to station $468 \& 49$. Geol. Soc. America Bull. 73 
Witherspoon, P.A., "Movement of Fluids in Largely Impermeable Rocks, "Report from seminars held January 27-29, 1977, University of Texas at Austin, Y/OWI/SUB-77/14223, Apri1, 1977.

Witherspoon, P.A., P. Nelson, T. Doe, R. Thorpe, B. Paulsson, J. Gale, C. Forster, "Rock Mass Characterization for Storage of Nuclear Waste in Granite, "Swedish-American Cooperative Program on Radioactive Waste Storage in Mined Caverns in Crystalline Rock, February, 1979. 
TABLE OF CONTENTS

\section{CHAPTER 1 - GRANITES}

1.0 PREFACE

PAGE NUIBER

$1-1$

GRANITES

1.1 INTRODUCTION TO CHARACTER OF GRANITIC ROCK $1-4$

1.2 CLASSIFICATION $1-5$

1.3 COMPOSITION $1-6$

1.4 STRUCTURE OF GRANITIC ROCK BODIES 1-10

1.5 GENESIS 1-11

1.6 WEATHERING OF GRANITIC ROCKS 1-12

1.7 DESCRIPTION OF OCCURRENCES 1-13

1.8 REFERENCES $1-36$

GEOMECHANICS OF GRANITES

1.9 INTRODUCTION TO GEOMECHANICS OF GRANITES $1-40$

1.10 IN SITU STRESSES 1-45

1.11 MECHANICAL PROPERTIES 1-52

1.12 THERMAL PROPERTIES 1-64

1.13 THERMOELASTIC PROPERTIES 1-82

1.14 OTHER CONSIDERATIONS 1-100

1.15 SCALING OF LABORATORY RESULTS 1-108

1.16 REFERENCES $1-123$

HYDROLOGY OE-GRAPITES

1.17 INTRODUCTION TO HYDROLOGY OF GRANITES 1-129

1.18 FUNDAMENTALS OF GROUND WATER FLOW 1-130

1.19 GROUND WATER FLOW THROUGH SINGLE FRACTURES 1-135

1.20 FRACTURE NETWORKS $1-139$ 
TABLE 1-20 TO FOLLOW UNDER SEPARATE COVER 
TABLE OF CONTENTS

CHAPTER 1 (CONT)

1.21 REGIONAL GROUND WATER FLOW

PAGE NUMBER

1.22 EFIECTS OF TEMPERATURE ON FRACTURE FLOW SYSTEMS

1-152

1.23 REFERENCES

1-158

$1-160$ 


\section{LIST OF FIGURES}

CHAPTER 1 - GRANITES

PAGE NIMBER

1-1 Mineral composition of granitic rocks

1-? Granitic occurences chosen for inclusion 1-14 in study

1-3 Engineering classification of intact rock based on uniaxial compressive strength and modulus ratio

1-4 Compilation of measurements of the virgin state of stress in the rock

1-5 Increase of average horizontal stress with depth in precambrian rocks

1-6 Variation of principal stresses in the borehole

1-7 Direction of the principal stresses at each measure point plotted

1-8 Axial stress versus strain plots for confining pressures of $0,10,20$ abd $30 \mathrm{MPa}$

I-9 Graph showing variation of Young's modulus and fracture stress $\sigma_{c}$ with confining pressure

1-10 Variation of thermal conductivity wi th temperature

1-11 Variation of thermal conductivity and diffusivity with temperature

1-12 Variation of thermal conductivity with temperature

1-13 Thermal conductivity of selected igneous rocks

1-14 Variation of specific heat witl. temperature

1-15 Variation of normalized thermal diffusivity with temperature

1-16 Variation of thermal diffusivity with temperature rocks as a funetion of temperature 
Chapter 1 - continued

PAGE NUMBER

1-18 Typical stress versus strain plot from uniaxial test at $150^{\circ} \mathrm{c}$

1-19 Variation of ultimate compressive stress with temperature

1-20 Strength of rocks and minerals at $5 \mathrm{~kb}$.

1-21 Effect of temperature on stressstrain curves for rocks

1-22 Young's modulus versus temperature showing $90 \%$ confidence limits

1-23Poisson ratio versus temperature showing $90 \%$ confidence limits

1-24 Variation of Young's modulus, shear modulus, and Poisson's ratio with temperature

1-25 Variation of Iinear thermal expansion with temperature

1-26 Variation of coefficient of linear thermal expansion with temperature

1-27 Volume thermal expansion of some common minerals

1-28 Average linear expansion of rocks of excellent and very good pierceability

1-29 Average linear expansion of rocks of grod and fair pierceability Westerly granite

1-31 Typical creep curve of watersaturated Westerly granite

1-32 A diagrem illustrating the effect of size on the uniaxial compressive strength of qual $z$ diorite

1-33 In situ Young's modulus determinations $*+\cdots+1-113$ versus fracture density from visual inspection of core 


\section{LIST OF FIGURES}

Chapter 1 - continued

PAGE NUMBER

1-34 Histograms of CSM-cell determinations of Young's modulus

1-35 Curves showing the predicted and measured temperatures as a function of time at a radius of 0.87 in from the mid-points of the two innermost heaters on the $y$-axis

1-36 Predicted isotherms and measured temperatures in a horizontal plane through the middle of the t:me-scale experiment 90 days after heating had started

1-37 Predicted isotherms and measured temperatures in a vertical plane $(y=3.5 \mathrm{~m})$ con taining three of the time-scale heaters, 90 days after heating had started

1-38 Predicted isotherms and measured temperatures in a horizontal plane through the middle of the $5 \mathrm{kw}$ full-scale heater, 65 days after heating had started

1.39 Predicted and measured relative displacements between anchor points 3 m below the heater midplane and the hole collars in the floor of the time-scale drift, plotted as a function of time

1-40 Predicted and measured horizontal displacements of the rock in the mid-plane of the $5 \mathrm{kw}$ full-scale heater taken along different directions

1-41 Predicted and measured horizontal displacements below the $5 \mathrm{kw}$ full-scale heater at anchor points symetrically positioned on each side of the heater

1-42 Fracture openings in the geneisses of the Front Range, Colorado, computed from injection tests

1-43 The mean permeability in each dept cone at 4 damsites v.s. the mean depth. I midpoints of test sections

1-44 Apparent spacing of individuals of each of three assumed orthogonal sets of water-bearing fractures at four damsites in geneisses of the Front Range, Colorado, computed from injection tests 


\section{LIST OF FIGURES}

Chapter 1 - Continued

PAGE NUMBER

1-45 Summary of laboratory and in situ

$1-148$ measurements of permeability in

$1-149$

1-46 Effect of water-table configuration on regional ground water flow through homogeneous isotropic media

1-47 Definition of a representative elementary volume $1-157$ 
PAGE NTMBER

1-1 Chemical analyses and mineral norms for

average compositions for granite, quartz monzonite and granodiorite

1-2 Consequence of temperature dependence of rock properties on cavern stability

1-3 Stress in Ontario rocks

1-4 Properties of intact granite

1-5 Intact properties of Barre granite

1-6 Intact properties of Colville granite unaltered

1-7 Intact properties of Colville granite (slightly altered)

1-8 Intact properties of Pikes Peak granite

1-9 Intact properties of St. Cloud Gray Granodiorite (Precambrian Granite)

1-10 Compaxison of rock properties

1-11 Conductivity of rocks

1-12 Classification, composition, texture, structure piercing rating, linear thermal expansion, specific heat, and density of 19 Canadian rock minerals

1-13 Specific heat determinations of various samples

1-14 Fusion temperatures of series "A" rocks $1-80$

1-15 Fusion temperatures of series "B" rocks 1-81

1-16 Measured coefficients of thermal expansion 1-93

1-17 Mineralogical composition of rocks vs rock- 1-95 renoval rate and percent elongation at $600^{\circ} \mathrm{C}$

1-18 Compression tests on granite

1-19 smal1-scale anisotropy test results 1-101

1-20 Sumary oi rock mechanics properties 1-102

1-21 Values of the exponent $n$ in the equation 2-206 $\xi=A D$ in the creep of granites and a granodiorite at room temperature 
TABLE OF CONTENTS

Chapter 2

Page No.

2.1 Introduction to Geologic Character of Basalt 2-2

$2.2 \quad$ Classification 2-3

2.3 Eomposition 2-6

2.4 Primary Structure of Basaltic Bodies 2-8

2.5 Genesis 2-9

2.6 Weathering of Basalt 2-II

$\begin{array}{lll}2.7 & \text { Description of Occurrences } & 2-12\end{array}$

Columbia River Basal.t

Snake River Plain Basalt

The Yodoc Plateau

$\begin{array}{llr}2.8 & \text { References } & 2-19\end{array}$

2.9 Introduction to Geomechanics of Basalt 2-22

$\begin{array}{lll}2.10 & \text { Stress State } & 2-32\end{array}$

In Situ Stress

Stresses Induced by Excavation

Thermally Induced Stresses

2.11 Mechanical Properties of Intact Rock 2-,

2.12 Thermal Properties 2-80

2.13 Thermoelastic Properties 2-92

2.14 Other Considerations 2-106

2.15 Scaling of Laboratory Results ? Ing

2.16 References -122

2.17 Introduction to Hydrology of Basalt $2-.27$

2.18 Physical Characteristics of Basalt Flows -128

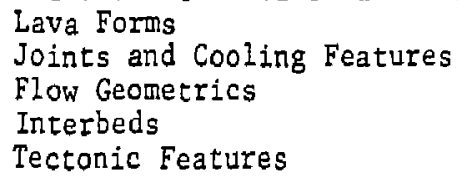

2.19 Porosity, Permeability and Ground Water Flow Regimes 2-136 
Page No.

2.20 Hydrologic Features of the Columbia River Basalt 2-140 Origin

Stratigraphy of the Pasco Basin

Hydrology of the Pasco Basin Sequence

General Characteristics of Ground Water Flow

Porosity

Hydraulic Conductivity

Vertical Permeability

Vertical Hydraulic Gradients

Storage Coefficients

Average Velocity of Ground Water

Regional Ground Water Systems

2.21 Hydrology of the Snake River Plain

Orj.gin

$2-168$

Stratigraphy

Characteristics of Ground Water Flow

Hydraulic Conductivity

Storage Coefficients

Average Velocity of Ground Water

Regional Ground Water Systems

2.22 Hydrology of the Modoc Plateau

Origin

Hydrology of Basalt Flows

2.23 References

Appendices

Appendix A Sumary Tables of Rock Properties

A-I Sumary Table of Strength Properties Granitic and Metamorphic Rocks

A-II Summary Table of Strength Properties Basalts

A-III Sumary Table of tydraulic and Thermal Proporties - Granitic and Metamorphic Rocks

A-IV Summary lable of Hydraulic and Thernal Properties - Basalts

$A=V$ Explanation of Notation

$A-V I$ Sources for Appendix A

Appendix B Glossary

B- 2 


\section{LIST OF TABLES}

TABLE

TITLE

PAGE NO.

2-1 Chemical composition and mineralogy in percent of some basaltic rocks ............ 2-7

2-2 Geomechanical factors to be considered ........ 2-24

2-3 Canister receipt criteria recommendations ...... 2-29

2-4 Local areal thermal loading - basalt ........ 2-30

2-5 Basalt properties .................. 2-43

2-6 Comparison of boundary stresses at selected 2-52 points for various configurations and loadings....

2-7 Intact properties of Dresser basalt ........ 2-56

2-8 Intact properties of Amchitka Island dense basalt ........................ 2-57

2-9 Intact properties of Nevada test site basalt ... 2-58

2-10 Intact properties of Columbia River Croup basalt ....................... 2-59

2-11 Dresser basalt test results $\ldots \ldots \ldots \ldots \ldots \ldots \ldots 2-60$

2-12 Properties of Dresser basalt ............ 2-61

2-13 Average engineering properties of Amchitka basalt (air dried) $\ldots \ldots \ldots \ldots \ldots \ldots \ldots \ldots \ldots \ldots . \ldots 2$

2-14 Average engineering properties of Amchitka basalt (waier saturated) ................. 2-64

2-15 Summary of triaxial comparison strength tests on core from the Hanford Reservation ...... 2-71

2-16 Summary of rock properties. Bacon Siphon and Tunnel = second unit - DH-100 series samples .... 2-72

2-17 Summary of rock properties. Bacon Siphon and Tunnel - second unit - DH-200 series samples .... 2-73

2-18 Strength data on basalts ............... 2-77

2-19 Elastic properties of basalcic rock ......... 2-78

2-20 Density of some basalts $\ldots \ldots \ldots \ldots \ldots \ldots \ldots \ldots .2-82$ 
LIST OF TABLES (CONTINUED)

TABLE

TITLE

PAGE NO.

2-21 Thermal properties of basalt as a

function of temperature ................. 2-83

2-22 Heat capacity $\ldots \ldots \ldots \ldots \ldots \ldots \ldots \ldots \ldots \ldots \ldots \ldots . \ldots \ldots 4$

2-23 Thermal conductivity of basaltic rocks ....... 2-86

2-24 Thermal diffusivity $\ldots \ldots \ldots \ldots \ldots \ldots \ldots \ldots \ldots \ldots .8 \ldots \ldots$

2-25 Summary of average physical properties

for basalt ........................ 2-91

2-26 Example of influence of temperature and pressure on the elastic properties of some basaltic rocks

2-27 Experimental values of Young's Modulus and

Poisson's ratio at elevated temperatures

in Dresser basalt ....................... 2-94

2-28 Elastic moduli data for Dresser basalt ........ 2-75

2-2.9 Properties of Dresser basalt .............2-96

2-30 Coefficient of linear thermal expansion $\ldots \ldots \ldots .2=99$

2-31 Sumary of thermomechanical basalt properties ... 2-105

2-32 Creep and failure characteristics of Amchitka Island rocks under uniaxial

and compressive stress ................ 2-107

2-33 Partial description of typical

structures in basalt .................. 2-111

2-34 Intact properties for a typical dense basalt . . . 2-115

2-35 Principal zones of high hydraulic

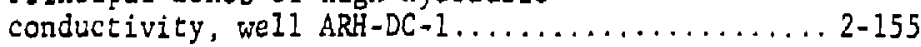

2-36 Hydratic characteristics of the

uppermost confined aquifers $\ldots \ldots \ldots \ldots \ldots \ldots \ldots, 2-156$

2-37 Range of hydrologic properites of lower

Yakima basalt flows and interbeds.

2-38 Summary of laboratory analyses of

rock cores from test well ARH-DC-1 ......... 2-159

2-39 Storage coefficients computed from hydraulic

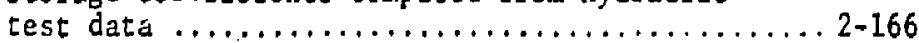




\section{LIST OF TABLES (CONTINUED)}

TABLE TITLE

PAGE NO.

2-40 Vertical hydraulic conductivities of sedimentary interbeds $\ldots \ldots \ldots \ldots \ldots \ldots \ldots \ldots \ldots, 2-178$ 


\section{LIST OF FIGURES}

FIGURE

TITLE

PAGE NO.

2-1 Mineralogica: subgroups of basalts .......... 2-4

2-2 Flood basalt occurrences chcsen for study ....., 2-13

2-3 Extraction ratio chart .................. 2-28

2-4 Vertical stress with depth $\ldots \ldots \ldots \ldots \ldots \ldots \ldots . . \ldots 2-35$

2-5 Ratio of the average horizontal stress

2-6 Plot of vertical stresses against

depth below surface $\ldots \ldots \ldots \ldots \ldots \ldots \ldots \ldots \ldots \ldots . \ldots \ldots$ 2-37

2-7 Variation of ratio of average horizontal

stress to vertical stress with depth

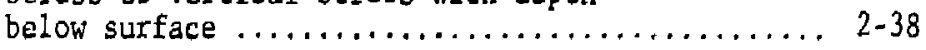

2-8 Base case for excavation and canister

location geometry $\ldots \ldots \ldots \ldots \ldots \ldots \ldots \ldots \ldots \ldots . \ldots 2-41$

2-9 Effect of areal thermal loading on

boundary stresses for the base case $\ldots \ldots \ldots \ldots .2-42$

2-10 Effeci of insitu field stress ratio

on boundary stresses for base case .......... 2-44

2-11 Temperature contours for elapsed time

of 5 years - areal thermal loading of $25 \mathrm{~W} / \mathrm{m} 2 \ldots \ldots, 2-47$

2-12 Stresses for elapsed titne of 5 years areal thermal loading of $25 \mathrm{w} / \mathrm{m} 2 \ldots \ldots \ldots \ldots, 2-48$

2-13 Boundary stresses and temperatures

for central excavation at an elapsed

time of 5 years $-25 \mathrm{~W} / \mathrm{m} 2$ at $1000 \mathrm{~m}$ depth ...... 2-50

2-14 Effect of basalt thermomechanical properties on stresses for the base case $\ldots \ldots \ldots, 2-51$

2-15 Engineering classification for intact rocksummary plot igneous rocks, 176 specimens .......2-55

2-16 Wet vs dry tensile strengths of local rock $\ldots \ldots \ldots 2.66$

2-17 Mohr circles for dense and vesicular basalt ..... 2-68 


\section{LIST OF FIGURES (CONTINUED)}

FIGURE

FIGURE

PAGE NO.

2-18 Relationship between strength and confining pressure for basaltic rocks of different porosity

2-19 Variation of initial tangent Poisson's ratio with confining pressure

2-20 Compressive strength versus porosity

Columbia Plateau basalt

2-21 Compressive strength versus density

Columbia Plateau basalt

2-22 Relation of compressive strengths

and specific gravity.

2-23 Subsurface temperature as a function of depth in DC-1 drill hole (geothermal gradient) ....... 2-81

2-24 Inverse the mal conductivity versus temperature, Dresser basalt ............... 2-88

2-25 Comparison of the specific heats for the $\mathrm{six}$ rock types

2-26 Cavern temperature versus cavern radius for various thermal conductivity values .......... 2-90

2-27 Elastic moduli and Poisson's ratio as a function of temperature for Dresser basalt ...... 2-97

2-28 Influence of temperature and strain rate on strength of Dresser basalt ........... 2-98

2-29 Form of thermal conductivity volumetric strain relationship ............. 2-102

2-30 Conductivity versus radial distauce

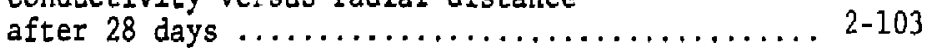

2-31 Comparison of temperatures for uniform conductivity (Case $A$ ) and basalt decrepitation (Case B)

2-32 Creep curves for basalt ................ 2-108

2-33 Non-1inear curve of strength for rock mass ..... 2-113 


\section{LIST OF FIGURES (CONTINUED)}

EIGURE

TITLE

PAGE NO.

2-34 Influence of normal stre,s on normal

stiffness $\left(\mathbb{K}_{\mathrm{y}}\right)$ of a joint $\ldots \ldots \ldots \ldots \ldots \ldots \ldots \ldots . \ldots \ldots$

2-35 Thermal conductivity of porous material ... . . . 2-117

2-36 Typical shear stress, shear deformation

response of joints ................... 2-118

2-37 Minimim coefficients of friction versus

normal pressure for granite basalt .......... 2-120

2-38 Initial residual coefficients of friction

versus normal pressure for lower granite

basalt

2-39 Formation of "ideal" hexagonal fracture

pattern due to uniform contraction toward

evenly-spaced centers .................. 2-131

2-40 Simplified cross section of the

Pomona flow unit $\ldots \ldots \ldots \ldots \ldots \ldots \ldots \ldots \ldots \ldots . \ldots \ldots$ 2-132

2-41 Hydraulic conductivity data from basalts

in the Northwest United States ............. 2-138

$\therefore$-42 The Columbia River Plateau ............... 2-142

2-43 Stratigraphy of the Pasco Basin ........... 2-144

2-44 Geography of the Pasco Basin ............. 2-145

2-45 Generalized cross section $A-A^{\prime}$ parallel to the main axis of the Pasco Basin ............... 2-146

2-46 Generalized cross section B-B' normal

to axis of Pasco Basin ................... 2-147

2-47 Hydrostragigraphic characteristics of the Pasco Basin ........................ 2-150

2-48 Approximate undisturbed ground water head for isolated water-bearing zones in well ARH-DC-1 ... 2-152

2-49 Piezometers installed in ARH-DG-1 ......... 2-161

2-50 Generalized basalt stratigraphy

within the Pasco Basin .................. 2-163 


\section{LIST OF FIGURES (CONTINUED)}

FIGURE

TITLE

PAGE NO,

2-51 Summary of pressure data versus

stratigraphy $\ldots \ldots \ldots \ldots \ldots \ldots \ldots \ldots \ldots \ldots \ldots, 2-164$

2-52 Location map of Snake River Plain ............ 2-169

2-53 Cross sections showing hypothetical stages

of grabening during formation of the Snake

River Plain ............................... 2-172

2-54 Crose sections of INEL burial ground ........... 2-173

2-55 Regional ground water flow - Snake River Plain ... 2-182 
GEOLOGIC CHARACTER OF BASALT

2-1 
2.1 INTRODUCTION TO GEOLOGIC CHARACTER OF BASALT

Basalt is a dark-colored, mafic igneous rock composed of calcium plagioclase and clinopyroxene. It is generally extrusive or volcanic in origin causing a glassy or finegrained texture. Basalt is one of the major rock types exposed at the ea.th's surface. The ocean basins are composed of it and extensive basaltic terranes occur on all continents.

In recent years, as more sophisticated physical-chenical data have been gathered, the basalts, their tectonic frameworks, and their compositions, have become a major source of support and argument for plate sectonic and other planetarr development theory. As such, basalt has commanded an intorest far beyond its already major importance as a common terrane at the earth's surface. 


\subsection{CLASSIFICATION}

All igneous rocks, including basalts, are classified on the basis of texture and mineralogy. By definition basalts are all fine-grained, calcium plagioclase-clinopyroxene rocks. Within this framework there are numbers of textures and mineral subclasses that specify different genetic types of basalt.

There are two main mineralogical subgroups of basalts (Figure 2-1). Each of these is derived from a distinct type of parent magna. The tholeitic magma is saturated with $5 i 02$ and produces basalts consisting of calcium-poor augite, ( $\mathrm{Ca}, \mathrm{Na})$ (Mg, Fe,Al, Ti) $(S i, A I)_{2} O_{6}$, labradorite plagioclase, (Ca, $\left.\mathrm{Na}\right) \mathrm{AI}(\mathrm{Si}, \mathrm{Al})$ $\mathrm{Si}_{2} \mathrm{O}_{8}$, anci iron oxides. Olivine, $\left(\mathrm{ag}_{\mathrm{g}}, \mathrm{Fe}\right) \mathrm{SiO}_{4}$, may be absent or, as in olivine tholeiite, present in accessory amounts.

The alkali basaltic magma is undersaturated with respect to $\mathrm{SiO}_{2}$ and produces nepheline, (MaK) $\mathrm{AlSiO}_{4}$, bearing calciumrich augite. In the resulting rocks, alkali feldspars often occur with the calcium plagioclases and, in general, alkali basalts contain much more complex assemblages of eldspars. As with the tholeiites, olivine may be absent or occur as an accessory; however, it is more common in the alkalis, Also, alkali-basaltic olivine occurs in the groundmass and $1 t$ tends to be zoned from magnesium-rich to iron-rich. This is unusual for tholeite olivine. 


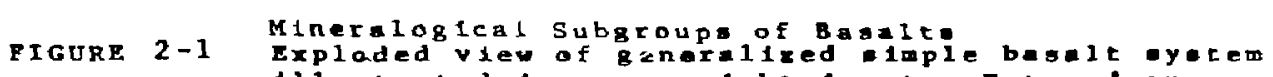

lilustrated in urper rishe incot. Entered are names

of rock whese major normetive phases are contalned

In the tetrahedra. Mame undmrilined are within the

tetrahedra. Nawes in face are writcen parallel to

Laso. Lherrolite te in ol-cpx-opx face. An additional

Inset, ol-Cpx-An, glved alternative nomenclature when

p1agloclase t. rich in An. After Yoder and Tilley (1962).

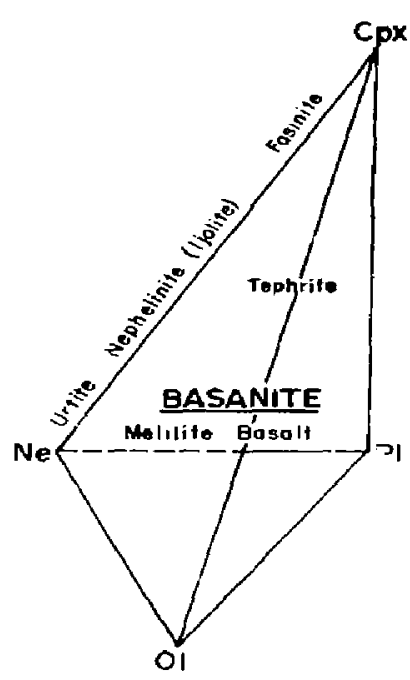

ALKALI BASALT GROUP

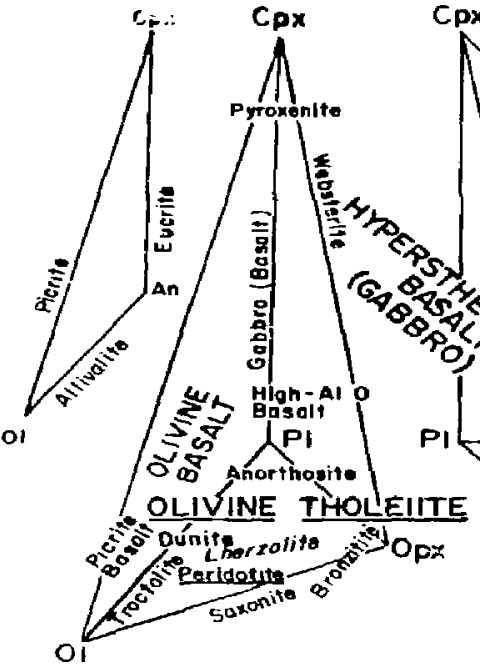

OLIVINE THOLEIITE GROUP
CLINOPYROXENE
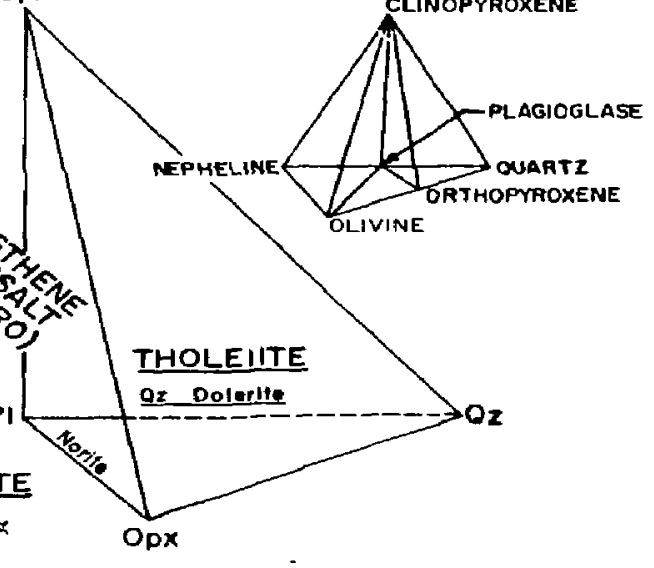
Two lesser suites of basalts are the calc-alkali series and the high alumina series. The genesis of both are controversial. The calc-alkalis are thought to be high alkali differentiates of the tholeiitic magmas. The high alumina basalts contain in excess of 17 percent $\mathrm{Al}_{2} \mathrm{O}_{3}$ and are also thought to be derivatives of the tholeiites.

Basaltic textures and their causes are almost as prolific as the various basalt rock names. For practical purposes, particularly if the physical properties of the rock are of concern, only a few are important. Basalts tend to be porphyritic (larger crystals set in a fine-grained groundmass). The large crystals or phenocrysts are often aligned, creating anisotropy. The ground-mass may be vitreous or glassy. Although basalt glasses, or obsidians, are rare, matrices can contain high proportions of glass. Basalt flows commonly contain frothy or vesicular layers where gasses Were trapped during extrusion. Also, flows usually have some type of jointing that occurred during cooling. This weakens the rock body and allows more rapid weathering. 


\subsection{COMPOSITION}

The major mineral groups that make basalts (plagioclases, pyroxenes and olivine) produce a dark-colored heavy rock that is relatively low in silica and high in iron, magnesium and cal-:um. The mineral and chemical analyses for examples of a tholeiite, an alkali and a bigh alumina basalt are given in Table 2-1. The rather exacting compositional requirements discussed under Classification are evident. The tholeiite is high in $\mathrm{SiO}_{2}$ and the alkali basalt is undersaturated in $\mathrm{SiO}_{2}$ and high in sodium and potassium. The high alumina basalt is high in $\mathrm{Al}_{2} \mathrm{O}_{3}$. 


$\begin{array}{ccc}\text { Olivine } & \text { Olivine } \\ \text { Tholeiite } & \text { Alkaligh }\end{array}$

\begin{tabular}{|c|c|c|c|}
\hline $\mathrm{SiO}_{2}$ & 49.18 & 48.27 & 41.60 \\
\hline $\mathrm{TiO}_{2}$ & 2.29 & 0.89 & 2.64 \\
\hline $\mathrm{AI}_{2} \mathrm{O}_{3}$ & 13.33 & $18.2 B$ & 10.38 \\
\hline $\mathrm{Fe}_{2} \mathrm{O}_{3}$ & 1.31 & 1.04 & 3.58 \\
\hline $\mathrm{FeO}$ & 9.71 & 8.31 & 9.07 \\
\hline Mino & 0.16 & 0.17 & 0.20 \\
\hline Mgo & 10.41 & 8.96 & 14.38 \\
\hline $\mathrm{CaO}$ & 10.93 & 11.32 & 10.90 \\
\hline $\mathrm{Na}_{2} \mathrm{O}$ & 2.15 & 2.80 & 4.32 \\
\hline $\mathrm{K}_{2} \mathrm{O}$ & 0.51 & 0.14 & 1.02 \\
\hline $\mathrm{H}_{2} \mathrm{O}$ & 0.09 & 0.22 & 1.46 \\
\hline $\mathrm{P}_{2} \mathrm{O}_{5}$ & 0.16 & 0.07 & 0.38 \\
\hline Quartz $\left(\mathrm{SiO}_{2}\right)$ & - & - & $=$ \\
\hline Orthoclase $\mathrm{KAlSi}_{3} \mathrm{O}_{8}$ & 2.78 & 0.56 & 0.56 \\
\hline Albite $\mathrm{NaAlSi}_{3} \mathrm{O}_{8}$ & 17.82 & 23.58 & - \\
\hline Anorthite $\mathrm{CaAI}_{2} \mathrm{Si}_{2} \mathrm{O}_{8}$ & 25.30 & 39.97 & 5.84 \\
\hline Diopside $\left(\mathrm{CaMgSi}_{2} \mathrm{O}_{6}\right)$ & 22.93 & 15.23 & 36.54 \\
\hline Hypersthene $(\mathrm{Mg}, \mathrm{Fe})_{2} \mathrm{Si}_{2} \mathrm{O}_{6}$ & 15.35 & - & - \\
\hline Olivine $(\mathrm{Mg}, \mathrm{Fe}) \mathrm{SiO}_{4}$ & 9.14 & 20.55 & 20.37 \\
\hline Magnetite $\mathrm{Fe}_{3} \mathrm{O}_{4}$ & 2.09 & 1.39 & 5.10 \\
\hline Ilmenite $\mathrm{FeTiO}_{3}$ & 4.41 & 1.67 & 5.02 \\
\hline \multicolumn{4}{|l|}{ Apatite } \\
\hline $\begin{array}{l}\mathrm{Ca}_{5}\left(\mathrm{PO}_{4}\right) 3^{(\mathrm{F}, \mathrm{OH}, \mathrm{Cl})} \\
\text { Nephel ine (Na, K)Alsio. }\end{array}$ & 0.34 & 0.16 & $\begin{array}{r}1.01 \\
19.88\end{array}$ \\
\hline $\begin{array}{l}\text { Nepheline }(\mathrm{Na}, \mathrm{K}) \mathrm{AlSiO} \\
\left.\text { Leucite (KAlsi, }{ }_{4}\right)\end{array}$ & - & 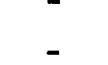 & 19.88 \\
\hline 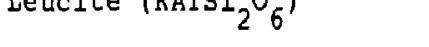 & & & 4.50 \\
\hline
\end{tabular}

Table 2-1 Chemical Composition and Mineralogy in percent of some basaltic rocks (1. Kilawea Caldera, Hawaii; 2. Medicine Lake Highlands, California; 3. Ponape Island) Source: Hess and Poldervaart, 1967 


\subsection{PRIMARY STRUCTURE OF BASALTIC BODIES}

Most basalts occur in flows. Small near-surface intrusions have produced basalt but the volume is very minor. The majority of the great flow sequences underlie the oceans. These have spread from centers along the earth's surface plate boundaries and represent the formation of the new crust required to fill in as the plates shift.

There are also major periods of basalt flow deposition on the continents. These flow sequences, known as flood or plateau basalts, spread to great thicknesses over various areas of alI the continents during the Permian, Triassic and mid-Tertiary periods. Because of their accessibility these continental flood basalts have, until recently, received more attention than the oceanic basalts. For the purposes of this report, they certainly are the most important type of occurrence. 


\subsection{GENESIS}

Genetic theory for the basaltic rocks is extremely detailed and complicated. Basaltic magmas are now conceded to develop directly from the earth's mantle material (Carmichael et al, 1974; Hess and Poldervaart, 1967). Controversies are still heated, however, over where in the mantle this occurs, what materials are involved, and how many primary basaltic magmas are developed.

The major type of basalt in both oceanic and continental occurrences is tholeitic. The magma producing this basalt is thought to be a primary magma generated from a garnetperidotite, or eclogite, in the upper mantle. Continental and oceanic sholeiites are slightly different in some respects, particularly in their trace element suites. However, these differences are believed to be due to contamination as the magmas pass up through either the continental or oceanic crusts (Carmichael et al, 1974; Hess and Poldervaart, 1967).

Alkali, calc-alkali, and high alumina basaltic magmas hypothetically all develop from tholeiite magma. For calcalkali and high alumina magmas, the hypothesis is subjective simply because the data are insufficient and inconclusive. For alkali basaltic magma, the problem is more substantial. 
AlkaIi magma can be differentiated from tholeitic but an enormous volume of tholeitic magma is required. Proponents of the relationship have devised a partial melting of tholeiites with subsequent filter pressing of alkali magma to solve this problem. Opponents believe this is fortuitous. They prefer a separate primary alkalic magma (Hess and Poldervaart, 1967). This would mean that the concept of a relatively homogenous mantle is suspect. Hence, the problem of the alkali basaltic magma source still awaits solution. 


\subsection{WEATHERING OF BATALT}

Basalts are composed of high temperature, igneous rock minerals. These are as much out-of-equilibrium with the surface environment as any group of rock-forming minerals can be, Hence, basalt will rapidly deteriorate once it is exposed. Physically, it is compact and resistant. However, most bodies are severely fractured during post-depositional cooling. This accelerates chemical and physical deterioration. 


\subsection{DESCRIPTION OF OCCURRENCES}

Extensive areas of flood basalts occur in the northwestern United States. This region, known as the Columbia Plateau, is the largest area of basalt in the United States. All of the flows of this region are of the continental tholeiitic type.

The Columbia plateau flood basalt region consists of three distinct, smaller areas of basalt flows (Figure 2-2). The Columbia River Basalt covers a large area in central and southern Washington. The Modoc Plateau is a smaller area mainly in northern California. The Snake River Plain extends across most of southern Idaho. Each area has basalts of slightly different stratigraphic and water-bearing propities.

The following discussions of these three areas will concentrate on general feztures that are consistent with the entire area. When dealing with such lares areas, it is not possible to provide certain types of geologic daca that may only be important for given locales. Small-scale fracturing or jointing is an example. Trends, intensities, and depths of occurrence for such features can orly be neasured, and their importance to rock properties judged, for a specific site. 


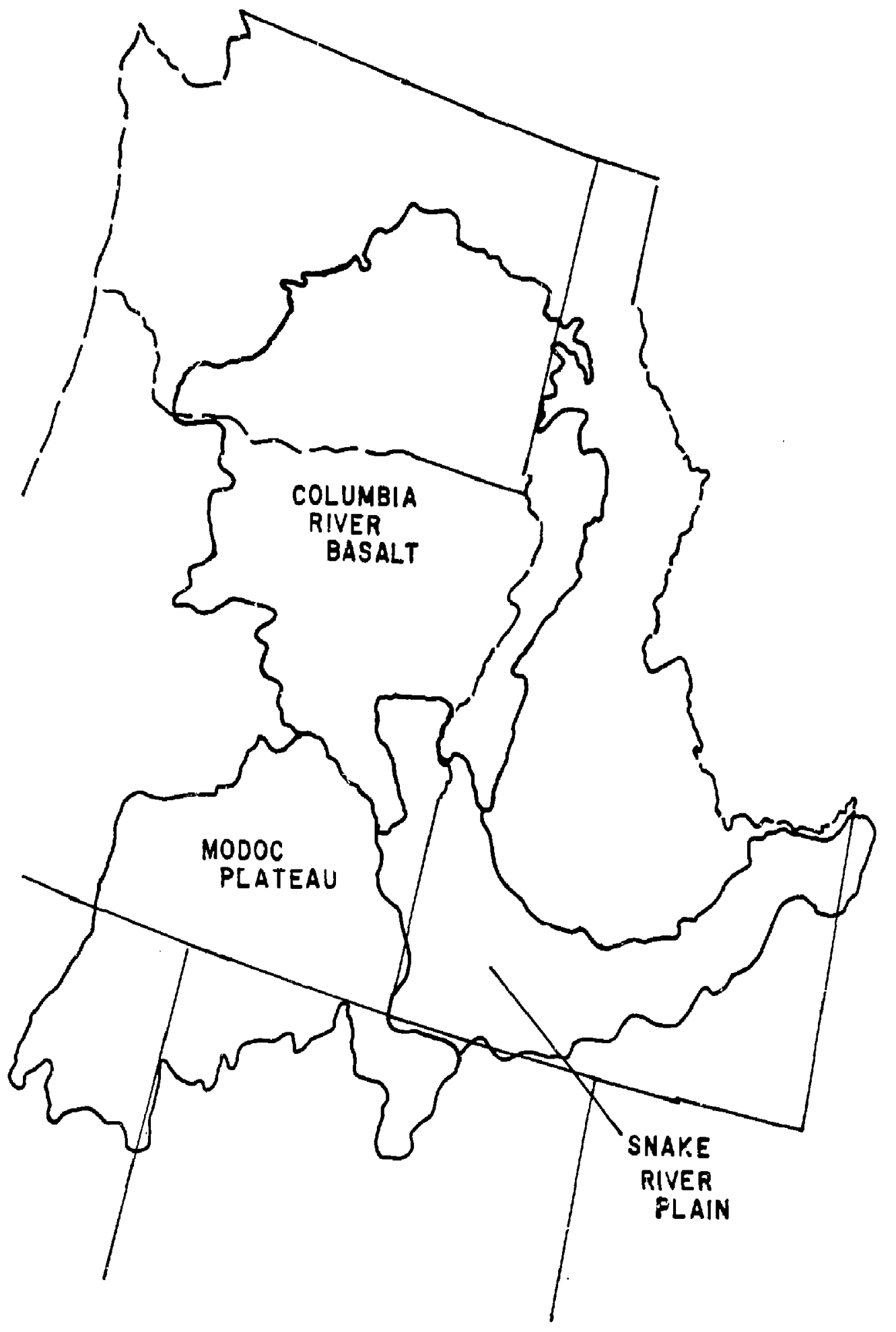

FIGURE 2-2 Flood basalt occurrences chosen for study 


\section{Col umbia River Basalt}

The Columbia River flows cover an area in excess of 150,000 square kilometers in southeast Washington, northeast oregon, and adjacent Idaho with a volume of more than 300,000 cubic kilometers. The thickness of individual basalt flows generally ranges from 1.5 meters to about 61 meters, averaging 24 meters (Newcomb, 1969).

The average thickness of the basalt sequence underlying the Columbia Plateau is greater than 500 meters, and the greatest known thickness is 3,200 meters (Deju, 1977). It consists of a thick sequence of accordantly-layered lava flows and interbedded sediments (Newcomb, 1969). The flows are Miocẹs: to Pliocene in age, and are tholeitic. Repeated eruptions of enormous volumes of basaltic lava filled a slowly subsiding planoconvex basin. Between each eruption, the surfaces of many flows were exposed to erosion.

The Columbia River Basalt is a black to dark-gray, dense, finergrained rock composed mostly of microscopic crystals with some intercrystalline glassy groundmass. the average composition of this basalt is labradorite - 55 percent; augite - 15 percent; magnetite - 15 percent; and brown glass and microlites - 25 percent. Most of the basalt has an even, microgranular texture, but in a few places the crystals are 
so small that the texture is flinty or nearly glassy. The textural fabric of the rock indicates that most of the crystallization occurred after the highly fluid lava had come to rest (Newcomb, 1969).

The two most distinctive petrologic structures in the Columbia River Basalt are layers and joints. The layering resulted from the accumulation of successive flows of highly fluid lava of the same neneral chenical and mineral type. The individual flows are generally separated by: 1) a differencs in jointing, texture, or color; 2) a difference in susceptibility to alteration; 31 interbedded sedimentary material, and/or 41 a vesiculated top and a flinty basal section.

Joints, actual and potential fractures or partings, traverse the basalt. The main sets of fractures were caused by shrinkage of the solidified rock during cooling. The cooling of the lava induced joints that are arranged in: 1) vertical columnar joints, 2) flat or sheeting joints, and 3) unsystematic miscellaneous partings. These joints separate some parts of flows into angular, irregular blocks of all sizes and shapes (Newcomb, 1969). Columnar jointiry systems are present in almost every flow. 
In addition to the shrinkage joints, the basalt is traversed by regional joints. These long, straight sets of parallel vertical cracks trend in various patterns actoss most of the basalt. They are believed to be extension fractures (Newcomb, 19691.

The basalt has a thin, oxidation skin on all but newly-exposed surfaces. rere basalt has been exposed, it may be weathered to depths of up to 50 and 60 meters (Newcomb, 1969).

\section{Snake River Plain Basalt}

The Snake River Group extends over an area of more than 20,720 square kilometers in central 3nd southern Idaho (walker, 1964). It consist: mainly of an accumulation of basalt llows with intercalated lacustrine and alluvial sediments. The basalt fills a huge graben and is known to be more than 1,500 feet thick (Walker, 1964; Nace et al, 1972).

The eruptions that emplaced the basalt were intermittent. The sheet of lava that spread out during each event usually solidified before the next overlying sheet was lajd down. Each sheet has an upper and lower chilled zone. Commonly, the surface of a flow was exposed to erosion or deposition of sediments between the lava flows (llalker, 1964). The molten basalt was fluid enough to spread many miles on relatively low gradients. 
The structure, chemistry and minerology of the Snake River Basalt is similar to the Columbia River Basalt. The major, regional fractures in the basalt are vertical and trend north-south, east-west.

\section{The Modoc Plateau}

Tne Modoc Plateau is the area east of the Cascade Mountains in southern oregon and northern California and west of the Basin and kinge Provinces. The area contains extensive volcanic flows and is a "transition zone" between the Cascade Mountains and the Basin and Range Provinces. The rocks of the plateau are mainly from lava flows that range in composition from rh:olite to basalt (MacDonald, 1966). Tuff, ignimbrite, agglomerate, diatomite, shale, siltstone, sandstone, and gravel are interstratified within the lava flows in varying degrees while many recent cinder cones rest on their surfaces. Lassen Crater, the sight of the last eruption in the contiguous United States (1914), is located on the Modoc Plateau.

The oldest flows are Miocene or Oligocene in age while the youngest are recent (MacDonald, 1965). The major basalt flows are the Warner Basalt (Miocene', Steens Basalt (Miocene), Picture Rock Basalt (Pliocene), and Hayes Butte Basalt (Pliocene). Every flow does not underlie the entire 
area. Individual flows commonly fill grabens and their surfaces are distinguished by pahoehoe or ropy lava structures.

These Tertiary basalts are usually composed of cark-gray olivine basalts. Commonly, the texture of the basalt is porphyritic with phenocrysts of olivine or labradorite (Hampton, 1961).

Faults trending north to northwest are common and usually delineate horsts and grabens. These normal high-angle faults show considerable displacement, up to 305 meters, and some strike-slip displacement (MacDonald, 1966). The fault surfaces can be undulating or angular. Minor faulting can be seen perpendicular to these faults.

Vertical shrinkage joints are very common, especially in the tops or bottoms of each individual flow. Individual flows range from 3 to 15 meters thick. The thickness of the major basalt flows vary from a few tens of meters to over 300 meters, and generally thin toward the south and east (Piper, 1939; MacDonald, 1966; Brown et al, 1962). 


\subsection{REFERENCES}

Brown, S.G. et al, 1962, Ground Water Resources of Cow Valley, Malheur County, Oregon, USGS, WSP., 1619-M, p. M1-M35.

Carmichael, I.S.E., Turner, F.J., and Verhoogen, J., 1974, Igneous petrology: McGraw-Hill, New York, p. 740.

Deju, R.A., P.A. Eddy, M.W. Grutzeck, and C.W. Myers, 1977, Environmental factors needed to establish the geotechnical feasibility of storing radioactive waste in Columbia River Basalt: U.S. Dept. Energy RHO-Sm-8, p. 11.4 .

Diery, H.D. and B. Mckee, 1969, Etratigraphy of the Yakima Basalt in the Type Area, ini Northwest Science, V. 43, No. 2 .

Gary, M., and others, eds., 1972, Glossary of geology: Am. Geol. Inst., p. 805.

Greeley, R., and J. King, 1975, Geologic field guide to the quarternary probes of S-C, Snake River Plain, Idaho; Geo. Soc. of America, Rocky Mountain Section.

Hampton, E.R., 1961, Geologic factors that control the occurrence and availability of ground water in the Fort Rock Basin, Lake County, Oregon: U.S. Geol. Survey Prof. Paper 383-B, p. 29.

Hess, H. H., and Poldervaart, A., 1967, Basalts: Interscience, Iondo.., V. 1\&2, p. 862 .

Leet, L.D. and Sheldon Judson, 1971, Physical Geology, 4th Ed., Prentice Hall, Inc., New Jersey.

MacDonald, G.A., 1966, Geology of the Cascade Range and Modoc Plateau, in Geol. of Northern Californiai California Division of Mines, Geol. Bull, No. 190, Bailey, E.H., ed., p. 65-96.

Meinzer, 0.5., 1942, Hydrology, McCraw Hil1, New York, p. 712.

Nace, R.L., M. Deutsch, and P.T. Voegeli, 1972, Physical environment of the Nation Reactor Testing Station, Idaho a summary: U.S. Geol. Survey Prof. Paper 725-A, p. 38 . 
Newcomb, R.C., 1969, Effect of tectonic structure on the occurrence of ground water in the basalt of the Columbia River Group of the Dallas Area Oregon and Washington: U.S. Geol. Survey Prof. Paper 383-C, p. 33.

Piper, A.M. et al, 1939, Geology and Ground Water Resources of the Harney Basin, Oregon, USGS, WSP, 841, p. 1-187. , 1975, Hypothetical prototype sites of repositories for radioactive wastes: flood basalt, USERDA Y/OWI/SUB-3745/6.

Spock, L.E., 1961, Guide to the Study of Rocks, 2nd Ed., Harper and Row, New York, p. 298.

Stearns, H.T., L. Crandall, and W.G. Steward, 1938, Geology and ground-water resources of the snake River plain in southeastern Idaho: U.S. Geol. Survey Water-Supply Paper 774, D. 268.

Iravis, R. L., 1956, Classification of rocks: Colorado School of Mines Quart., v. 50, No. 1, p. 98.

Walker, E.H., 1964, Subsurface geology of the National Reactor Testing station, Idaho: U.S. Geol. Survey Bull., 1133-E, P. $2 \hat{2}$.

Yoder, H.S., Jr., 1976, Generation of basaltic magma:

National Acad. Sci., Washington, D.C., p. 265. 
GEOMECHANICS OF BASALTS 


\subsection{INTRODUCTION IO GEOMECHANICS OF BASALT}

Basalt is described as a fine.grained, sometimes glassy, basic igneous rock with essential minerals of calcic plagioclase in pyroxene with a silica content generally less than 50\%. Sometimes gaboro, norite, diabase, dolerite and basaitic glass are included in a general discussion of basalt. These rock types are all of similar chemical and mineralogical composition with the grain size being the main distinguishing feature (Agapito and Hardy, 1977).

The engineering behavior of basaltic flows is expected to vary widely due to their unique depositional and cooling sharacteristics. Variations within a flow are largely ?. function of the flow thickness which determines the rate of cooling throughout the mass. Normally, thick flows have dense basalt in their lower portions and are jointed. The jointing forms 5- or 6-sided columns with individual columns averaging 0.6 to 0.9 meters across. Cross joints either inclined or normal to the column may also be present loffice of Nuclear Naste Isolation, 1978).

In the Columbia River basalt, columnar joints are the most common internal structures within individual flows. Although. the pattern of columnar jointing exhibits variability, both within and between flows, a typicai flow usually has a lower zone, which is generally $1 / 3$ to $1 / 2$ of the entire thickness 
of the flow and consists of rearly symmetrical columnar joints, and an upper 2one, which is generally $1 / 2$ to $2 / 3$ of the entire thickness of the flow, consisting of an irregular jointing pattern. The jointing pattern variations include fan-like columar joints, plating joints, swirlirg joints, brick-bat joints, cross joints, and others. Abrr. lateral changes in joint patterns can occur. .. rep. ${ }_{1}$, most joints and fractures are filled with secondary minerals such as zeolite, amorphous iron-rich silicates, and ferro-magnesium clays. The top of the flow may be a slaggy, ropy, or clinkertype basalt (office of Nuclear Waste Isolation, 1978).

Hence, the geomechanical behavior of the basalt flows depends upon the zone being studied. Potent.-al reposicory sites would logically be located in the most massive part of the flow, where the joints are the most widely spaced, and the streng in is the greatest. The behavior of the joints will certainly be a major consideration. The types of geomechanical factors which will be included in any study of basalt as a potential repository rock are indicated in Table 2-2. Note that it includes defining the major structural properties of the rock-mass as well as characteristics of the rock on a much smaller scale.

The geotechnical factors that influence design have been summarized very well in the report prepared by Parsons, 


\section{IABLE 2-2 Geomechanical factors to be considered}

\section{TECTONICS AND SEISMOLOG:}

1. Assess the tectonic stability of the region.

2. Define major faults, fractures, and fissures.

3. Document the seismic record.

4. Assess the structural integrity of the basale mass.

5. Define the frequency, orientation, and character of major lineaments

6. Define the frequency and orientation of fractures in basalt.

7. Define the extent of folding and the forces that led to its present state.

\section{ROCK PROPERTIES AND STRAIIGRAPHY}

1. Def ine the petrographic, mineralogic, and chemical characteristics of the basaits.

2. Assess the stratigtaphy and define variarions.

3. Define erosional stability over geologic time.

4. Define the thermal properties of basalt (expansion, conductivity, and fracture potential).

5. Assess the effect of thermal stre s Scime as for II-4. gradients on fractures and basalc properties.

6. Assess the effect of fractures on the heat transfe: properties of the basalt mass,

7. Examine the effect of radiation on Same as for II-4. otructural incegrity of the basalts.
Source: R.A. Deju et al, 1977

Reglonal geology; field studies; evaluéton of seismic records; seismic monicoring; literature survey; geophysical surveys.

Field studies in outcrops, trenches, and boreholes; remote sensing; literature survey; geophysical surveys.

Examination and documentation of the seismic record, including microearthquake studies.

Field analyses; laboratory and insitu tests; geophysical surveys.

Remote sensing.

Core analysis, suprlemented by borejole geophysics.

Integration of geologic and geçhysical data.

Petrographic, mineralogic, and chemical analyses of selected basalt flows;

literature survey.

Stratigraphic correlation using petrographic, tineralogic, chemical, paleomagnetic, and geophysical techniques.

Regional geology, interpretation of observations; geologic history; geomorphological studies.

Laboratory tests on cores under simulated conditions.

Same as II-4. 
Blinckerhof et al, 1978 (PBQ6D). Their discussion is included

in its entirety below as it sets the basis for the more

detaled discussions of the individual factors that follow:

"Geotechnical Factor's That Iniluence Design

Because of the geological characteristics and general stratigraphic setting of insitu basalt, the choice of basalt for a repository will influence many of the design and layout features of the surface and subsurface facilities as well as the amount of waste that can be stored.

The basis for design decisions in basalt are underiain by the objective to keep the total of all stress components significantly below the threshold value required for the occurrence of an initial failure mechanism. The characteristics that would significantly impact the design of the waste storage facility include:

- Effects of heat on rock strength

- Rock movement and faulting

- Room and piliar stability

- Ground-water movement

- Rock hardness

\section{Effects of Heat on Rock Strength}

At high temperatures, the strength of rock is aiminished as the rock crvatalline structures begin to break down. In basalt, major losses of strength are expected to occur at around $400^{\circ} \mathrm{C}$ to $500^{\circ} \mathrm{C}$. To prevent weakening of the rock adjacent to the waste packages and the concomitant problems it would pose to retrievability, the thermal loading should be adjusted so that temperatures do not exceed ritical values in large volumes of rock in the immediate vicinity of the canisters.

To maintain room safety and to reduce the possibility of progressive spalling failures, the temperature of the rock surfaces in the room walls and roof should also be held below the values that cause excessive strength loss. 


\section{Rock Movement}

The rock surrounding and overlying the repository would react or move in response to the stresses imposed by the mined excavation and by thermal loading from the implar.ted waste matertals. Mining activities world cause the surrounding rock to subside or move into and towards the mined opening. In contrast, the thermal loading would expand the rock and cause heaving to occur.

The repository laiout and geometry and the allowable thermal loading should be designed to minimize rock movements so that the safety or integrity of the shafts is not adversely affected. Movements at the ground suriace should be less than that which would cause distress in any structure. In addition, rock movement should not cause disruption or shearing of any aquifers in the vicinity of the repository.

Room and Pillar stability

When basalt is overstres ed, it will fail quickly with comparatively little warning. Accordingly, the main philosophy used in escablishing d-jign guidelines for waste facilities was to jimit stresses to a value well below the level required for initial failure.

\section{Room Stability}

The repository layout and geonetry and thermal loading limits are chosen such that the ratio of rock strength to rock stress within any rock cube with one face exposed in the wais of the room and with dimensions equal to $20 \%$ of the mean tunnel diameter was two or greater. Rock strength is defined as the mean compressive strength of the rock mass, considering the confining pressures, the offsets of fractures and joints, and temperatures. Rock stress is the mean compressive stress including a combination of the virgin stresses, stresses developed by the opening, and thermal stresses.

Analytical studies indicate that the room stability guidelines were met for the generic repository in basalt at the proposed 2,900 ft. $(660 \mathrm{~m})$ depth. Therefore, additional s'is furt (rock bolting: would be necessary only in localized areas where loose rock ir observed. 


\section{Pillur Stubility}

The repository layout is designed such that the ratio of pillar strength to pillar stress remains greater thar two. This ratio is defined as the mean compressive strength of the pillar at mid-height. To protect against blast damage, the pillars were desigr with a minimum width of $20 \mathrm{ft}$. In all cases, the pillar width was designed to be at least equal to t ie height of the room." (PBQ\&D, 1978)

Pleasa note that within the section on "Room Stability". definiti $s$ of rock strength and stress are given in tho first paragraph. It must be stated that, at the present time, there is no universally accepted way of estimating rock-mass strength nor is there agreement as to how the stress around an opening should be calculated. Furthermore, the $20 \%$ cr:teria which has been used is not one found widely in the literature, Iittle field data is available to provide the required substantiation. This will be discussed in more detail later.

Based on analytic studies done by Herdy and Hockirig, 1977, $P B Q E D$ arrived at three hypothetical designs shown in Figure 2-3, which are to meet the canister criteria recomulations indicated it. Table 2-3. The local areal therulal loading, which would apply from the theoretical calculations, are shown on Table 2-4. These are compared with "allowable areal thermal ioading." The designs were based on thenmal modeling of the type that will be discussed later in this report. The basis for selecting "allowable level guidelines" is not given in $t^{+}$? report. Factual data on the thermalmechanical properties of various basalt flows and formations 


\section{BASALT}

CYCLE I

HLW: Extraction Rotio $=25 \%$

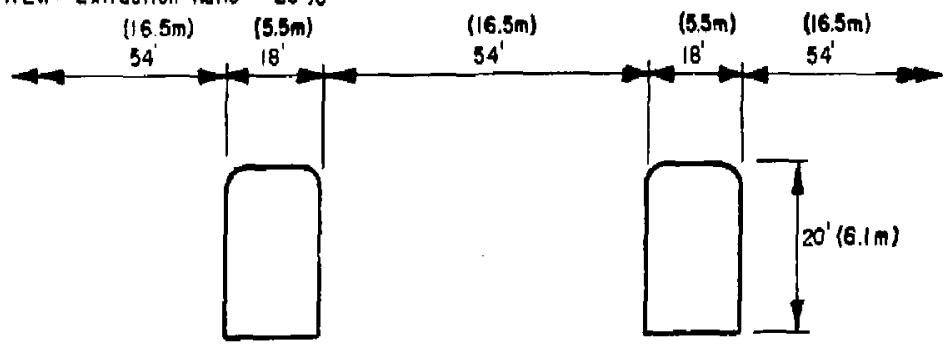

ILW CW: Extraction Ratio $=40 \%$

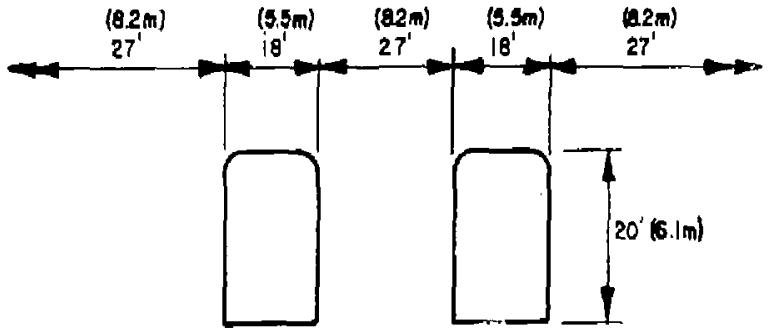

CYCLE II

PWP / BWR: Extroction Rollo $=40 \%$

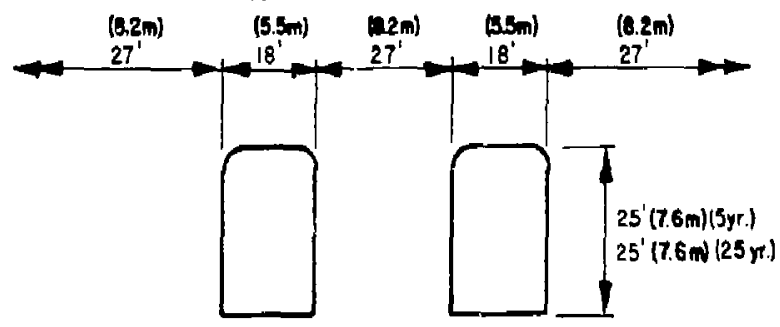

CYELL III: SOME OS CYCLE I

FIGURE 2-3 Extraction Ratio Chart

Source: PQQSD, 1978. 
TABLE 2-3 Canister recelpt crlterla recummendations.

\begin{tabular}{|c|c|c|c|c|c|c|c|c|c|}
\hline \multirow[b]{3}{*}{ Conts $\underline{\underline{s}}$} & \multirow{2}{*}{\multicolumn{2}{|c|}{ Cantster }} & \multirow{2}{*}{\multicolumn{2}{|c|}{ Overpack }} & & \multicolumn{4}{|c|}{ Max1mum RadiatLon Level (rem/hr) } \\
\hline & & & & & & At & face & $3.05 \mathrm{~m}$ fron & Ctr. LAne \\
\hline & $\begin{array}{c}\text { Outside } \\
\text { Diameter } \\
\text { m } \\
\end{array}$ & $\begin{array}{c}\text { Overall } \\
\text { Length } \\
\text { m } \\
\end{array}$ & $\begin{array}{c}\text { Outside } \\
\text { Diamerer } \\
\text { m } \\
\end{array}$ & $\begin{array}{c}\text { Overiall } \\
\text { Lerigth } \\
\mathrm{m}\end{array}$ & $\begin{array}{c}\text { Age } \\
\text { (Yoars) } \\
\end{array}$ & $\begin{array}{c}\text { gamma } \\
\text { dose rate }\end{array}$ & $\begin{array}{l}\text { neutron } \\
\text { dose rate }\end{array}$ & $\begin{array}{c}\text { gamma } \\
\text { dose rate }\end{array}$ & $\begin{array}{l}\text { reutron } \\
\text { dose rate }\end{array}$ \\
\hline $\begin{array}{l}\text { HLW In } \\
\text { Glass }\end{array}$ & .324 & 3.048 & .356 & 3.35 & 10 & $2.0 \times 10^{5}$ & $1.0 \times 10^{2}$ & $1.0 \times 10^{4}$ & $1.0 \times 10^{1}$ \\
\hline $\begin{array}{l}\text { HLW in } \\
\text { Calcine }\end{array}$ & .219 & 3.048 & .273 & 3.35 & 10 & $5.0 \times 10^{5}$ & $1.0 \times 10^{2}$ & $5.0 \times 10^{4}$ & $1.0 \times 10^{1}$ \\
\hline IL-TRU & .324 & 3.048 & .356 & 3.35 & 5 & $1.0 \times 10^{2}$ & $1.0 \times 10^{-1}$ & $1.0 \times 10^{1}$ & $5.0 \times 10^{-3}$ \\
\hline Cladding & .324 & 3.048 & .356 & 3.35 & 5 & $1.0 \times 10^{3}$ & $1.0 \times 10^{-1}$ & $1.0 \times 10^{1}$ & $5.0 \times 10^{-3}$ \\
\hline PWR & .356 & 4.877 & .406 & 5.03 & 10 & $7.0 \times 10^{4}$ & $1.0 \times 10^{1}$ & $3.5 \times 10^{3}$ & $5.8 \times 10^{-1}$ \\
\hline BWR & .273 & 4.877 & .324 & 5.03 & 10 & $5.0 \times 10^{4}$ & $1.0 \times 10^{1}$ & $2.5 \times 10^{3}$ & $5.8 \times 10^{-1}$ \\
\hline
\end{tabular}

Max. Welght (incl. Overpack) $=6.613 .8 \mathrm{~kg}$.

Max outer surface contamtnation

with transferable radiolsotopes:

beta-gamma radiation emitting nucl ldes:

alpha emfteing nuclides:

$10,000 \mathrm{dis} / \mathrm{min} / \mathrm{dm}_{2}^{2}$
$300 \mathrm{dis} / \mathrm{min} / \mathrm{dm}^{2}$ (disintegration/minute/loo centimeters ${ }^{2}$ )

Source: PBQED, 1978 
TABLE 2-4 Local areal thermal loading basalt.

\begin{tabular}{|c|c|c|c|c|}
\hline Cycle & Haste Type & $\begin{array}{l}\text { Average } \\
\text { KW/can } \\
\end{array}$ & $\begin{array}{l}\text { Allow. Areal } \\
\text { Thermal Loading }\end{array}$ & $\begin{array}{c}\text { Design Areal } \\
\text { Thermal Loading }\end{array}$ \\
\hline I & HLW & 1.2 & $190 \mathrm{w} / \mathrm{m}^{2}$ & $189 \mathrm{w} / \mathrm{Ta}{ }^{3}$ \\
\hline II & PGR & 0.55 & 190 & $627 *$ \\
\hline & $\mathrm{BhR}$ & 0.18 & 190 & $142 *$ \\
\hline II & PWR & 0.55 & 80 & 79 \\
\hline 117 & BWR & 0.18 & 80 & 78 \\
\hline III & $\begin{array}{l}\mathrm{HLW}+\mathrm{Pu} \\
\text { (glass) }\end{array}$ & 1.2 & 190 & 189 \\
\hline
\end{tabular}

*Design areal thermal loading could not be brought up to allowable due to physical restrictions on spacing.

Source: PBQSD, 1978, ․ 14 
is scarce. Developing such data and guidelines is the purpose of the present heater experiments being conducted in the Hanford Basalt.

This report discusses the geomechanical characteristics of basalts in general, providing information about the specific roci types as appropriate. It has been divided into six major sections. These are insitu stress, mechanical properties, thermal properties, thermoelastic properties, other characteristics, and scaling of laboratory results. A great deal of research is underway (with particular reference to the Hanford operation) for evaluating the properties of basalt. These include both laboratory and field studies as well as a large amount of modeling using analytic, finite element, finite difference and other types of models. Because of these activities, progress in evaluating and measuring important geomechanical characteristics should be rapid. 


\subsection{STRESS STATE}

In analyzing the stability of an underground excavation, one must consider the stresses that are applied and the strength of tis materials involved. The stresses can be divided into three sategories. The first is insitu stresses, those that exist prior to excavation. The second is stresses induced by the excavation process itself and the third category includes the stresses that are induced by the materials which are placed within the excavation. prior to discussing each of these categories in some detail, it is perhaps worthwhile to consider the methods by which stresses are evaluated.

Stresses are generally* not measured directly but rather are calculated by introducing strain (or displacement) measurements and suitable elastic constants, into equations developed from elastic theory. The most common and widely accepted means of obtaining insitu stress fields in the U.S. is through the use of the U.S.B.M. borehole deformation gauge. Here a 38 m diameter hole is drilled, a gauge which measures changes in borehole diameter in three directions is inserted, and the hole overcored with a $150 \mathrm{~m}$ ciameter bit. By measuring the borehole deformations, knowing the elastic

\footnotetext{
*The possible exceptions are hydraulic fracturing and flatjack type determinations.
} 
modulus and Poisson's ratio of the rock, and using the equations for a thick walled cylinder, one can calculate stress magnitudes and directions. Three holes are required to determine the complete stress tension at any point. Due to the overcoring requirement, this technique is generally limited to use in relatively short holes $(<30 \mathrm{~m})$. Hence, measurements at depth would be obtained from underground openings, of the other techniques available, many suffer from both operational and calculational difficulties. Results obtained using several techniques at the same location have generally shown wide variations. This may be due to real variations; however, it is more likely due to the instruments/procedures/evaluation techniques employed. Most techniques assume that the rock is linearly elastic and isotropic. This is a good approximation for some rocks, but not good for others. The ditermination of absolute stress or stress changes is compounded by moisture and temperature. For nuclear waste applications, a great deal of development will be required in this area. 


\section{In Situ Stress}

As was stated by Hardy and Hocking, "no stress measurements have been recorded in the basalt flows to our knowledge, but in other parts of the U.S. stress measurements have shown a trend toward lithostatic case at depths of around a thousand meters." (Hardy and Hocking, 1977) The stress measurements referred to by Hardy and Hocking were those compiled by Lindner shown in Figures $2-4$ and $2-5$. Note that no definite "trend" towards a lithostatic stress field at depth is observed. Rather, there are few data points, and those exhibit a wide degree of scatter. A wide scatter is also noted in Figures $2-6$ and 2-7. Lindner and Halpern have fit equations to the data for North America. They found that:

$$
\begin{aligned}
\sigma_{V} & =(9.42 \pm 13.1) \mathrm{kg} / \mathrm{cm}^{2}+(0.339+0.67) \mathrm{kg} / \mathrm{cm}^{2} \text { per m-depth } \\
& =(135 \pm 185) \mathrm{psi}+(1.469+0.289) \text { psi per foot-depth } \\
\sigma_{H} & =(620 \pm 116) p s i+(1.690+0.311) \text { psi per foot-depth } \\
& =(43.6 \pm 8.15) \mathrm{kg} / \mathrm{cm}^{2}+(0.390 \pm 0.072) \mathrm{kg} / \mathrm{cm}^{2} \text { per m-depth }
\end{aligned}
$$

where

$$
\begin{aligned}
& \sigma_{\mathrm{v}}=\text { vertical stress } \\
& \sigma_{\mathrm{H}}=\text { horizontal stress }
\end{aligned}
$$

For the horizontal stress, Lindner comments, "This curve fit is a poor one. The horizontal stress data indicate considerable scatter. Data vary irom three to four times the least-square average, to less than lithostatic. Hence, 


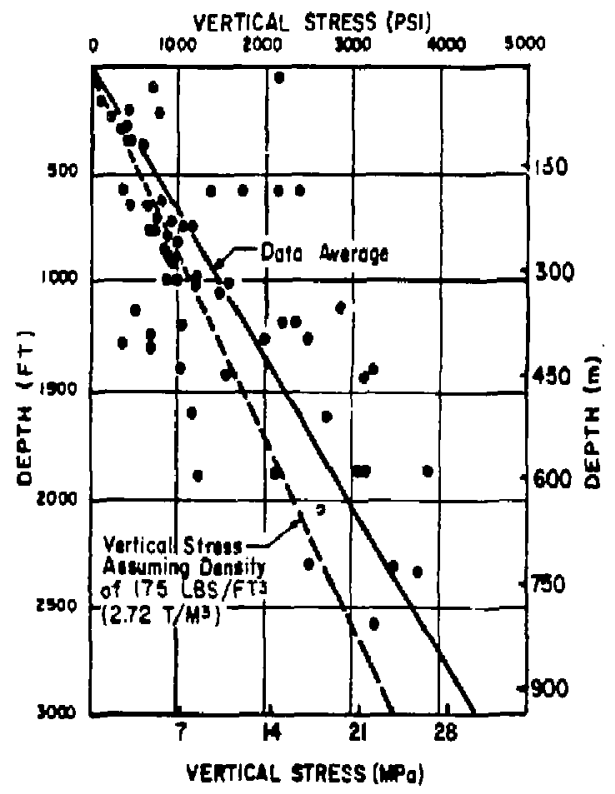

FIGURE 2-4 Vartical stress uith depth Source: Lindner and Halpern, 1977. 


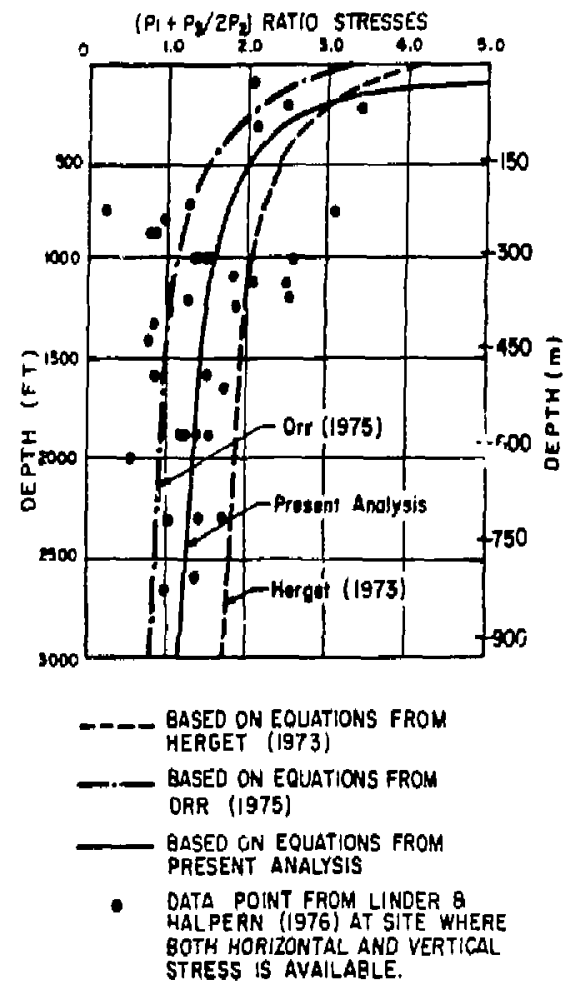

FIGURE 2-5 Ratio of the average horizontal stress to vertical stress

Source: Lindne and Halpern, 1976. 


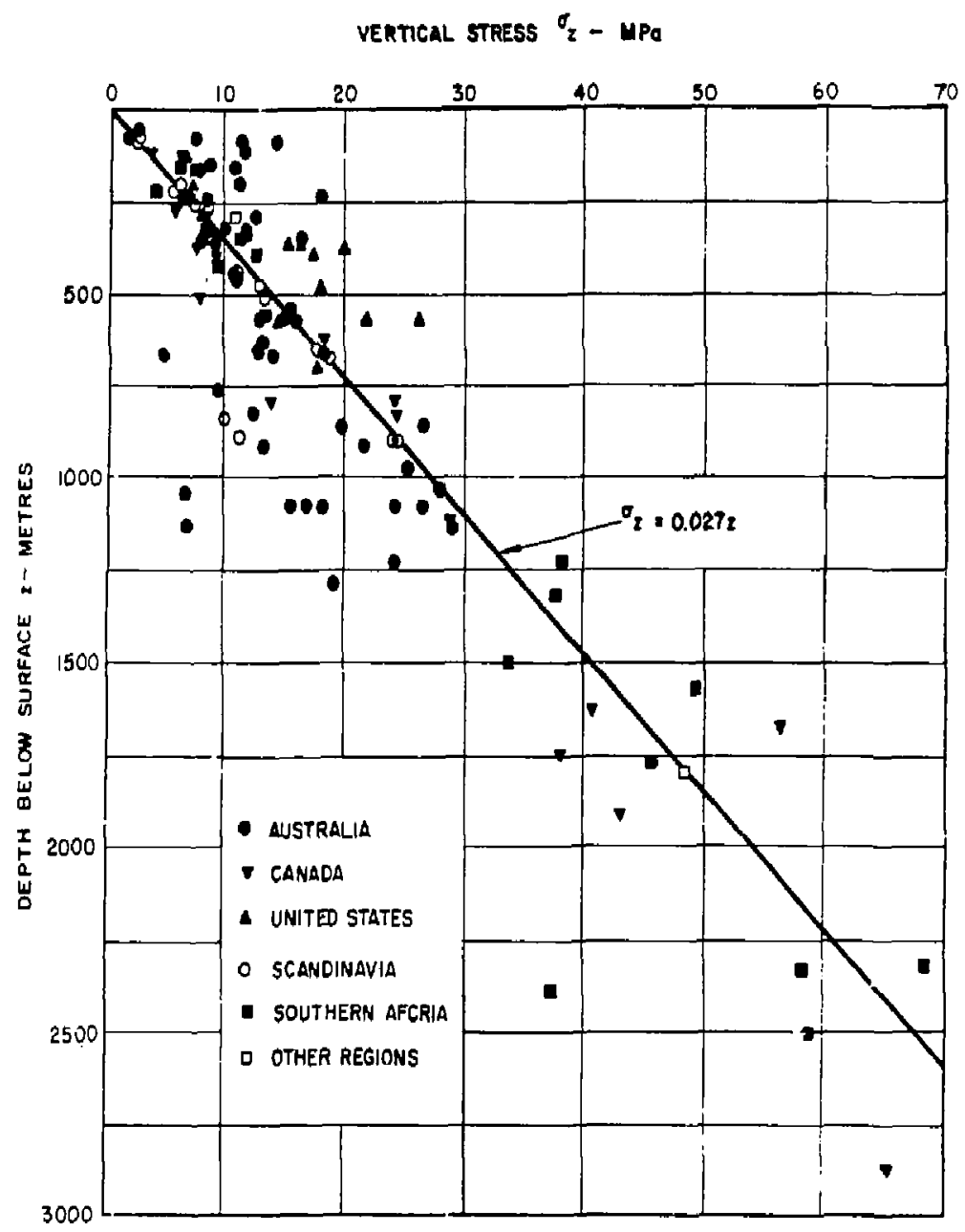

FIGURE 2-6 Plot of vertical stresses against depth below surface Source: Hoek and Brown, in press. 


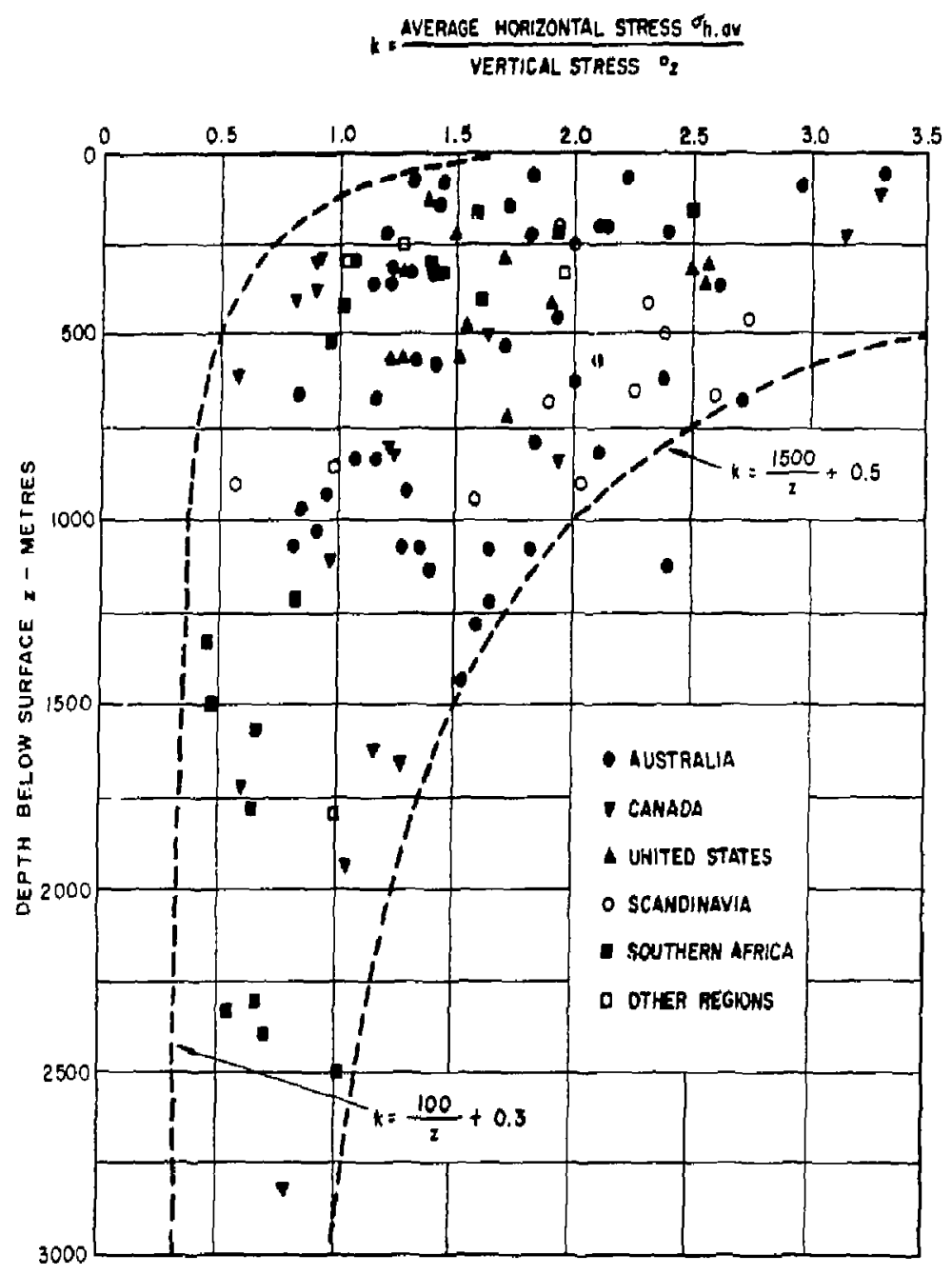

FIGURE 2-7 Variation of ratio of average horizontal stress to vertical etrese with depth below surface Source: Hoek and Brom, 1976. 
the curve fit is at best a trend rather than an average that could be utilized in design."

The presence of the basalts themselves is evidence of previous tectonic activity in the area in which they are found. Therefore, one might expect to find significant deviations from a stress state calculated based on the weight of overburden. However, in the case of lithostatic conditions, the three stresses would be equal to each other and equal to the weight of the overburden. The presence of faults, dikes or other major structures would also affect the irsitu stress field in the vicinity of such a feature. 


\section{Stresses Induced By Excavation}

Hardy and Hocking made a two-dimensional analysis of the effect of various in situ stress fields on the stresses around a typical waste repository room, shown in Figures $2-8$ and $2-9$ using the values given in Table $2-5$. For the base case, it has been assumed that the initial in situ field stresses were 25 megapascals at a depth of 1,000 meters (the horiznntal stress field was assumed to be equal to the vertical). In Figure 2-9, the effect of areal thermal loading on the tangentia.? boundary stresses for the base case is shown for three points around the periphery of the room. The boundary stresses and temperatures for the central room with other in situ stress fields are shown in Figure 2-10. When the horizontal insitu stress is equal to one-half the vertical, the most significant difference between this case and the base case is that the boundary stresses in the roof and floor are very much reducad. Tensile stresses are actually present in the roof. When the in situ horizontal stress is one and one-half times the vertical, the boundary stresses are shown to be much higher in the roof and floor of the rooms when compared to the base case. The boundary stresses in the side wal.s are lower than the base case.

In summary, the boundary stresses in both the roof and floor of the room decrease with decreasing horizontal to 


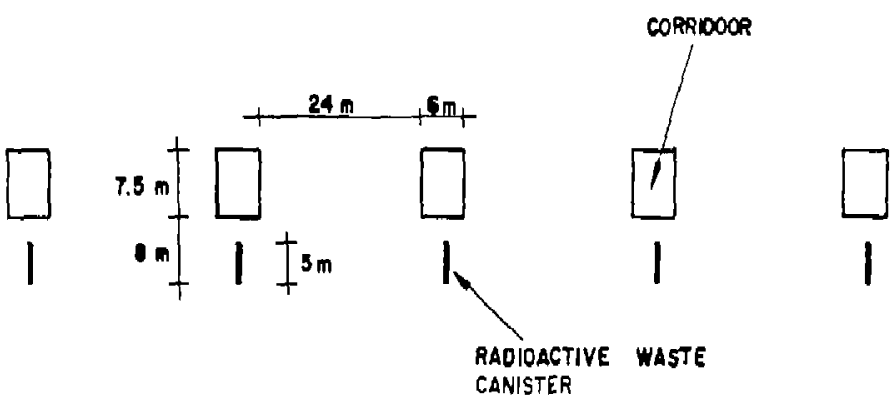

FIGuRe 2-3 Base case for excavation and canister lucation geouetry Source: Hardy and Hocking, 1977. 

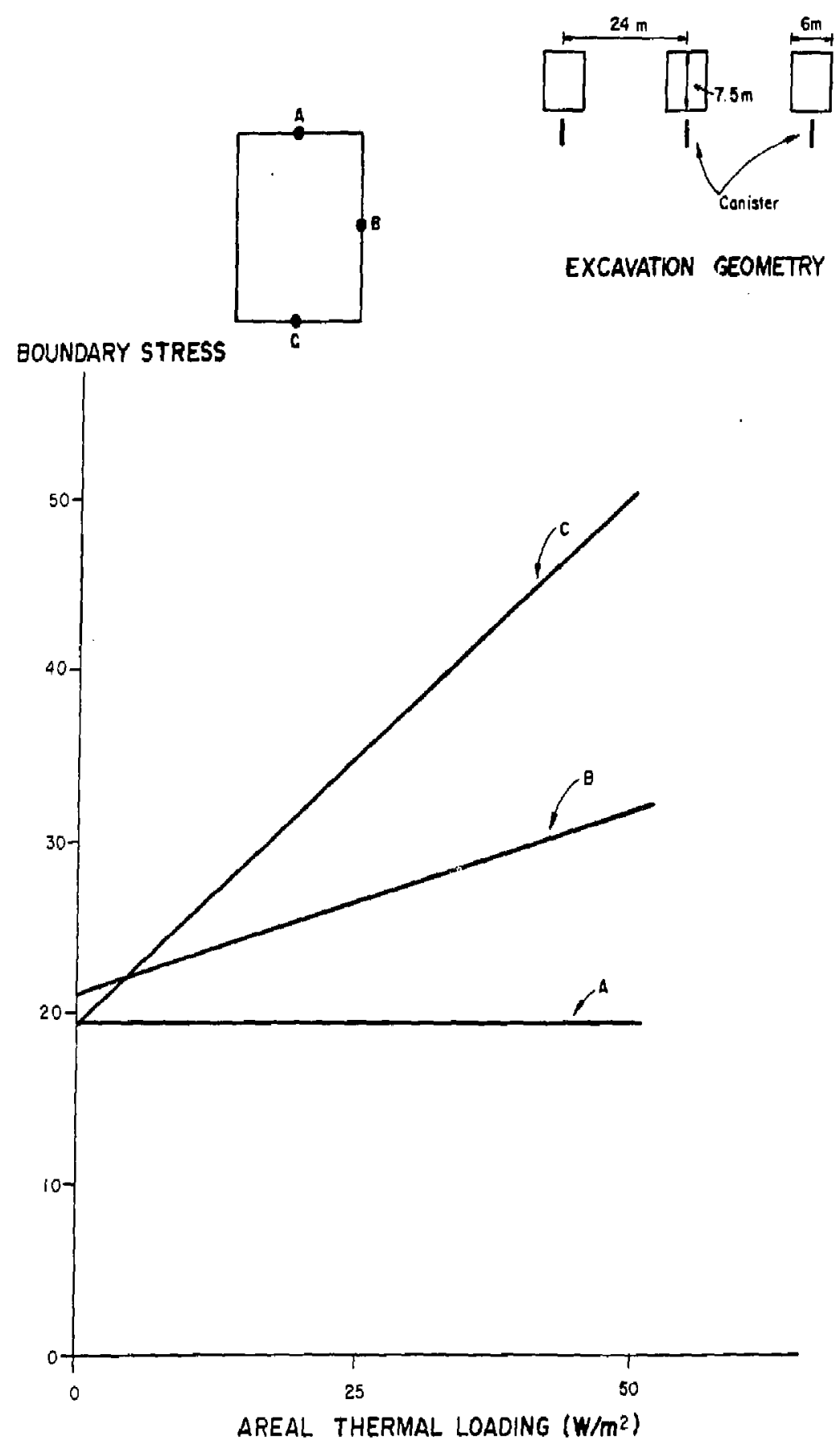

FICURE 2-9 Effect of areal thermal loading on boundary stresses for the base case

Source: Hardy and Hocking, 1977. 
TABLE 2-5 Basalt properties.

Property

Thermal Conductivity $\mathrm{W} / \mathrm{m}^{\circ} \mathrm{C}$

Specific Heat $\mathrm{J} / \mathrm{kg}^{\circ} \mathrm{C}$

Dens1ty $\mathrm{kg} / \mathrm{m}^{3}$

Diffusity ( ${ }^{3} /$ sec $)$

Heat capacity $\left(\mathrm{J} / \mathrm{m}^{30} \mathrm{C}\right)$

Elastic modulus (Pa)

Poisson's ratio
Basalt

1.86

1030

2900

$6.5 \times 10^{-7}$

$3.0 \times 10^{6}$

$0.48 \times 10^{11}$

0.2

Source: Hardy and Hoeking, 1977 


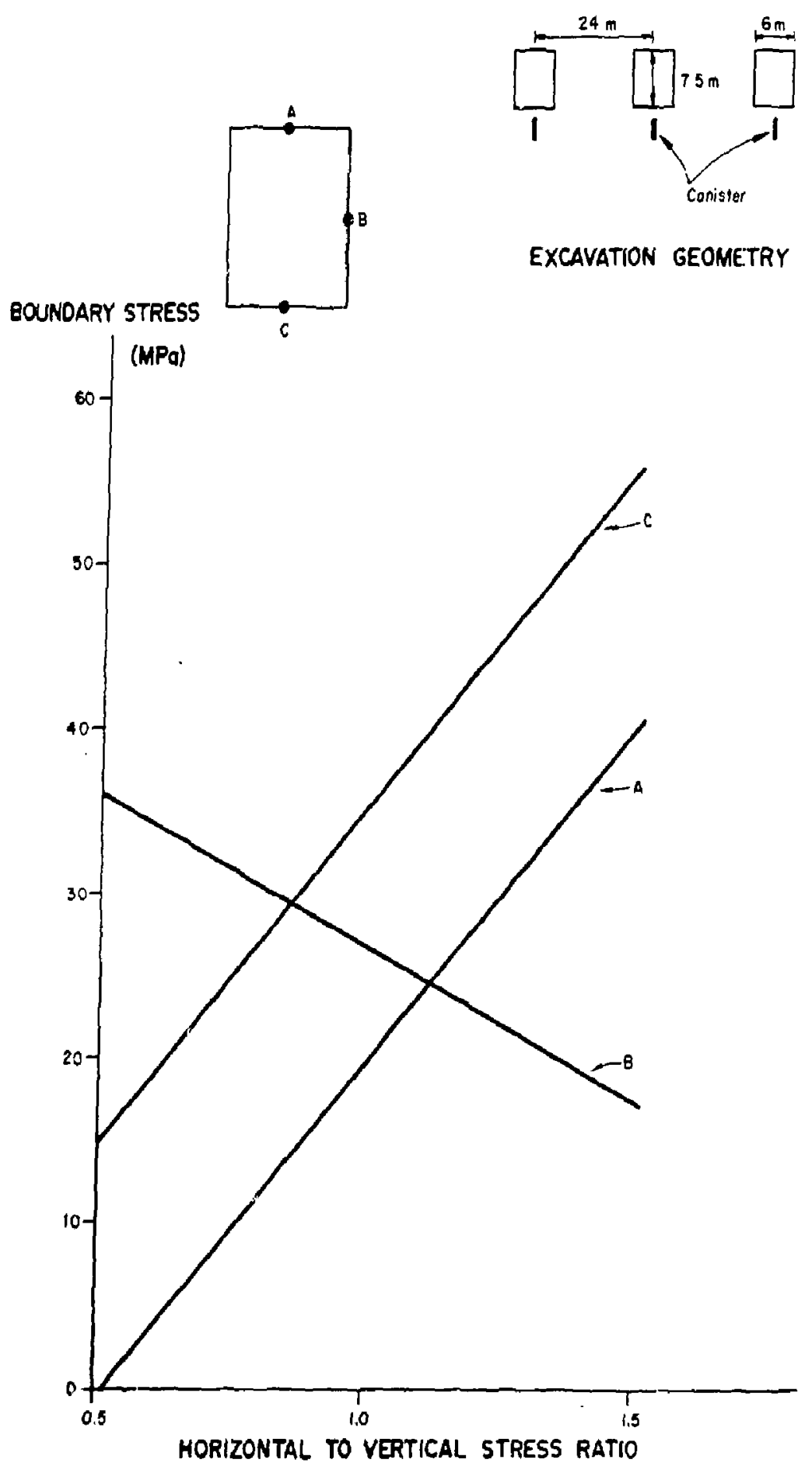

PICURE 2-10 Effect of inditu fleld stress ratio on boundary atresses for base case

Source: Herdy and Hocking, 1977.

$?-1$ 
vertical in situ stress field ratio, whereas, the boundary stress in the sidewall increases with a decreasing stress ratio. Hence, it is very important to know at least the ratios of the major principal stresses, and their direction. At the present time, this information is not available. 


\section{Thermally Induced Stresses}

It is possible, using a thermal-mechanical analysis, to perform a series of parametric studies in order to determine optimum size, shape, support of the rooms, canister location, and placement sequence. At this point, such studies are useful primarily from a scoping viewpoint; that is, to reveal the relative effect of changing one parameter while keeping all others constant. Such a study was done by Hardy and Hocking (1977), and it is felt worthwhile to discuss some of the results. These parametric studies have all been conducted on the base case, shown in Figure 2-8. Note that this is the same geometry, essentially, as was assumed in the PBQ\&D Study. The temperature distribution around the room for an elapsed time of five years is illustrated as contours in Figure 2-11. Note that the contours should be perpendicular to the opening. The fact that they are not is due to the modeling procedure used. The areal thermal loading in this case was 25 watts per square metor, and the air in the room was analyzed as if it was stagnant and no convection or radiation heat-transfer mechanisms were modeled. The thermal st:esses at various points in the basalt around the room are illustrated in magnitude and direction in Figure 2-12. The magnitude of the stresses are measured between the ends of the crosses; tensile stresses being denoted by arrowheads. Only thermal stresses are presented with no account being taken of in situ stress fields. 


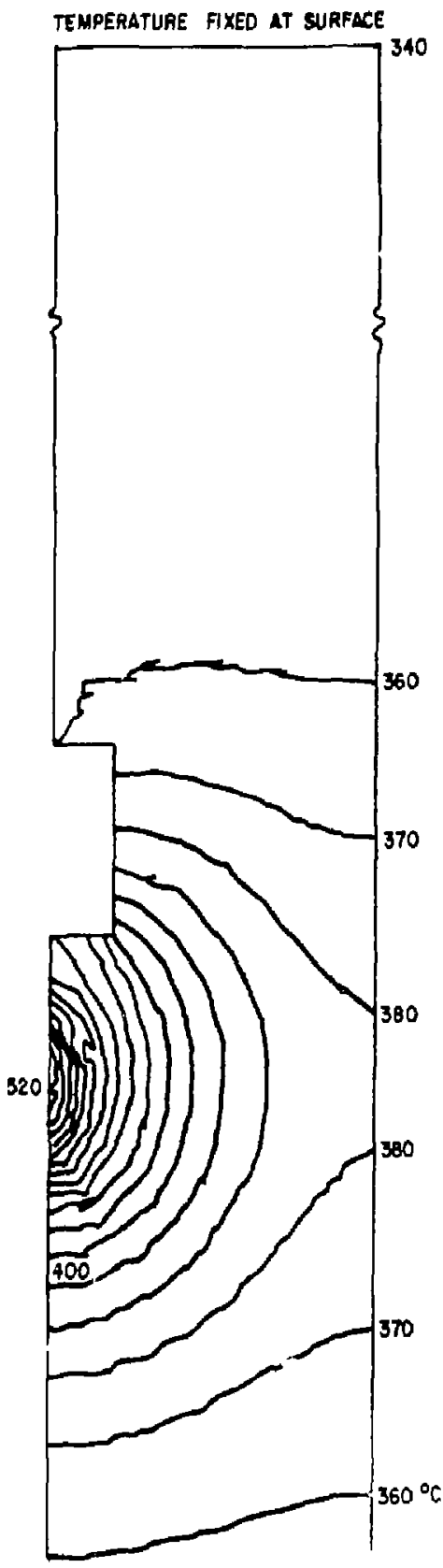

FIGURE 2-11 Temperature contours for elapsed time of 5 years areal thermal loading of $25 \mathrm{w} / \mathrm{M} 2$

Source: Hardy and Hocking, 1977. 


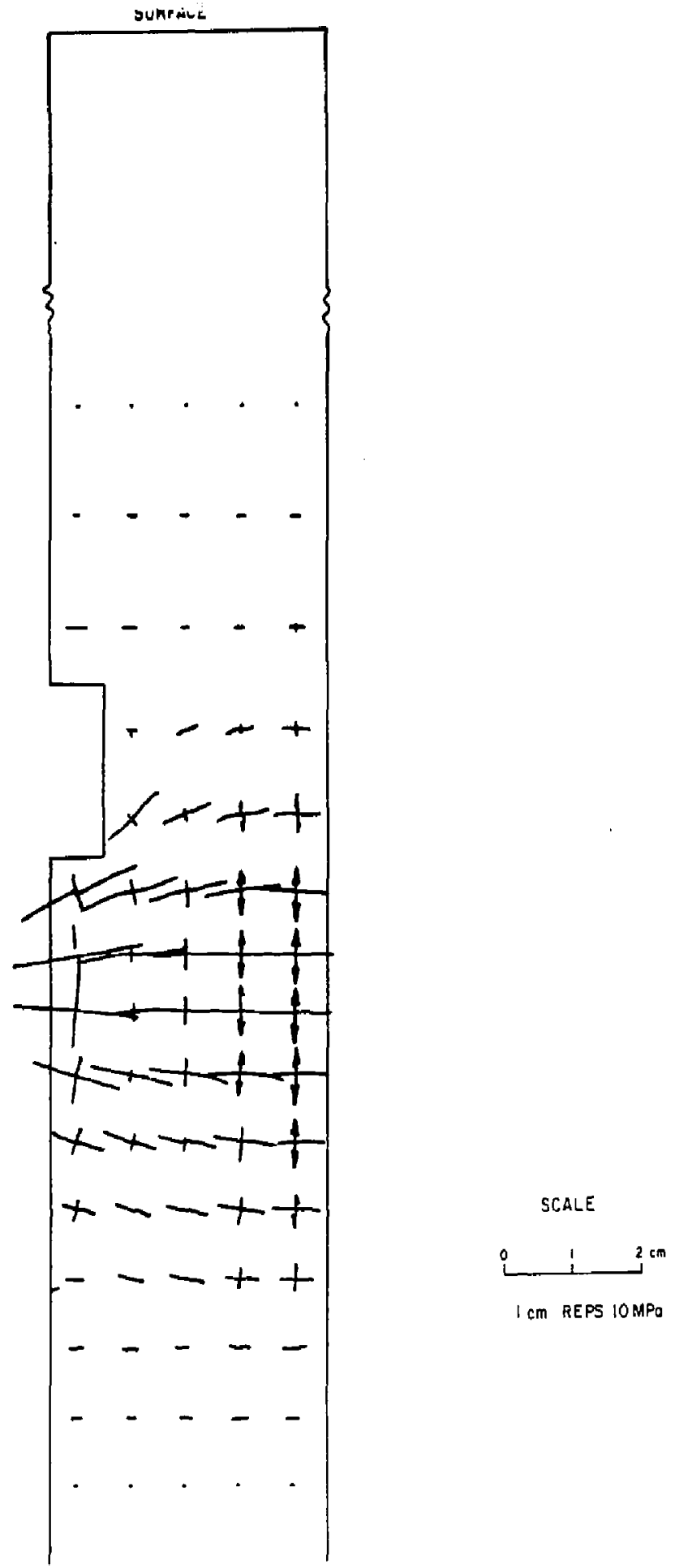

FIGURE 2..12 Stresses for elapsed time of 5 years-areal thermal loading of $25 \mathrm{~W} / \mathrm{M} 2$

Source: Hardy and Hocking, 1977. 
As can be seen in Figure 2-13, rather high stresses occur in the corners of the room. It must be kept in mind, however, that no reduction in modulus or change of thermal properties has been introduced to take into account the blasting damage around the room.

The variation in boundary stresses for the three points a, $k$, and $c$, described earlier, are shown in Figure 2-14 as a function of basalt properties (Poisson's ratio, Young's modulus, and coefficient of linear thermal expansion). A reduction of poissor's ratio from 0.3 to 0.1 results in a maximum: reduction (point $c$ ) of thermal stress by about 11 . The therral stresses vary linearly, with both Young's modulus and the coefficient of linear thermal expansion. This suggests that a good knowledge of Poisson's ratio is not recessary, whereas it is of great importance to know the appropriate coefficient of linear expansion and Young's modulus.

Using this approach, one can also examine the influence of rom shape and the influence of room spacing. Various shapes can significantly affect the boundary stresses in the roof and floor of the room. The effect is sumewhat less on the side. A sumary showing a comparison of boundary stresses at selected points for various configurations and loading is shown in Table --6 . These numbers should all be compared with the base case shown in the first row. 

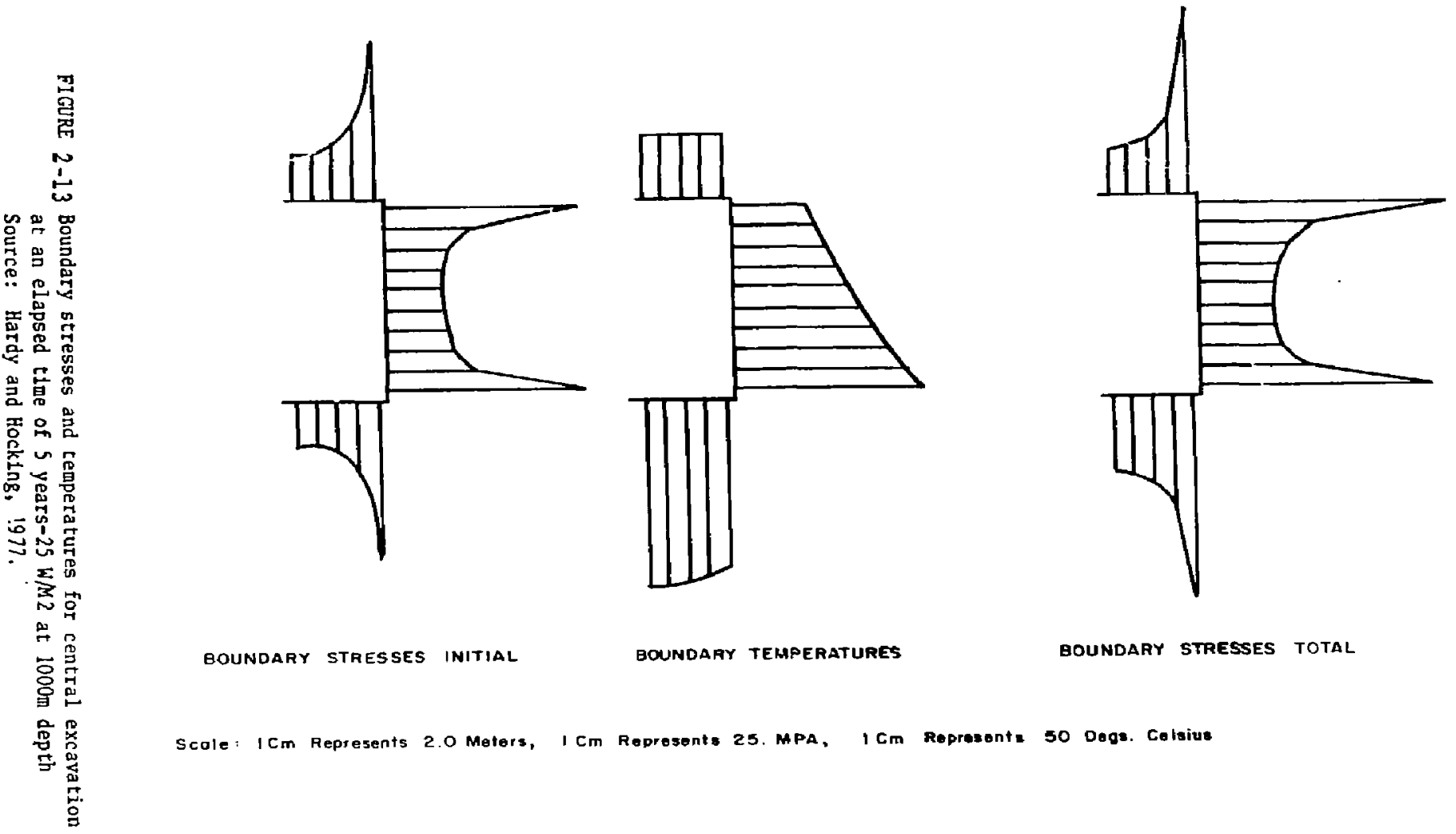

BOUNDARY STRESSES INITIAL

BOUNDAFY TEMPERATURES

GoundaRY STRESSES TOTAL

Scale: ICm Represents 2.0 Meters, I Cm Represents 25. MPA, I Cm Reprasonta SO Oega. Colaiue 

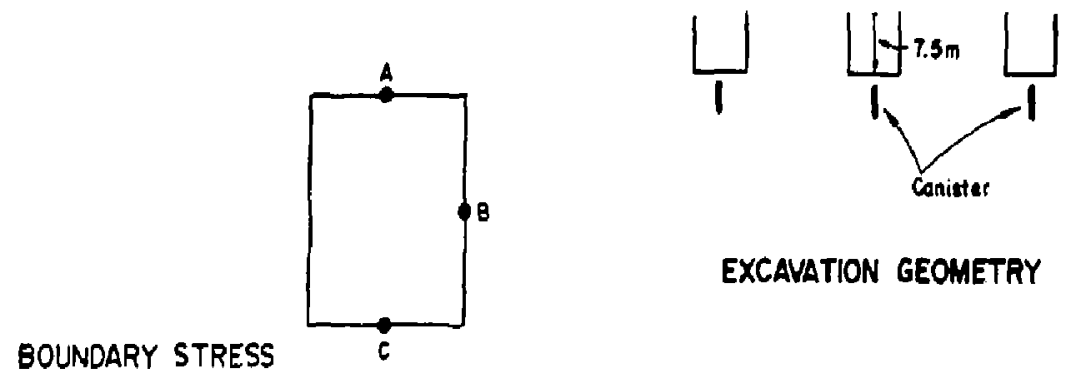

EXCAVATION GEOMETRY

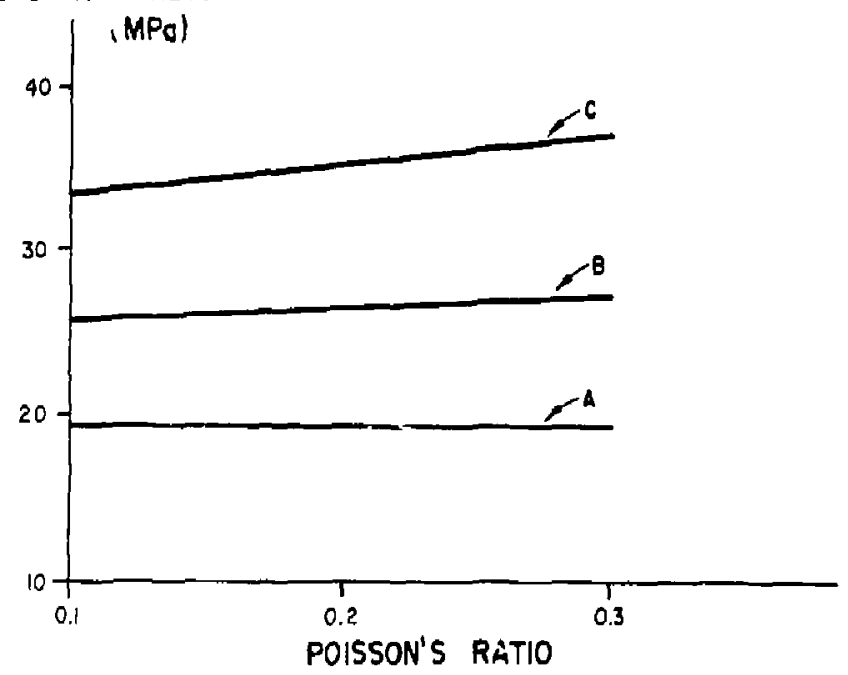

\section{BOUNDARY STRESS}

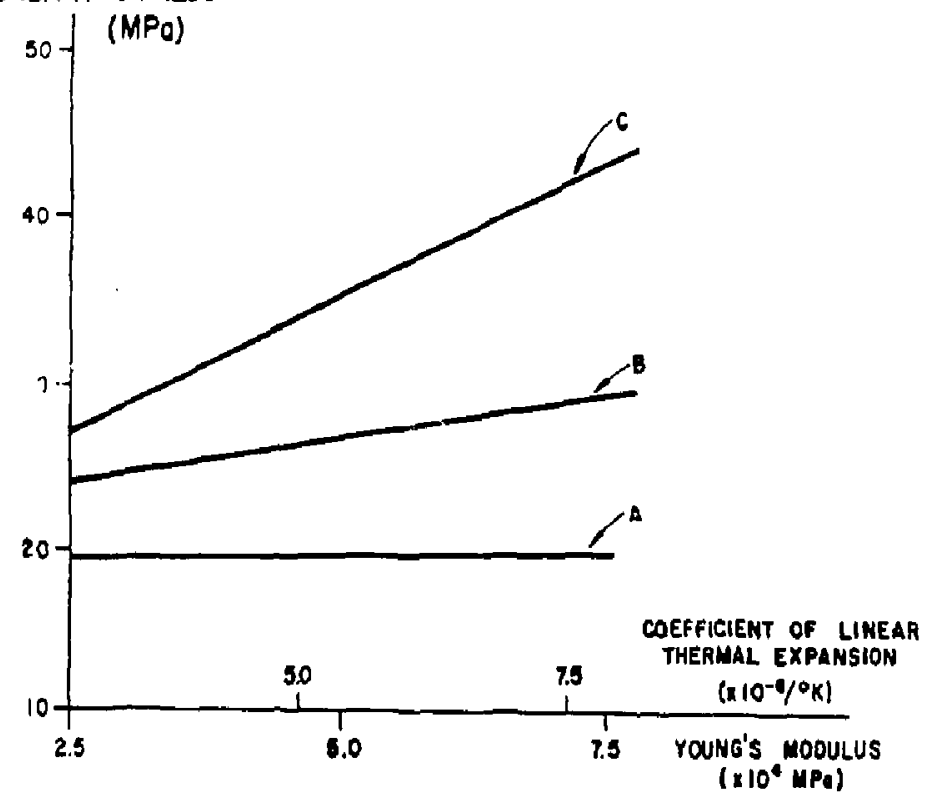

FIGURe 2-14 Effect of bualt thermonechentcal properties on stresees for the base case.

Source: Herdy and Hocking, 1977. 
TABLE Z -6 Comparison of Boundary Stresses at Selected Points for Various Configurations and Loadings

\author{
Location \\ Tangentlal room stress (MPa)**
}

\begin{tabular}{|c|c|c|c|}
\hline Cond1tion & $A^{*}$ & B & $\mathcal{C}$ \\
\hline Base case & 19.5 & 26.6 & 34.9 \\
\hline Thermal loadfug $50 \mathrm{~W} / \mathrm{m}^{2}$ & 19.5 & 32.0 & 50.3 \\
\hline Depth $1400 \mathrm{M}$ & 27.3 & 35.1 & 42.6 \\
\hline$E=$ Tw1ce base case & 19.8 & 32.0 & 51.4 \\
\hline Polsson's ratio 0.3 & 19.7 & 27.0 & 36.8 \\
\hline Poisson's ratio 0.1 & 19.5 & 25.9 & 33.2 \\
\hline Insitu horizontal 0.5 vertical & -0.7 & 36.0 & 14.7 \\
\hline Insitu ho"1zontal 1.5 vertical & 39.7 & 17.3 & 55.1 \\
\hline Cantster relocation & 24.8 & 19.9 & 31.0 \\
\hline Roow shape & 64.2 & 30.0 & 34.1 \\
\hline Canister placement sequence & 23.8 & 26.3 & 41.2 \\
\hline $\begin{array}{l}\text { At end of retrieval perlod (25 years) } \\
\text { ^From F1gure } 2-13 \\
\star \star 1 \mathrm{MPa}=145 \mathrm{Ibs} / \mathrm{in}^{2}\end{array}$ & 45.9 & 20.4 & 66.4 \\
\hline
\end{tabular}


In conclusion, one can presently perford scoping studies such as have been described by Hardy and Hocking to provide an indication of the importance of various variables on the stress distribution around an underground excavation. One can investigate in situ stress, the induced stress due to the excavation, and thermal stress. They should be considered at this point as strictly qualicative results and not appropriate for detailed design due to lack of approptlate input data. However, they suggest which parameters need to be measured accurately. 


\section{2,11 :LCHANICAL PROPERTIES OF IHTACT ROCK}

This section describes the mechanical properties (rock strength, Young's modulus, and Poisson's ratiol of basalt. Rather little infurmation is available for these properties whether for intact rock or the rock mass.

The available data, however, is for intact rock samples. As shown in Figure 2-15, the rocks which are classified as basalts have a very wide range of compressive strengths and moduli and, therefore, it is not possib?e to generalize or use a generic basis for any analysis.

Tables 2-7, 2-8, 2-9 and 2-10 are summary sheets compiled by the Office of Nuclear Waste Isolation, 1978. It was noted that the information base is rather small and that there was a wide variation in properties within the generic term "basalt." The modulus varies between 5 and $i 6 \times 10^{6}$ psi (34.5-110GPa), for example. More detailed values for Dresser basalt are given in Tables 2-11 and 2-12 for tests conducted under atmospheric temperature and pressure conditions. As might be expected, the strength increases with the confining pressure. Engineering data for basalts tested from Amchitka Island are given in Tables 2-13 and 2-14. It is noted that these data are for dry rocks. Figure 2-16 shows the significant effect of moisture on the compressive and tensile 


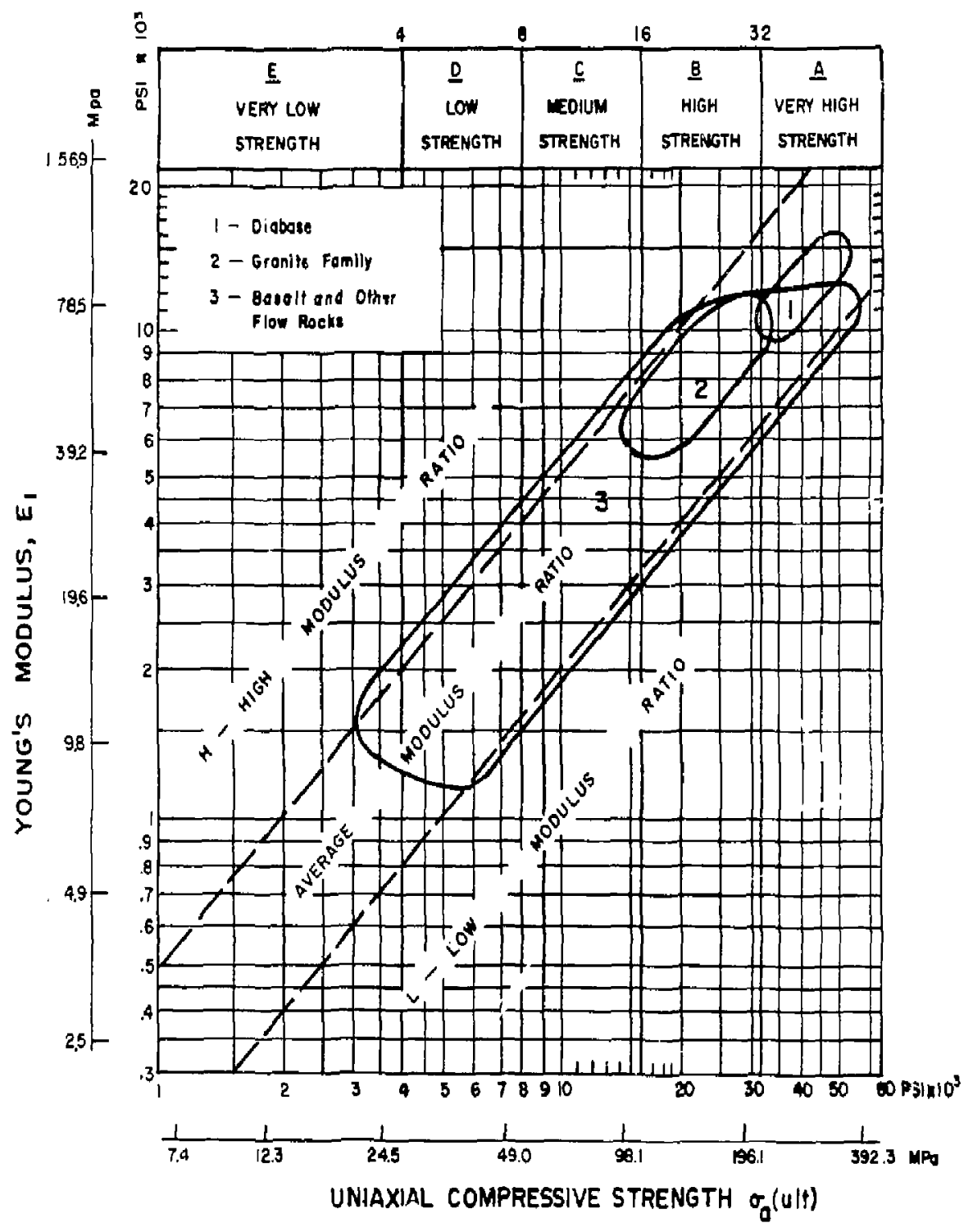

FIGURE 2-15 Engineering classification for intact rocksumary plot irneous rocks, 176 opectmens

Source: Deere et al, 1:66. 
TABLE 2-7 Intact properties of Dresser basalt,

\section{BASIC PARAMETERS}

Type of Property

Index

tress-strain

Thermal

Hydrological

Horizontal Permeability

Vertical Permeability
MKS Units

$3010.2 \mathrm{~kg} / \mathrm{m}^{3}$

Natural moisture

content (intact)

$--\%$

Porosity (rock mass)

$0.19 \%$

Young's Modulus

$93.1 \mathrm{GPa}$

Poisson's Ratio

0.264

Bulk Modulus

Shear Modulus

$4.15 \mathrm{GPa}$

Cohesion 10.34-24.14

Friction Angle MPa range

Uniaxial Compressive

Strength

$440.7 \mathrm{MPa}$

Tensile Strength

22. $1 \mathrm{MPa}$

Coefficient of Linear

Thermal Expansion

$8.9 \times 10^{-7} /{ }^{\circ} \mathrm{C}$

Heat Capacity

$.95 \mathrm{~J} / \mathrm{g} /{ }^{\circ} \mathrm{C}$

Thermal Conductivity

1.30 w/Ho K

SOURCE: Office of Nuclear Waste Isolation, 1978 
Table 2-8 Intact properties of Amchitka Island dense basalt. BASIC PARAMETERS

Type of Property

Index

Stress-strain

Strength

Thermal

Hydrological
Parameter

Unit Welght

Natural molsture

content (intact)

Porosity (rock mass)

Young's Modulus

Poisson's Ratio

Bulk Modulus

Shear Modulus

Cohesion 10.34-24.14

Friction Angle MPa range

Uniaxial Compressive

Strength

Tensile Strength

Coefficient of Lineas

Therual Expansion

Heat Capacity

Thermal Conductivity

Peroeability
MKS Units

$2729.8 \mathrm{~kg} / \mathrm{m}^{3}$

$--\%$

$2.8 \%$

$61.16 \mathrm{~Pa}$

0.19

$32,8 \mathrm{GPa}$

$25.7 \mathrm{Ga}$

60 degrees

250MPa

$15.5 \mathrm{MPa}$

$8.90 \times 10^{-7} /{ }^{\circ} \mathrm{C}$

$.96 \mathrm{~J} / \mathrm{g} /{ }^{\circ} \mathrm{C}$

$1.30 \mathrm{w} / \mathrm{m}^{\circ} \mathrm{K}$

$.0205 \mathrm{~m} / \mathrm{day}$

SOURCE: Office of Nuclear Waste Isolation, 1978 
TABLE 2-9 Intact properties of Nevada test site basalt.

\section{BASIC PARANETERS}

Type of Property

Index

Stress-strain

Strength

Thermal

Hydrological
Parameter

Unit Weight

Natural moisture

content (intact)

Porosity (rock mass)

Young's Modulus

Poisson's Rat1o

Bulk Modulus

Shear Modulus

Cohesion 10.34-24.14

Eriction Angle MPa range

Uniaxial Compressive

Strength

Tensile Strength

Coefficient of Linear

Thermal Expansion

Heat Capacity

Thermal Conductivity

Horizontal Permeability

Vertical Permeability
MKS Units

$2689.8 \mathrm{~kg} / \mathrm{m}^{3}$

$4.6 \%$

$34.9 \mathrm{GPa}$

$0.32=$
$148 \mathrm{MPa}$

13. $1 \mathrm{MPa}$ 
TABLE 2-10 Intact properties of Columbia River group basalt.

\section{BASIC PARAMETERS}

Type of Property

Index

Stress-strain

Strength

Thermal

Hydrological
Parameter

Unit Weight

Natural moisture

content (intact)

Porosity (rock mass)

Young's Modulus

Poisson's Ratio

Bulk Modulus

Shear Modulus

\begin{tabular}{|c|c|}
\hline $\begin{array}{l}\text { Cohesion } 10.34-24.14 \\
\text { Friction Angle } \mathrm{MPa} \text { range }\end{array}$ & $\begin{array}{l}14.5-38.6 \mathrm{MPa} \\
45^{\circ}-60^{\circ}\end{array}$ \\
\hline Uniaxial Compressive & \\
\hline Strength & $193.1-400.0 \mathrm{MPa}$ \\
\hline Tersile Strength & $12.41-24.14 \mathrm{MP}$ \\
\hline
\end{tabular}

Coefficient of Linear

Therma: Expansion

Heat Capacity

Themal Conductivity

Permeability
MKS Uaits

$2403-3085 \mathrm{~kg} / \mathrm{m}^{3}$

$55.2-110 G P a$

$0.22-0.30$

$$
\begin{aligned}
& 1.67 \times 10^{-6}{ }^{\circ} \mathrm{C}^{-1} \\
& .72-.96 \mathrm{~J} / \mathrm{s} /{ }^{0} \mathrm{C} \\
& 1.00-1.35 \mathrm{w} / \mathrm{m}^{\circ} \mathrm{K} \\
& 9.67 \times 10^{-6}-3.87 \times 10^{-5} \\
& \mu \mathrm{m} / \mathrm{sec}
\end{aligned}
$$

SOLRCE: Office of Nuclear Waste Isolation, 1978 
TARLF: 2-11 Dresset Basalt test results

\section{Property}

(Kreck et a1, 1964 )

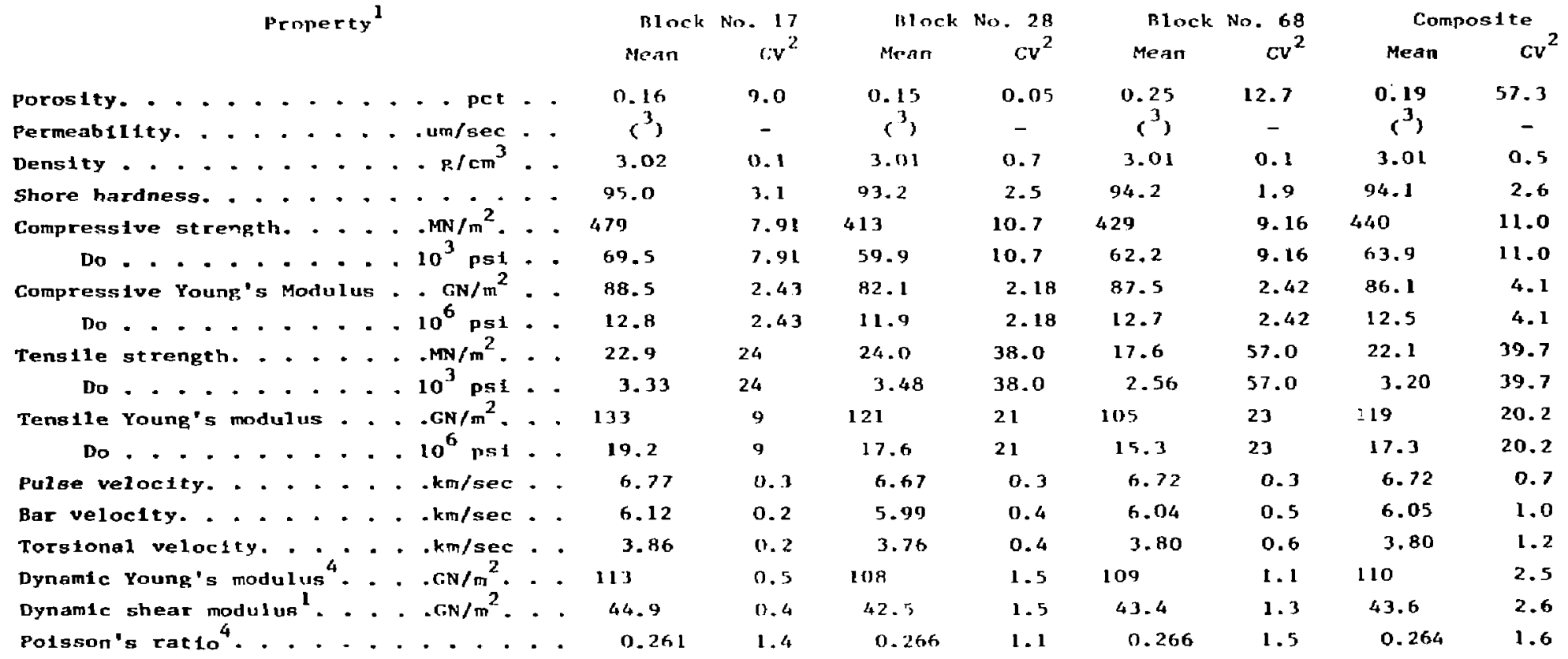

Ispecimen prepared with the long axts perpendicular to the top face (along 7-axis)

${ }^{2}$ coeffictent of variation, percent.

3 Less than $1 \times 10^{-4} \mathrm{um} / \mathrm{sec}$.

${ }^{4}$ Calculation is based on the assumption of tsatropy. 
TABLE 2-12 Properties of Dresser basalt (Morrell and Larson, 1974) and (Avco, 1972)

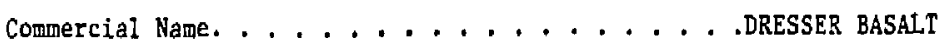

Rock Type. . . . . . . . . . . . . Basalt

Locality . . . . . . . . . . . . Dresser, Wisconsin

Compressive Strength, MPa. . . . . . . . . 439

Tensile Strength, MPa. . . . . . . . . . 14

Shore Hardness, Scleroscope units. ........ 85.8

Apparent Density, $\mathrm{g} / \mathrm{cm}^{3} \ldots \ldots \ldots . . \ldots . . \ldots 29$

Static Young's Moduius, GPa. . . . . . . . . 98.3

Longitudinal velacity, mps .......... 6,669

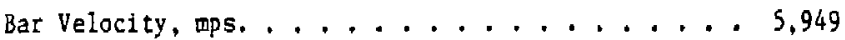

Shear Velocity, mps. ........ 3,739

Dynamic Young's Modulus, GPa . . . . . . . . 107.2

Poisson's Ratio. ............... 0.2725

Shear Modulus, GPa . . . . . . . . . 42.3

Tensile Fracture Stress, $n / m^{2} \ldots \ldots \ldots 1.45 \times 10^{7}$

Thermal Conductivity Coefficient A ...... $1.45 \times 10^{-5}$

Thermal Conductivity Coefficient B ......... $\quad-.15$

Coeffictent of Thermal Expansion, ${ }^{\circ} \mathrm{C}^{-1} \ldots \ldots 3 \times 10^{-6}$ 
TABLE 2-13 Average engineering properties of water saturated Amchitka Island rocks by major rock types in the recognized formations (Shatp, 1972)

\begin{tabular}{|c|c|c|c|c|c|}
\hline (2) & (3) & (4) & (5) & (6) & (7) \\
\hline LEGEND & INCREASED & COMPRESSIVE & TENSILE & YOUNG'S & VIOLENCE \\
\hline (See & MOISTURE & STRENGTH & STRENGTH & MODULUS & OF \\
\hline Notes) & (vol. pet.) & & & & \\
\hline \multicolumn{6}{|c|}{ HORNBLENDE PYROXENE ANDESITE - TCPI-1 } \\
\hline AVG: & 3.5 & 108.69 & 10.61 & 22.90 & 3.1 \\
\hline MAX: & 15.6 & 198.25 & 17.57 & 56.21 & 8 \\
\hline MIN: & 1,2 & 9.34 & .66 & 2.00 & 1 \\
\hline N: & 26 & .14 & .06 & 137.93 & 23 \\
\hline S: & 4.0 & 62.05 & 5.03 & 14.76 & 2.0 \\
\hline V: & 115.9 & .40 & .33 & 445.51 & 58.3 \\
\hline \multicolumn{6}{|c|}{ CHITKA POINT FORMATION: DENSE FLOW BRECCIA - TCP1-11 } \\
\hline AVG: & 6.4 & 73.95 & 11.86 & 17.79 & 2.8 \\
\hline MAX: & 10.4 & 104.72 & 18.37 & 31.72 & 4 \\
\hline MIN: & 2.4 & 47.23 & 5,35 & 10.21 & 2 \\
\hline N: & 10 & .03 & .01 & 34.48 & 5 \\
\hline S: & 2.9 & 22.86 & 9.20 & 8.34 & 0.8 \\
\hline V: & 46.3 & .21 & .54 & 324.14 & 29.9 \\
\hline \multicolumn{6}{|c|}{ HORNBLENDE ANDESITE BRECCIA - TCp -1} \\
\hline AVG: & 7.7 & 48.42 & 3.01 & 14.62 & 2.0 \\
\hline MAX: & 17.9 & 117.92 & 6.01 & 25.24 & 3 \\
\hline MIN: & 3.2 & 13.32 & 1.47 & 4.00 & 1 \\
\hline N: & 9 & .06 & .02 & 55,17 & 7 \\
\hline S: & 4.5 & 32.57 & 2.59 & 8.21 & 1.0 \\
\hline V: & 57.9 & .46 & .59 & 388.27 & 50.2 \\
\hline \multicolumn{6}{|c|}{ CHITKA POINT FORMATION: TUEF BRECCIA $\cdot$ ICP-11 } \\
\hline AVG: & 14.6 & 49.83 & 3.06 & 9.03 & 2.8 \\
\hline MAX: & 31.4 & 116.05 & 2.12 & 20.97 & 7 \\
\hline MIN: & 6.7 & 4.49 & .70 & 1.45 & 1 \\
\hline N: & 26 & .15 & .06 & 151.72 & 23 \\
\hline S: & 7.3 & 32.42 & 1.74 & 5.59 & 1.6 \\
\hline V: & 50.1 & .45 & .39 & 424.13 & 57.2 \\
\hline \multicolumn{6}{|c|}{ BANJO POINT FORMATION: BRECCIA - TCP } \\
\hline AVG: & 16.6 & 34.44 & 6.49 & 6.76 & 1.6 \\
\hline MAX: & 29.2 & 157.96 & 17.11 & 19.03 & 4 \\
\hline MIN: & 3.7 & 9.33 & .92 & 1.79 & 1 \\
\hline N: & 18 & .08 & .05 & 68.97 & 11 \\
\hline S: & 7.2 & 42.58 & 7.38 & 5.66 & 1.1 \\
\hline V: & 43.2 & .85 & .78 & 580,00 & 68.5 \\
\hline \multicolumn{6}{|c|}{ DENSE BASALTS - Tb } \\
\hline AVG: & 2.8 & 123.21 & 15.17 & 30.14 & 5.1 \\
\hline MAX: & 7.7 & 196.72 & 17.54 & 77.31 & 9 \\
\hline MIN: & 1.1 & 75.48 & 12.79 & 14.34 & 3 \\
\hline N: & 10 & .07 & .01 & 68.97 & 10 \\
\hline S: & 2.2 & 38.22 & 3.36 & 18.76 & .0 \\
\hline
\end{tabular}


TABLE 2-13 (Continued)

(2)

$\begin{array}{ll}\text { LEGEND } & \text { INCREASED } \\ \text { (See } & \text { MOISTURE } \\ \text { Notes) } & \text { (vol, pct.) }\end{array}$
(4)

$\begin{array}{cc}\text { COMPRESSIVE } & \text { TENSILE } \\ \text { STRENGTH } & \text { STRENGTH } \\ \text { (MPa) } & \text { (MPa) }\end{array}$

(6)

YOUNG'S

MODULUS

(GPa)
(7) VIOLENCE

$0 \mathrm{~F}$

RUPTITE

AMCHITKA FORMATION: KIRILOF POINT GLASS: BRECCIAS - TAkb-1

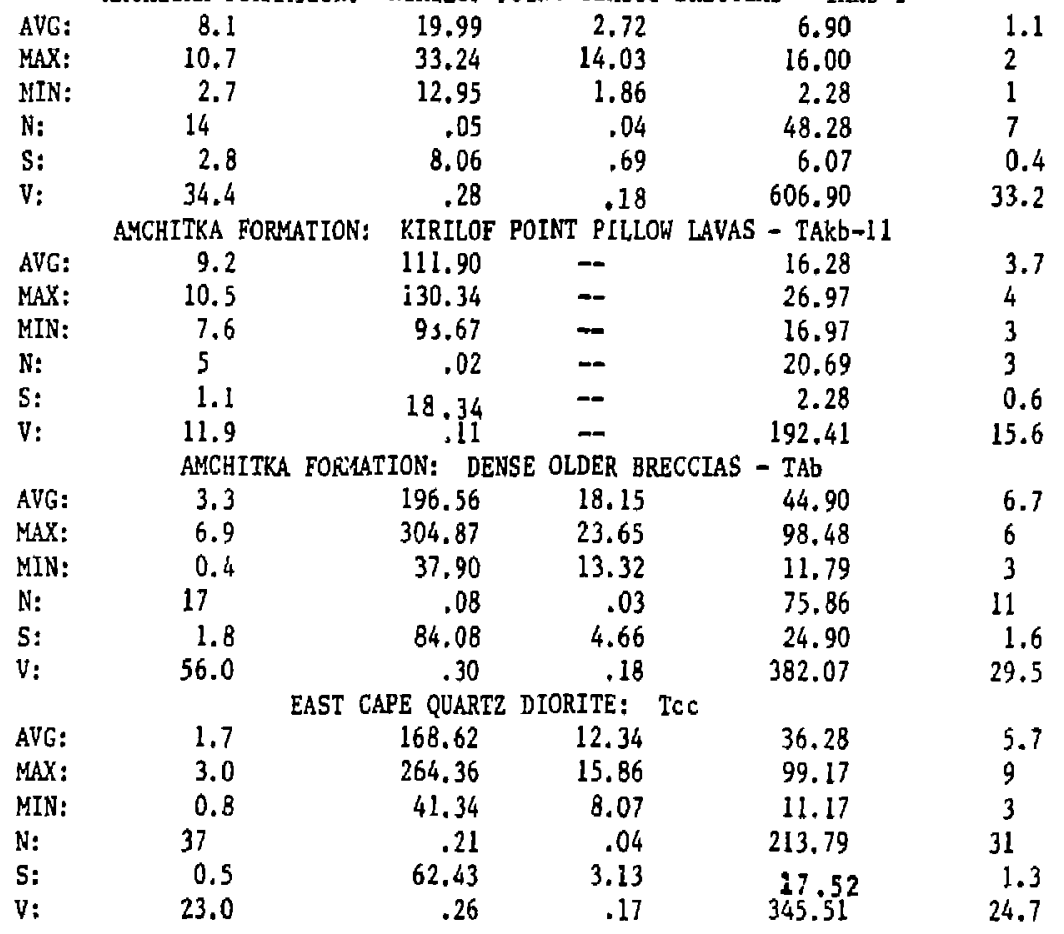

NOTES: The average (AVG), maximum (MAX), and minimum (MIN) values determined from the number (N) of specimens in each group, with the standard deviation ( $S$ ) and percentage variation (V), are given in acsending order for each group property across the table. Values in Colunn 5 represent the increased molsture In the saturated state (afte- 7 days submersion) over that air dried (14 days) in volume percent. 


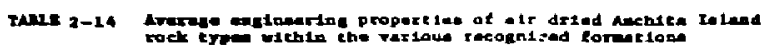

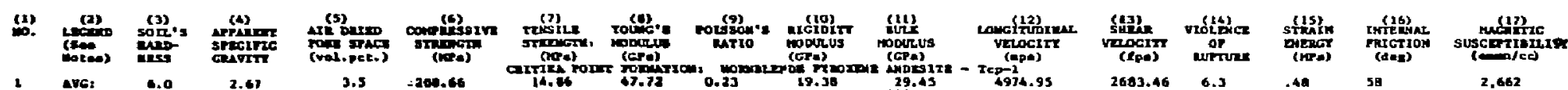

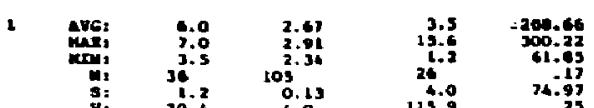

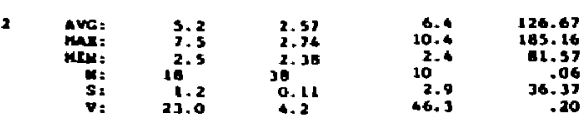

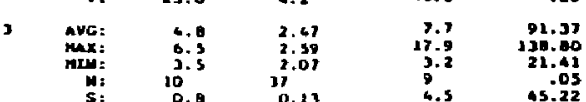

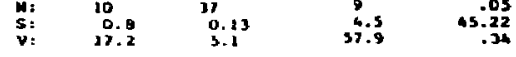

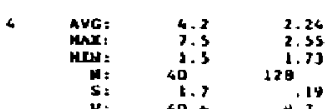

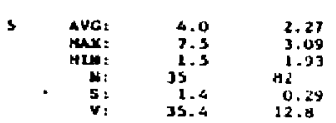

$\begin{array}{rr}14.6 & 92.10 \\ 31.4 & 156.00 \\ 6.7 & 17.05 \\ 26.03 & 48.17 \\ 50.3 & 48\end{array}$

$\begin{array}{rr}16.6 & 218.83 \\ 39.2 & 339.49 \\ 3.7 & 9.18 \\ 18 & .10 \\ 7.2 & 125.96\end{array}$
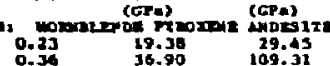

2503.46 0.3

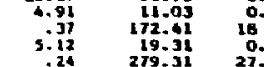

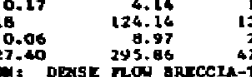

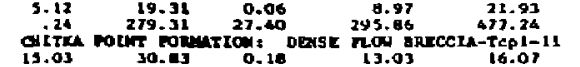

21

curtion 20.000

35.2470

10.35

4.15
2.49
.23

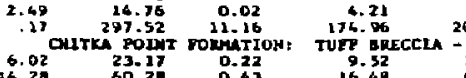

6.02
14.28
1.06
. .48
3.64

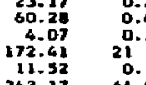

$\begin{array}{ccc}.42 & 363.17 & 44.05 \\ 6.82 & 29.38 & 0.22 \\ 29.56 & 81.03 & 0.37\end{array}$

29.54
1.43
7.00
7.00

96.55
28.76
395.07
7.92
1132.16
7.07

2298.50 5.s

$\begin{array}{rr}2298.50 & 5.3 \\ 2910.54 & 9 \\ 1946.50 & 1 \\ 1.32 & 33 \\ 184.05 & 2.6\end{array}$

$2734.78 \quad 3.7$

$\begin{array}{rr}2335.73 & 8 \\ 2457.90 & 1 \\ 501 & 29 \\ 502.92 & 2.4 \\ 5.58 & 64.1\end{array}$

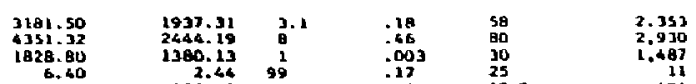

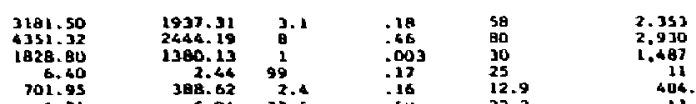

$\begin{array}{rrr}3218.69 & 2153.85 & 2.3 \\ 5651.60 & 1141.00 & 8 \\ 1277.14 & 1234.56 & 1 \\ 8.60 & 12.22 & 68 \\ 1235.47 & 818.30 & 2.4 \\ 11.89 & 11.58 & 96.8\end{array}$

$\begin{array}{rr}.49 & 58 \\ .93 & 85 \\ .15 & 20 \\ .17 & 25 \\ .22 & 15\end{array}$

3.;062

595.0

$\begin{array}{rrr}.10 & 62 & 1.904 \\ .56 & 90 & 3.274 \\ .15 & 56 & 947\end{array}$

$\begin{array}{rrr}05 & 8 & \\ .14 & 8.5 & 1,102.8 \\ .32 & 10.5 & 32.8\end{array}$

$\begin{array}{lll}.15 & 61 & 1,953 \\ .26 & 32 & 2,820\end{array}$

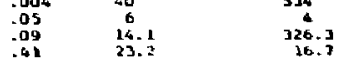

404.2 


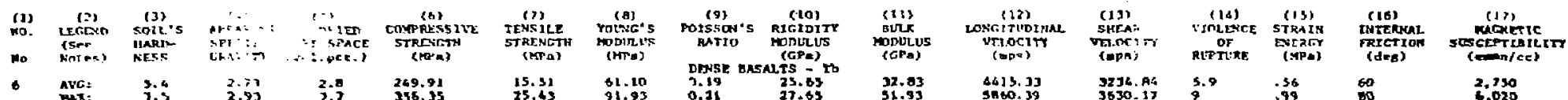

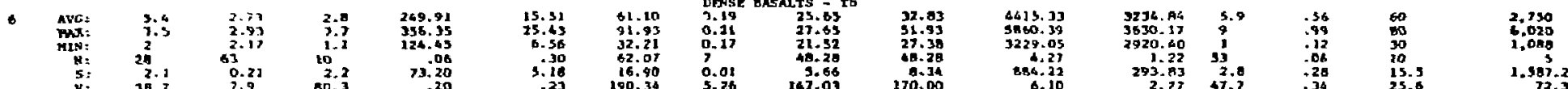
$\begin{array}{lllll}\text { N: } & 29 . & 63 & 10 & \\ 5: & 2.1 & 0.23 & 2.2 & 73.20 \\ \text { v: } & 38.7 & 7.9 & 80.3 & .20\end{array}$

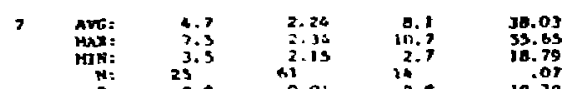

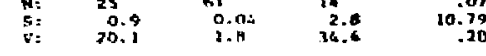

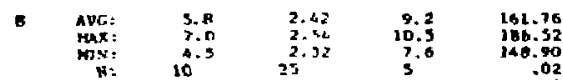

$\begin{array}{rrrr}103 & 23.07 & 3.1 & 21.02 \\ 22.9 & 0.0 & 11.9 & .09\end{array}$

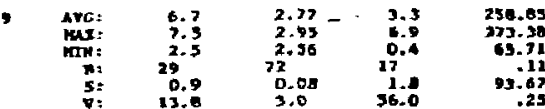

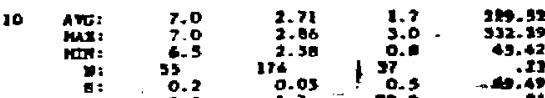

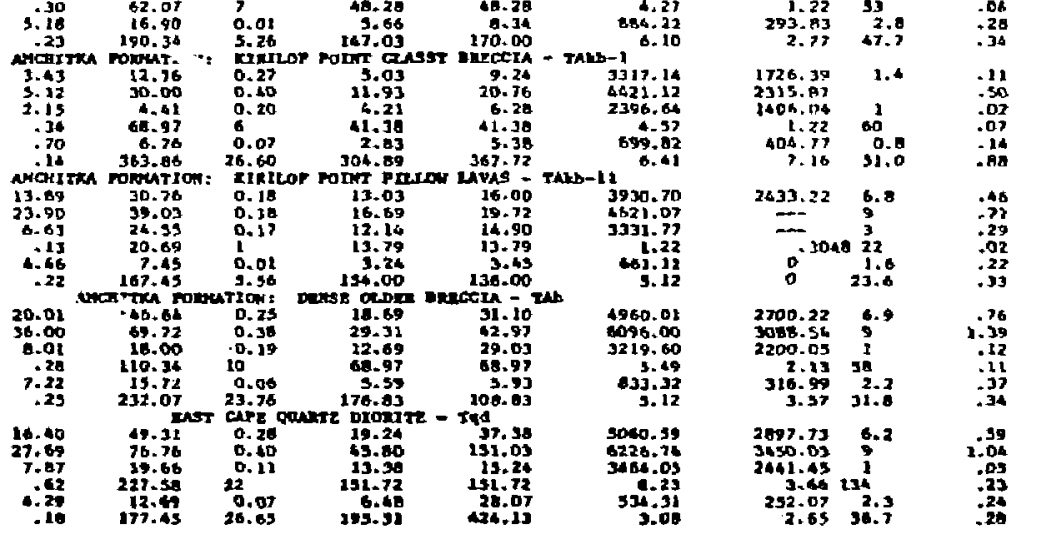

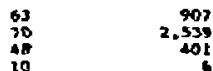

10.78

$\begin{array}{rrr}60 \\ 70 \\ 40\end{array} \quad 3 . \quad \begin{array}{r}2.976 \\ 3: 076 \\ 3\end{array}$

${ }_{20.3}^{20.3}=$

$67 \quad 3.169$

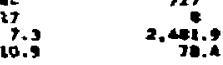

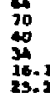

(5T)

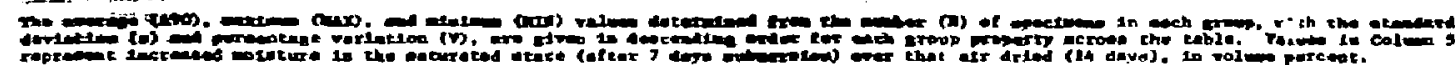




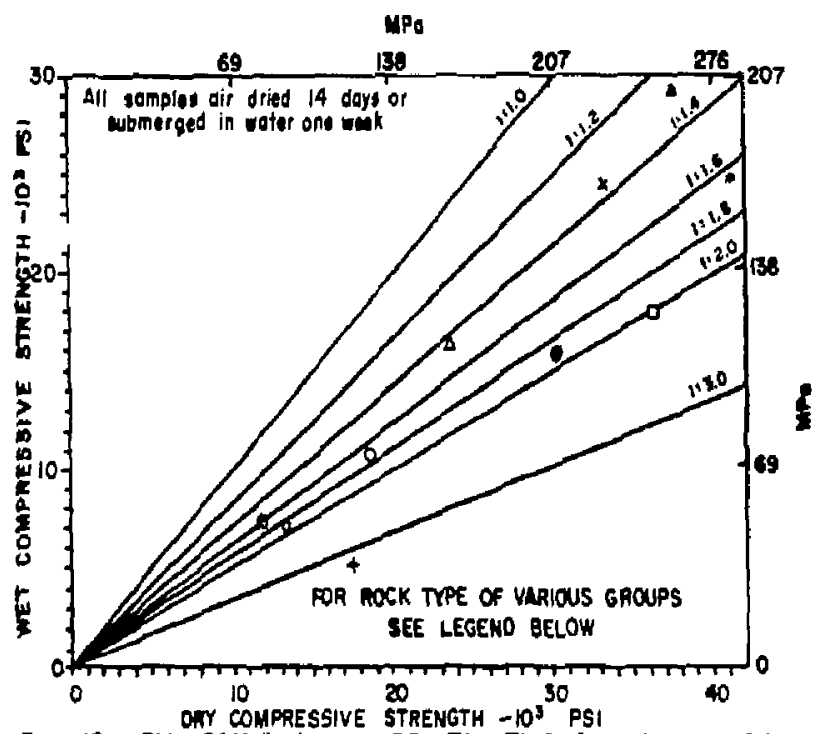

WET VS. DRY COMPRESSIVE STRENGTHS OF LOCAL ROCK

aVERAge VALUES OF MANOR FORMATIOHAL MO hithOLOGIC gROUPS

- FtDit $n-D$ anor Dite

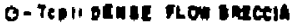

Q- Top' anderite unecala

Ditc, tuff Defecia
LFENAT

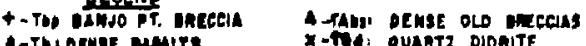

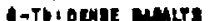

- Thor clasir entcelas
Tha nohiptes

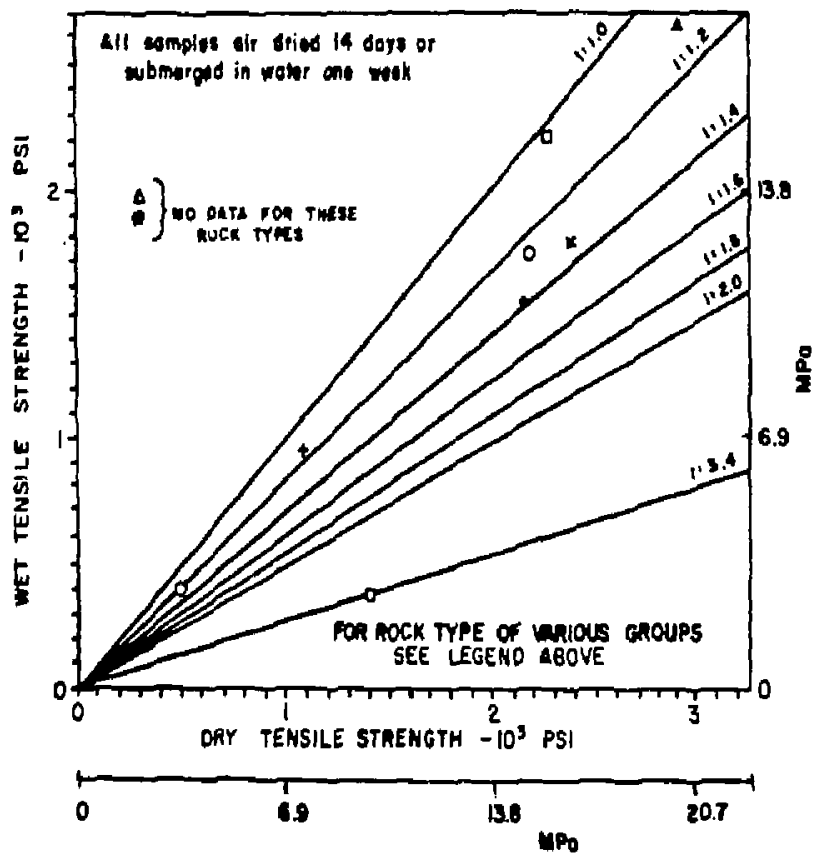

IIGUR 2-16 Wet Vo, dry tenstle stengths of local rock average values of anjer formatonal and lithologic groups. Source: Sherp. 1972. 
strengths of Amchitka basalt. Data for basalt tested from the Nevada test site are shown in Figures 2-17 to 2-19. Figure 2-18 shows the relationship between strength and confining pressure for basaltic rocks of different porosities. A very high dependence of strength on the porosity is observed. Figure 2-19 shows variation of Poisson's ratio with confining pressure for NTS basalt. Notice that for a relatively large change in confining pressure, Poisjon's ratio varies rather little. As suggested sarlier from the scoping studies, this variation is probably not significant. Values for the strength for samples from the Hanford reservation are shown in Table 2-15. Of particular interest are the results from rock zone RM4 which illustrate the large effect of jointing on strength. Tables 2-16 and 2-17 and Figures 2-20 and 2-21 are for physical properties of Columbia Plateau basalts. As seen in Figures 2-20 and 2-21 there are very large variations in strength with porosity and density. Both of these values would depend very much on the position within the flow. The same type of behavior for test site basalt is shown in Figure 2-22. Because of this great variation, one nust be very careful when attempting to determine and assign property values. Tables $2-18$ and 2-19 summarize some values for elastic and strength properties of basaltic rock samples (Agapito et al, 1977, Rodriquez, 1970). 

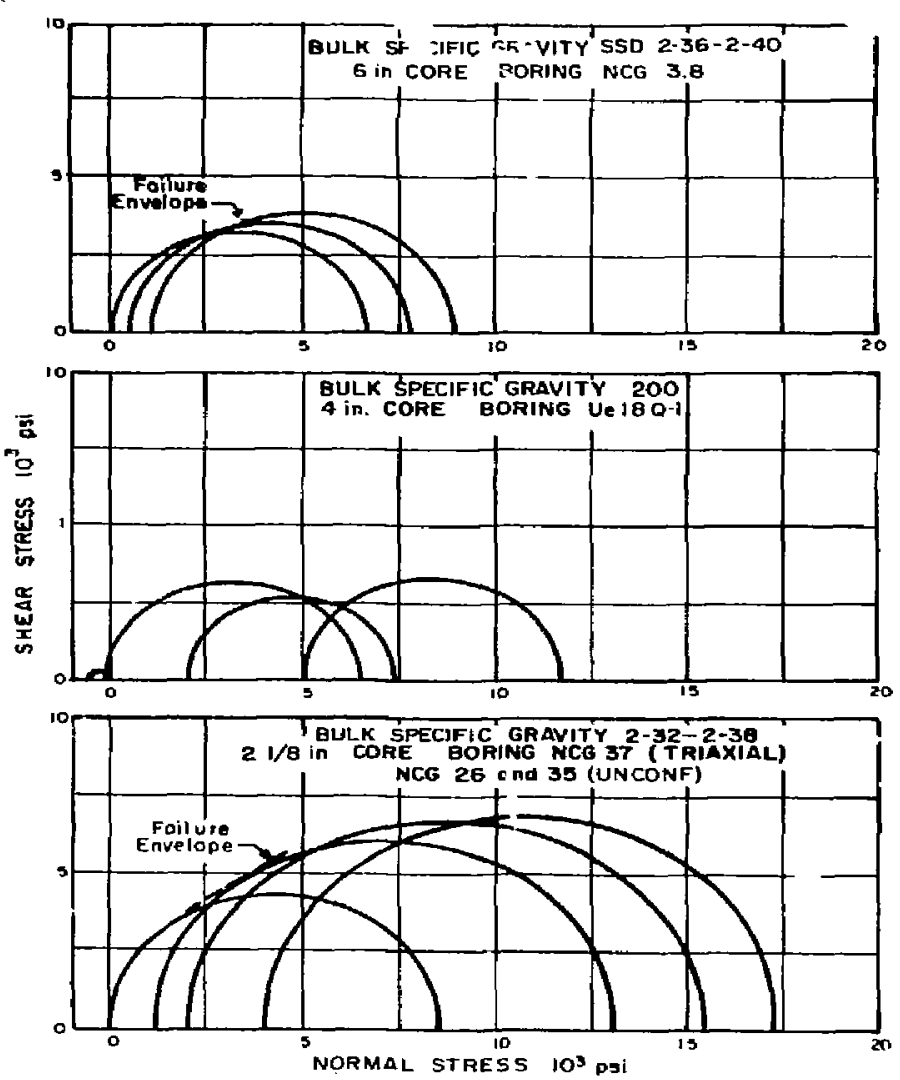

MOHR CIRCLES and FAILURE ENVELOPES

FOR HIGHLY VESICULAR BASALT

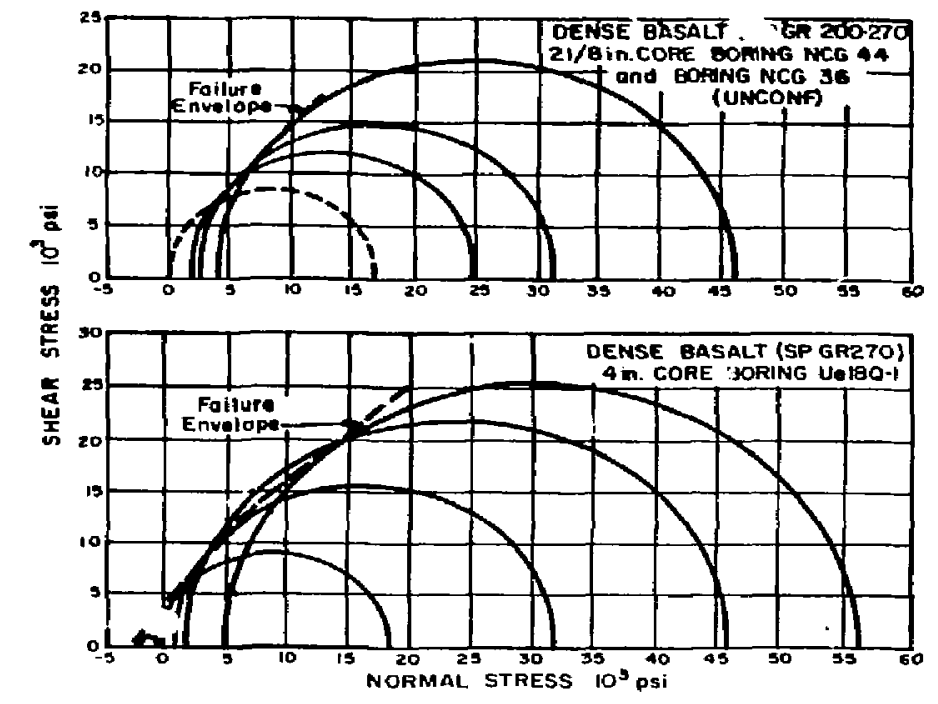

MOMR CIRCLES and FAILURE ENVELOPES FOR DENSE BASALT

EIGUir 2-17 Mohr circles for dense and vesicular bagalt Source: Lutton. 1968 . 


\section{MROSITY}

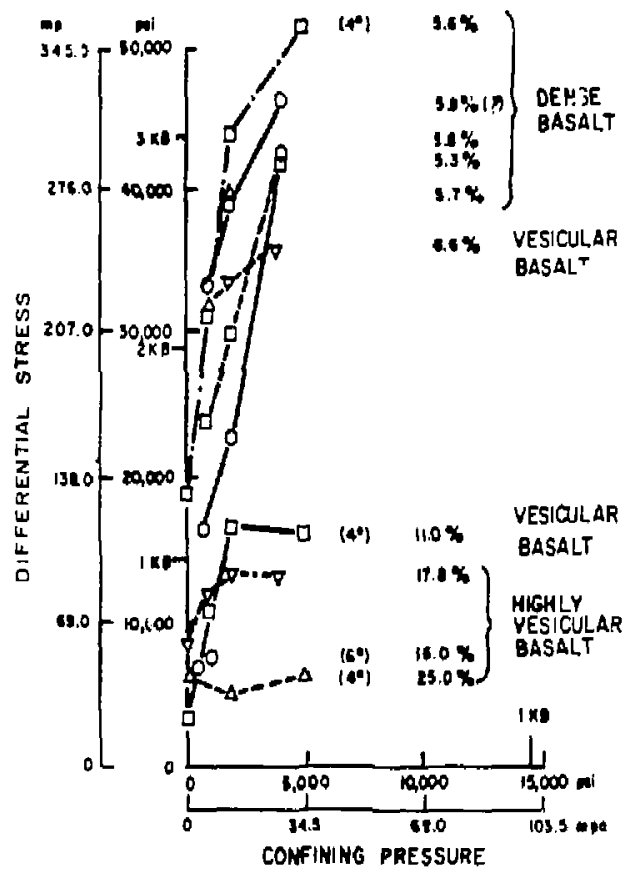

FIGURE 2-18 Relationship between strength and confined pressure for basaltic rocks of different porosity. Source: Lutton, 1968. 


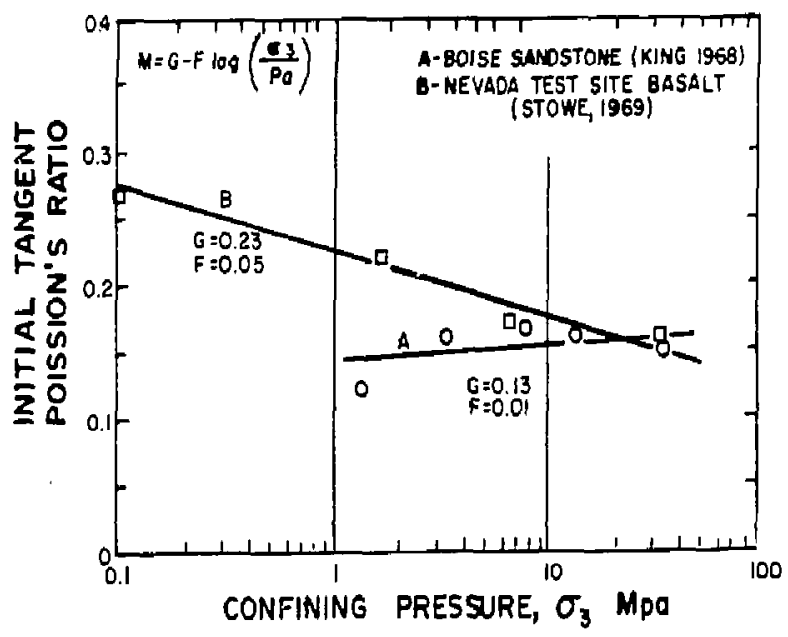

FIGURE 2-19 Variation of injitial tangent Poisson's ratio with confining pressure

Source: Stowe, 1969. 
TABLE 2-15 Summary of triaxial compression strength tests on core from the Hanford Reservation, DDH-1 testo by Teledyne Terrametrics

(Agapito, Hardy and St. Laurent, 2977)

Rock Zone

RM 1

RM 2 (Solid)

RM 1 (With Slip Planes)

$\begin{array}{cc}\text { Confining } & \text { Average } \\ \text { Pressure } & \text { Strength } \\ \mathrm{MPa} & \mathrm{MPa}\end{array}$

3

0

212

287

305

350

7.0

14.0

21.0

400

0

266

7.0

361

14.0

21.0

28.0

481

562

638

$\begin{array}{rr}0 & 143 \\ 7.0 & 179 \\ 14.0 & 252 \\ 21.0 & 331 \\ 28.0 & 390\end{array}$

RM 3 (Al1 Specimens Contained Yany Open Vugs and Pores)

0

69

7.0

93

14.0

21.0

28.0

145

172

152

RY 4 (Solid)

2

0

216

7.0

307

14.0

434

RM 4 (with Joints) 
TABLE 2-16 Summary of rock properties Bacon Siphon and Tunnel - second untr DH-lOD series sanples

Columbia Basin Project

Source: Agapito et al, 1977

\begin{tabular}{|c|c|c|c|c|c|}
\hline $\begin{array}{l}\text { Spec } \\
\text { DH }\end{array}$ & $\begin{array}{l}\text { 1men No. } \\
\text { Depth }\end{array}$ & Rock Type & $\begin{array}{l}\operatorname{Secant} 1 / \\
\text { Fiastictty } \\
\text { GPa }\end{array}$ & $\begin{array}{c}\text { Compressive } \\
\text { strength } \\
\text { Mla }\end{array}$ & $\begin{array}{c}\text { Fracture } 2 / \\
\text { Mode }\end{array}$ \\
\hline 100 & 88.3 & Masalt & 43 & 81 & $\begin{array}{l}\text { Across matrlx } \\
\text { and structure }\end{array}$ \\
\hline 100 & 101.9 & Basa1t & 53 & 98 & $\begin{array}{l}\text { Across matrix } \\
\text { and st ructure }\end{array}$ \\
\hline 101 & 120.9 & Basalt & 23 & 216 & $\begin{array}{l}\text { Across matrix } \\
\text { and structure }\end{array}$ \\
\hline 100 & 148.7 & Basalt & 22 & 83 & $\begin{array}{l}\text { Across matrix } \\
\text { and st ructure }\end{array}$ \\
\hline 100 & 152.8 & Basa1t & 22 & 137 & $\begin{array}{l}\text { Across matrix } \\
\text { and structure }\end{array}$ \\
\hline 100 & 181.5 & Basalt & 30 & 194 & $\begin{array}{l}\text { Acrosis mintrix } \\
\text { and structure }\end{array}$ \\
\hline
\end{tabular}

Ahsorption, Percent

by Weight

Spectfic

Prtrographlc

Tahoratory No.
3.9
2.57
P-8521

3. 7

2.61

$p-8528$

2.1

2.74

P-8529

3.9

2.58

$P-8530$

3.7

2.62

P-8531

2.5

2.65

P-R5,32

Notes:

1/F. Is pivon at flrst cycle of loading, 7MPa strisst

z/pertains to somples falled in compression tosts. 
TABLE 2-17 Suminary of rock properties Bacon Siphon and Tunnel - second unit DH - 2C0 series samples

Columbia Basin Project

Source: Apapito eta1, 1977

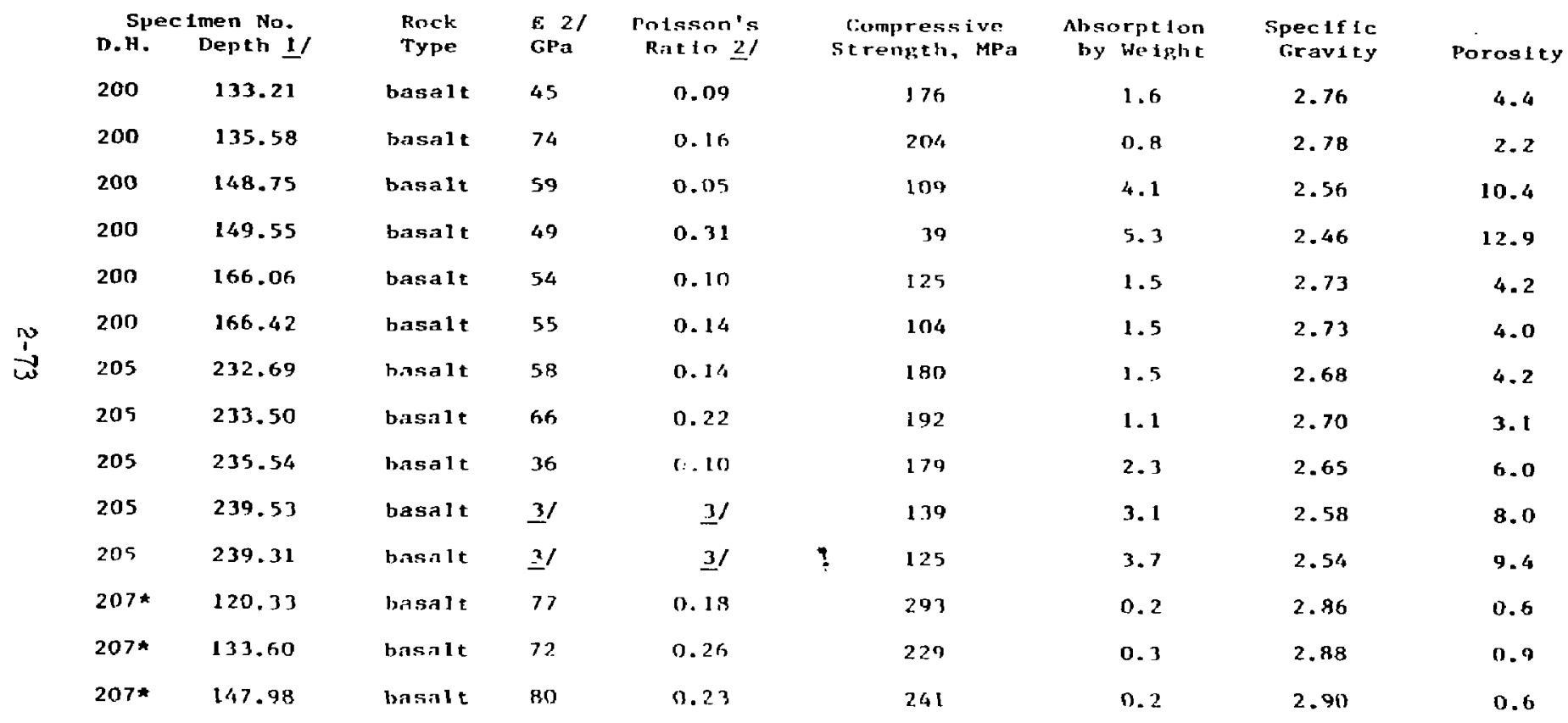

Notes:

1/Depth, In fret, Is measured to the conter of the tast spretmen.

T/Fiagtelty and Polsson's Ratio are pluen for fiest cycle loading at 7Mra.

3/No elastlelty run on these test apectmens due to larpo vesteles.

*No metropraplif analyals requested for brill llol. 207. 


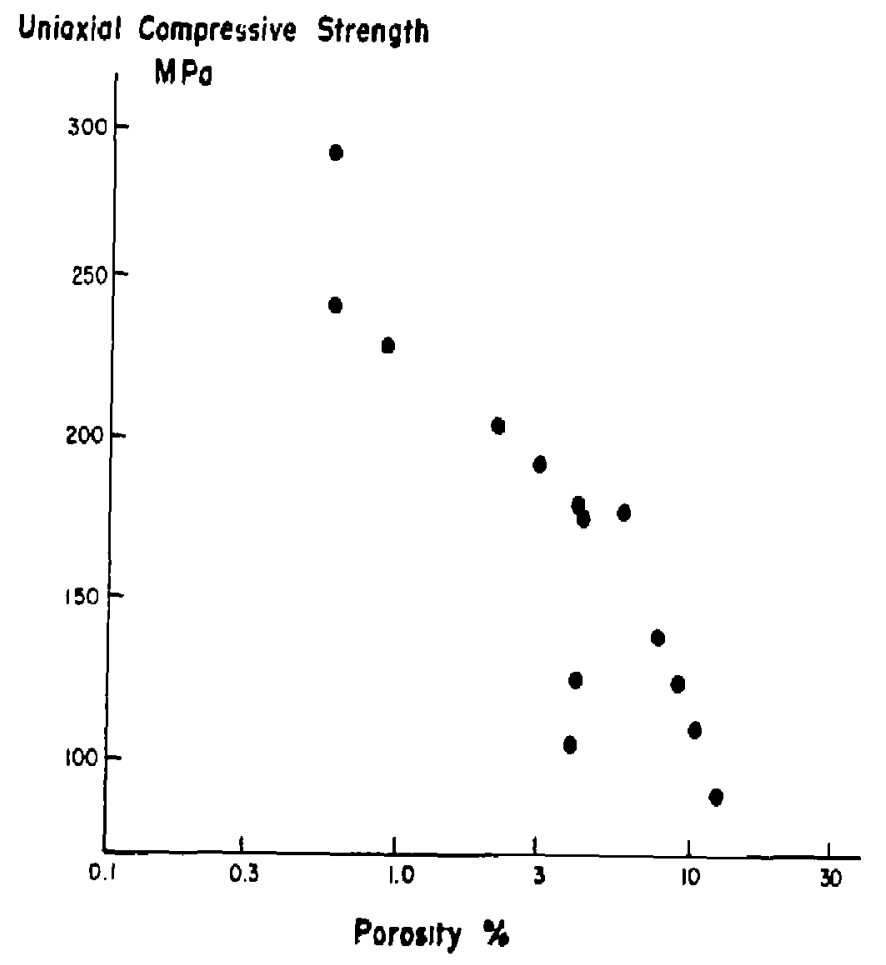

FIGURE 2-20 Compressive strength versus porosity Columbia plateau basalt Source: Agapito et al, 1977. 


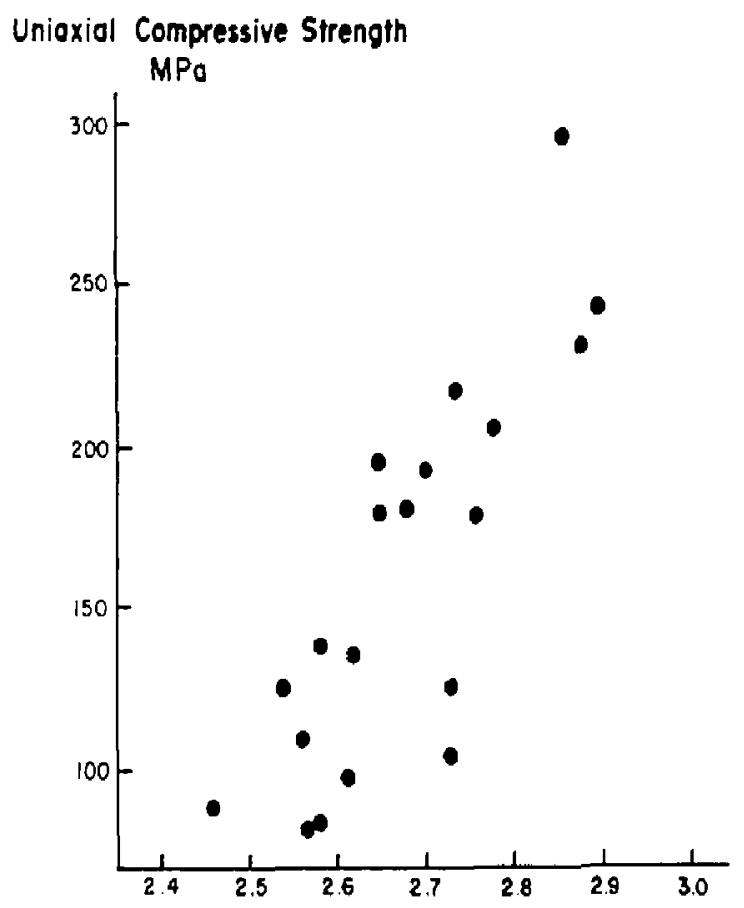

Specific Grovity

FIGURE 2-21 Compressive ctrength versus spectfic gravity Columbia Plateau basalt

Source: Agapito et al, 1977. 


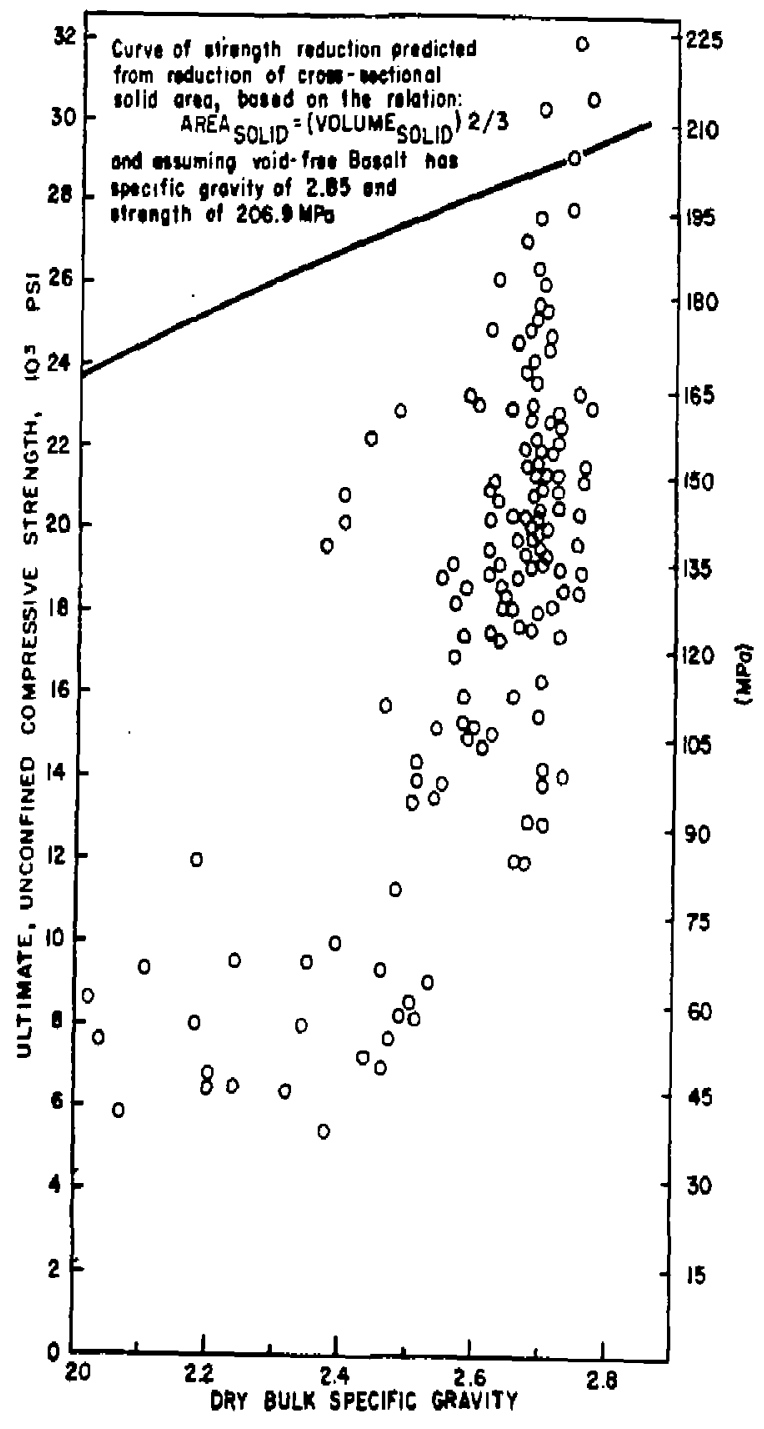

FIGURE 2-22 Relation of compressive strengthg and opecifle gravity.

Source: Sendia, 1962. 
TABLE $2-18$ Strength data on basalts

$\begin{array}{lcccc}\text { Rock Type } & \begin{array}{c}\text { Crushing } \\ \text { Strength } \\ \text { MPa }\end{array} & \begin{array}{c}\text { Cohesive } \\ \text { Strength } \\ \text { MPa }\end{array} & \text { Tan } 0 & \text { Reference } \\ \text { Basalt, Miocene, Oregon } & 169 & 32 & 1.2 & 8 \\ \text { Basalt, Miocene, Oregon } & 219 & 44 & 1.1 & 8 \\ \text { Hyperstene, Andesite } & 133 & 29 & 1.0 & 8 \\ \text { Hyperstene, Andesite } & 129 & 28 & 1.0 & 8 \\ \text { Basalt, Dresser } & 440 & \text { NA } & \mathrm{Ni} & 11 \\ \text { Basalt, Dresser } & 363 & \text { NA } & \mathrm{NA} & 19 \\ \text { Basalt, Knippa } & 262 & \text { NA } & \mathrm{NA} & 17 \\ \text { Source: Agapito et al, } 1977 & & & \end{array}$


TABLE 2-19 Elastic Properties of Basaltic Rock

Rock Type

Basalt, Ostritz,Gemany

Basait, Champion Mine, Michigan

Basalt, Champion Mine, Michigan

Basalt, Dresser, Wisconsin

Diajase, Frederick

Dolerite, Karroo

Gabbro, Norites, Diabases

Source: Agapito et al, 1977

$\begin{array}{cc}\begin{array}{c}\text { Young 's } \\ \text { Modulus } \\ \text { GPa }\end{array} & \begin{array}{c}\text { Poisson's } \\ \text { Ratio }\end{array} \\ 111.5 & \text { NA } \\ 61 & \mathrm{NA} \\ 85 & \mathrm{Ni} \\ 83.5 & 0.25 \\ 99 & \mathrm{Ni} \\ 86 & \therefore \mathrm{i} \\ 78-99 & 0.11-0.31\end{array}$

$73-99-0.11-0.31$ 
In sumary, the amount of data presently available regarding the mechanical properties of basalt is sparse. Available data from tests would suggest a high variability of compressive strength and modulus, with a lesser variation of Poisson's ratio. All vary with porosity and density. 


\subsection{THERYAL PROPERTIES}

Data concerning thermal properties of the rock are required for the calculation of thermal distributions around the excavation due to the introduction of the waste. There are a rumber of numerical techniques which can be used to calculate such thermal distributions. In general, they require as input the density, specific heat, thermal conductivity, and/or the thermal diffusivity of the basalt surrounding the caverns. These induced thermal fields are superimposed upon the geothermal gradient at the point of interest. Such a geothermal gradient from a hole at the Hanford facility is shown in Figure 2-23.

A knowledge of the density is required, since it controls the initial stress gradient and is needed to estimate thermal diffusivity. Table 2-20 sumnarizes the values obtained for the density of some asalts. Thaie is a considerable variation in density, as one might expect from the characteristics of basalt, and the tabulated values should not be used without extreme caution.

A number of tests have been performed to determine thermal constants for basalt as a function of temperature. Thermal properties for Hanford basalt are shown as a function of temperature in Tables $2-21$ and 2-22. Values fo- thermal 
TEMPERATURE $\left({ }^{\circ}\right)$

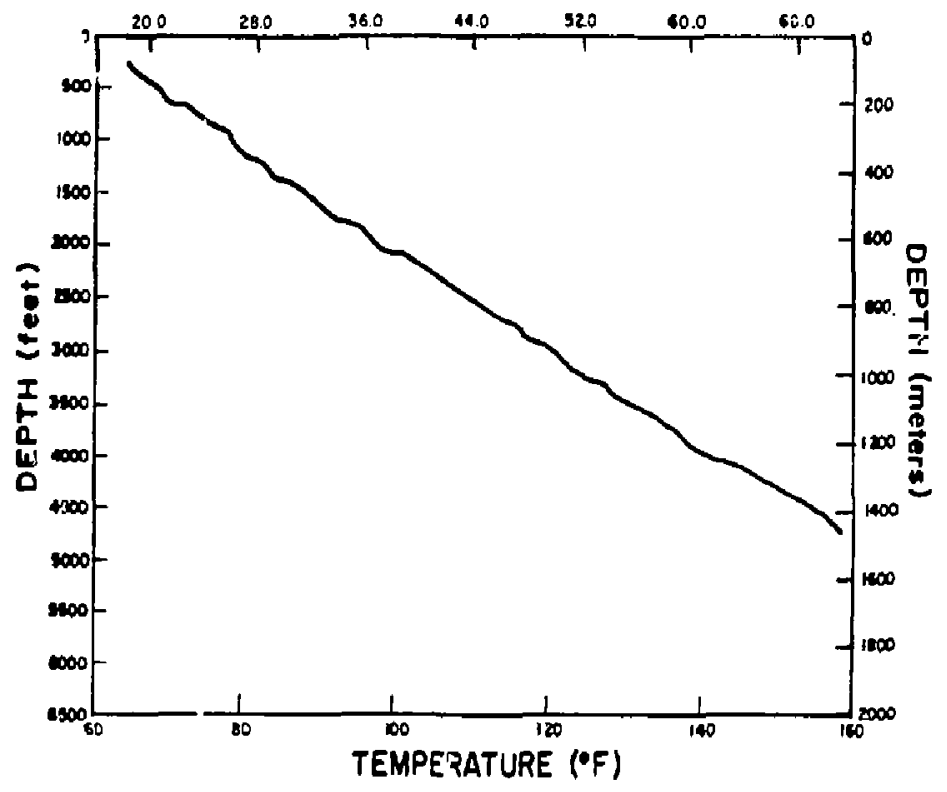

FICURE 2-23 Subsurface cemperature as a function of depth in $D C-1$ drill hole (geothermal gradient)

Source: Atlancic Richfield Hanford, 1976, v 1. 
TABLE 2-20 Density of some basalts.

$\begin{array}{lc}\text { ROCK TYPE } & \text { DENSITY }\left(\mathrm{g} / \mathrm{cm}^{3}\right) \\ \text { Basa! } & 2.4-3.1 \\ \text { Basalt } & 2.9 \\ \text { Average of General Basalt } & 2.8-2.9 \\ \text { Basalt } & 2.8 \\ \text { Gabbros, Norites, Diabase } & 3.0 \\ \text { Basalt, Dresser } & 3.02\end{array}$

SOURCE: Agapito et al, 1977 
TABLE 2-21 Thermal propertles of basalt

as function of temperature

(Atlant1c Richfield Hanford Co., 1977)

Sample 1005 Depth $=306$ m $(1005 \mathrm{ft})$

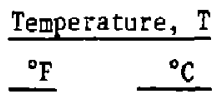

$100 \quad 37.8$

$200 \quad 93.3$

$300 \quad 149$

$400 \quad 204$

$500 \quad 260$

$600 \quad 316$

Temperature, $\mathrm{T}$

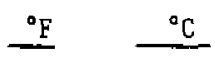

$100 \quad 37.8$

$200 \quad 93.3$

$300 \quad 149$

$400 \quad 204$

$500 \quad 260$

$600 \quad 316$

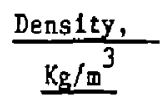

2941.3

2944.5

2947.7

2949.3

$? 952.5$

2955.7

Therma1 Diffusivity,

$\underline{2} / \mathrm{hr}$

.00191

.00187

.00182

.00177

.00173

.00168
Heat Capactity, CP

$\mathrm{J} / \mathrm{g} /{ }^{\circ} \mathrm{C}$

0.728

0.779

0.829

0.879

0.929

0.980

Thermal Conductivity, $k$

$w / w^{\circ} k$

1.12

1.19

1.24

1.28

1.32

1.30

Sample 1084 Depth $=330$ m $(1084 \mathrm{ft})$

\begin{tabular}{cc}
\multicolumn{2}{c}{ Ternerature, I } \\
\hline${ }^{\circ} \mathrm{F}$ & ${ }^{\circ} \mathrm{C}$ \\
\hline 100 & 37.8 \\
200 & 93.3 \\
300 & 149 \\
400 & 204 \\
500 & 260 \\
600 & 316
\end{tabular}

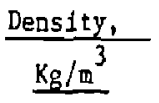

2660.9

2662.5

2665.7

2667.3

2670.5

2672.1
Heat Capacity, C? $\mathrm{J} / \mathrm{g} !^{\circ} \mathrm{C}$

.737

.783

.825

.867

.908

.950

Thermal Diffus 1vity,

\section{$\underline{m}^{2} / \mathrm{hr}$}

.00186

.00181

.00176

.00170

.00164

.00150
Thermal Conductivity, $k$

$w / m^{\circ} \mathrm{k}$

1.02

1.04

1.07

1.09

1. 11

I. 12 
TAPL $\overrightarrow{2-22}$ Heat capacity.

CONDUCTIVITY

$\mathrm{w} / \mathrm{m}^{\circ} \mathrm{K}$

$$
0.623
$$

0.346

0.398

0.415

0.433

0.301

0.322

0.343

0.363

0.384

0.405

0.305

0.324

0.341

0.358

0.376

0.393
TEST

CONDITIONS

$$
20-\overline{100^{\circ} \mathrm{C}}
$$

$100^{\circ} \mathrm{C}$

$200^{\circ} \mathrm{C}$

$300^{\circ} \mathrm{C}$

$37.8^{\circ} \mathrm{C}$

$93.3^{\circ} \mathrm{C}$

$148.8^{\circ} \mathrm{C}$

$204.4^{\circ} \mathrm{C}$

$260^{\circ} \mathrm{C}$

$315.6^{\circ} \mathrm{C}$

$37.8^{\circ} \mathrm{C}$

$93.3^{\circ} \mathrm{C}$

$148.8^{\circ} \mathrm{C}$

$204.4^{\circ} \mathrm{C}$

$260^{\circ} \mathrm{C}$

$315.6^{\circ} \mathrm{C}$

\section{REFERENCE}

Ratigan, 1976

LANGE'S Handbook

of Chemistry, 1956

Parsons 1976

11

ARH-ST-137, 1976

SOLRCE: Office of Nuclear Waste Isolation, 1978 
conductivity of basaltic rocks, as collected by Agapito et al, are shown in Table 2-23. Similarly, thermal diffusivity is shown in Table 2-24.

An equation for the inverse thermal conductivity as a function of temperature for Dresser basalt is given in Figure $2-24$. Note that the curve fits the data for three of the five blocks tested quite well. Values for specific heat for several rock types as a function of temperature are given in Figure 2-25. Both thermal conductivity and specific heat are strongly dependent on the chemical composition of the rock.

It is possible, using such models, to show the effect of uncertainty in one of the properties on the thermal distribution. The effect of thermal conductivity of the basalt layer on the cavern temperature is shown in Figure $2-26$. Note that increasing the thermal conductivity causes a large reauction in the maximum cavern temperature.

In summary, relat. 'el" attle information regarding the thermal properties basalt is presently available. At least one study, Hanford basalt is underway (Colorado School of Miner and the results should be available soon.

Table 2-26 lists a summary of average physical properties for basalt from Deere et al (1966). 
TABLE 2-23 Themal conductivity of basaltic rocks

\begin{tabular}{|c|c|c|}
\hline & $\begin{array}{l}\text { Temperature } \\
{ }^{\circ} \mathrm{K}\end{array}$ & $\begin{array}{c}\text { Thermal Conductivity } \\
w / t^{0} K\end{array}$ \\
\hline Basalt & $N A^{*}$ & $1.8-2.2$ \\
\hline Basalt (Japan) & NAH & 1.4 \\
\hline $\begin{array}{l}\text { Gabbro, Norites, } \\
\text { Diabase }\end{array}$ & $273-373$ & $1.7-2.5$ \\
\hline $\begin{array}{l}\text { Basalt, Columbia } \\
\text { Plateay }\end{array}$ & 373 & 1.53 \\
\hline Basalt, Dresser & 373 & 3.0 \\
\hline Basalt, Diabasic & 303 & 1.69 \\
\hline Basalt, Diabasic & 348 & 1.73 \\
\hline Average & & 2.2 \\
\hline
\end{tabular}

*Not Available

Source:

sapito et al, 1977 
TABLE 2-24 Thermal diffusivity

Rock Type

Cabbro

Fine-Grained Diabase

Silicified Diabase

Basalt (Japan)

Gabbro (Japan)

Basalt, Dresser

Basalt, Columbia Plateau

Avetage

Source: Agapito et al, 1977
Thenal Diffusivity

$0^{2} / 5 \times 10^{-7}$

5.2

5.8

8.1

7.0

8.0

10.0

6.5

7.0 


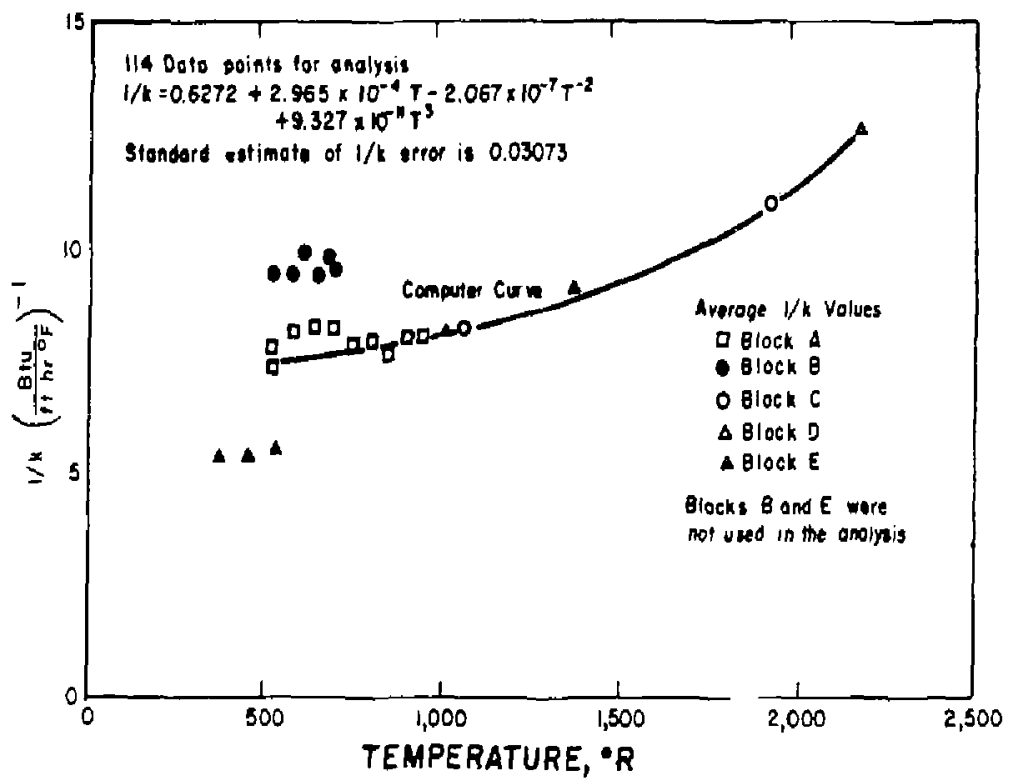

FIGURE 2-24 Inverse thermal conductivity versus temperature, Dresser basalt

Source: Marovelli a: " "e:th, 1965. 


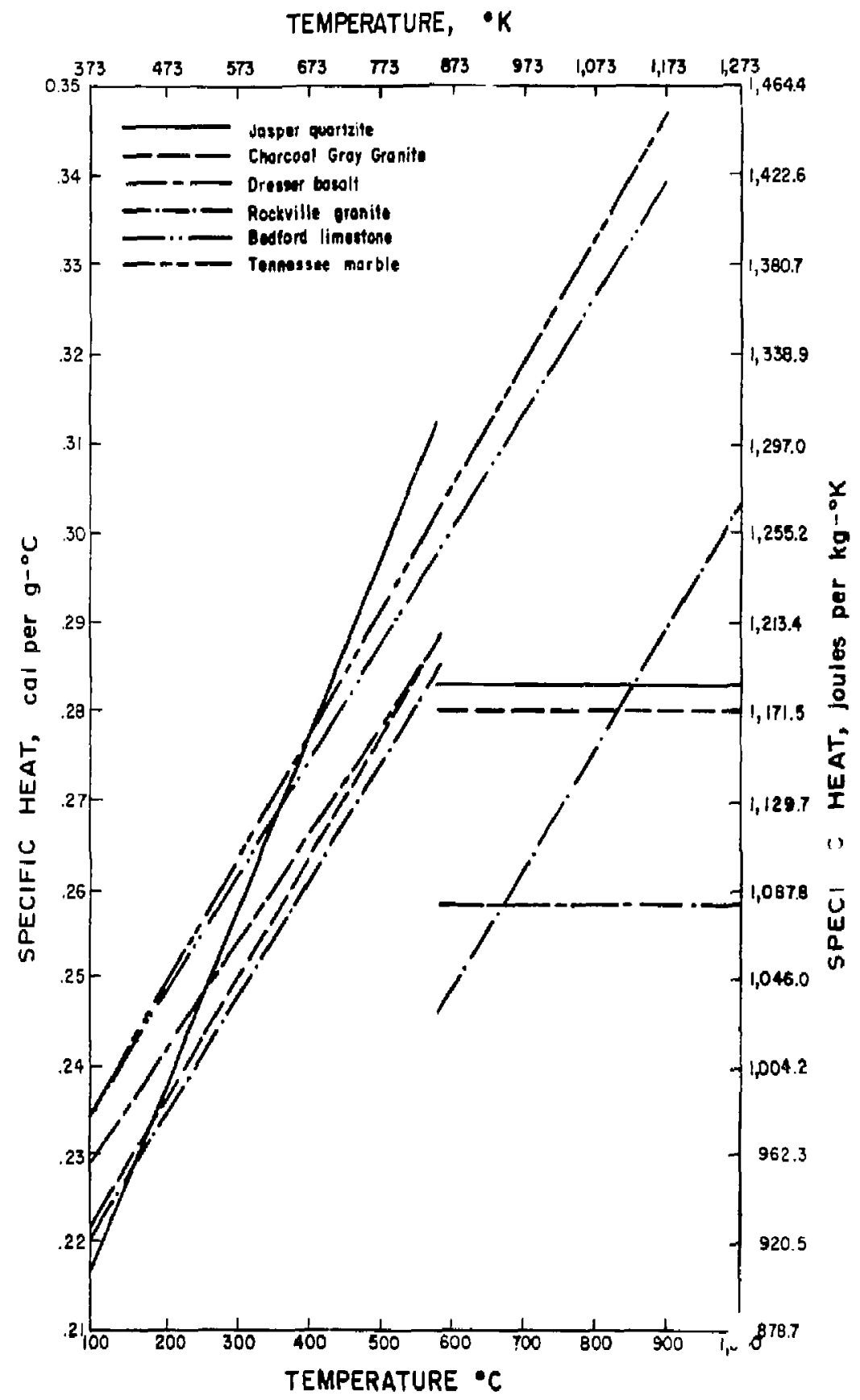

FIGURE 2-25 Comparison of the specific heats for the six rock types Source: Lindroth and Krawza, 1971. 


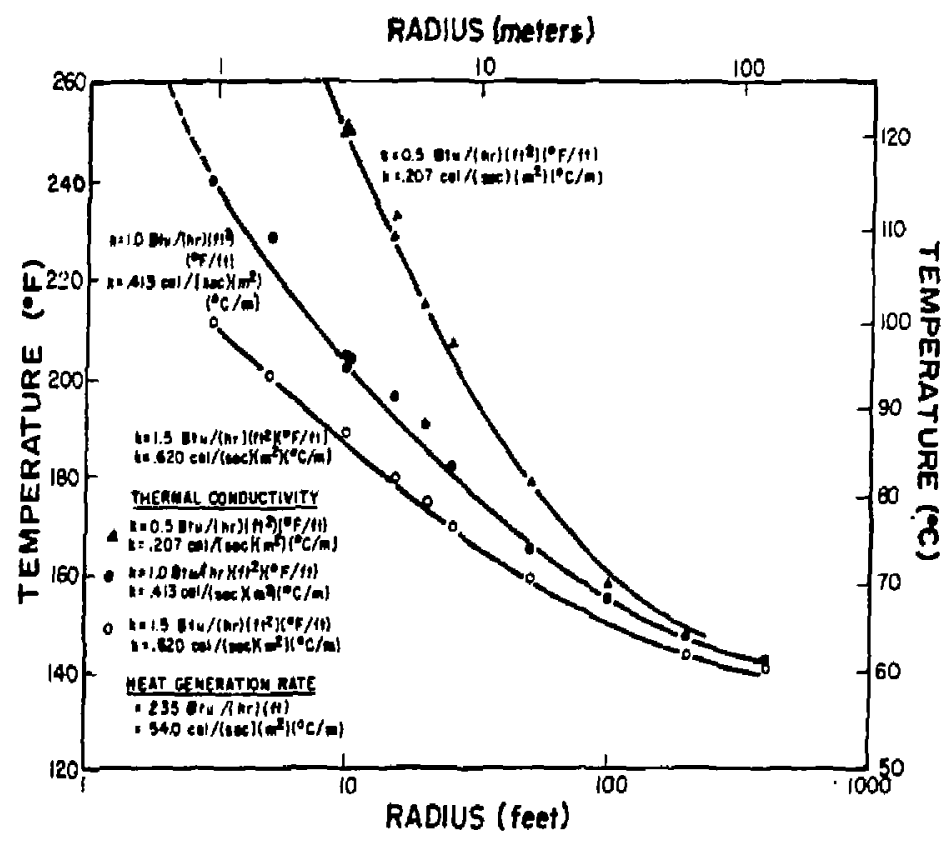

FIGURE 2-26 Cavern temperature versus cavern radius for varlous thermal conductivity values

Source: Arlantic Ricifield ilanford, 1396, v.1 


\begin{tabular}{|c|c|c|c|c|c|c|c|c|c|c|c|c|c|c|}
\hline $\begin{array}{l}\text { Group } \\
\text { So. }\end{array}$ & $\begin{array}{l}\text { Rock Type } \\
\text { sod } \\
\text { Location }\end{array}$ & & $\begin{array}{l}\text { lolt } \\
\text { Heleht. } \\
\text { Fosicas }\end{array}$ & $\left(1 b v / f e^{3}\right)$ & $2 / 0$ & 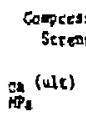 & $\begin{array}{l}\text { SLive } \\
\text { gch } \\
\text { Loud } \\
\text { isate } \\
\text { gra/sece }\end{array}$ & $\begin{aligned} \text { Sho } \\
\text { thentog }\end{aligned}$ & n.s.s & $\begin{array}{l}\text { Scinald } \\
\text { Harthess } \\
\text { Al! } \\
\text { RAgs. }\end{array}$ & $\begin{array}{c}2 \\
502 \\
5184 \\
302\end{array}$ & $\begin{array}{c}\text { oresion } \\
\text { ardoess } \\
A_{k} \\
\frac{1}{1} \\
\text { red }\left(0^{2}\right)\end{array}$ & $\begin{array}{l}\text { Aborption } \\
\text { : of dry } \\
\text { vetghe }\end{array}$ & $\begin{array}{l}\text { Tensile } \\
\text { streag: } \\
\text { Polat } \\
\text { Lont } \\
\text { PRe }\end{array}$ \\
\hline 1.1 & 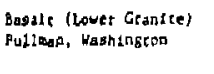 & $\begin{array}{l}\text { No. } \\
\text { Teteg } \\
\text { Va }\end{array}$ & $a_{1: 3}^{2.3}$ & $\begin{array}{c}(170.2) \\
12 \\
1.0\end{array}$ & $12^{2,08}$ & $\begin{array}{l}200 \\
55 \\
76.6\end{array}$ & .25 & $\begin{array}{c}79 \\
960 \\
7.6\end{array}$ & $\begin{array}{c}86 \\
580 \\
6.9\end{array}$ & $\begin{array}{c}53 \\
346 \\
9.3\end{array}$ & $\begin{array}{l}57 \\
72 \\
5.1\end{array}$ & $\begin{array}{l}.078 \\
.0026 \\
.0035\end{array}$ & $\begin{array}{l}1.92 \\
1\end{array}$ & $\begin{array}{r}: \pm 9 \\
13.8 \\
2.1\end{array}$ \\
\hline 1.2 & 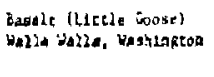 & $\begin{array}{l}\text { No. } \\
\text { Tesss } \\
\text { vz }\end{array}$ & 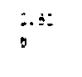 & $\begin{array}{c}(175.8) \\
6 \\
.4\end{array}$ & $\frac{2.22}{6}$ & $\begin{array}{l}397 \\
2 ! \\
40\end{array}$ & .01 & $\begin{array}{c}\pi \\
480 \\
6.5\end{array}$ & $\begin{array}{c}87 \\
240 \\
6.3\end{array}$ & $\begin{array}{l}5 i n \\
12 \\
9.0\end{array}$ & $\begin{array}{l}38 \\
36 \\
5.3\end{array}$ & $\begin{array}{l}.52: \\
.0026 \\
.0048\end{array}$ & $i^{.64}$ & $\begin{array}{r}10.6 \\
6.9\end{array}$ \\
\hline 1.3 & $\begin{array}{l}\text { ande (Joto Bay) } \\
\text { arilogues, Orepas }\end{array}$ & $\begin{array}{l}\text { No. } \\
\text { Tencs } \\
\text { vath }\end{array}$ & 2.87 & $\begin{array}{c}(179.1\rangle \\
6 \\
.5\end{array}$ & $6^{2.08}$ & $\begin{array}{r}395 \\
11 \\
4\end{array}$ & .06 & $\begin{array}{c}82 \\
480 \\
6.3\end{array}$ & $\begin{array}{c}91 \\
260 \\
4.6\end{array}$ & $\begin{array}{l}5 s \\
72 \\
7.3\end{array}$ & $\begin{array}{l}56 \\
36 \\
6.1\end{array}$ & $\begin{array}{l}.1 \% 5 \\
.0052 \\
.0057\end{array}$ & $i^{.75}$ & $\begin{array}{r}16.5 \\
6.9\end{array}$ \\
\hline
\end{tabular}

more: $n=$ confticient of rartacion

Sounce: boure at a, 2966 


\subsection{THLPMOELASTIC PROPERTIES}

The influence of temperature and pressure on the elastic properties of basaltic rocks will be discussed in this section. These elastic properties include Poisson's ratio, Young's modulus, and the coefficient of linear thermal Expansion. Tables 2-26-2-29 and Figure 2-27 show the effect of temperature on the elastic modulus and Poisson's ratio of various basalts and basalt like rocks. It is noted that for Dresser basalt, an increase in temperature from 297 $\mathrm{K}^{\circ}$ to $866^{\circ} \mathrm{K}$ results in a reduction in modulus from 100 down to $66 \mathrm{GPa}$. For the same temperature range, Poisson's ratio is reduced by about half.

There is very little data presently available regarding the relationship between compressive strencth and temperature. Figure 2-28 reveals that under static loading, the strength of Dresser basalt decreases rather dramatically over the temperature range of 0 to $400^{\circ} \mathrm{K}$ but then levels off. The factor of 2 decrease from room temperature to $400^{\circ}$ is of great impcrtance since the rock in the near vicinity of the canister would undergo such a change.

Average values of the coefficient of linear thermal expansion for a number of rocks are given in Table 2-30. This coefficient, however, has been found for most rocks to 
TABLE 2-26 Esample of influence of temperature and pressure on the elastic properties of some basaltic rocks

\begin{tabular}{|c|c|c|c|c|}
\hline & $\underset{{ }^{\circ}}{\text { Temp. }}$ & $\begin{array}{c}\text { Pressure } \\
\mathrm{MPa}\end{array}$ & $\begin{array}{c}\text { Young's Modulus } \\
\text { GPa }\end{array}$ & $\begin{array}{l}\text { Poisson's } \\
\text { Ratio }\end{array}$ \\
\hline $\begin{array}{l}\text { Basalt, Homblende, } \\
\text { Chaffee County, Colorado } \\
\text { Density }=2,586 \mathrm{~kg} / \mathrm{m}^{3}\end{array}$ & $\begin{array}{l}298 \\
573\end{array}$ & $\begin{array}{r}50 \\
500 \\
50 \\
500\end{array}$ & $\begin{array}{l}67.5 \\
70.8 \\
63.7 \\
69.7\end{array}$ & $\begin{array}{l}.246 \\
.269 \\
.249 \\
.276\end{array}$ \\
\hline $\begin{array}{l}\text { Gabbro, "San Marcos," } \\
\text { Escondido, Califormia } \\
\text { Densiry }=2,993 \mathrm{~kg} / \mathrm{m}^{3}\end{array}$ & $\begin{array}{l}298 \\
573\end{array}$ & $\begin{array}{r}50 \\
500 \\
50 \\
500\end{array}$ & $\begin{array}{l}96.0 \\
99.8 \\
88.3 \\
98.3\end{array}$ & $\begin{array}{l}.363 \\
.375 \\
.334 \\
.370\end{array}$ \\
\hline $\begin{array}{l}\text { Gabtro, 5:lonnite, } \\
\text { Disuth, Kinnesota } \\
\text { Densit: }=2,555 \mathrm{~kg} / \mathrm{m}^{3}\end{array}$ & $\begin{array}{l}298 \\
573\end{array}$ & $\begin{array}{r}50 \\
500 \\
50 \\
500\end{array}$ & $\begin{array}{l}90.1 \\
95.3 \\
78.1 \\
90.1\end{array}$ & $\begin{array}{l}.343 \\
.362 \\
.303 \\
.342\end{array}$ \\
\hline $\begin{array}{l}\text { Cabbro, Hormblende } \\
\text { Location Linnown } \\
\text { Density }=2,933 \mathrm{~kg} / \mathrm{m}^{3}\end{array}$ & $\begin{array}{l}298 \\
573\end{array}$ & $\begin{array}{r}50 \\
500 \\
50 \\
500\end{array}$ & $\begin{array}{r}98.1 \\
105.4 \\
87.8 \\
103.7\end{array}$ & $\begin{array}{l}.378 \\
.407 \\
.345 \\
.403\end{array}$ \\
\hline
\end{tabular}




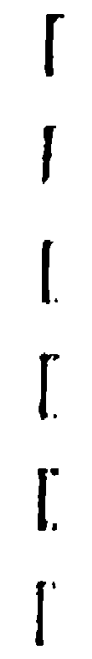

IABLE 2-27 Experimental values of Young's Modulus and Poisson's ratio at elevated temperatures in Dresser basalt

Sirurce: (wingquist, 1969)

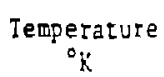

Elastic Modulus $\mathrm{GPa}$

297

100.7

0.24

395

98.6

0.24

533

95.1

$0 . ?$

644

87.6

0.1

755

83.4

0.18

E11

79.9

0.16

866

66.5

0.11

Poisson's Ratio

i

0.11

1

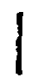

1.

1.

1

1

1

I

1 


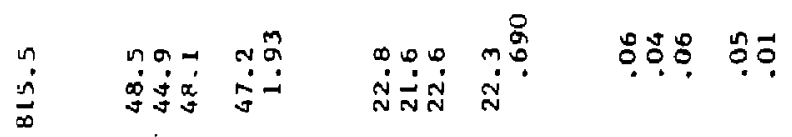

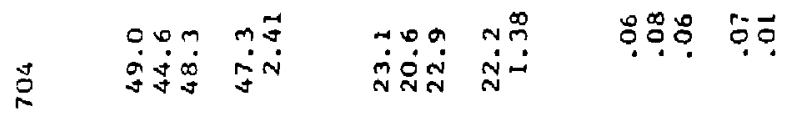
\&

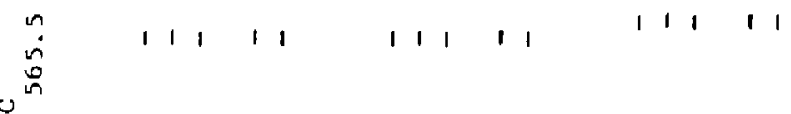
F

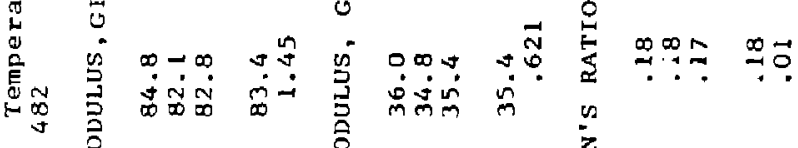

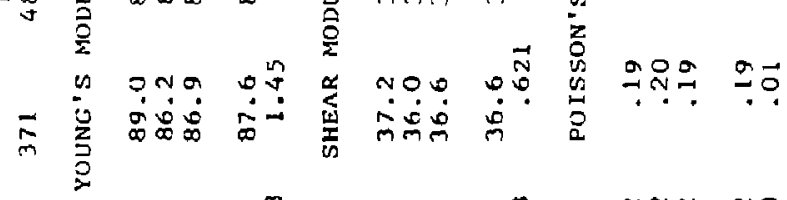

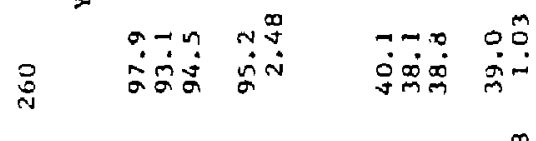
บกำ กับ

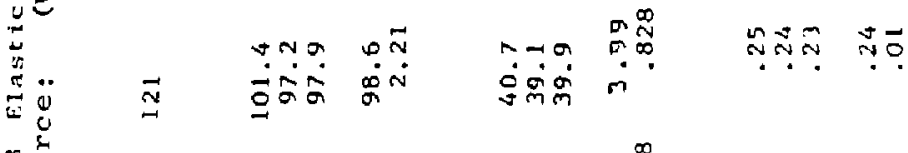

*

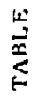

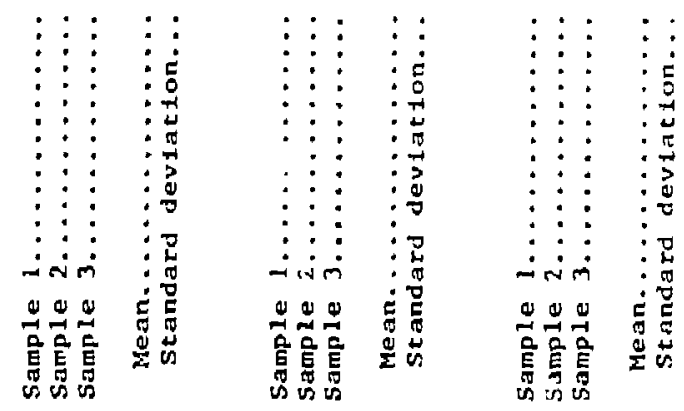


TABLE 2-29 Properties of Dresser basalt.

(Lehnhoff and Scheller, 1975)

\begin{tabular}{|c|c|c|c|}
\hline \multicolumn{4}{|c|}{ Dresser Basalt } \\
\hline & $\begin{array}{l}\text { Young's } \\
\text { Modul us }\end{array}$ & Poisson's & $\begin{array}{l}\text { Coef } f \text {, of } \\
\text { Therwal }\end{array}$ \\
\hline Temperature & $\mathrm{E}, 10^{5}$ & Ratio & Expansion \\
\hline${ }^{\circ} \mathrm{C}$ & $\mathrm{MPa}$ & $v$ & $\alpha, 10^{5} /{ }^{\circ} \mathrm{C}$ \\
\hline 24 & 1.007 & 0.24 & 0.290 \\
\hline 122 & .9860 & 0.24 & 0.500 \\
\hline 260 & .9510 & 0.22 & 0.770 \\
\hline 371 & .8760 & 0.19 & 0.940 \\
\hline 482 & .8340 & 0.18 & 1.020 \\
\hline 538 & .7990 & 0.16 & 1.080 \\
\hline 593 & .6650 & $0.1 !$ & 1.160 \\
\hline 700 & .0010 & 0.10 & 1.160 \\
\hline
\end{tabular}


TEMPERATURE. “K
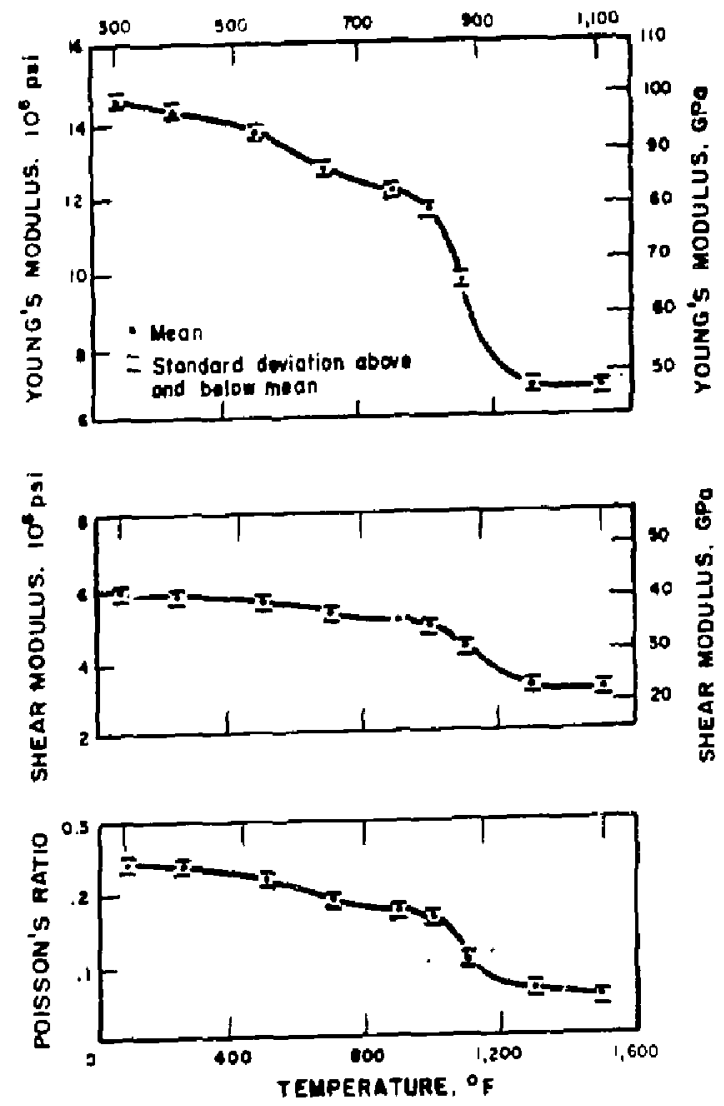

FIGURE 2-27 Elastic moduli and Folson's Ratio es functio of tenperature for brester baile.

Source: Wingquit, 1969. 


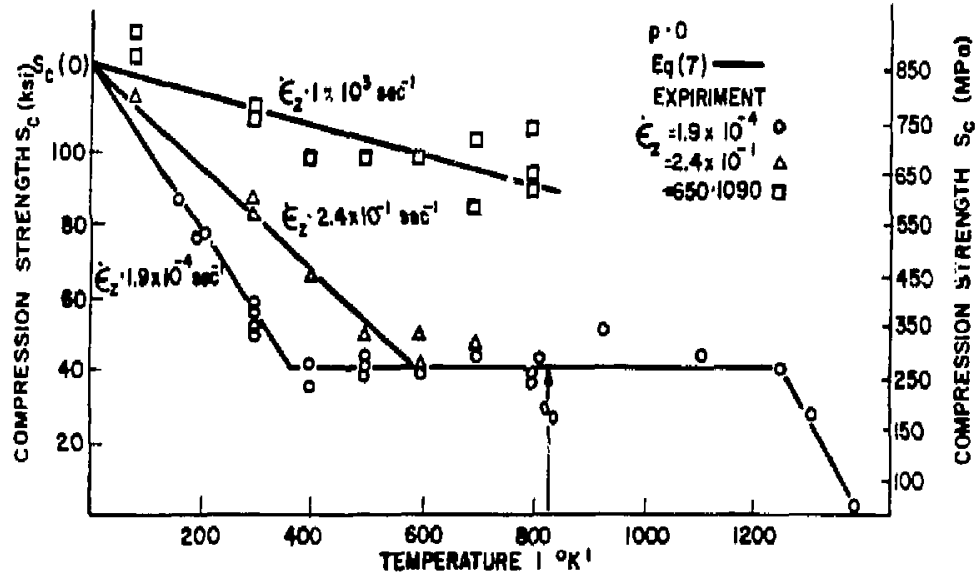

FIGURE 2-28 Influence of temperature and strain rate on strength of Dresser basalt

Source: Krumer, 1968. 
TABLE 2-30 Coefficient of linear themal expansion.

Rock Type

Basalts, Gabbros, Diabase

Basalt $\left(300^{\circ} \mathrm{K}\right)$

Eairfax Diabase

Cape Neddick Gabbro

Dresser Basalt
$2.9-11.6$

Reference

$$
\times 10^{-6} /{ }^{\circ} \mathrm{K}
$$

5.4

9

$4.3-6.5$

6

15.9

12

8.5

12

13

Agapito et al, 1977 
depend on temperature and some typical results for Dresser basalts are given in Table 2-29. Note that for temperature of $24^{\circ} \mathrm{C}$, the coefficient of the thermal expansion is $.29 \times 10^{-5}$. At $700^{\circ} \mathrm{C}$, the same coefficient is $1.16 \times 10^{-5}$.

If there is any gap between the canister and the rock las will most certainly be the case in any practical situation), these thermally induced stresses and displacements can cause the material directly around the canister to degrade or spall during the heating process. The effects of this thermal degradation can be evaluated by numerical models. Such a modeling study was done by Hardy \& Hocking. They examined the influence of changes in basalt thermal conductivity which result from the failure of the basalt.

The coupling between thermal and mechanical response, which was used for modeling the effects of borehole decrepitation was a volumetric strain-dependent thermal conductivity. They suggest that this type of coupling is supported by observation since during rock failure, micro-cracks and void spaces develop and, hence, the volumetric strain increases

The development of such voids in the rock will lead to a reduced thermal conductivity and thereby restrict the flcw of heat from the canister into the rock. In their analysis, 
they assumed the thermal conductivity volumetric strain relationship showin in Figure 2-29. The form shows a reduction in thermal conductivity to one quarter of initial values for large volumetric strains. The expected temperatures for the case with thermomechanical coupling (Figure 2-30) is compared with the case for constant thermal conductivity in Figure 2-31. This shows that for a $1 \mathrm{~kW}$ heat source, the reduced thermal conductivity of the rock adjacent to the canister results in an increase of 208 in the canister temperature. This cannot be considered significant. For higher thermal outputs, increased rock failure could produce a more extensive zone of reduced conductivity and, hence, lead to thermal runaway. It is noted that there are no laboratory data available at this point to support such thermal conductivity-volumetric strain curve as shown in Figure 2-29, but the consequences are severe, (breakdown of waste forms, glass for example, greatly reduced canister life, etc.) and, therefore, input data must become available.

A summary of thermomechanical properties for basalt as prepared by Agapito et al is given in Table 2-31. 


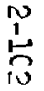

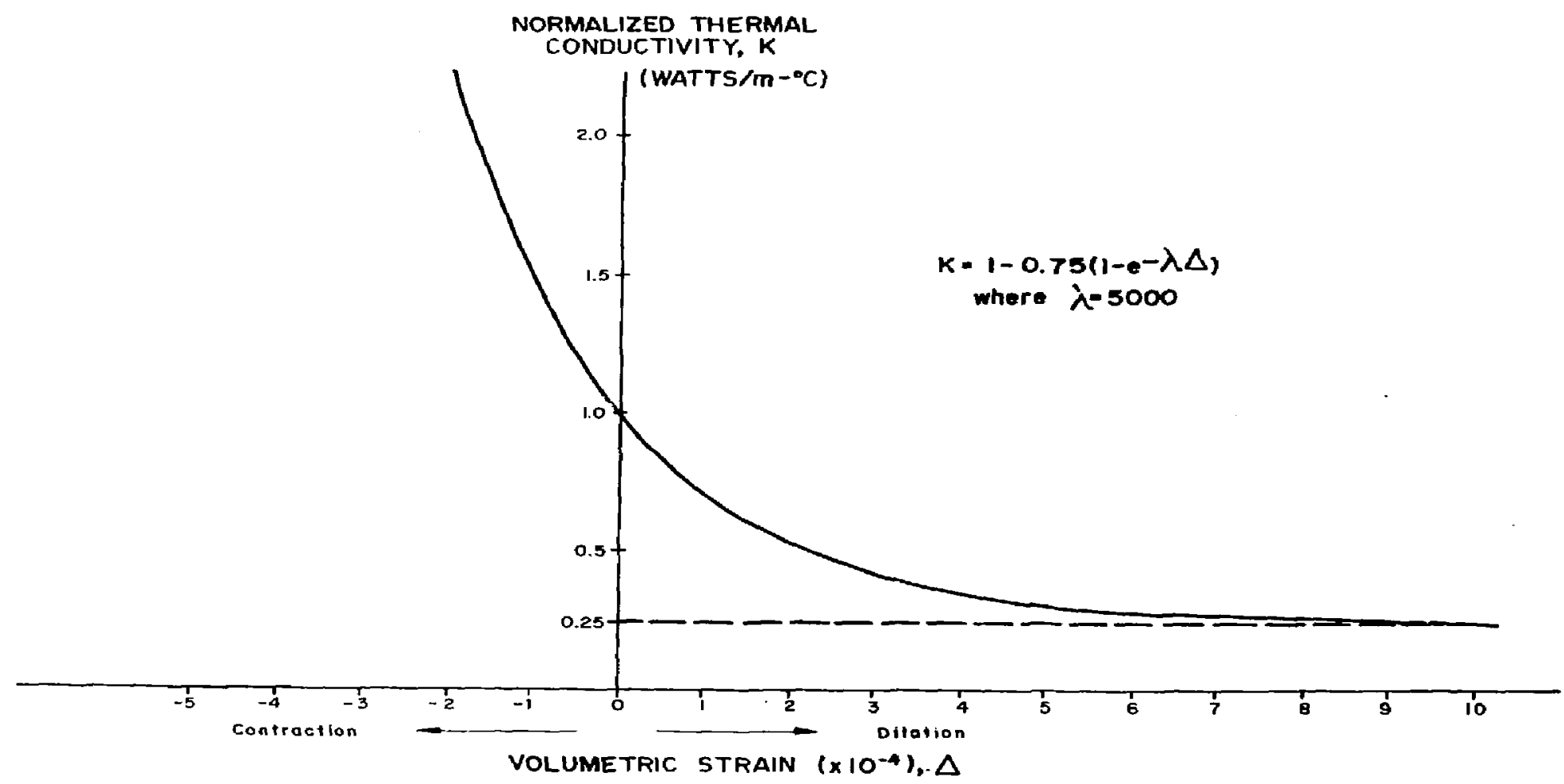

FIGURE 2-29 Form of thetmal conductivity - volumetric stratn celationship Source: Hardy and Hocking, 1977. 


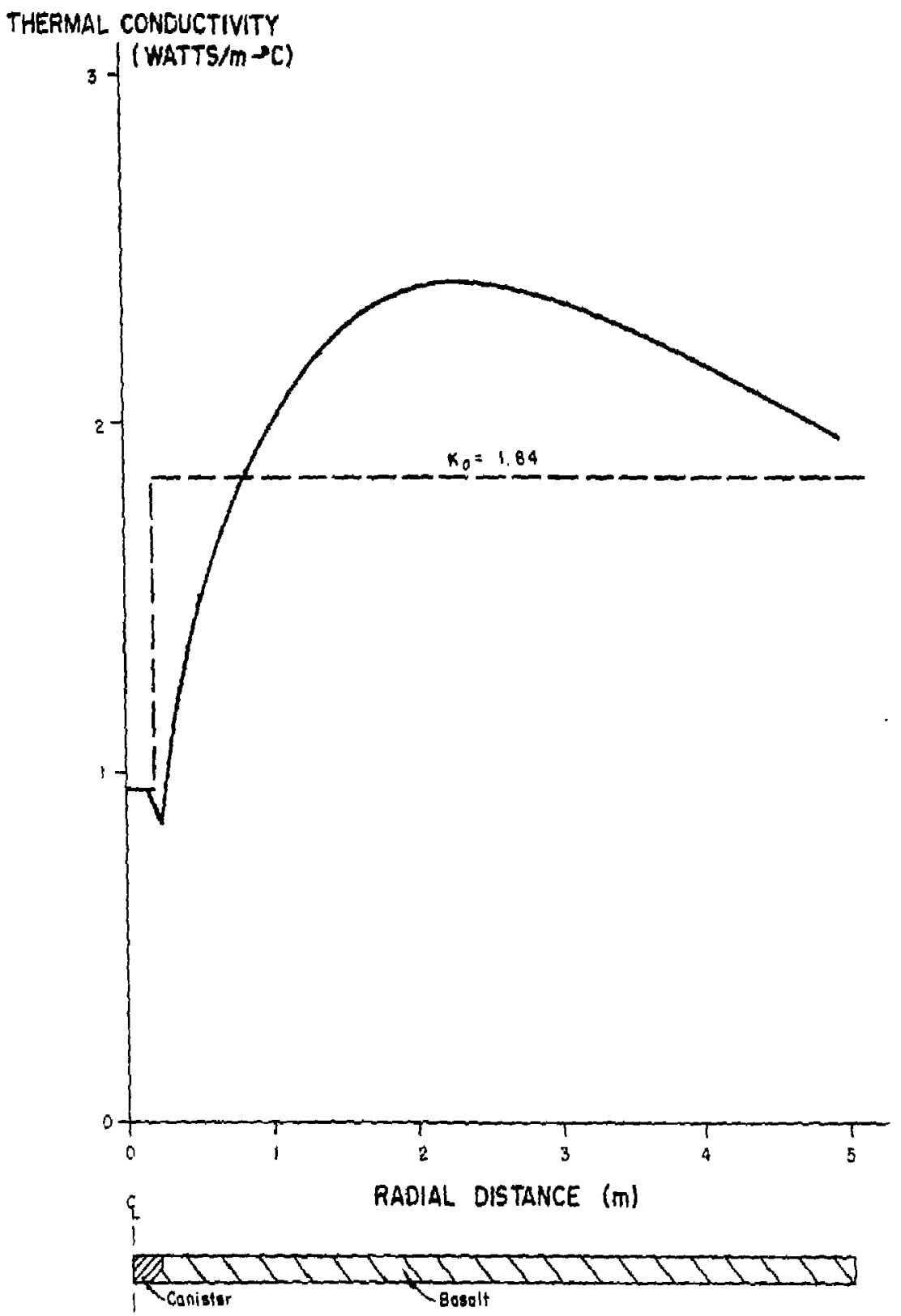

FIGURE 2-30 Conductivity versus radial distance aiter 28 days Source: Hardy and Hocking, 1977. 
TEMPERATURE (C)

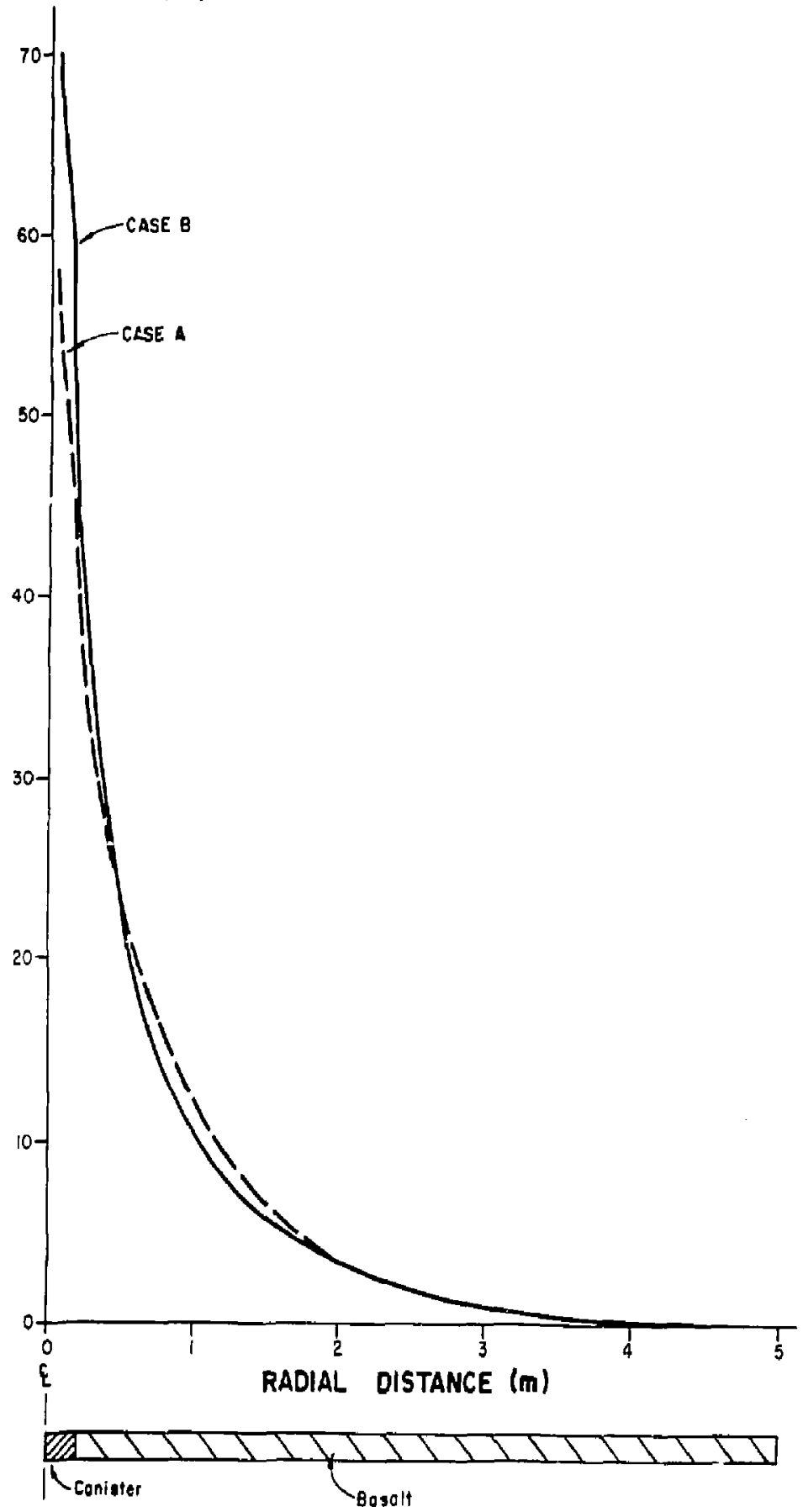

FIGURE 2-31 Comparison of temperatures for uniform conductivity (case A) and basalt decrepitation (case B) Source: Hardy and Hocking, 1977. 
TABLE 2-31 Sumary of thermomechanical basalt properties.

$\begin{array}{lcccc}\text { Property } & \begin{array}{c}\text { Estimated } \\ \text { Value }\end{array} & \text { Range } & \text { Units } & \begin{array}{c}\text { Major } \\ \text { Influence }\end{array} \\ \text { Density } & 2.9 & 2.4-3.1 & \mathrm{~g} / \mathrm{m}^{3} & \text { Porosity } \\ \text { Diffusivity } & 6.5 \times 10^{-7} & 5.2,8.0 \times 10^{-7} & \mathrm{~m}^{2} / \mathrm{s} & \text { Porosity }\end{array}$

Thermal

Conductivity

$1.5 \quad 1.4,4.28 \quad w / \pi^{\circ} \mathrm{K}$

Specific Heat $\quad 1.0 \quad 0.95,1.05 \quad \mathrm{~kJ} / \mathrm{kg}^{\circ} \mathrm{K}$

Themal Expansion

Coefficlent

$5.4 \times 10^{-6}$

2.9. $11.6 \times 10^{-6} \quad /{ }^{\circ} \mathrm{K}$

Temperature

Young's Modulus

70

61, 112

GPa

Poisson's Ratio

0.26

$0.22,0.28$

Uniaxial

Compressive

Strength

200

0,400

$\mathrm{MPa}$

Porosity,

Angle of

Internal

Fiction

$55^{\circ}$

45,60

$x^{\circ}$

Jointing

Tensile Strength

14

$0,23.0$

$\mathrm{YPa}$

Jointing

SOURCE: Agapt to et al, 1977 


\subsection{OTHER CONSIDERATIONS}

Due to the elevated temperatures and the long life of the repository, the possibility of long-term deformation through creep must be considered. Unfortunately, the time-dependent behavior of basalt over the temperature and stress range of interest for radioactive waste disposal is not well documented. The compressive strength as a function of creep rate for Anchitka basalt is shown in Table $2-32$. Dense basaits appear to have a low uniaxial creep rate and exhibit a minimum average amount of irrecoverable strain. Some creep curves for basalt as presented by Iida (1960) are shown in Figure 2-32. A11 of these tests were performed at approximately room temperature. 
TABLE 2-32 Creep and fallur a characteristics of Amchita Island rociss under unfaxial compressive stress (Sharp, 1972)

$\begin{array}{cccc} & \text { LEGEND } & \text { CREEP RATE } & \text { IRRECOVERABLE STRAIN } \\ \text { GROLP } & \text { See } & \text { Microstrains/hr, extrapolated } & \text { Percent, after loading to } \\ \text { No. Notes } & \text { to a time of } 200 \text { minutes } & \text { one-half ultimate strength }\end{array}$

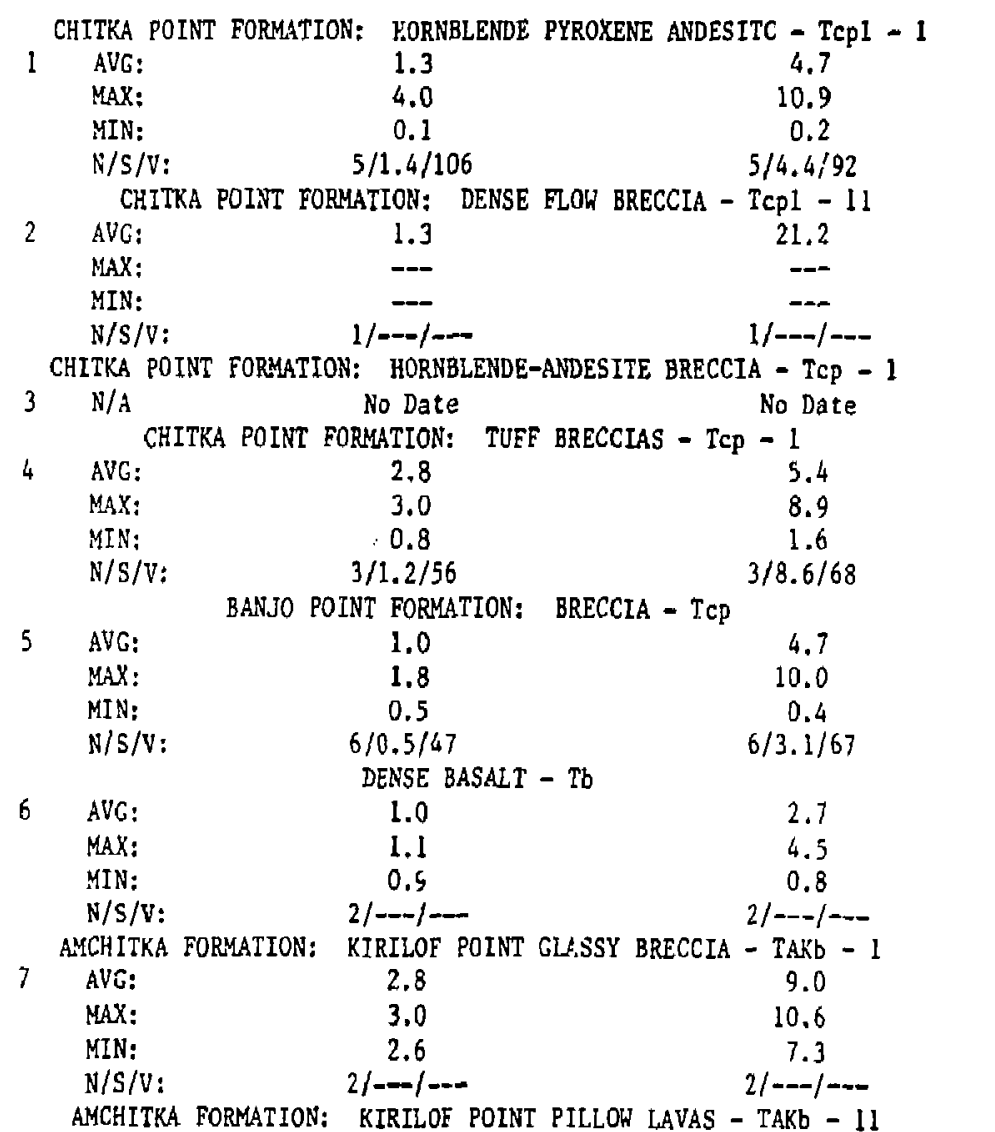
B AVG:
0.9
MAX: $\quad 1.4 \quad 2.1$
MIN: $\quad 0.4 \quad 1.3$
N/S/V: 2/---/--- 2/---/---
AMCHITKA FORMATION; DENSE OLDER BRECCIA - TAb
9 AVG: $\quad 1.7 \quad 5.4$
MAX: $\quad 2.5 \quad 8.2$
MIN: $\quad 0.7 \quad 2.6$
N/S/V: $\quad 4 / 1.0 / 58 \quad 4 / 2.5 / 46$

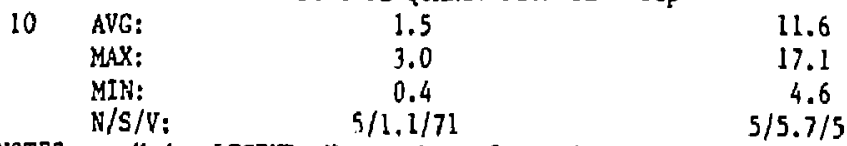

NOTES: Under LEGEND, $N$ - Number of specimens; $S$ = Standard deviation; $v=C^{2} f$ icient of variation in percent, respectivelv. 


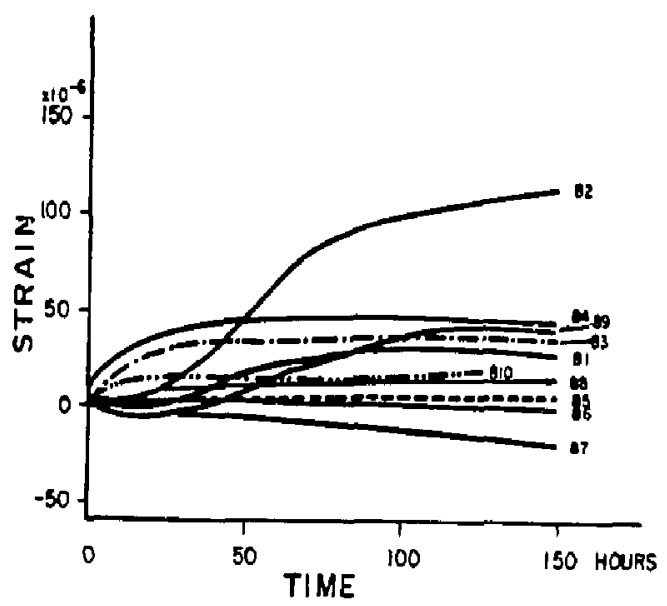

B1: $20.2 \mathrm{~kg} / \mathrm{cm}^{2} .27 .5^{\circ} \mathrm{C} . \quad 82: 32.6 \mathrm{~kg} / \mathrm{cm}^{2} .27 .5^{\circ} \mathrm{C} . \quad$ 83: $45.6 \mathrm{~kg} / \mathrm{cm}^{2} .28^{\circ} \mathrm{C}$. $84: 58.3 \mathrm{~kg} / \mathrm{cm}^{2}, 28^{\circ} \mathrm{C}$. B5 $73.5 \mathrm{~kg} / \mathrm{cm}^{2} .18^{\circ} \mathrm{C}, \quad 86: 83.4 \mathrm{~kg} / \mathrm{km}^{2}, 28^{\circ} \mathrm{C}$, 87: $92.3 \mathrm{~kg} / \mathrm{cm}^{2} .28^{\circ} \mathrm{C} .88: 138.9 \mathrm{~kg} / \mathrm{km}^{2}$. $11^{\circ} \mathrm{C} . \quad 89: 161.7 \mathrm{~kg} / \mathrm{cm}^{2} .27 .5^{\circ} \mathrm{C}$, B10: $216.0 \mathrm{~kg} / \mathrm{cm}^{2} .16^{\circ} \mathrm{C}$.

EIGLRE 2-32 Creep CuIves tar basalc Source: Itda et il, $: 0: 0$ 


\subsection{SCALING OF LABORATORY RESULTS}

As was indicated in the introduction to this report, basalt can vary considerably in the flows, both horizontally and vertically. One significant structural characteristic of many basalts is their jointing pattern. As previously discussed, these jointing patterns can take many forms. One common form is columnar jointing. It is expected that rock mass properties of the basalt will be considerabiy different from the intact properties due to the complex interaction of ithe intact rock, joilit system, foint filling, and water effects.

In their report, the Office of Nuclear Waste Isolation, (1978) have presented a discussion of how one uight go from intact values to rock mass values. Their discussion is axtremely worthwhile to include, as it presents the state of the art regarding this important characterization:

"The rock-mass properties of a basalt will be considerably different from the intact properties, due to the complex interaction of the rock substance, joint system, joint filling and water effects.

For two important design parameters, namely, Young's Modulus and Unconfined Compressive Strength, the rock-mass values are typically much smaller than the intact values. In each case the rock-mass value is usually rbtained from the intact value by multiplying by an appropriate reduction factor; i.e.

Reduction Factor, $\mathrm{R}=\frac{\text { Rock-Mass Value } \text { (Strength\} }}{\text { Intact Value (Strength) }}$ 
Considerable judgment is required in selecting a suitable reduction factor. This is because the reduction factor depends very much on geological considerations, such as the joint pattern, joint spacing and joint filling. Although the rock-mass properties (and hence, reduction factors) may be determined directly from large-scale field tests, these are time-consuming, and expensive; this largely explains why no large-scale field tests have been reported in ti.e literature.

Since geological structure plays a very important role in rock-mass behavior, a description of structures found in a typical basalt is presented in Table 2-33. These structures have been taken into account in deriving the rock-mass properties.

The rock-mass properties of a typical dense basalt representative of the lower portion of a thick flow are given in Table 2-34. The moduli and strength characteristics were determined by the use of reduction factors applied to the representative intact data.

It was necessary to use a considerable amount of judgment in arriving at a reduction factor of 0.18 for Young's modulus. A certain amount of weight was given to considerations by Panek (1970) in which the reduction factor is related to the fracture spacing and the width of the excavation. Due largely to the relatively close jointing in basalt, which we have assumed to have an average spacing of about two feet, a reduction factor of 0.18 was chose. This then gave a Young's modulus of 12.4GPa for the rock mass.

Although jointing also has a considerable effect on rock-mass strength it is not considered to be as significant as with Young's modulus. Hence, a reduction factor of 0.45 was used which gives a uniaxial confined compressive strength of $124 \mathrm{MPa}$ for the rock mass.

The strength of the rock mass is considerably reduced at elevated temperatures. This reduction in strength has been taken into account in the calculations of tunnel and pillar stability; it is discussed further in the report on thermal stress analysis. 
TABLE 2-33 Partial description of typlcal structures in basalt

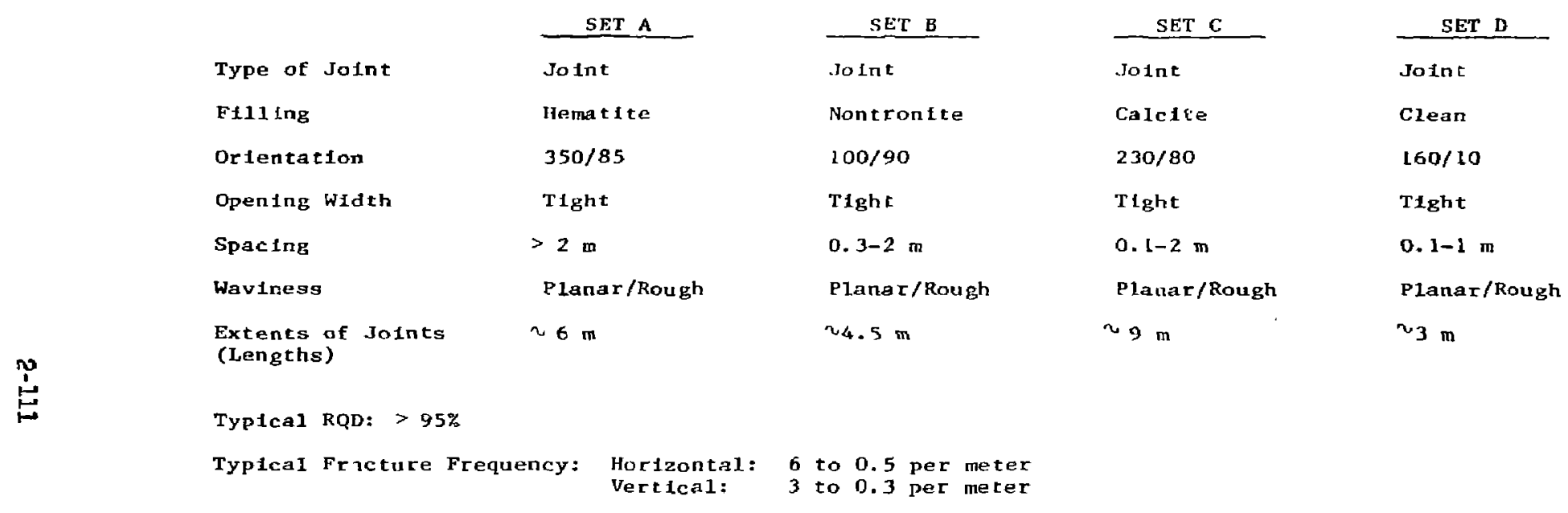


The non-linear failure curve that is recommended for a typical basalt at roorr temperature is shown in Figure 2-33. It may be described by the following three parameters:

$$
\begin{array}{ll}
\text { Unconfined compressive strength } \sigma_{c}=124 \mathrm{MPa} \\
\text { Curve fitting parameter, } & \mathrm{A}=4.5 \\
\text { Curve fitting parameter, } & \mathrm{k}=0.75
\end{array}
$$

A value of $2,880 \mathrm{~kg} / \mathrm{m}^{3}$ was assumed to be the unit weight of the basalt rock mass. Thermal properties at depth were assumed to be similar to the intace properties.

Although isotropic behayior has been assumed in this general study, anisctropic behavior should be investigated at the design stage for a specific repository; for instance, detailed geological mapping and in situ testing will be required at the actual site of the underground repository". (Office of Nuclear Waste Isolation, 1978)

In their approach, rock-mass value is related to the intact value through a reduction factor "R". As is noted, "it was necessary to use a considerable anunt of judgment is arriving at a reduction factor of 0.18 for Young's modulus". The same type of judgment entered into considering a reduction factor of 0.45 for the uniaxial compressive strength. There is no justification other than intuitive feeling for the choice of such reduction factors. Assume for the moment that a strength reduction function such as

$$
{ }_{\frac{1}{\sigma}}^{\sigma_{c}}=A\left({ }^{\sigma} \frac{3}{\sigma_{c}}\right)^{k}+I
$$

does exist for basalt $\left(A=4.5, k=0.75, Q_{c}=124 \mathrm{MPa}\right)$. If one wanted to calculate the rock-mass strength $\left(\sigma_{1}\right)$ under a confining stress $\left(\sigma_{3}=10 \mathrm{MPa}\right)$, then

$$
\sigma_{1}=\sigma_{c}\left\{A\left(\frac{\sigma}{\sigma_{c}}\right)^{k}+1\right\}=1.68 \sigma_{c}=208 \mathrm{MPa}
$$




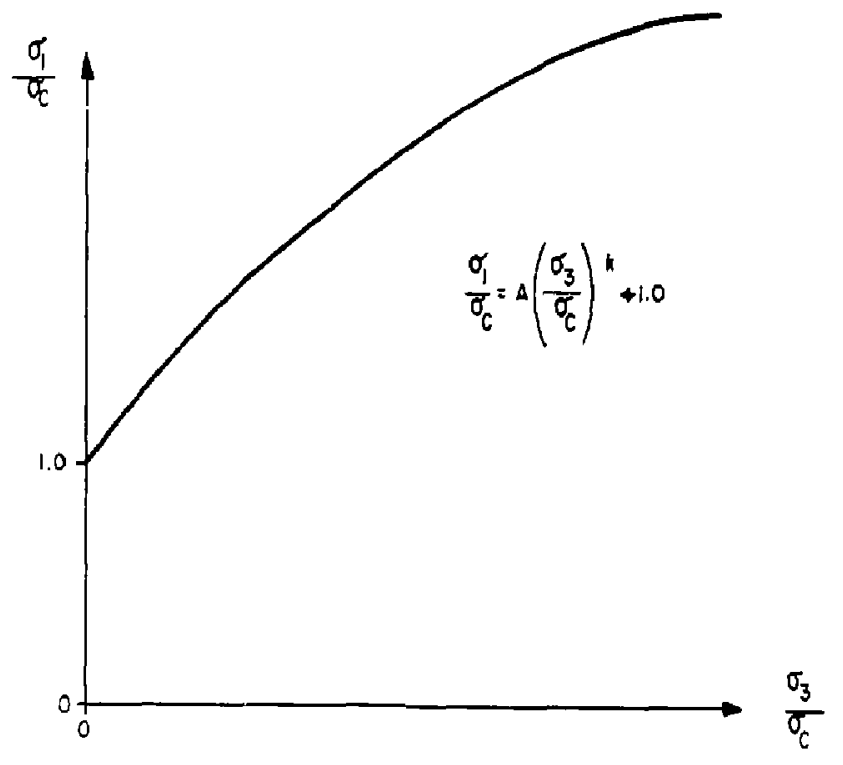

EIGURE 2-33 Non-1 lisear curve of strength for rock mass Source: Hardy and Hocking, 1977. 
The values of $A$ and $k$ are presumably determined from a suite of tests performed on small samples. Only the value of $\sigma_{c}$ requires scaling from small to large samples and this is done through the reduction factor $R$. A great amount of laboratory and field testing is required before any such simplified way of inferring from small to large scale properties for hard rock can be done.

In Table 2-34, in which intact properties are compared to rosk-mass properties for a typical dense basalt, no justification has been given for the reduction factors other than for modulus and compressive strength. Thermal expansion, for example, is indicated to be the same for the intuct and the rock mass. It is believed that this is probably far from true. The presence of joints in a rock mass influences its elastic properties, strength, thermal conductivity (Figure 2-34) and thermal expansion coefficient. The stress across the joint influences all these properties and as the stress history of the joints will change during the mining of the repository, the response of the joints durin; and after this stress change is of primary concern.

The behavior can be very non-linear as shown as idealized curves in Figures 2-34 - 2-36. 
TABLE 2-34 Intact properties for a tvpical dense basalt

\begin{tabular}{|c|c|c|c|c|}
\hline TYPE OF PROPERTY & PARAMETER & $\begin{array}{l}\text { INTACT } \\
\text { VALUE }\end{array}$ & $\begin{array}{l}\text { ROCK MASS } \\
\text { VALUE }\end{array}$ & MKS UNLTS \\
\hline Index & $\begin{array}{l}\text { Density } \\
\text { - Natural Moisture } \\
\text { Content } \\
\text {. Porosity }\end{array}$ & 3.01 & $--\overline{6}$ & $\begin{array}{l}\% \\
\%\end{array}$ \\
\hline Stress-strain & $\begin{array}{l}\text { - Young's Modulus } \\
\text { - Polsson's Ratio }\end{array}$ & $\begin{array}{l}69 \\
0.26\end{array}$ & $\begin{array}{l}12.4 \\
0.25\end{array}$ & $\begin{array}{c}\text { GPa } \\
--\end{array}$ \\
\hline Strength & $\begin{array}{l}\text { - Strength Parameters } \\
\text { A } \\
\mathbf{k} \\
\text { - Untaxia Compressive } \\
\text { Strength } \\
\text { - Tensile Strength }\end{array}$ & $\begin{array}{l}276 \\
16\end{array}$ & $\begin{array}{l}4.5 \\
0.7 ! \\
124 \\
0\end{array}$ & $\begin{array}{l}\text { MPa } \\
\text { MPa }\end{array}$ \\
\hline Therma I & $\begin{array}{l}\text { Coefficient of } \\
\text { Linear Thermal } \\
\text { Expansion } \\
\text { - Heat Gapacity } \\
\text { TEMPERATURE } \\
0^{\circ} \mathrm{C} \\
100^{\circ} \mathrm{C} \\
200^{\circ} \mathrm{C} \\
300^{\circ} \mathrm{C} \\
\text { Therma } 1 \text { Conductivity } \\
\text { TEMPERATURE } \\
0^{\circ} \mathrm{C} \\
50^{\circ} \mathrm{C} \\
100^{\circ} \mathrm{C} \\
150^{\circ} \mathrm{C} \\
200^{\circ} \mathrm{C} \\
300^{\circ} \mathrm{C} \\
400^{\circ} \mathrm{C}\end{array}$ & $\begin{array}{l}1.7 \times 10^{-6} \\
\text { HEAT CAPACITY } \\
0.71 \mathrm{~J} / \mathrm{g}^{\circ} \mathrm{C} \\
0.80 \\
0.92 \\
0.96\end{array}$ & $\begin{array}{l}1.7 \times 10^{-6} \\
\text { HEAT GAPACITY } \\
0.71 \mathrm{~J} / \mathrm{g}{ }^{\circ} \mathrm{C} \\
0.80 \\
0.92 \\
0.96 \\
\text { THERMAL } \\
\text { CONDUCTIVTTY } \\
1.12 \mathrm{w} / \mathrm{m}^{\circ} \mathrm{K} \\
1.19 \\
1.26 \\
1.32 \\
1.38 \\
1.47 \\
1.56\end{array}$ & ${ }^{\circ} \mathrm{C}^{-1}$ \\
\hline
\end{tabular}




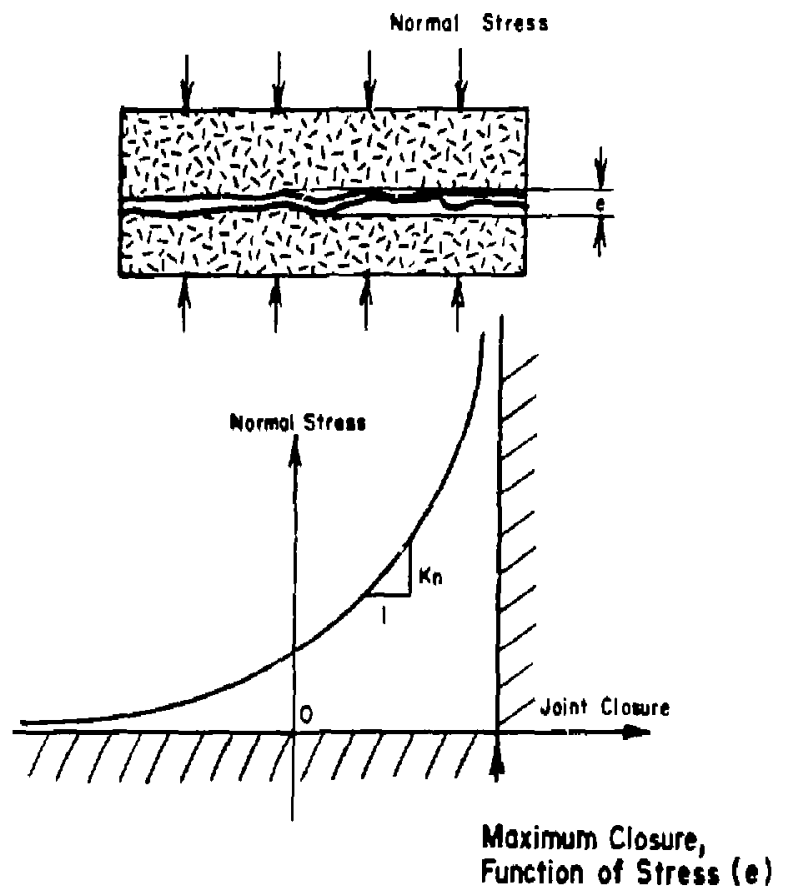

FIGURE 2-34 Influence of normal stress on normal stiffness $\left(K_{\mathrm{w}}\right)$ of a foint Source: Agapito et al, 1977. 

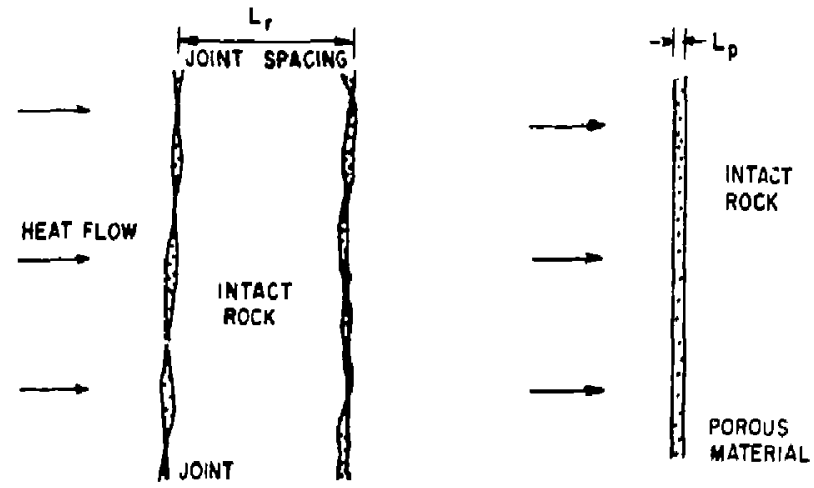

IDEALIZED JOINT

\section{SCHEMATIC IDEALIZATION OF A JOINT FOR ESTIMATION} OF THERMAL CONDUCTIVITY

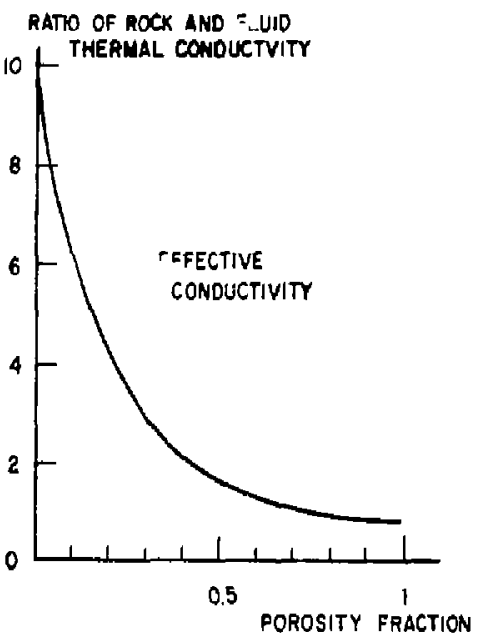

FIGURE 2-35 Tiermal conductivity of porous material Source: Agaplto et al, 1977. 


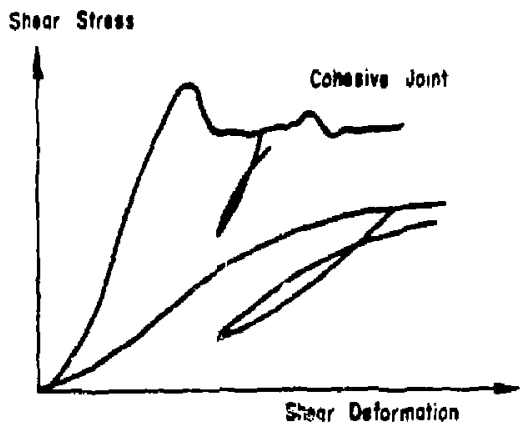

\section{ACTUAL EXPERIMENTAL RESPONSE OF TWO JOINTS}

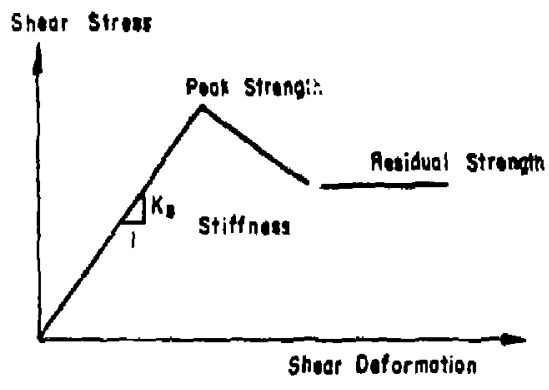

IDEALIZED REPRESENTATION OF JOINT RESPONSE

FIGURE 2-36 Typical shear stress, shear deformation response of joints Source: Agapito et al, 1977. 
No quantitative information was found on joint stiffness, either shear stiffness (Figure 2-35) or normal stiffness (Figure 2-36). Coulson (1970) has performed shear strength testing on artificial surfaces which were cut and sandblasted and lapped with various grades of material. The data shown in Figures 2-37 and 2-38 constitute the data base for basalt at the present time regarding behavior of the joints.

The mechanical, thermal, and thermal-mechanical properties of basalt must be determined both in situ and in the labnratory under carefully controlled conditions so that the input data required for scoping studies and for detailed quantitative evaluations can be made. At the present time, it is felt that the input data required for any significant modeling does not exist. The modelers, however, should be working in close cooperation with the experimentalists in helping to construct the experiments required to provide the input data (See CHAPTER I - GRANITES for a more comprehensive discussion of the modelers role.) 

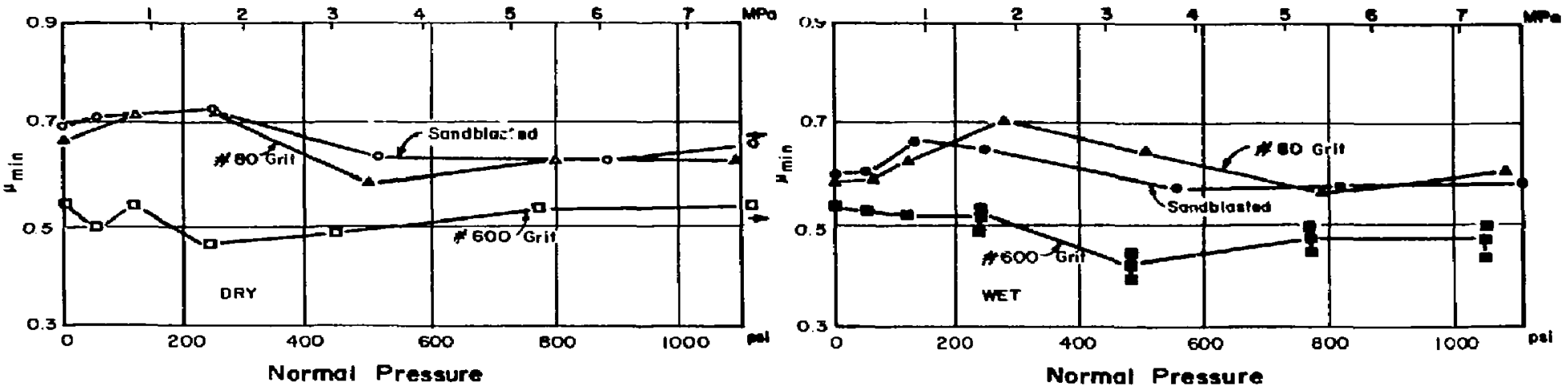

FIGURE $2-37$

liinlmum coefflcienta of frictior :ersus normal

pressure for lower granite basalt

Source: Coulson, 1970 
No quantitative information was found on joint stiffness, either shear stiffness (Figtre 2-35) or normal stiffness (Figure 2-:5). Coulson (1970) has performed shear strength testing on artificial surfaces which were cut and sandblasted and lapped with various grades of material. The data shown in Figures 2-37 and 2-38 constitute the data base for basalt at the present time regarding behavior of the joints.

The machanical, thermal, and thermal-mechanical properties of basalt must be determined both in situ and in the laboratory under carefully controlled conditions so that the input data required for scoping studies and for detailed quantitative evaluations can be made. At the present time, it is. felt that the input data required for any significant modeling does not exist. The modelers, however, should be working in close cooperation with the experimentalists in helping to construct the experiments required to provide the input data (See CHAPTER I - GRANITES for a more comprehensive discussion of the modelers role.) 

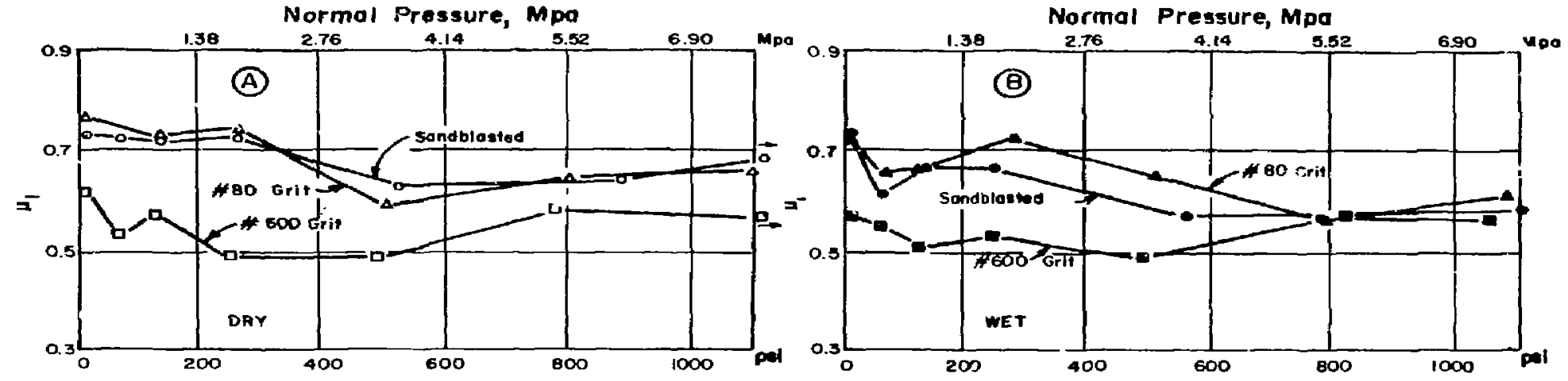

雚
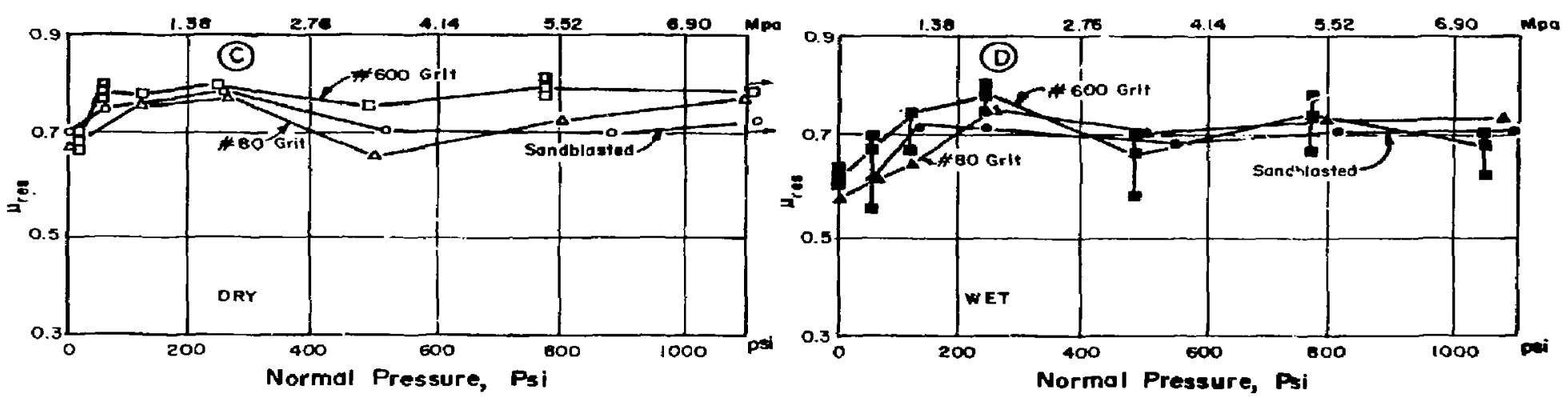

FIGURE $2-38$

Inftial residual coefficlents of friction versus normal pressure for lower granite basalt

Soldrce: Coulson, 1970 . 


\subsection{REFTKENC'S}

Agapito, I.F.T., Hardy, M.P. and D.R. St. Laurent, 1977, Geo-Engineering revieh and proposed program outline fir the structural design of a radioactive waste repositc $y$ in Columbia River Basalt, Rockwell International, RH:$S T-6$.

Atlantic Richfield Hanford Company, November 1976, Preliminary feasibility study on storage on radioactive wastes in Columbia River Basalts, ARH-ST-137.

Birch, F. and H. Clark, August 1940, The thermal conductivity of rocks and its dependence upon temperature and composition, "American Juurnal of Science."

Birch F., Schairer, J.F., and H.C. Spencer, 1942, dandbook of Physical Constants, Geological Society of America, Memoir 36.

Board, M.P., and J.F. Marron, Decernber 1977, Near surface test facility test plan, Unpublished report on contract EY-77-C-06-1030.

Bolz, R.E, and G.L. "ve, 1942, Handbook of Tables for Applied Physical - stants, Geological Society of America, Memoir:.:

Clark, S.P., 1966, Handbook of Physical Constints, Geological Society of America, Memoir 97.

Coulson, J.H., 1970, The effects of surface roughness on the shear strength of joints in rock, Corps of Engineers, NTIS AD714244.

Deere, D.U., and R.P. Miller, December 1966, Engineering classi.́ication and incex properties for intact rock, Air Force Weapons Lab Tech. Report, AFWL-TR-65-115.

Deju, R.A., November 26, 1976, Feasibility of storing radioactive wastes in Columbia River Basalts, ARH-SA281, Atlantic Richfield Hanferd Company.

Deju, R.A., Feasibility of Storing Radioactive Wastes in Columbia River Basalts, Storage in Excavated Rock Caverns (Proceedings of Rock store 77), stockholm, Sweden, 1977, v. 3.

Deju, R.A., April 1977, A plan to study the environmental factors needed to estublish the feasibility of storing radioactive wastes in Columbia River Basalts, ARH-ST152, Atlantic Richfield Hanford Company, Richland, Washington. 
Deju, R.A., et al, September 1977, Environmental factors needed to establish the geotechnical feasibility of storing radioactive wastes in Columbia River Basalts, RHO-ST- 8.

Deju, R.A., and R.E. Gephart, November 1, 1976, Preliminary feasibility study on storage of radioactive wastes in Columbia River Basalts, ARH-ST-137, V. 1, Atlantic Richfield Hanford Company, Richland, Washington.

Duval, W.I., Miller, R.J., and F.D. Wang, May 1978, Preliminary report on physical and thermal properties of basalt: drill hole DC-10, Pomona Flow-Gable Mountain, RHO-BWI-C-II.

Ekren, E.B., 1968, Geologic Setting of Nevada Test Site and Nellis Air Force Range, in Nevada Test Site, Geological Society of America, Memoir 110 .

Griggs, D.T., Turner, F.j., and H.C. Heard, Deformation of rocks at $500 \mathrm{C}$ to $800 \mathrm{C}$, Rock Deformation, Griggs and Handin, Geological Society of America, Memoir 79.

Hardy, M.P., and G. Hocking, 1977, Numerical Modelling of rock stresses within a basaltic nuclear waste repository: phase II - parametric design studies, reported submitted to Rockwell Hanford Operations, EY-77-C-061030.

Hoek, E., and E.T. Brown, Underground Excavation Eryineering, The Institution of Mining and Metallurgy, Lordon, In Press.

Iida, K., Wada, T., Aida, Y., and R. Schichi, 1960, Measurements of creep in igneous rocks, "Journal of Earth Sciences," Nagoya liniversity.

Kreck, W.W., Henderson, F.A., and K.E. Jhelmstad, 1974, A standard rock suite for rapid excavation research, U.S. Bureau of Mines, R.I. 7865 .

Irupka, M.C., 1974, Selected physico-chemical properties of basaltic rocks, liquids and glasses, LA-5540-MC, LOS Alamos Scientific Laboratory, Los Alamos, Now Mexico.

Krumer, A., 1968, The Effect of Stress Rate and Temperature on t..e Strength of Basalt and Granite, Geoptysics, 33, (3).

Lee, W.H., and Morris, R.H., 1968, Preliminary Lithologic Log of Drill Hole UAE-1 from 5000 to 7000 feet, Anchitaka Island, Alaska, USGS 474-47, Clearinghouse, springfielo, Virginia.

Lehnhoff, T.F., and J.D. Scheller, 1975, The influence of temperature dependent properties on thermal rock fragmentation, IJRM. 
Lindholm, U.S., Yeakley, L.M., and Nagy, A., 1974, The dynamic strength and fracture properties of Dresser Basalt, International Journal of Rock Mechanics and Mining sciences, and Geomechanics abstracts, V. II, pp. $181-191$.

Lindner, E.N., and J.A. Halpern, 1977, Insitu stress: an analysis, 18th U.S. symposium on rock mechanics.

Lindroth, D.P., and W.G. Krawza, Heat content and specific heat of six rock types at temperature to $1000 \mathrm{C}$, USBM RI 7503 .

Lutton, R.J., 1968, Comparison of Strengths of Dense and Vesicular Types of Basalt. "Bull. Assn. Eng. Geol.," V. 5, No. 1 .

Moroveili, R.L., and K.F. Veith, 1965, Thermal conductivity of rock: measured by the transit line source method, U.S. Bureau of Mines, R.I. 6604.

Munjal, P., and I. Fatt, December 24, 1966, Thermal anisotropy in rocks, Nature, v. 212.

Murrell, S.A.F., and S. Chakravarty, 1973, Some new rheological experiments on igneous rocks at temperatures of up to $1120 \mathrm{C}$. Journale of Geophysical Research, Abstracts, Soc. 34 .

Nafe, J.D., and C.I. Drake, 1968, Physical properties of rocks of basaltic composition, Basalts, Hess and polcervaart.

Nafe, J.E., and C.L. Drake, 1958, Physical properties of rocks of basaltic composition, basalts, The Poldervaart Treatise on Rocks of Basaltic Composition, edited by H.H. Hess and $\bar{A}$. Poldervaart, Interscience Publishers, v. 2, pp. 483-502.

Nieble, C., Midea, N.F., Fujimura, F., and S.B. Neto, 1974, Shear strength of typical features of basaltic rock masses - Parana Basin, Brazil, proceedings of the Third International Congress on Rock Mech., Denver, Colorado.

Office of Nuclear Waste Isolation, 1978, Technical support for GEIS: Radioactive waste isolation in geologic formations: V. 7-baseline rock properties (basalt), $\mathrm{Y} / \mathrm{OWI} / \mathrm{TM} /-36 / 7$.

Panek, L.A., 1970, Effect of rock fracturing on the modulus as determined by bore hole dilation tests, proceedings of the Second International Congress on Rock Mech., Belgrade. 
Parsons, Brinckerhoff, Quade, and Douglas, Inc., April 1978, Technical support for GEIS, radioactive waste isolation in geologic formations, V.14 - repository preconceptual design studies (basalt), Y-OWI-TM-36-14.

Parsons, Brinckerhoff, Quade and Douglas, Inc., September, 1976, Thermal guidelines for a repository in bedrock, Y-OWI-SUB-76-16504.

Richter, D., and G. Simmons, 1974, Thermal expansion behavior of igneous rocks, International Journal of Rock Mechanics and Mining Sciences, and Geomechanics Abstracts, V. $\frac{\text { 11, pp. }}{403-411}$.

Rodrigues, F.P., "Anisotropy of Granites", 2nd Int. Congress on
Rock Mechanics, Belgrade, 1970

Sandia, 1962, Project Buckboard, 20-ton adn 1/2-ton High Explosive Cratering Experiments in Basalt Rock, final report, August 1962, by Sanida Corporation.

Sellers, J.B., January 1970, Rock testing report, teledyne terrametrics.

Sharp, R.R., 1372, A Geological Engineering Evaluation of an Underground Nuclear Test Site, PhD. thesis, University of Arizona.

Stowe, R., 1969, Strength and Deformation Properties of Granite, Basalt, Limestone, and Tuff at Various Loading Rates, U.S. Army Eng. Waterways Exp. Station, Misc. Paper C-69-1.

Thirumalai, K., 1970, Rock fragmentation by creating a thermal inclusion with dielectric heating, U.S. Bureau of Mines, R.I. 7424 .

Wingquist, C.F., 1970, elastic modulii of rock at elevated temperatures, U.S. Bureau of Mines, R.I. 7269.

Wuerker, R.G., 1956, Annotated tables of strength and elastic properties of rock, Trans. SPE (AIME).

Union Carbide Corporation/Office of Waste Isolation, Nuclear Division, April 1978, Commercial Waste Forms, Packaging and Projections for Preconceptual Repository Design

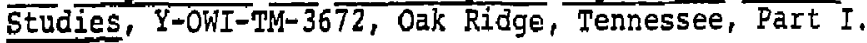

U.S. Army Corps of Engineers, 1965, Project Longshot, Amchitka Island, Alaska, Geologic and hydrologic investigations (Phase I), U.S. Army Eng. District, Anchorage.

U.S. Bureau of Reclamation, January 1976, Corstruction and roundation materials test data for bacon siphon and tunnel-second unit, DC-7206. 
HYDROLOGY OF BASALT 


\subsection{INTRODUCTION TO HYDROLOGY OF BASALT}

Ground water migration through a basalt sequence occurs as it flows through both porous intergranular and non-porous fractured media. The mechanics of flow through butin of these media was presented in sections 1.18 through 1.22 . Drawing upon this background, this section presents a sumary of the physical characteristics of basalt flows and discusses porosity, permeability and ground water flow regimes through basalt sequences. Special hydrologic features of basalts found on the Columbia Plateau, Snake River Plain and Modac Plateau are then discussed. 


\subsection{PHYSICAL CHARACTERISTICS OF BASALT FLOWS}

\section{Lava Forms}

The subareal lava flows issuing from fissure eruptions in the American northwest are predominantly of two types, pahoehoe and aa. These two forms of lava are distinquished by various flow features controlled by the viscosity and degree of agitation in the extruded lava mass. Most flows issue as pahoehoe, and as viscosity declines downslope change into aa.

Pahoehoe flows are characterized by a rolling, billewy or "ropy" surface. This feature results from the deformation and folding of the thin, cooled lava surface by deeper flowing lavas. Vesicles, resulting from the release of gas by the lava, are abundant in pahoehoe flows. Spherical or nearly spherical vesicules may fully permeate thin flows, while in thicker flows vesicles concentrate near the top of the flow. In some cases, vesicles may also be found in a chilled layer near the base $c$ flow.

In contrast to the relatively smooth, undulating surface of a pahoehoe flow, aa flows are rough, spiny, fragmented, and blocky. The surface is scoriaceous, the top and margins of the flow being covered with clinker. Occasionally, a layer of clinker may also be found on the lower surface of the flow; however, in the Columbia River and Cascade region, flows generally lack this feature. Ae flows are generally much less vesicular than pahoehoe flows. Vesicularity 
may reach $50 \%$ in some flows, howerer, normally is less than 30\% (MacDonald, 1967). Those vesi:les present are generally less than $2 \mathrm{~cm}$. in diameter and nonspherical.

A third type of subareal flow, block lavas, are rarely found in the northwest. Block flows are generally characteristic of siliceous lavas rather than lavas of basaltic composition such as those of the Columbia Plateau region.

Since lavas were extruded in some areas of the northwest into shallow seas or fresh water lakes, subaqueous flows are also of some interest. The predominant subaqueous form is pillow lavas. These flows consist of stacked elipsoidal bodies of lava generally ranging $10 \mathrm{~cm}$, to $7 \mathrm{~m}$, in diameter. "Pillows" may be compactly molded together or separated partly or wholely by detrital materials. Most have glassy skins and are radially fractured.

\section{Joints And Cooling Features}

As a basalt flow cools, shrinkage of the lava causes the development of vertical tension fractures or joints. In a massive flow these joints form in regular patterns. Thin flows are normally characterized by rectangular or irregular polygonal joint configurations in the horizontal plane. Thicker flows exhibit more uniform hexagonal systems of joints in the $x-y$ plane, resulting in the formation of vertically standing columar structures. Holmes (1965) explains the formation of "columnar" joints: 

"When a hot homogeneous rock cools uniformly against a plane suriace, the contraction is equally developed in all directions throughout the surface. This is mechanically the same as if the contraction acted towards each of a series of equally spaced centres. Such centres (C. 1,2, 3 , etc. in Figure 2-39a) form the corrers of equilateral triangles, and theoretically, this is the only possible arrangement. At the moment of rupture the distance between any given centre $C$ and those nearest to it is such that the contraction along lines such as $\mathrm{C}-1$ is just sufficient to overcome the tensile strength of the rock. A tension crack then forms halfway between $\mathrm{C}$ and 1 and at right angles to the line $\mathrm{C}-1$. As each centre is surrounded by six others (1-6 in Figure 2-39a), the resultant system of cracks is hexagonal. Once a crack occurs somewhere in the cooling layer the centres are definitely localized, and a repeated pattern of hexagonal cracks spreads almost simultaneously throughout the layer (Figure 2-39b). As cooling proceeds into the sheet of rock the cracks grow inward at right angles to the cooling surface and so divide the body into a system of hexagonal columns."

The description of jointing presented by Holms, although generally accepted in principle, is somewhat oversimplified. A diagramatic cross section of the Pomona flow of the Columbia River Basalt, Figure 2-40, shows jointing to be somewhat more complex. Ryan (1974) suggests the Pamona flow consists of 7 relatively distinct vertically distributed zones. The uppermost zone, Zone $I$, which he identifies as the flow top, consists of a 20 to $30 \mathrm{~cm}$. Layer of weathered scoriaceous lava and rubble underlain by a 2-3 m. thick zone of high vesicularity. Vesicles in this zone range from 5 to $25 \mathrm{~mm}$. in diameter.

Zone II is termed the upper colonnade. This region contains vertically standing hexagonal columns of 2-3 $\mathrm{m}$. In diameter with face width of 1-2 $\mathrm{m}$. and heights of 4-8 $\mathrm{m}$. These columns, the largest in the flow unit, often bear faces 


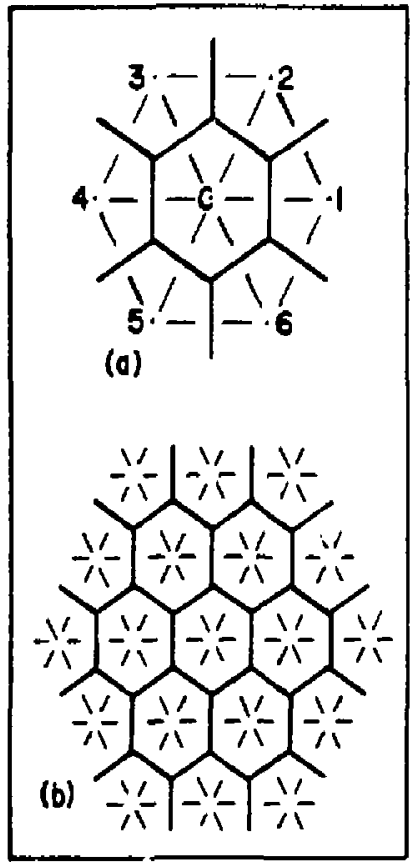

Figure 2-39 Formation of "ideal" hexagonal fracture pattern due. to uniform contraction toward evenly-spaced centers. Source: Ryan (1974) 


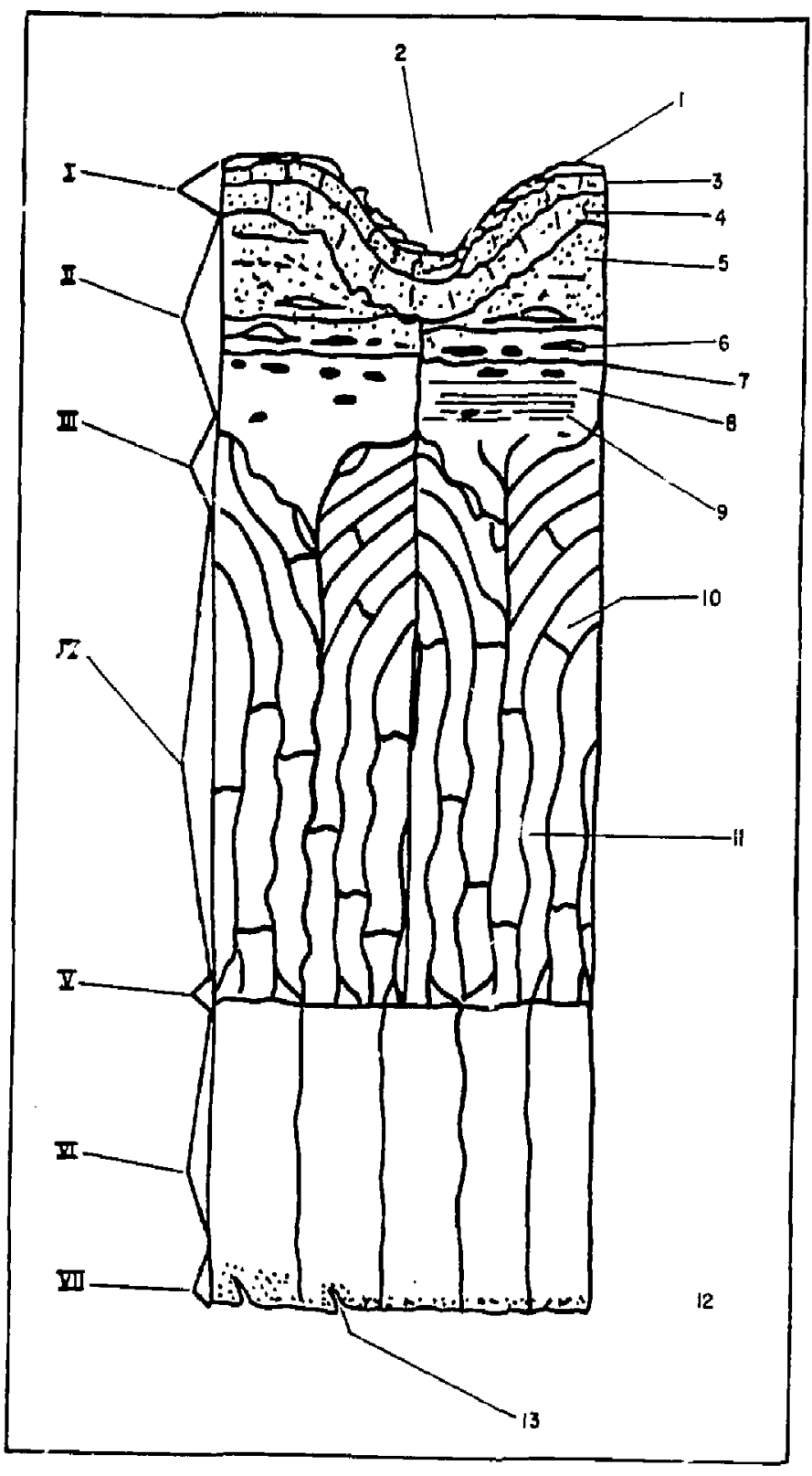

Figure 2-40 Stmplified cross section of the Pomona flow unit:

(1) Flow top; (II) Upper colonnade; (III) Upper transition zone; (IV) Entablature; (V) Lower transition zone; (VI) Lower colonnade; (VII) Flow base. Smaller atructures are: (1) Pahoehoe or Ropy lava; (2) Localized sags in the flow top (not to scale); (3) Blocky Scor 1a; (4) Small oub-vertical jointing confined to flow top; (5) Transition from spherical vessiteles to elongate ones; (6) Large elliptical vessicies;

(7) Cross fractures; (8) Upper colonnade column;

(9) Horizontal ridges; (10) Cross fractures;

(11) Undulating fracture surfaces; (12) Vessicular rone; (13) Spiracles. Source: Ryun, 1974 
which are non-planer and appear warped or twisted. Some cross fracturing is evident in this zone and is often found to coincide with eliptical vesicles having horizontal major axis.

Underlying the upper colonnade is an upper transition zone, Zone III, wherein the size of both colum faces and diameters are rapidly reduced. Within this 3-5 $\mathrm{m}$. thick zone, the large columns of the upper colonnade are subdivided into smaller and smaller polygons. The large colums of the upper colonnade are transformed into bundles of smaller columns which blend to form the next lower zone known as the entablature.

The entablature, zone IV, is characterized by slender, subparallel colums 15 to $20 \mathrm{~m}$. in height. The joints bounding the columns of zone II often extend into the entablature grouping columns in this unit into "megacolumns". Individual columns within the megacolum are often cross fractured, although fractures among colums are not generally coincident.

Below the entablature is a lower transition zone, zone V, about $1 \mathrm{~m}$. In thickness. This zone marks the abrupt boundary between the entablature and the lower colonnade. The lower colonnade, Zone VI, consists of columns 6 to $7 \mathrm{~m}$. in length and 1 to $1.5 \mathrm{~m}$. in diameter. Symmetry among hexagonal column is generally most evident in the lower colonnade. 
The lowermost zone in the Pamona flow, Zone VII, is identified by Ryan as the flow base. This region consists of small vesicles and spiracls which result from gases formed along the lower contact migrating upward into the lava. The flow base, where present, is 20 to $30 \mathrm{~cm}$. thick.

Not all lava flows exhibit ail classical features associated with columnar jointing as described by Ryan in the Pamona flow. However, most are quite similar in general configuration.

\section{Flow Geonetrics}

Individual flows are topographically controlled. In regions of low relief, viscous lavas generally fill valleys or flow onto plains and solidify, leaving a basalt mass with a roughly convex cross section perpendicular to the direction of flow. Lavas of lower viscosity or those flowing in areas with greater topographic relief often result in basaltic masses with a concave cross secticn. This feature, results as cooling, is initiated along the margins of a flow while the core remains mobile. In many of the larger flows of the Columbia Plateau, the convex or concave shape is apparent only in terminating tongues of the flow. Because of the large quantity of lava extruded and great areas covered, the central portions of the flow may appear nearly horizontal. 


\section{Interbeds}

If the deeper parts of the Columbia Plateau there are in excess of fifty individually identifiable Miocene lava flows, many in excess of $10 \mathrm{~m}$. in thichness. Between flow event the swifaces of the exposed flows were exposed to weathering $<$ id erosion. Fluvial silts, sands and gravels, as well as lacustrine silts and clays were deposited in some regions forming interbeds between the flows. Strata consisting of tuff and volcanic ash can also be found interdispersed with the flows.

\section{Tectonic Features}

As volcanism proceeded, tectonic activity caused fauling and folding of previously deposited sequences. Faults and structural exis often are found to control ground water flow through the basaltic equifer. Also of some importance are reginnal joint systems. These regional joint and fracture systems may be mapped throughout most of the area of deposition of the northwest basalts; however, their relation to lava emplacement and later tectonic activity is not well understood 


\subsection{POROSITY, PERMEABILITY AND GROUND WATER FLOW REGIMES}

Variations in permeability and porosity anong flows - .a even within flows is so great that the assignment of average values of $k$ and $\theta$ for a generic basalt would be both arbitrary and misleading, However, some generalizations concerning ground water flow through a basalt may be developed without assigning definitive or "representative" values for hydrologic parameters.

Permeability of basaltic sequences is highly anisotropic. Horizontal components of permeability generally greatly exceed vertical components. In any given flow, permeabilities are generally much greater near the upper and lower margins of the flow than in its center. While jointing in the entablature and lower colonnade does contribute to ground water flow, permeabilities of Zones I, II, and VII of the flow unit are generally tuch higher. Principal flow regimes within a basalt sequence may be categorized:

1. Interflow regions - interfaces between flows, or the interfaces between flows and interbeds, provide one of the most permeable regimes for flow within the basaltic sequence. Rubble zones, scoria, weathered surfaces, fracture-connected vesicles and interflow voids in Zones I and II on the upper surface of a flow and in zone vII of an overlying flow of ten provide a highly pervious medium in which ground water migration may occur. 
2. Interbeds - Interbeds, or sediments deposited between volcanic events, are highly varied in character. Fluvial sands and gravels as well as some sandy lacustrine deposits compose highly permeable zones between lava flows. However, interbeds composed of lacustrine silts and clays bear a much lower permeability and often act as aquitards or aquicludes in the sequence.

3. Joints - Joints observed in flows on the Columbia Plateau range from less than a centimeter to several meters in width. These joints are the principal means of vertical movement of ground water through a basalt sequence and are also often an important means of horizontal flow.

4. Other features - Lava tubes, breccia pipes and fault zones all form localized features which can dominate ground water flow. However, the frequency of occurrence of these features is sufficiently low in the northwest basalts as to minimize their importance when discussing regional flow. A waste repository will probably not be sited in the vicinity of highly permeable ground water conduits such as these.

Ranges of ralues of hydraulic conductivity measured in various basalts of the northwest United States are sumarized on Figure 2-41. Specific permeability data are presented in Sections 2.20 through 2.22 and are summarized in Appendix A. 
FIGURE 2-4I

HYDRAULIC CONDUCTIVITY DATA FROM BASALTS IN THE NORTHWुEST UNTTED STATES

\begin{tabular}{l}
$n$ \\
1 \\
\multirow{\infty}{\omega}{}
\end{tabular}

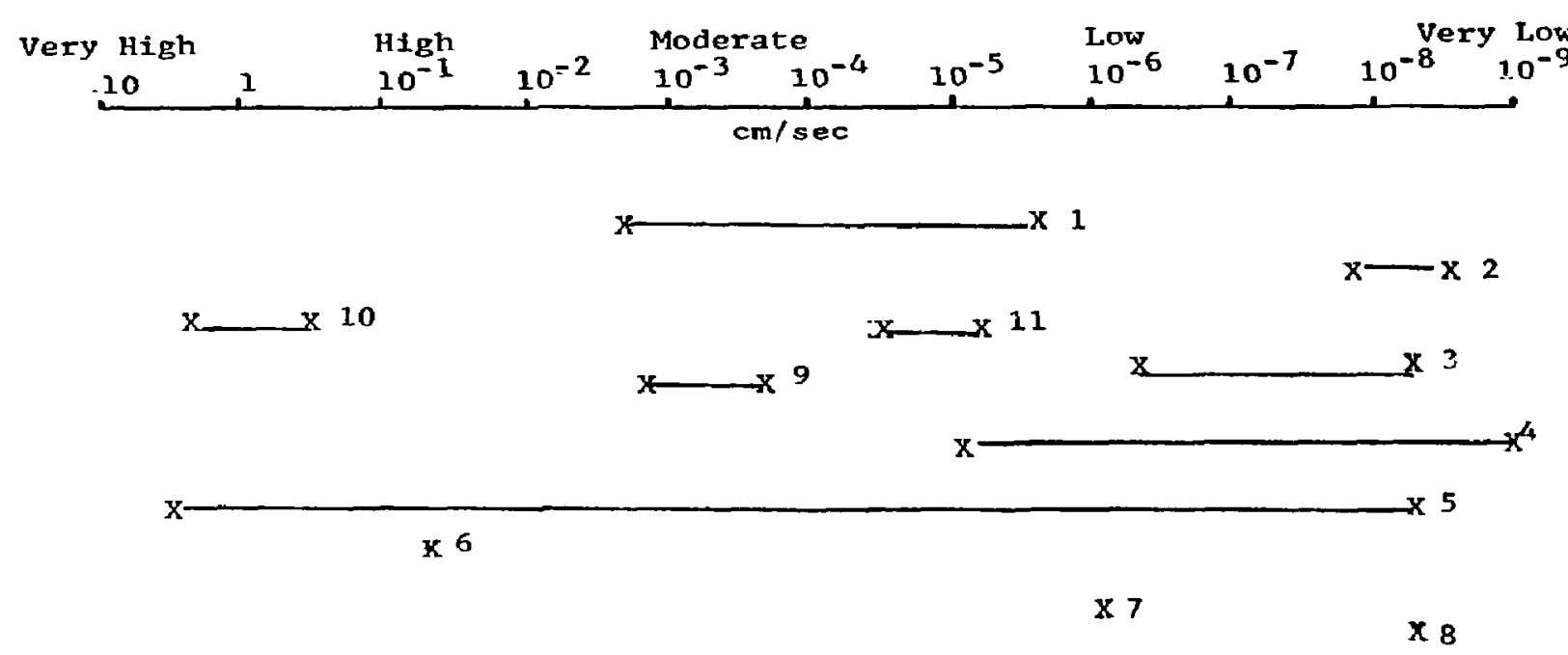


SOURCES OF DATA

AREA

1. Columbia Rjver Besalt

2. Columbia River Basalt

3. Columbia River Basalt

4. Hypothetical Case

5. Snake River plain

6. Dalles, Oregon

7. Columbia River Basalt

B. Columbia River Basalt

9. Colunbia River Basalt

10. Columbia River Basalt

11. Columbia River Basalt

Figure 2-41 (Con't) Sources

\section{TYPE \& SOURCE}

Field, Lo Sála \& Others, 1970

La Sala \& Others, 1972 ( $\mathrm{lab}$ data)

ONWI, 1978 (v7)

ONWI, 1978 (v21)

Idealized, Skibitzke and Costa, 1962

Foxworthy and Bryant, 1967

F: ectured, Hanford, Co., 1976

Dens?, Hanford, Co., 1976

Eddy, 1969

Sumpers \& Leju, 1976 (highest values)

Sudmers \& Deju, 1976 (dowest values) 


\subsection{IYDROLOGIC FLATURES OF THE COLUMBIA RIVER BASAIT}

\section{Origin}

The Columbia River basalt, as located and discussed in Section 2.7, encompasses an area in excess of 150,000 sq. kilometers in southeast Washington, northeast Oregon and western Idaho. During a period extending from the middle to late Miocene, this region was subsiding while fissure eruptions repeatedly poured lava into the developing basin.

By the late Miocene, the basin encompassed an area bounded by Mesozoic granites of the Okanogan highlands on the north, the preCambrian to Mesozoic sequences of the Rocky Mountains to the east and the folded tertiary sediments of the Cascales and Blue Mountains to the west and south (Deju et al, 1977). As volcanism declined in the late tertiary, a series of west to northwest trending anticlinal ridges formed across the subsiding basin. Broad synslines formed between these ridges creating the Umatilla, Pasco, Quincy, and several smaller structural basins.

\section{Stratigraphy of the Pasco Basin}

The Pasco basin, located on Figure 2-42, is sicuated near the depocenter of the regional subsidence. The minimum thickness of the Miocene basalt sequence in the basin is estimated to be $1500 \mathrm{~m}$. (Meyers, 1973)(Meyers and Brown, 1973) (Brown and Ledgewood, 1973). 

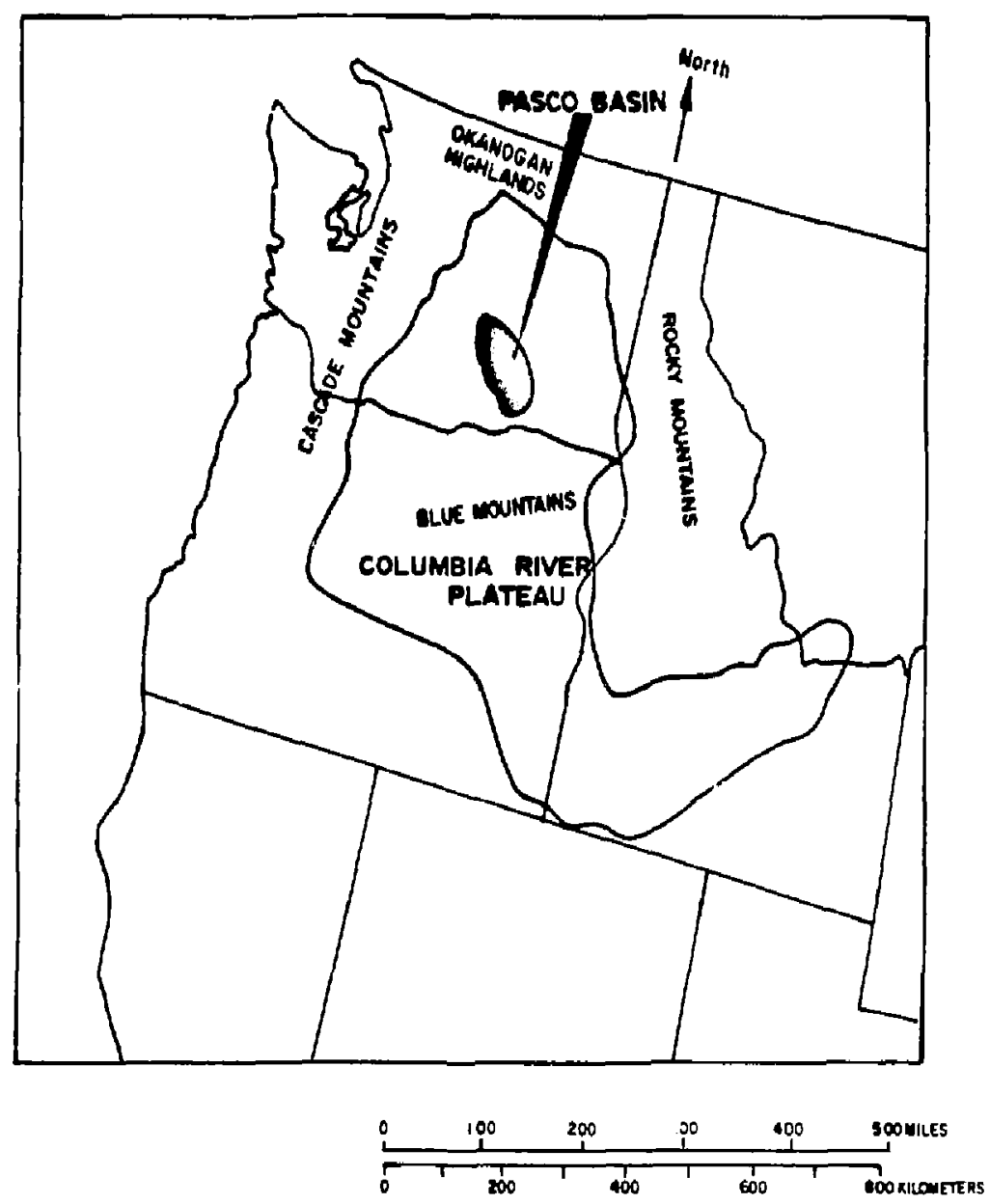

Figure 2-42 The Columbia Rlver Plateau. Source: NWTSP (1976) 
The waximum thickness of this sequence is not precisely known; however, where these flows have been penetrated, they are found to overlie older basalts of Oligocene and Eocene age.

There are 5 principal accumulations of flows in the Columbia River Group of the Pasco Basin. The lower two units are the Picture Gorge Basalt and Imaha Basalt. The upper 3 formations, identified on the stratigraphic colum, Figure 2-43, are the Grande Ronde (Lower Yakima), Wanapum (Middle Yakima) and Saddle Mountains (Upper Yakima). Each of these formations contains numerous individual flows, many interbedded with sandstones, siltstones, tuff or diatomite. The geographic relationships of these flows are identified on Figures 2-44 through 2-46. Detailed physical and chemical descriptions of individual flows may be found in a report prepared for the National Waste Terminal Storage Program (1976).

Overlying the upper basalts in the basin is the Ringold formation, a series of early Pleistocene fluvial silts, sands and gravels with interbedded clays in the lower portions cf the formation. The youngest rocks in the basin are late Pleistocene glaciofluvial sediments, ash beds and eolian deposits which overlie the Ringold Formation. 


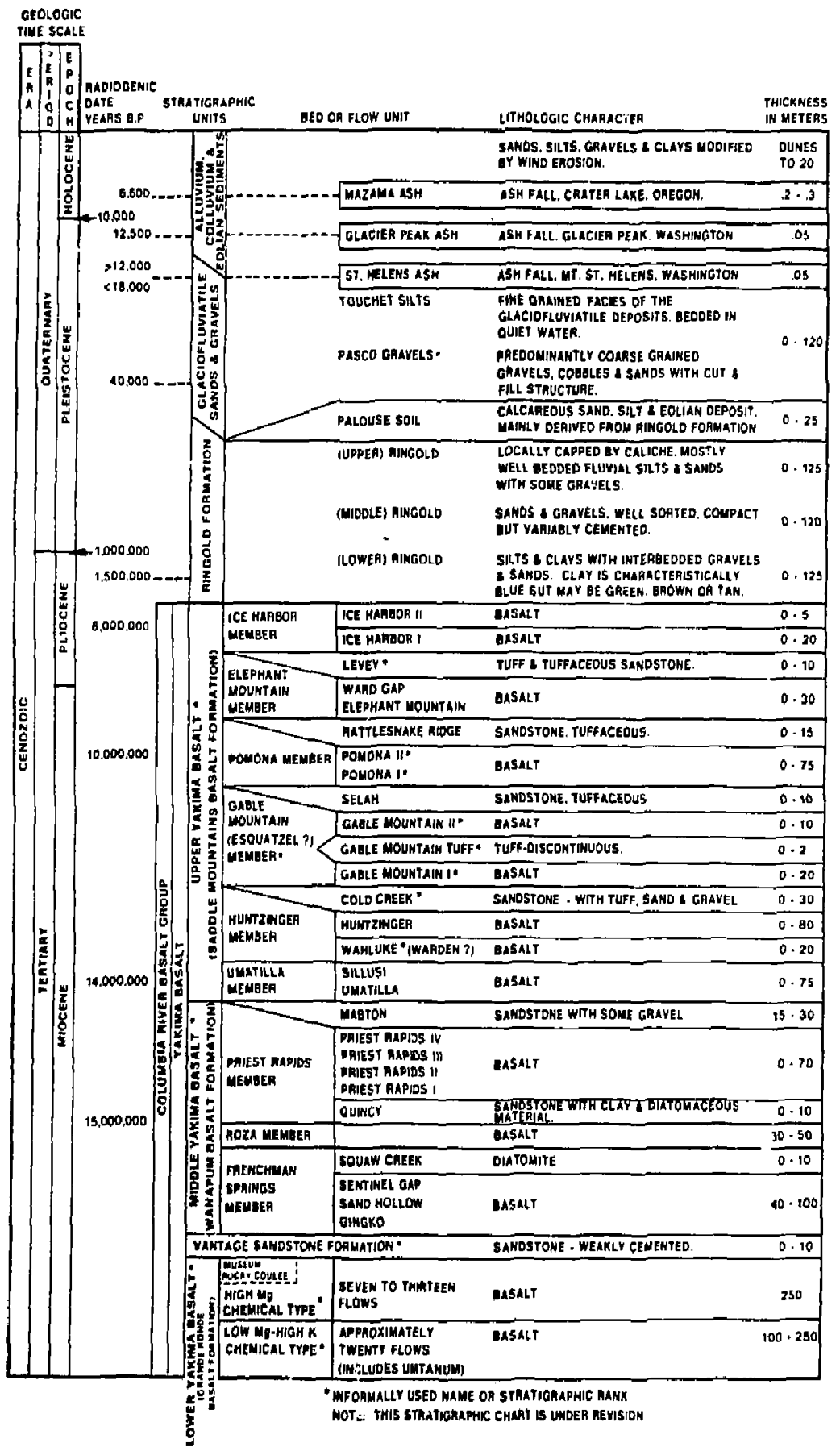

Figure 2-43 Stratigraphy of the Pasco Basin. Source: NWTSP (1976) 


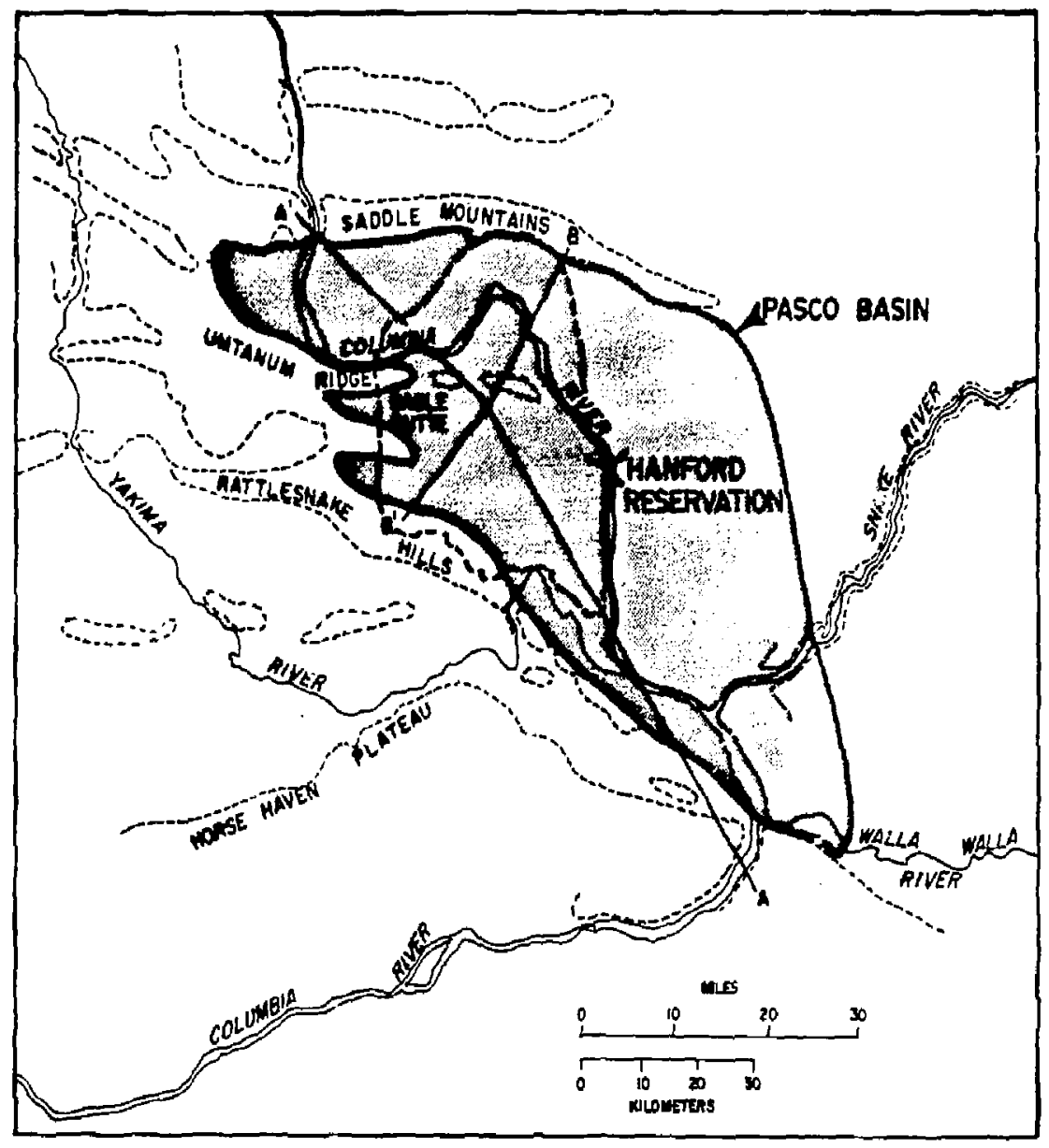

Figure 2-44 Geography of Pasco Basin. Source: NWTSP (1976) 


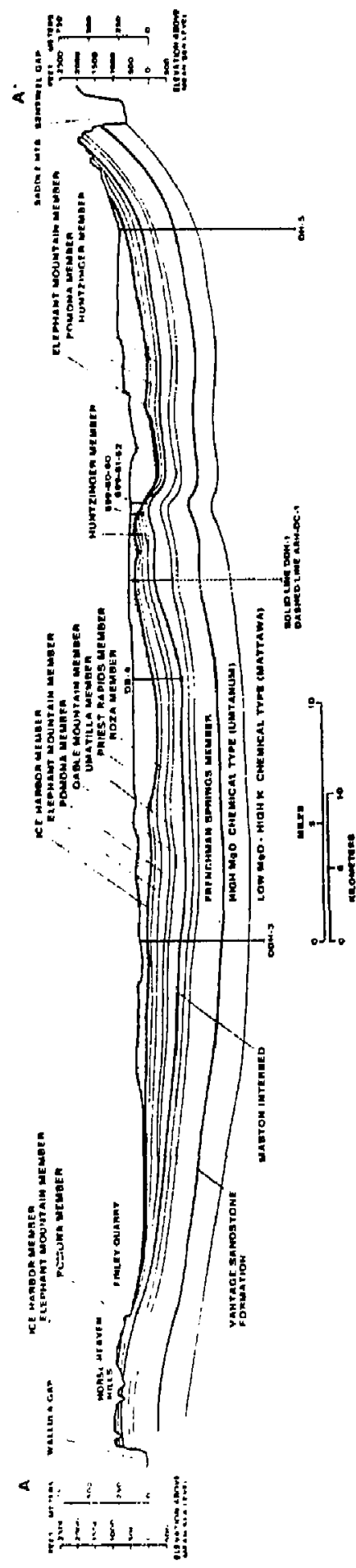

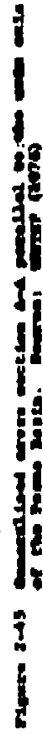




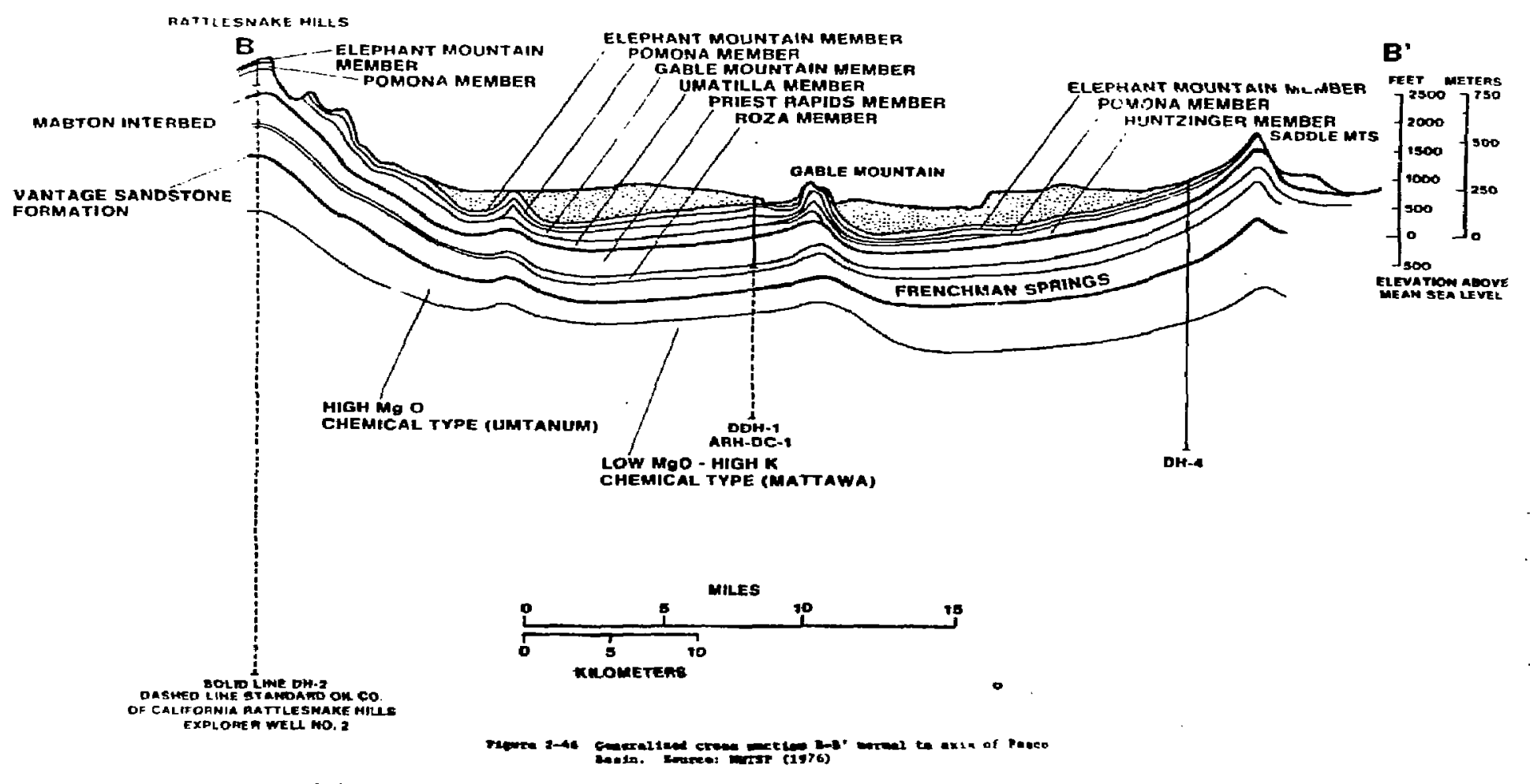




\section{Hydrology of the Pasco Basin Sequence}

The Pasco basin has often been suggested as a potential site for a deef repository because it appears to possess the smallest quantity of usable ground water per unit surface area of any of the structural basins (Deju et al, 1977). The basin has numerous thin beds of clay-rich sediment and saprolite which were deposited belween the outpourage of Columbia River Basalt. This material has since plugged pore and fracture spaces, reducing the rate of ground water movement and hydraulically separating individual interflow zones. Pumping data from the Columbia River Basalt within the Pasco Basin show that no large amounts of water have been obtained. The basalts themselves offer zones as thick as $200 \mathrm{~m}$. that are fully dry (Deju, 1977).

Since the siting of the Hanford facility in the Pasco basin, more hydrologic data on deep rock units have been developed on this area than on most of the remainder of the plateau. Testing of the deep basalts at Hanford was begun in 1969 with the construction of well $A R H-D C-1$. Since then, several more wells have been constructed and additional wells proposed (Apps et ai, 1978, 1979). The results of the tests conducted on DC-series wells at Hanford comprise a large portion of the geologic and hydrologic data available on the basin and the deep basalts of the Plateau in general. 
At Hanford an unconfined aguifer overlies the basalts. This aquifer consists of the basal portions of the glaciofluvial sediments and extends downward to the clay layners at the base of the Ringold formation. These layers act as an effective aquitard, confining waters in lower formations. A large body of data is available on the shallow sedimentary aquifer. Sumaries of these data are found in the reports of the National Waste Terminal Storage Program (1976) and the Committee on Radioactive Waste Management (1978).

Of principal significance to the deep burial of nuclear waste are the confined aquifers at Hanford. These are composed of the lowermost portion of the Ringold formation and the underlying Columbia River Basalt Group. The general hydrologic characteristics of the stratigraphic sequence at Hanford are summarized in Figure 2-47.

\section{General Characteristics of Ground Water Flow}

Within the sequence of Miocene basalt flows the zones of highest permeability, as determined from packer test of the Hanford test wells, are the interflow zones separating basalt flows. These interflow zones consist of rubble and porous sediments deposited between flow events. The central volume of most basalt flows is quite dense, having very low permeabilities. Fractures, originating from the cooling of the initial mol ten rock or subsequent structural deformation, control the hydraulic interconnection between basalt units. 


\begin{tabular}{|c|c|c|c|c|c|c|c|c|c|}
\hline \multicolumn{3}{|c|}{ GEOLOGIC TIME SCALE } & \multicolumn{5}{|c|}{ GEOLOGIC CHARACTERISTICS } & \multicolumn{2}{|c|}{ HYDAOCEOLOOY } \\
\hline EAn & PEnNoD & EFOEN & 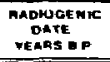 & STRAMIERAPHIC & MTD DE KLOW UNMY & 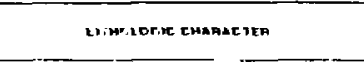 & $\begin{array}{l}\text { Mutekmess } \\
\text { IN WE TERY }\end{array}$ & $\begin{array}{l}\text { HVOHDLOGIC } \\
\text { CHAFACTER }\end{array}$ & SIFER \\
\hline \multirow{13}{*}{ 吾 } & \multirow{8}{*}{ 产 } & \multirow{8}{*}{ 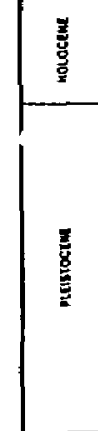 } & \multirow{5}{*}{ 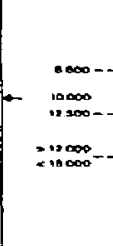 } & \multirow{3}{*}{ 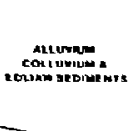 } & \multirow{3}{*}{ 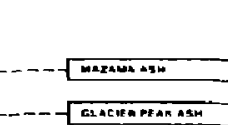 } & \multicolumn{2}{|c|}{ 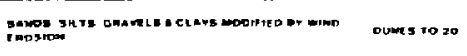 } & \multirow{4}{*}{ 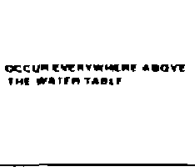 } & \multirow{4}{*}{ onr } \\
\hline & & & & & & 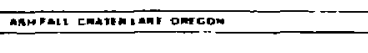 & $\cdots$ & & \\
\hline & & & & & & \multicolumn{2}{|l|}{ 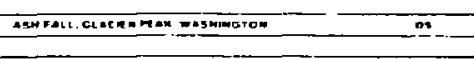 } & & \\
\hline & & & & & ST Matrus Asm & \multicolumn{2}{|l|}{ 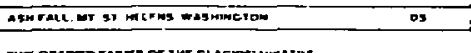 } & & \\
\hline & & & & 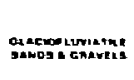 & $\begin{array}{l}\text { Touswet andy } \\
\text { maco andewes }\end{array}$ & \multicolumn{2}{|l|}{ 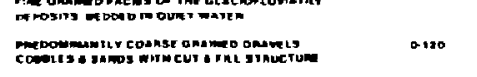 } & 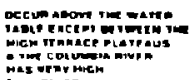 & 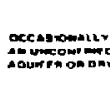 \\
\hline & & & & & malousz so: & 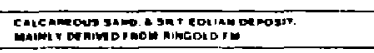 & $0 \cdots$ & 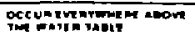 & on \\
\hline & & & & \multirow{4}{*}{$\begin{array}{l}\text { mratoco } \\
\text { pomuation }\end{array}$} & 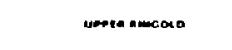 & \multirow{4}{*}{ 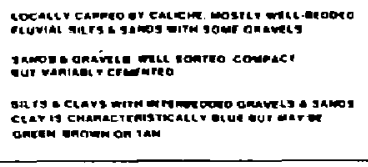 } & \multirow{4}{*}{$a$} & \multirow{4}{*}{ 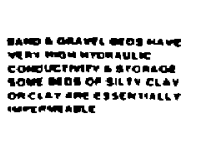 } & \multirow{2}{*}{ nourento } \\
\hline & & & & & mosese amara & & & & \\
\hline & \multirow{5}{*}{ 吝 } & \multirow{3}{*}{ 总 } & 70 & & cances amsono & & & & navercivos \\
\hline & & & & & & & & & \multirow{2}{*}{ 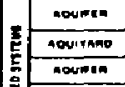 } \\
\hline & & & & \multirow{3}{*}{ 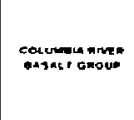 } & 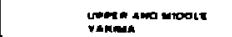 & \multirow{3}{*}{ 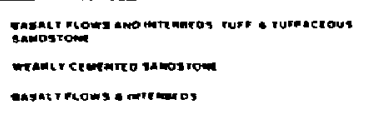 } & \multirow{3}{*}{$\begin{array}{l}0.00 \\
0.10 \\
0.500\end{array}$} & \multirow{3}{*}{ 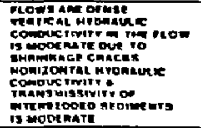 } & \\
\hline & & s & $13000000-$ & & vanuces semastom & & & & Aourreste \\
\hline & & $\$$ & & & comen manes & & & & ncument \\
\hline
\end{tabular}

Figure 2-47 Hydrostatigraphic characteristics of the Pasco Basin. Source: NWTSP (1976) 
In many instances, secondary mineralization has effectively sealed these factures from further ground water movement. Fractures also become tighter the greater their depth of burial. The hydraulic separation of individual waterbearing strata is apparent when the water levels at the top and bottom of some basalt flows are compared (Deju et al, 1977). Figure 2-48 illustrates this confinement of individual zones of higher permeability in the Hanford well ARH-DC-1.

\section{Porosity}

The porosity of rocks in the flood-basalt sequence is not well defined. Porosity within flows is primarily attributable to fracturing and voids in rubble zones at flow margins. If the fractured rock is vesicular, effective porosity is increased by the volume of vesicles that axe parted by fractures. For basalt penetrated by bore hole ARH-DC-l, values of mean porosity were calculated by a commerical logging firm as follows: (a) dense, 1 percent; (b) vesicular, 5 percent; and ( $c$ ' zone of close fractures, 10 percent (Fenix and Scisson, 1969). These estimates were developed using log interpretation principles designed for use in sediments with intergranular porosity. They are not determinations of effective porosity and should only be considered order of magnitude estimates. 


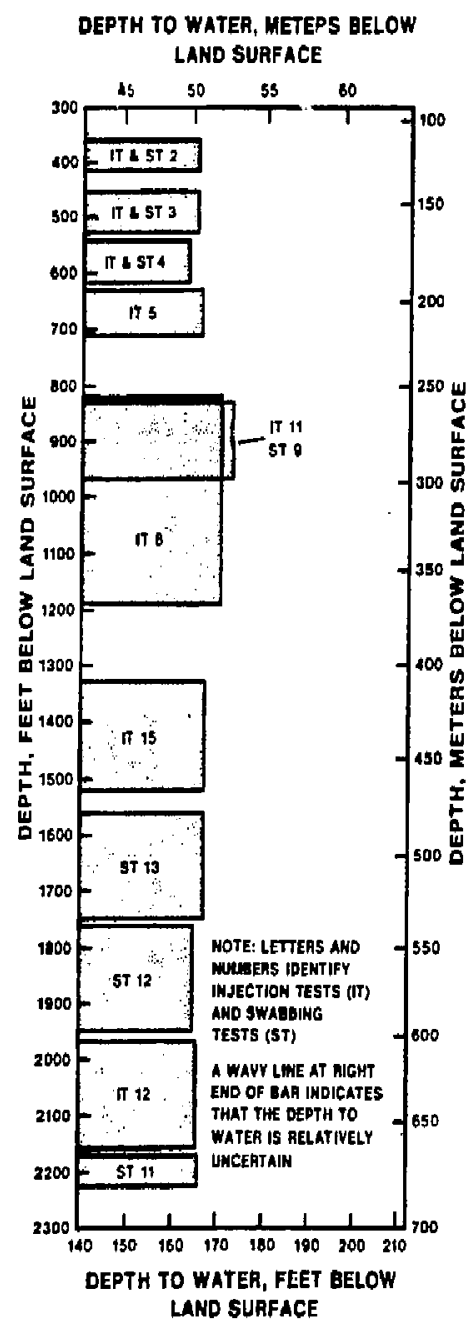

LAND SURFACE
DEPTH TO WATER, METERS BELOW LAND SURFACE

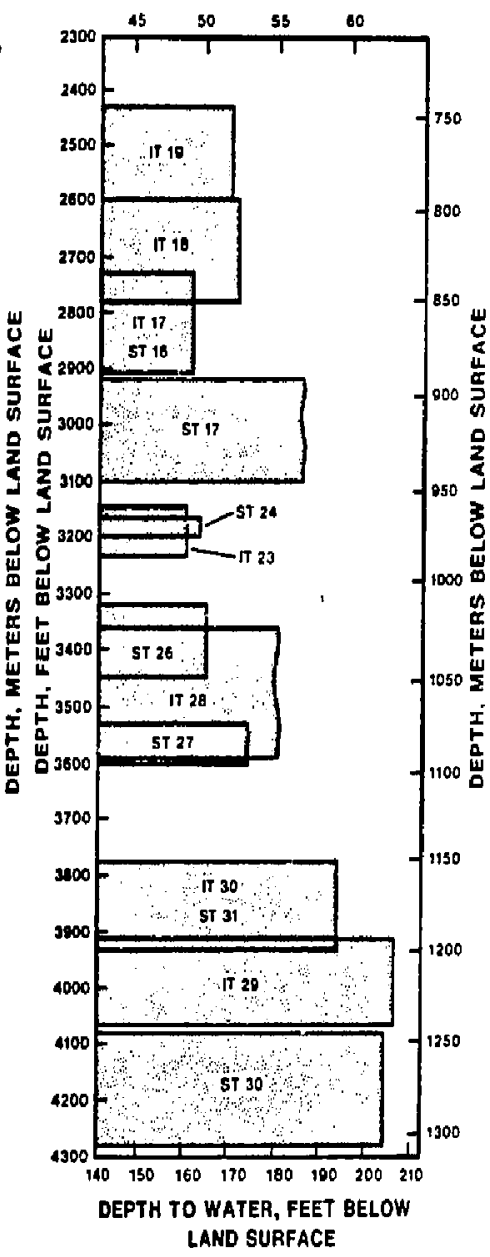

Figure 2-48 Approximate undisturbed ground water head for isolated water-bearing zones in well ARH-DC-1 (1969).

Source: NHTSP (1976) 


\section{Hydraulic Conductivity}

Although there is currently additional well testing work being carried on (Apps et al, 1978, 1979), the greatest bulk of published data on the hyd: aulic conductivity of the basalt sequences in the Pasco basin is derived from tests of well ARH-DC-1. This well penetrated the basalts to a depth of $17^{n} 5 \mathrm{~m}$, and in-hole permeability tests were conducted down to $1305 \mathrm{~m}$. In addition, laboratory permeability tests were conducted on core samples from specific zones of interest.

Those zones identified in packer tests of well ARH-DC-1 as having the highest hydraulic conductivities are identified on Table 2-35. These most permeable zones in the we!. I have hydraulic conductivities ranging from 0.4 to $2.7 \mathrm{~m} /$ day. In the intervening zones, hydraulic conductivities were found to be much lower. The Committee on Radioactive Waste Management (1978), has classified the intervening materials and assigned representative hydraulic conductivities as follows:

a) basalt, dense or with healed joints, about 67 percent of aggregate thickness, mean hydraulic conductivity about $6 \times 10^{-4} \mathrm{~m} /$ day.

b) basalt, vesicular, about 7 percent of aggregate thickness, mean hydraulic conductivity about $9 \times 10^{-4}$ m/day. 
c) basalt, weathered or jointed, about 17 percent of aggregate thickness, hydraulic conductivity about $3 \times 10^{-3} \mathrm{~m} / \mathrm{day} ;$ and

d) tuff or sand, about 9 percent of aggregate thickness, mean hydraulic conductivity about $6 \times 10^{-2} \mathrm{~m} /$ day.

To generalize, all the cited values of conductivity for wateryielding segments are of magnitude $10^{\circ}$; those for the remainder of the confined-water zone grade between magnitudes $10^{-1}$ and $10^{-4}$ $\mathrm{m} /$ day. Evidently, all the basalt in the confined-water zone of the Hanford Reservation must be considered potentially transmissive, in some degree, for dissolved radioactive waste constituents.

In a report prepared for the National Waste Terminal Storage Program (NWTSP, 1976), ranges are presented for the hydraulic properties of both the uppermost confined aquifer, Table 2-36, and various forms of basalt for the Lower Yakima flows, Table 2-37. In the Lower Yakima basalts, in situ measurements of hydraulic conductivity were found to be as low as $10^{-6} \mathrm{~m} /$ day for dense basalt.

Laboratory tests of core taken from well ARH-DC-1 show the hydraulic conductivities to be about 2 orders of magnitude smaller than the average values determined from injection 


\begin{tabular}{|c|c|c|c|}
\hline $\begin{array}{l}\text { DEPTH } \\
\text { (m) }\end{array}$ & $\underset{\mathrm{m} / \mathrm{day}}{\mathrm{K}}$ & ZONE THICKNESS & $\begin{array}{c}\text { DESCRIPTION OF } \\
\text { BEDS }\end{array}$ \\
\hline 147 & & & Sands/Sands \& Clay \\
\hline 181 & & & Sands/Sands \& Clay \\
\hline 226 & 0.4 to 1.0 & $4.6-33 \mathrm{~m}$ & Sands/Sands \& Clay \\
\hline 254 & & & Sands/Sands \& Clay \\
\hline 344 & & & Flow Breccia \\
\hline 626 & 2.7 & 2m & \\
\hline 803 & 0.6 & $3.7 \mathrm{~m}$ & Sands \& Tuff \\
\hline 983 & 2 & $3 \pi$ & Scoria or Breccia \\
\hline 1210 & .5 & $15 \mathrm{~m}$ & Fractured Basalt \\
\hline
\end{tabular}

TABLE 2-35 Principal zones of high hydraulic conductivity Well ARH-DC-1

Source: CRWM (1978) 
Hydraulic

NeI1 Number

LOWER RINGOLD

\section{9-84-35P}

$699-24-1 P$

- 699-S11-EI2

699-20-E12P

\section{Mean}

Range

RATTLESNAKE RIDGE

$$
\begin{array}{r}
199-83-2 P \\
199-44-2 \\
699-14-E 69 \\
\text { Mean } \\
\text { Range }
\end{array}
$$

\section{MAETON}

DH-B Range

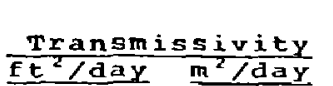

\begin{tabular}{l} 
Cond \\
\hline Et/dax \\
0.11 \\
5 \\
0.5 \\
7 \\
3 \\
$0.11-7$
\end{tabular}

-

$\begin{array}{cc}4 & 0.4 \\ 90 & 8.3 \\ 40 & 3.7 \\ 350 & 32 \\ 120 & 11 \\ 4-350 & 0.4-32\end{array}$

$\begin{array}{ccc}3.5 & 0.3 & 0.25 \\ 3 & 0.3 & 0.3 \\ 600 & 55 & 30 \\ 200 & 18 & 10\end{array}$

3.0

3-600 0.3-55 0.25-30

$600-2000 \quad 55-180 \quad 20-60$

miday

$$
\begin{aligned}
& 0.03 \\
& 1.5 \\
& 0.15 \\
& 2.1 \\
& 0.91
\end{aligned}
$$$$
0.03-2.1
$$

The porosity for the uppermost confined aquifers ranges between 0.3 fers ranges between 0.3
and 0.4 (30 to 408). The vertical hydraulic conaucivity in the interbeds ranges between $5 \times 10^{-}$

\subsection{8}

0.09

9. 1

m/aay and $20 \times 10^{-4} \mathrm{~m} / \mathrm{day}$. The storage coefficient approaches tho compressibility of water.

$0.08-9.1$

$5.0-20.0$ 
Hydraulie conduetivity

$\overline{1 \times 10^{-5}-3 \times 10^{-3}} \overline{3 \times 10^{-5}-9 \times 10^{-4}}$

$1 \times 10^{-3}-1 \times 10^{-2} \quad 3 \times 10^{-4}-3 \times 10^{-3}$

Transmisstivity

LE 7 day $\frac{m^{2} / \text { day }}{2 x 10-4 / 3 x 10}$

$\times 10^{-4}-3 \times 10^{-1} \quad 9 \times 10^{-5}-3 \times 10^{-2}$

veolcular basalt

Fractured, weathered
or brecciated basalt

Interbed

$3 \times 10^{-3}-5$

$3 \times 10^{-3}-10$

$3 \times 10^{-4}-1-5$

$9 \times 10^{-4}-3$

$9 \times 10^{-4}-9 \times 10^{-2}$

$9 \times 20-5-46$

$3 \times 10^{-3}-9$
Effective

Coeforaqe

Dimension 1eas

$0.1-1$

$2 \times 10^{-5}-1 \times 10^{-5}$

$\times 2 \times 10^{-4}$

$<1 \times 10^{-3}$

$<1 \times 10^{-2}$

avolume percent.

Table 2-37 Range of Hydrologic propertieg of lower Yakima Basalt flows and interbeds. Source: NWTSP (1976) 
tests (Table 2-38). The difference in these me.isurements is explained by La Sala and Doty (1971):
"These differences in values of hydraulic conductivity result, because these two types of tests measure different characteristics of the rocks. The field values of hydraulic conductivity were determined on a large volume of in-pice rocks. The basalt, as can be seen in outcrops, is cut by shrinkage cracks and other fractures which are capable of transmitting water. The field hydraulic conductivities, therefore, apply not only to the ability of the basalt flows to transmit water through intergranular pore spaces, but also through fractures. The laboratory tests were made on sma11 cylinders of rock that were selected to be free of open fractures and, therefore, indicate the hydraulic conductivity dependent on movement through intergranular pore spaces. The results of the tests indicate that the hydraulic conductivity of basalt flows results mainly from fractures."

Although the bulk of the permeability data currently available on basalts of the Pasco Basin is derived from well ARH-DC-1, some additional date is available. Tests conducted at hanford on well RSH-1 in 1976 yielded hydraulic conductivity values ranging from $1.5 \times 10^{-2}$ to $2.5 \times 10^{-5} \mathrm{~m} / \mathrm{day}$ (Raymond and Tillson, 1968). In tests Iun in 1978 on well DC-6 at Hanford, hydraulic conductivities ranging from 0.3 to $9.5 \times 10^{-5} \mathrm{~m} /$ day were observed (Apps et al, 1979).

\section{Vertical Pexmeability}

Little work has currently been done regarding a determination of the vertical component of perweability in the Columbia basalts. Vertical permeability is difficult to evaluate in situ since deep wells utilized for testing run parallel to vertical joint 


\begin{tabular}{|c|c|c|c|c|c|}
\hline $\begin{array}{c}\text { Core } \\
\text { number }\end{array}$ & \multicolumn{2}{|c|}{$\begin{array}{c}\text { Depth } \\
\text { (Meters) }\end{array}$} & \multicolumn{2}{|l|}{$\begin{array}{l}\text { Hydraulic } \\
\text { conduct Ivity }\end{array}$} & $\begin{array}{l}\text { Porostey } \\
\text { (percent) }\end{array}$ \\
\hline 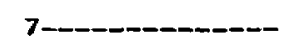 & 847.0 & 847.3 & $1.18 \times 10^{-5}$ & m/day & 10.5 \\
\hline 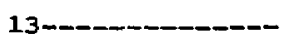 & 953.1 & 953.4 & $5.79 \times 10^{-6}$ & $\mathrm{~m} / \mathrm{day}$ & 2.1 \\
\hline 28-n-_- & 1306.0 & 1306.2 & $1.12 \times 10^{-5}$ & m/day & 10.9 \\
\hline
\end{tabular}


systems. Ledgerwood and Deju (1976), utilizing data developed by La Sala et al (1.973), suggest the vertical components of permeability to be approximately an order of magnitude lower than horizontal permeability. Tanaka et al (1974), in a modeling study of an area north of Hanford, attempted to match hydraulic conductivity to head response in an effort to develop a suitable valve for vertical conductivity. Tanaka concluded the vertical component of $\mathrm{K}$ should be between $3 \times 10^{-7}$ and $1 \times 10^{-5} \mathrm{~m} /$ day. Deju et al (1977), conclude hydraulic conductivities in the central volume of a dense, thick basalt are usually 2 or 3 orders of magnitude less than $10^{-9} \mathrm{~m} /$ day. An understanding of permeability anisotropits is critical to effective modeling of a deep repository. Further work on directional components of permeability needs to be cotpleted.

\section{Vertical Hydraulic Gradients}

In 1972, 5 piezometers were installed in well ARH-DC-1 as depicted in Figure 2-49. These piezometers have been monitored on a more or less continuous basis since. Data from these piezometers indicate there is a potential interconnection of basalt beds above the $888 \mathrm{~m}$ level. This is confirmed by the uniformity of the piezometric surfaces measured in the injection tests sumarized on Figure 2-48. Data collected from 1972 to 1976 also indicate an interconnection of beds in the 970 to $1480 \mathrm{~m}$. interval. Separating these two apparent flow regimes is the Umtanum flow unit. 


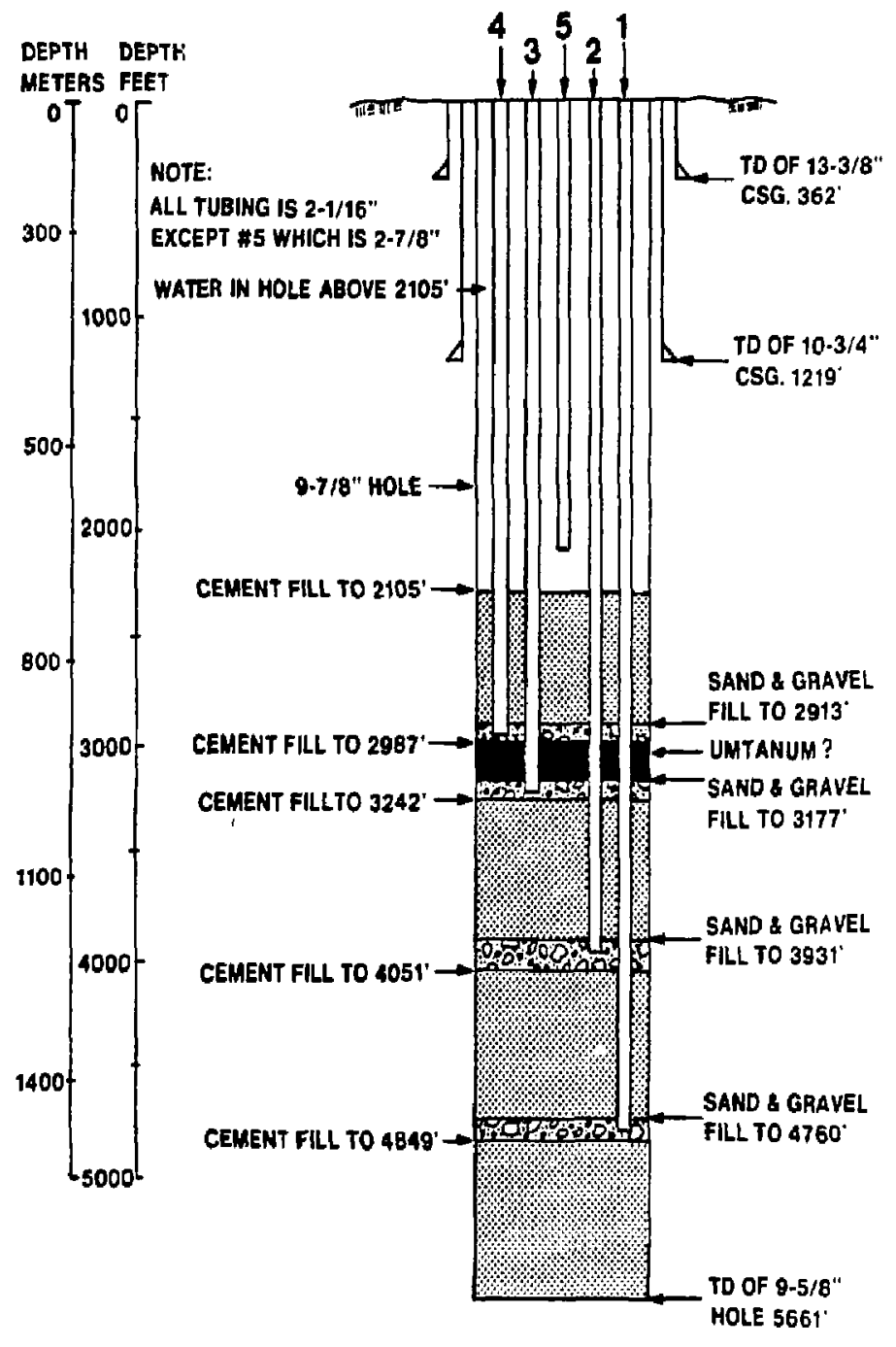

Figure 2-49 Piezometers installed in ARH-DC-1. Source: NWTSP (1976) 
During 1978, additional wells in the DC sequence were constructed as depicted in Figure 2-50. Although work with this series of wells continues and full data are not yet published, Apps et al (1979) suggest there are errors in piezometer readings from well DC-I created by leakage through cement seals between piezometers 1, 2, and 3. Readings from well DC-1 indicated that units below the Umtanum flow were hydraulically connected and that there was an upward gradient across this flow unit. Piezometric readings made in well DC-2, 40 feet from DC-1, confirm the hydraulic connection of beds above the Untanum, but show a sharp downward gradient immediately below this flow followed by a sharp upward gradient encountered at a point approximately $1000 \mathrm{ft}$. below the Umtenum. As illustrated in Figure 2-51, this pattern of gradient reversals was also confirmed in well DC-6, While some dense basalts within the Columbia River group are sufficiently impermeable to allow different heads to be maintained on various portions of the aquifer, this does not signify there exists an absolute hydraulic discontinuity between these aquifers. The head differential between beds continues to drive waters across the "confining layer" at a rate porportioned to the hydraulic conductivity of the strata and at a velocity inversely porportional to its effective porosity. 


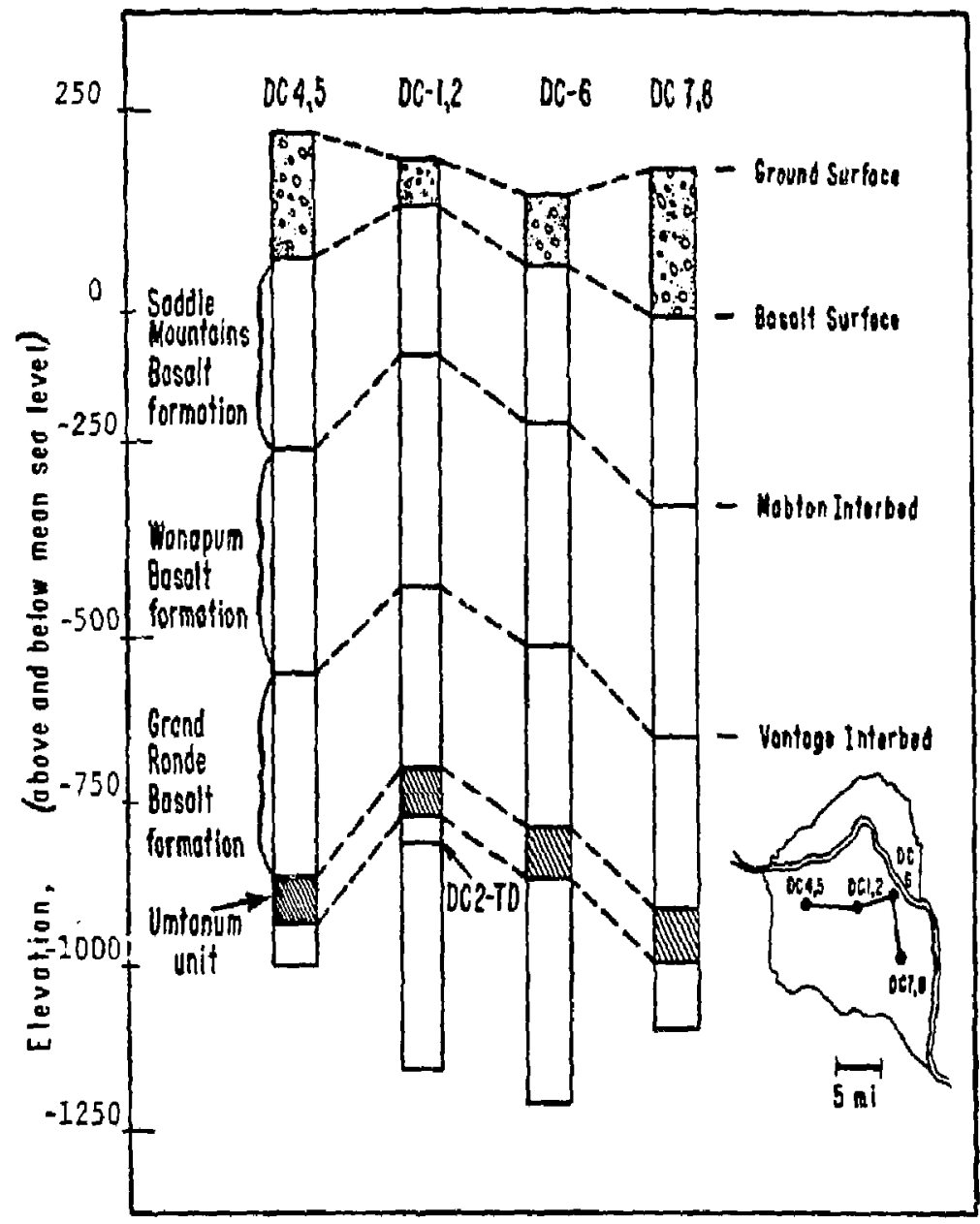

(Meters)

Figure 2-5D Generalized ba'alt atratigraphy within the Pasco Bacin. Source: Apps et al (1979) 


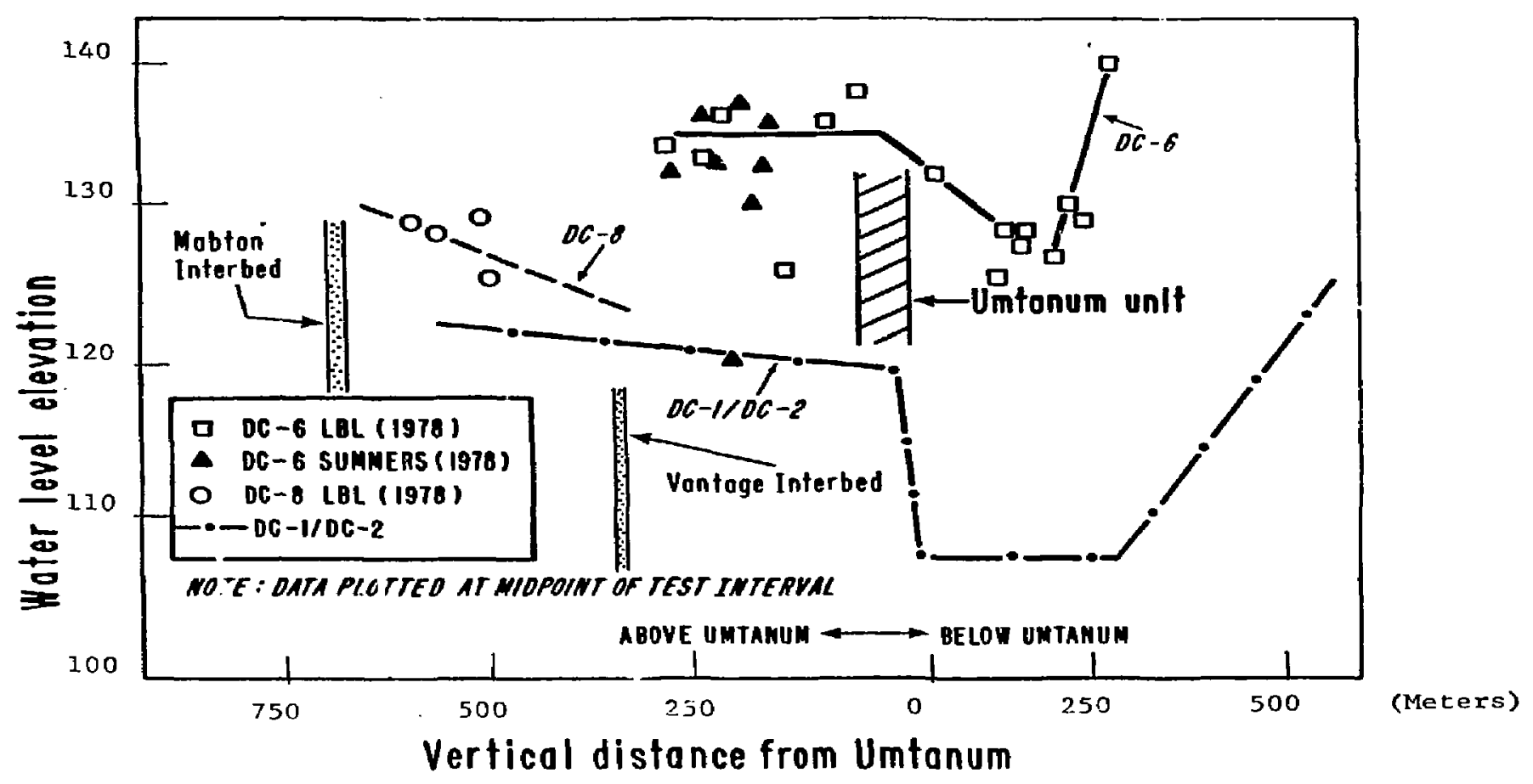

Figure 2-51 Summary of pressure data vs. stratigraphy. Source: Apps et a1 (1979) 


\section{Storage Coefficients}

Available data on storage coefficients of basalts are minimal. Utilizing well ARH-DC-1, estimates of storage coefficient for the confined basaltic flows were developed. These estimates are summarized on Table 2-39. A range of values of $S$ was observed from $1.8 \times 10^{-3}$ to $1.4 \times 10^{-6}$. However, these results were drawn from analysis of single well tests and are, at best, only order of magnitude estimates.

La Sala and Doty (1971) observe, "the storage coefficients of basaltic rocks should generally be smaller (than those observed in well ARH-DC-I) and, for the most dense, most competent rocks, should approach the value for the comoressibility of vater."

\section{Average Velocity of Ground Water}

Average velocities for ground water in various zones of basalt are suggested by La Sala and Doty (1971) on Table 2-41. They conclude that average velcsity ranges from $5 \times 10^{-2} \frac{\mathrm{dh}}{\mathrm{d} 1}$ to $5.0 \frac{\mathrm{dh}}{\mathrm{dI}} \mathrm{m} / \mathrm{day}$, where $\frac{d h}{d I}$ is gradient. Assuming a mean gradient in the confined aquifer at Hanford of .0006 meters per meter (CRWM, 1978), average velocities of ground water would range from $3 \times 10^{-5}$ to $3 \times 10^{-3} \mathrm{~m} / \mathrm{day}$.

The estimates of La Sala and Doty are based upon very minimal porosity data and limited information on hydraulic conductivity. Current programs should help better define average ground water velocities. 
TABLE 2-39 STORAGE COEFFICIENTS COMPUTED FROM HYDRAULIC TEST DATA, WELI ARH-DC-1

\begin{tabular}{lc}
$\begin{array}{c}\text { Depth Interval } \\
\text { (Meters) }\end{array}$ & $\begin{array}{c}\text { Storage Coefficient, } \\
\mathrm{S}\end{array}$ \\
\hline $110.3-126.8$ & 0.000066 \\
$405.4-463.3$ & $\underline{1 /} .0018$ \\
$536.4-594.4$ & .00063 \\
$958.9-986.3$ & .0000014
\end{tabular}

1/ This comparatively high-storage coefficient may reflect largely the characteristics of two sections of sand interlayered with the basaltic rocks in this zone.

Source: La Sale and Doty (1971) 


\section{Regional Ground Water Systems}

Detailed peizometric surface maps indicating direction of groundwater flow have been developed for the unconfined and the shallow confined aquifer in the Pasco basin (Committee on Waste Management, 1978). However, little is known of the direction of migration through deep basalts and interbeds. La Sala and Doty (1971) discuss the effects of ground-water flow through the deep basalts and interbeds and their potential recharge and discharge areas. Their investigations, however, are based upon meager data and the results remain unsubstantiated (NWTSP, 1976). 


\subsection{HYDROLOGY OF THE SYARE RIVER PLAIN}

\section{Origin}

The Snake River Plain is a structural basin covering an area of about $31,000 \mathrm{~km}^{2}$ in southern Idaho. As depicted on Figure 2-52, the basin is approximately $320 \mathrm{~km}$ in length and 50-70 km. in width. Geologic data on the basin are limited due to the lack of economic mineralization in the basalt sequence. However, since the siting of the Idaho National Engineering Laboratory (INEL) on the Snake River Plain in the early 1950's, sufficient work has been sponsored by the Department of Energy and the U.S. Ceological Survey to develop a quantitive knowledge of the basin as a whole and a more specific knowledge of the INEL site in particular.

It is thought that a north-south trending geosyncline lay across southem Idaho in late Precambrian time. Deposition of sandstenes and shales occurred in this broad depression through the early ordovician (Crittenden et al, 1971). As the Cordilleran geosyncline developed, deposition shifted to principally carbonate rocks during the later Paleozoic.

Beginning in the Permian anc continuing on into the Mesozoic, tectonic activity increased in the region. The Idaho Batholith 


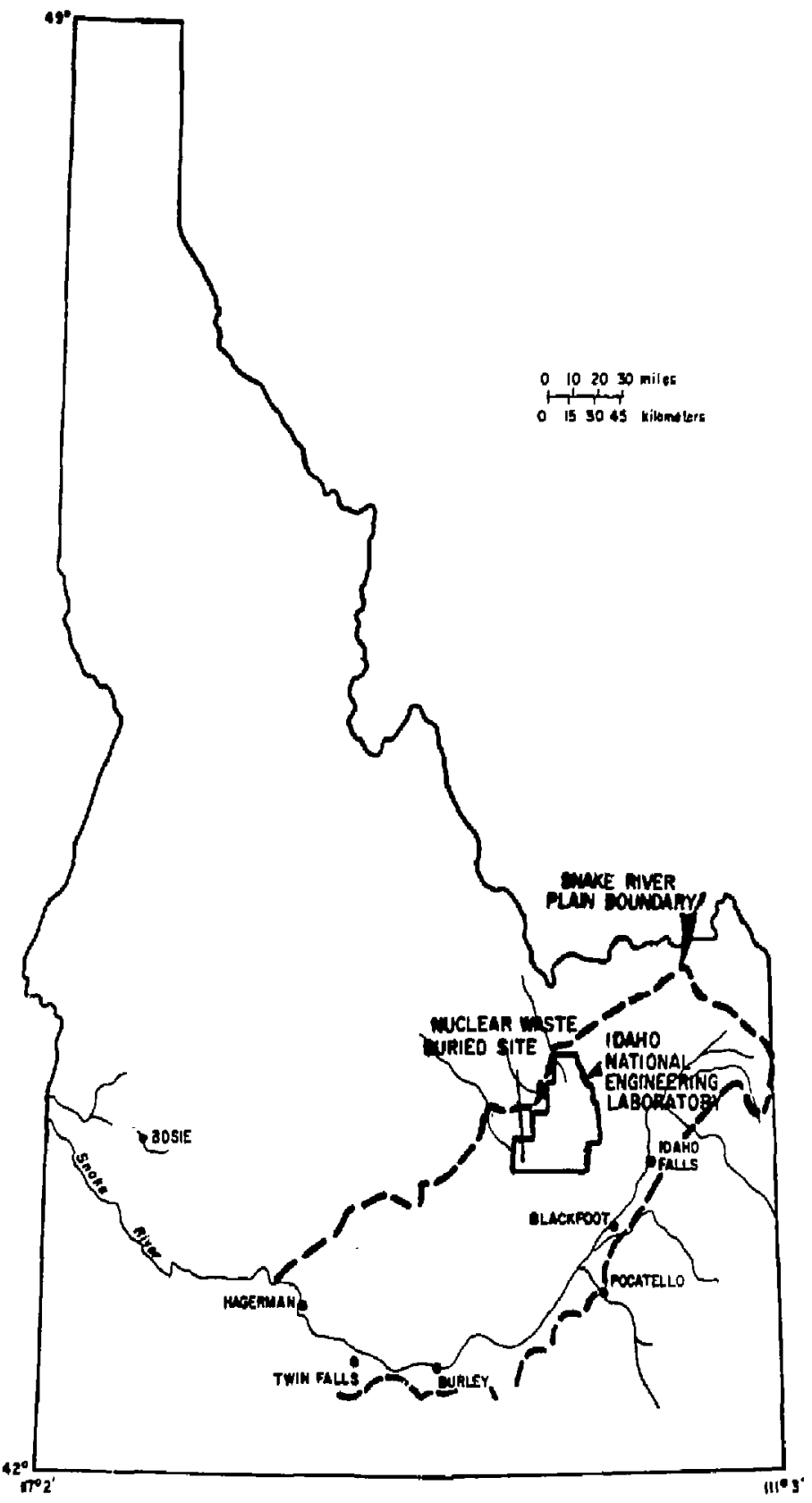

FIGURE 2-52 Location tap of Snake aiver Plain

Source: Robertson et al (1974) 
was emplaced to the north and west, and the resulting uplift provided a source of detritus for Mesozoic sedimentation on its flanks. By the middle of the Mesozoic, approximately 15,250 m. of Paleozoic and 10,700 m. of Mesozoic rocks had filled the basin. Uplift and tectonism continued, culminating in the Laramide Orogeny during the late Cretaceous.

By early Cenozoic time, deposition had terminated and erosion of the uplifted sediments had begun. Basin and range faulting during the Miocene created a rugged mountain range in southern Idaho, bounded on the north and west by the Idaho batholith and on the east by large basin and range horsts and grabens. This topography was maintained until the early Pliocene when tectonic events began to create the basin which developed into the Snake River Plaith.

A number of theories have been presented for the development of the basin in which the basalts of the Snake River Plain were deposited (Lindgren (1898), Russel (1902), Kirkham (1931), Hamilton (1963)), Current1y, the most accepted theory includes the development of a large downfaulted graben inundated by flood basalts. The development of this graben is sumarized by Robertson et al, (1974):

"Th1s hypothesis proposes that in Iate Miocene the granitic terrain of the Idaho batholith extended southward to the south edge of the present plain where it 
either thinned considerably or was displaced westward. Tension during the early Pliocene, probably due to subcrustal forces similar to those envisaged by Hamilton and Myers (1966), produced the present Snake River graben into which the southern tip of the batholith subsided.

Along with subcrustal tension directly reponsible for the grabening, magma developed in the subcrust, perhaps fractionated from a tholeitte into immiscible rhyolite and olivine basalt (Hamilton, 1965), and erupted along tensional openings in the overlying rocks. Sialic volcanism occurred first and covered the floor of the graben as well as much of the surrounding region with tuff and flows (Idavada Volcanics). Effusive removal of subcrustal material from beneath the graben allowed downfaulting to continue and the Snake River Plain crustal block settled into the mantle. By middle Pliocene time all the rhyolite was gone from the magma chamber and eruption of olivine basalt began. Basalt flows were restricted to filling the graben though some flowed short cistances up valleys in the adjoining blocks (Crosthwaite and others, 1970). It is the addition of this subcrustal material to the top of the Snake River graben that accounts for the maintenance of isostasy. Figure 2-53 depicts these stages in the hypothetical grabening of the Snake River Plain."

\section{Stratigraphy}

The sequence of volcanic rock which fills the graben is thought to range from 300 to over $3000 \mathrm{~m}$. in thickness (Robertson, 1974). Early wells constructed at INEL showed the upper 450 meters of the section to consist of a series of thin basalt flows 3 to $25 \mathrm{~m}$. in thickness, interbedded with fluvial, lacustrine, eolian and pyroclastic sediments. A cross section of the nuclear waste burial ground at INEL, Figure 2-54, 1dentifies the interbedded sediments in the upper portion of the sequence. 


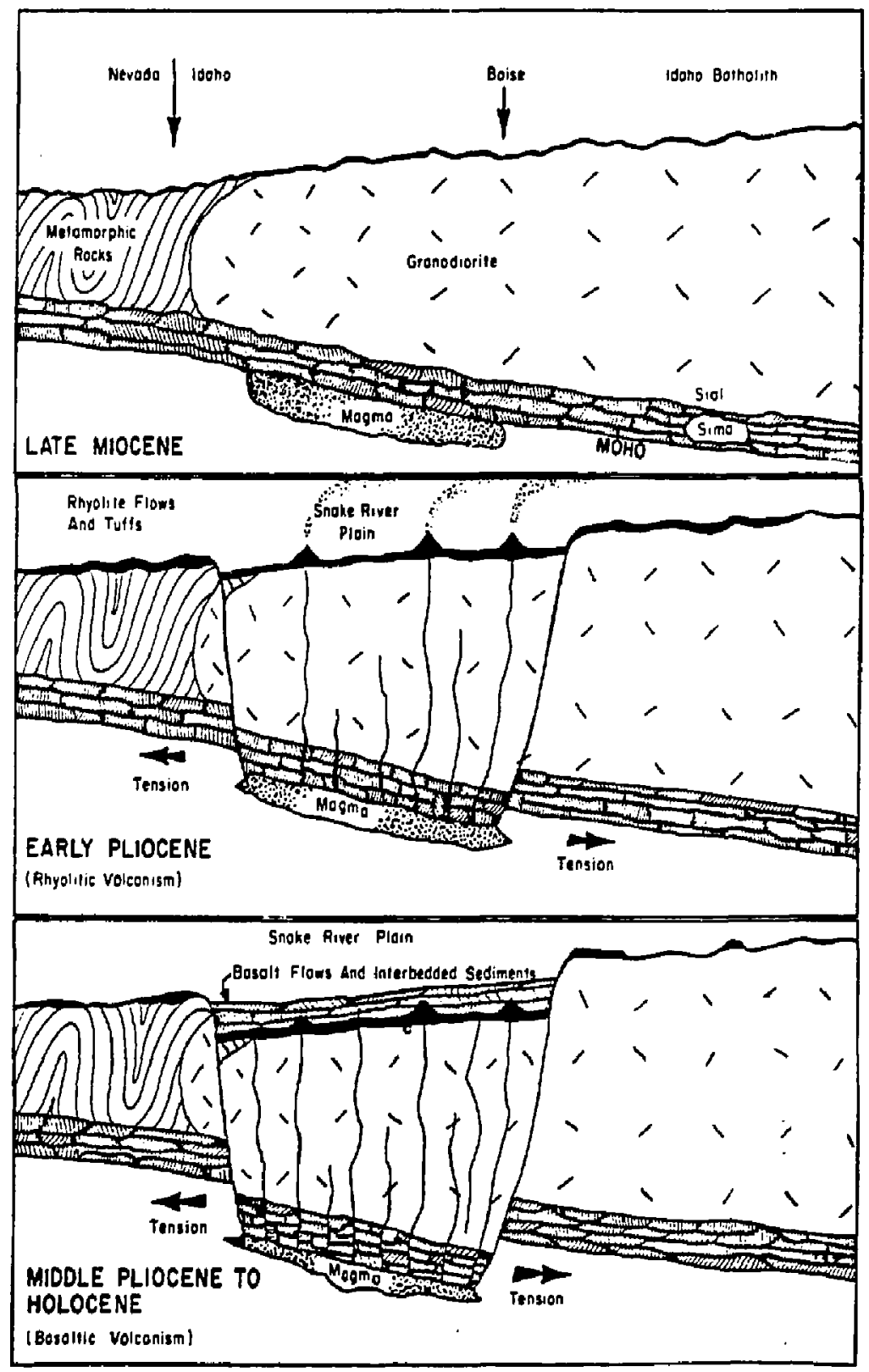

FIGURE 2-53 Crose sections showing hypothetical stages of grabening during formation of the Snake River Plain

Source: Robertion et al (1974) 


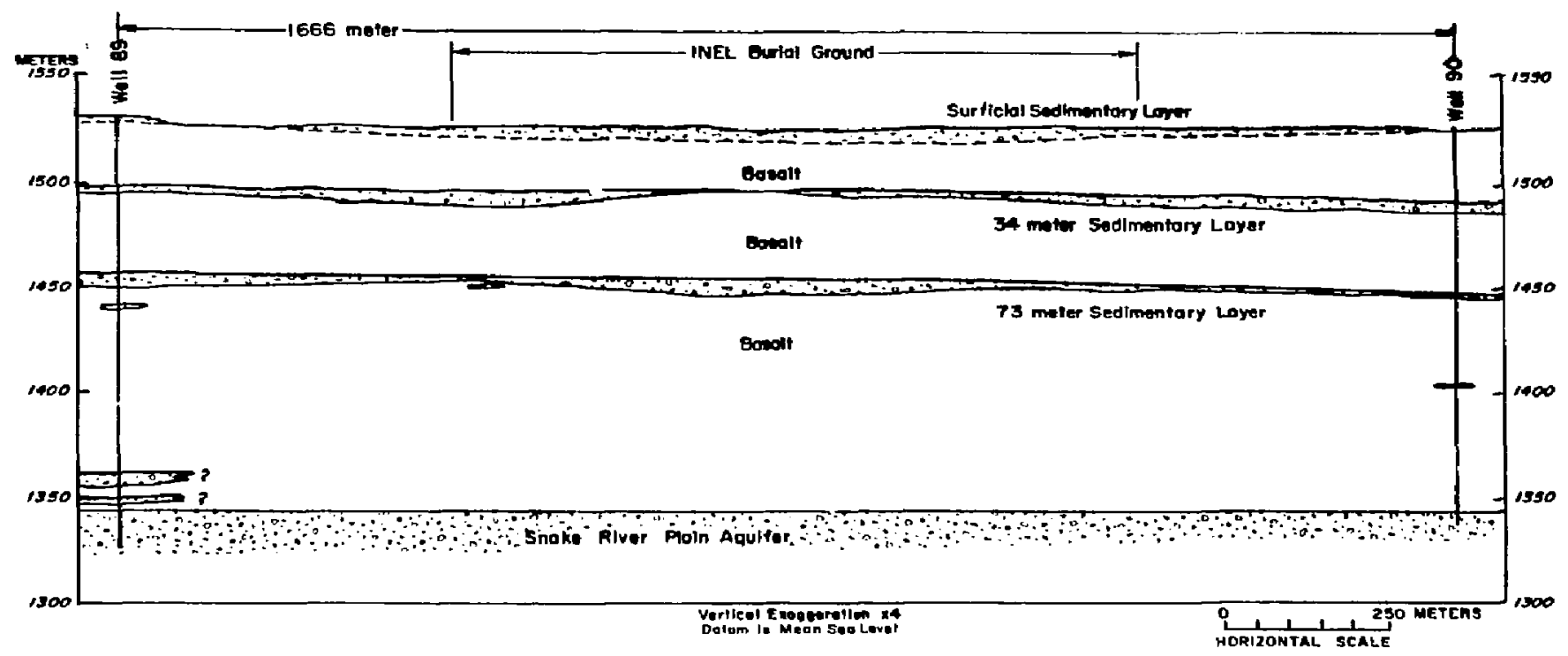


In May 1979, the Department of Energy completsd a 3159 ஐ. geothermal test well at the Idaho National Engineering Laboratories approximately $30 \mathrm{~km}$. north of the burial site. The upper $745 \mathrm{~m}$. of this well penetrated basalt flows and sedimentary interbeds. Below 745 m. a sequence was encountered which consists of rhyolitic welded ash-flow tuffs, air fall ash deposits, nonwelded ash-flow tuffs and volcaniclastic sediments. Doherty et a1, (1979) suggests these rocks are part of an intracaldera fill and that a collapsed caldera approximately $25 \mathrm{~km}$. In diameter may exist in the region of WeIl INEL: 1 .

\section{Characteristics of Ground Water Flow}

Ground water flow in the Snake River Plain aquifer occurs principally along the upper and lower contacts of successive basaltic flows which have large and irregular fractures, fissures and other voids (Robertson, 1974). Barraclough et al, (1976) observed the tops of many flows core-drilled at INEL to be highly vesicular with numerous intersecting fractures resulting in high porosity and permeability. The center of the flows was observed to be relatively dense and of a significantly lower porosity and permeability. The lowermost portion of the flow was resicular and fractured, though to a lesser degree than the flow top. Consistent with basalts in other regions, columner jointing is apparent in the flows of the Snake River Plain. 
Ground water flow paths are not well defined in the rhyolitic ash flow sequence below $745 \mathrm{~m}$. Doherty et al (1979) notes that most of the rhyolitic rocks are devitrified and dense. Nearly all fractures in recovered core are sealed by propylitic alteration products including calcite, quartz, hematite, pyrite, a septechlorite mineral, and a variety of clays. Although most of the fractures, joints and vesicles in the rhyolite rocks have been filled by products of hydrothermal alteration, there may be large scale fracture features condusive to the flow of ground water a: these depths. Doherty et al (1979) in their study of gecthermal potential state, "Porous and fracturer rocks in ring fracture zones (around the collapsed caldera) provide channel ways for circulation and storage of water and, therefore, rocks in these zones may be likely targets for further geothermal explorations."

\section{Hydraulic Conductivity}

Little reliable hydraulic conductivity data exist for the Snake River Plain aquifer. Such data as is available is derived from water well tests and tests at INEL on wells generally less than $500 \mathrm{~m}$. In depth. Available data suggests the greatest permeabilities may be found in the upper $200 \mathrm{~m}$. of the aquifer and permeabilities may significantly decline from this point downward (Robertson,1974). However, insufficient deep well data are available to fully confirm this conclusion. 
Pumping tests conducted by Norvitch et al (1969), on irrigation wells penetrating the basalt aquifer showed transmissivities to range from $1.25 \times 10^{4}$ to $1.25 \times 10^{5} \mathrm{~m}^{2} / \mathrm{d}$, and to average $6 \times 10^{4} \mathrm{~m}^{2} / \mathrm{d}$. In similar tests at INEL, transmissivities were observed to range from $3.7 \times 10^{2}$ to $2.2 \times 10^{5} \mathrm{~m}^{2} / \mathrm{d}$, and to average 2.5 $\times 10^{4} \mathrm{u}^{2} / \mathrm{d}$. (Robertson, 1974). Barraclough (1976), in well tests at INEL, found hydraulic conductivity to vary quite substantially within very short distances. He observed values of hydraulic condustivicy to range from 30 to 3000 $m /$ day. Barraclough further observed that vertical components of permeability are significantly less than horizontal components. In tests of a $30 \mathrm{~m}$. thick section of basalt, King (1968) found horizontal conductivities to average 17 $\mathrm{m} /$ day while vertical components averaged $4.5 \mathrm{~m} /$ day. At this test site and depth, the horizontal component of hydraulic conductivity was found to be 3.7 times that of the vertical component; however, the data is insufficient to make generalizations about the rock mass as a whole.

The sedimeritary interbeds rithin the Snake River Plain aquifer are generally more homogeneous in hydraulic pro ties and have a greater porosity, greater capillary pressure and lower permeability than the basalt. (Barraclough, 1976). Unlike the Columbia River region, sedimentary interbeds in the Snake River Plain aquifer are generally barriers to the 
downward movement of ground water (Doe, written communication, 1979). Vertical hydra.11ic conductivities measured from core of the $34 \mathrm{~m}$. and $73-\mathrm{m}$. interbeds at the INEL burial ground are sumbarized on Table 2-40. The vertical conductivities of these strata were fo. nd to range from $1.67 \times 10^{-7}=$ to $3.0 \mathrm{~m} / \mathrm{d}$. These values are a factor of about 20 less than the above described permeabilities for in-place basalt.

The basalt-sediment interface is suspected of having vertical permeabilities even lower than that of the interbeds. Barraclough (19\%) suggests:

\begin{abstract}
"An additional and even greater constraint occurs at the base of each sedimentary layer, at the sedimentbasalt interface. This is culused by the discontinuity of pore spaces from the sediment to the basalt due both to the lower porosity of the basalt and to the relatively great distanc-s between its fractures. In other words, at the interface, perhaps only $10 \%$ of the basalt surface is composed of permeable openings, and these are partially filled by sediment. The other $90 \%$ is virtualiy impermeable. This, in effect, provides a thin skin that is estimated to have one-tenth or less of the permeability of the sediments alone."
\end{abstract}

In many areas of the Snake River Plain, the vertical permeabilities of sediments lying above the zone of water saturation are sufficiently low as to allow perched water tables to exist locally. Perched waters have been identified on the burial ground site at INEL. However, leakage of the TRA disposal ponds at INEL and the subsequent contamination of the Snake River Plain aquifer indicates that oome vertical leakage does occur through the sediments. 
Table 2-45 Vertical Hydraulic Conductivities of

Sedimentary Interbeds - INDL Wells 87-96

\begin{tabular}{|c|c|c|}
\hline Well No. & Depth Zone & $\begin{array}{c}\text { Vertical } \\
\text { Hydraulic Conductivity } \\
\mathrm{M} / \text { day }\end{array}$ \\
\hline 87 & C & $2.5 \times 10_{-1}^{-2}$ \\
\hline 87 & C & $3.2 \times 10^{-1}$ \\
\hline 88 & C & $1.3 \times 10_{-5}$ \\
\hline 88 & $c$ & $3.5 \times 10^{-7}$ \\
\hline 88 & C & $8 \times 10_{-6}$ \\
\hline 88 & C & $3.1 \times 10^{-7}$ \\
\hline 89 & C & $1.6 \times 10_{-5}$ \\
\hline 89 & $C$ & $6.1 \times 10^{-6}$ \\
\hline 89 & $\mathrm{C}$ & $5.9 \times 10^{2}$ \\
\hline 90 & C & $2.9 \times 10_{-?}$ \\
\hline 91 & A & $1.3 \times 10$ \\
\hline 91 & B & \\
\hline 91 & C & $7.1 \times 10_{-1}^{1}$ \\
\hline 91 & C & $2.6 \times 10_{-4}$ \\
\hline 92 & A & $5.5 \times 10^{-4}$ \\
\hline 92 & C & $\begin{array}{ll}2.7 & -2\end{array}$ \\
\hline 92 & C & $2.7 \times 10_{-6}^{-2}$ \\
\hline 92 & C & $2.1 \times 10^{-4}$ \\
\hline 93 & A & $2.6 \times 10_{-2}$ \\
\hline 93 & C & $5.5 \times 10^{-4}$ \\
\hline 94 & A & $2.7 \times 10^{-6}$ \\
\hline 94 & A & $9.6 \times 10^{-1}$ \\
\hline 94 & B & $7.6 \times 10$ \\
\hline
\end{tabular}


Table 2-40 (Cont'd)

\begin{tabular}{lll}
\hline We11 No. & Depth Zone & $\begin{array}{c}\text { Vertical } \\
\text { Hydralic Conductivity } \\
\text { M/day) }\end{array}$ \\
94 & C & $1.6 \times 10^{-2}$ \\
94 & C & $2.3 \times 10^{-1}$ \\
94 & C & $7.3 \times 10^{-5}$ \\
94 & C & $5.5 \times 10^{-5}$ \\
95 & A & $7.9 \times 10^{-3}$ \\
95 & A & $5.3 \times 10^{-1}$ \\
95 & B & $1.5 \times 10^{-1}$ \\
95 & B & $3.1 \times 10^{-6}$ \\
95 & C & $2.8 \times 10^{-1}$ \\
95 & C & $9.3 \times 10^{-1}$ \\
96 & A & $5.9 \times 10^{-1}$ \\
96 & B & $6.7 \times 10^{-6}$ \\
96 & C & $1.9 \times 10^{-3}$
\end{tabular}

\begin{tabular}{cc} 
Depth Zone & \multicolumn{1}{c}{ Depth } \\
$A$ & 0.8 meters \\
$B$ & $23-38$ \\
$C$ & $69-84$
\end{tabular}

Source: Barraclough (1976) 


\section{Storage Coefficients}

Estimates of storage coefficient for the Snake River Plain aquifer are minimal in the literature. Norvitch et al (1969) determined the average storage coefficient for that portion of the aquifer pentrated by water wells on the plain to range from .001 to 0.2 . In later work at INEL, pumping test data on wells less than $500 \mathrm{~m}$. ir depth showed the storage coefficient of the penetrated section to range from .01 to .06 .

\section{Average Velocity of Ground Water}

With the minimal date available, average flow rates are wifficult to assess. Tracer tests at INEL identified zones with flow rates of 1 to $7 \mathrm{~m} / \mathrm{d}$, however, these rates are not necessarily representative of velocities throughout the aquifer. Barraclough et al (1967) suggest the average effectiv? porosity of the upper 610 meters of the aquifer is 5 to $10 \%$. Utilizing Barraclough's conclusions and gradients estimated by Mundorff et al (1964), Robertson et al (1974) estimated the average flow through a one kilometer section of the aquifer on the southern edge of INEI, to be $2 \mathrm{~m}^{3} / \mathrm{s}$. This is equivalent to a flow of $.18 \mathrm{~m}^{3}$ per $\mathrm{m}^{2}$ normal to the direction of flow, or utilizing an $8 \%$ effective porosity, an average flow velocity of $2.4 \mathrm{~m} / \mathrm{d}$.

\section{Regional Ground Water System}

Data from irrigation wells across the Snake River Plain indicate that water in the upper $500 \mathrm{~m}$, of the aquifer migrates in a generally southwesterly direction as suggested by Mundorff $:=$ al (1964), 
Figure 2-55. Little, if any, work has been done to delineate the rate and direction of movement of deeper waters. Although regionally deeper waters probably also migrate southwesterly, locally the directions of ground water flow may vary substantially.

At INEL, Barraclough, Robertson, and others have studied in detailed the ground water flow patterns at the burial site and disposal ponds. These studies, sumarized in Barroclough et al (1976), describe flow in the upper 3 basalt series and the sedimentary interbeds. It was found in this investigation that while regional water movement through the area was to the southwest, movement locally at the burial ground was northeasterly. This was attributed to recharge from the Big Lost River and its flood diversion areas to the west. 


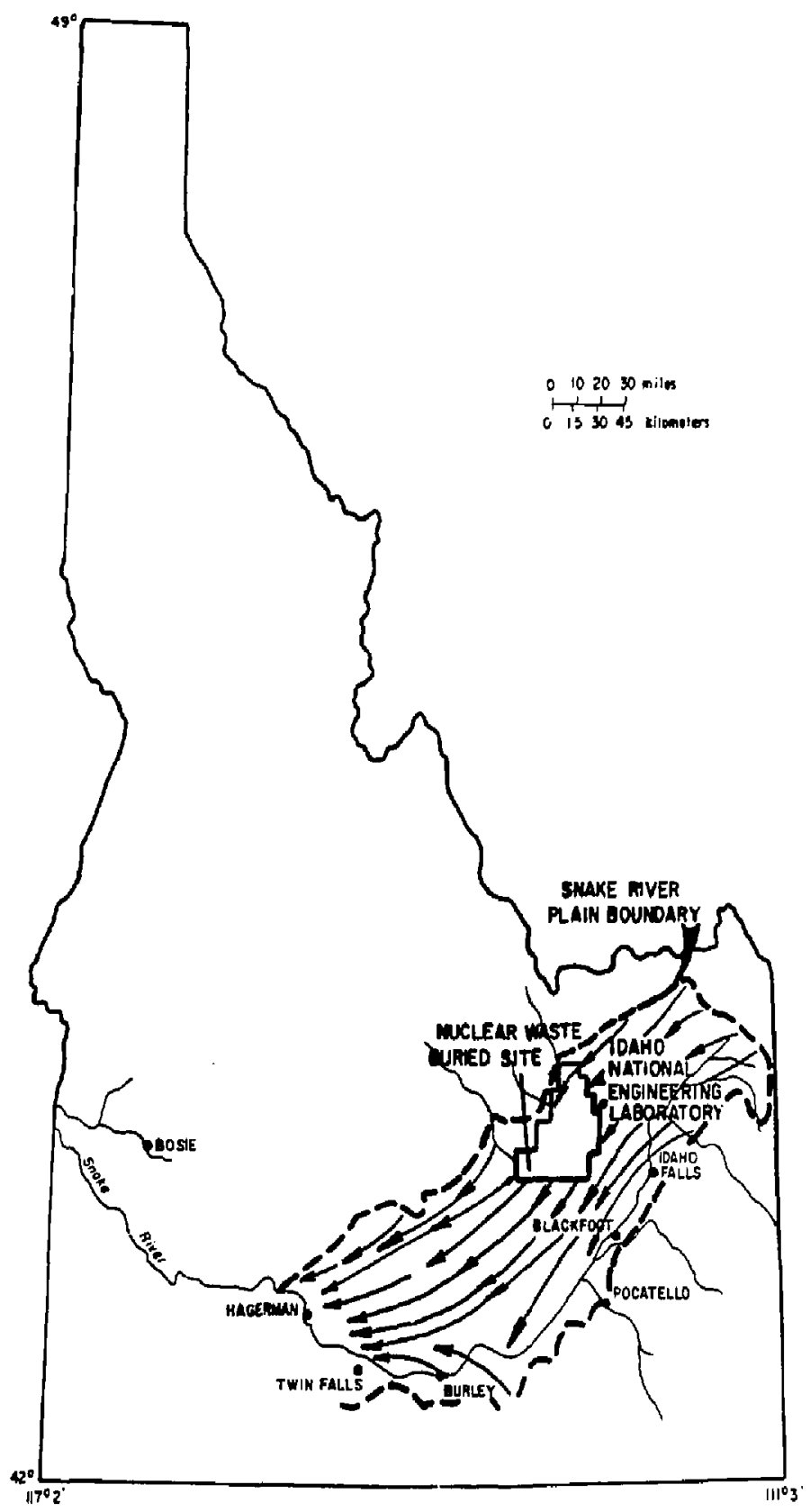

FIGURE 2-55 Reglonal ground water flow -

Snake River Plain

Sourca: Robertion et al (1974) 


\subsection{HYDROLOGY OF THE MODOC PLATEAU}

\section{Origin}

The Modoc plateau lies south of the Columbia River and Snake River Plain basalts, north of the Sierras and west of the Cascades and Coastal ranges. The region consists predominately of a series of north to northwest trending block-faulted mountain ranges. Tectonism culminated in the Miocene or Pliocene on the plateau; however, faulting has continued into Recent time. Intervening basins between block-fault ranges have been filled with a series of basalt flows ranging from Miocene to Recent in age. These basalts are often interbedded with lacustrine and fluvial mudstones, siltstones and sandstones, and volcaniclastic materials. Because tectonism has been continuous, many of the older flows are now faulted and tilted.

\section{Hydrology of Basalt Flows}

The intact basalt has a low porosity and permeability. Most ground-water flow occurs in ureccia layers between flow units, clinker zones, vesicular zones, joints or lava tunnels (Mack, 1960; Hood, 1960; Brown and Newcomb, 1961; Foxworthy, 1961; Newcomb, 1961). Faults in the basalt flows usually form vertical conduits that enhance permeability rather than form barriers to horizontal flow. Interbeds are discontinuous and generally are only of local significance. 
Specific hydrologic data on the aquifer is sparse. Although sustained well yields of 50 to 200 gpm are common, well production is highly variable. Brown and Newcomb (1962) observed transmissivities to range from 1050 to $3720 \mathrm{~m}^{2} /$ day and storage coefficients to range from $1.4 \times 10^{-3}$ to $2.4 \times 10^{-3}$.

Regionally, ground water occurrences in the Modoc Plateau are restricted to many structural basins or grabens between block-fault sequences. These basins are surrounded by crystalline rock of low permeability which provide very little recharge. Most recharge occurs through precipitation or seepage from irrigation facilities or streams. 


\subsection{REFERE:i_ES}

Abegglen, Donn E., Alfred T. Wallace and Roy E. H1li12ms, 1970 , The Effects of Drain Wells on the Ground-water Rualty of the Snake River Pla1n; Idaho Bureau of Mines and Geolog: Pamphlet 148 .

Atlant1c Rlchfleld Hanford Co., 1976, Pre' iminary Feasib1lity Study on Storage of Radioactive Wastes in Colurkta R:ver Basalts; ARH-ST-137.

Barraclough, J. T., 1979, Geohydrology of the Eastern Snake River Plain, Idaho, as Shown by a Two-M1le-Deep Weli, U.S.G.S.

Barraclough, J. T. et al, 1976, Hydrology of the Sol1t Waste Burlal Ground, As Related to the Potential Migration of Radionuclides, Idaho, Nat1onal EngIneering Laboratory; U.S.G.S. Open-F1le Report 76-471.

Bear, J., 1972, Dynamies of Fluids in Porous Med1a, Amerian Elsevier, New York, op. 764.

Birch, F., and Clark, H., The Tharmal Conductivity of Rocks and Its Dependence upon Temperature and Composition, American Journal of Sclence, Yol. 238, Ho. 8, August 1940.

Brown, D.J. and R.K. Ledgerwood, 1973, "Stratigra phy and Structure of Yak1ma Basalt in Pasco Basin, Washington," Geologic Field Trips in Northern Oregon and Southern Weshington, Oregon Department of Geology and Mineral Industries, Bull. 77, 171-181.

Brown, S. G. and R. C. Newcomb, 1962, Ground-water Rescurces of Cow Valley Malheur County, Oregon; U.S.G.S. Water Sugply Paper 1619-M, $38 \mathrm{p}$.

Bureau of Reclamat1on, 1977, Ground Water Manual; A Water Rasources Techn1cal Publication, U.S. Dept. of Inter1or.

Committee on Radioactive Waste Management (CRWM), Commission on Natural Resources, Nat1onal Research Council

Crittenden, M.D.,Jr., F.E. Schaeffer, D.E. Trimble, and I.A. Woodward, 1971, "Nomenclature and Correlation of Some Upper Precambrian and Basal Cambrian Sequences in Western Utah and Southeastern Idaho", Geol. Soc. Amer1ca Bull., Vol 82, pp. 581-602.

Crosthwa1te, C.A. Thomas, K.L. Dyer, 1970, water Resources in the BIg Lost RIver Basin, South-Central Idaho, U.S. Geol. survey Open-F1le Report. 
Dames and Moore, 1978, Technical Support for GEIS: Rad1oactive Waste Isolation in Geologic Formations, Y/OWI/TH/-36/21, Vo1. 21, Ground Water Movement and Nucilde Transport.

Davis, Stanley N. and Roger J. M. Delliest, 1966, Hydrogeology, N.Y., John Wiley \& Sons.

Deju, R. A. et al, 1977, Env1ronmental Factors Needed to Establish the Geotechnical Feas1b1lity of Storing Radioactive Waste in. Columbia River Basalt, RHO-ST-8.

Dewlest, R. J. M., 1970, Geohydrology, New York, J. Wliey \& Sons, p. 366 .

Doherty, Dav1d J., Lisa A. McBroome and Mel A. Kuntz, 1979, Preliminary Geological Interpretation and Lithologic Log of the Exploratory Geothermal Test Well (INEL-1), Idaho National Engineering Laboratory, Eastern Snake River Pla1n, Idaho, U.S.G.S. Open-F1ie Report 79-1248.

Eddy, Paul A., 1969, Geohydrology of the Columbia Basin Preject Area, Washington, abs, ir. Northwest Science, v 43, n 1 , p. 35 .

Fenix and Scisson, 1969, Exploratory Report, Exploratory Hole. ARH-DC-1. Richlend, Wash.: Atlantic Richfleld Hanford Company.

Foxworthy, B. L., 1961, Deformed Basalt1c Caprock as an Aquilfer at Cok Valley, Oregon; U.S.G.S. Prof. Faper 424-C, p. C-150 - C-151.

Foxtorthy, B. L. and C. T. Bryant, 19ó?, Art1fic1al Recharge Through a kell Tapping Basalt Aquifers at the Dalles, Oregon, U.S.G.S. Water Supply Paper 1594-E.

Geohydrological Studies for Nuclear waste Isolation at the Banford Reservation, Volume II: FInal Report

Hamliton, Warren, 1963, "Overlapping of Late Mesozoic Orogens in Western Idaho", Geol. Soc. America Bull., Vol 74, pp. $779-788$.

1965, Geology and Petrogenesis of the Island Park Caldera of Rhyolite and Basalt, Eastern Idaho, U.S. Geol. Survey Frof. Peper 504-C.

Esmilitón, Warren and W.B. Myers, 1966, "Cenozoic Tectonics of the Western United States". Rev. Geophysics, Vol. 4, pp. 509-549.

Holmes, A., 1965, Princ1ples of Physical Geology, 2nd Ed. Ronela Press. New York, $1288 \mathrm{p}$. 
Jones, P. H., 1961, Hydrology of Waste Disposal, Nationa? Reactor Testing Station, Idaho; U.S.G.S. Open-F1le Feport IDO-22042, Issued by U.S. Atomic Energy Comin., Idaho ralls, Ilabo, 82 p., 70 11gs.

K:Ig, L.G., 1C58, Mathematical Models for Underground Injection of Gaseous Westes into the Vadose Zone: Battelle Memorial Institute, BNWL-9L5.

Kirkham, V.R.D., 2931, Snake River Downwarp: Jour, Geology, Vol 39, pp. 456-482.

Konikow, L. F. and J. D. Bredehoeft, 1978, Computer Model of Two-Dimensional Solute Transport and D1spersion 1n Groind Water; Techniques of Water-Resources Inves:1-ation, Ini $7-\mathrm{C2}, 90 \mathrm{p}$.

Lange, N.A., 1956, Lange's Handbook of Chemistry, New York
McGraw-Hill.

LaSala, A. M. Jr., and G. C. Doty, 1970, Prellminary Evalua:ion of Hydrolog1c Factors Related to Radloactive Waste Storage In Basalt1c Rocks at Hanford; U.S.G.S. Admin. Report, 1n Nuclear Sclence Atstract, v 25, n 21, art 48606.

LaSala, A. M. Jr., G. C. Doty, and F. J. Pearson, Jr., 1972, A Preliminary Evaluation of Reglonal Ground-water Flow in South-Central Washington; U.S.G.S. WRD AdmIn. Report, 53 p.

Ledgerwosd, R.K. and R.A. Defu, 1976, Hydrology of the Uppermast Confined Aquifers Underlying the Hanford Reservati on, US-ERDA Report ARH-SA-253, Atiantic Pichpield Henford Compeny,

L'ndgren, Haldemar, 1898, "Gellagic At'as of the United States, Boise Fol'?, Idah?", U.S. Gerl. Survey.

Luz1er, J. E. and J. A. Skrivan, 1975, Dig1tal Simulation and Projection of Water-Level Declines in Basalt Aquifers of the Odessa-Lind Area, East-Central WashIngton; U.S.G.S. Water Supply Paper 2036.

MacDonald, G. A., 1966, Geolozy of the Cascade Range and Modoc Plateau; 1n Geology of Northern California, Bulletin 190, California Division of Mines and Geology, San Franc1sco, 508 p.

Hack, Seymour, 1960, Geology and Ground-water Features of Shasta valiey, St.sksyou County, California; U.S.G.S. Water Supply Faper 1484, 115 p. 
Meinzer, 0. E., 1923, The Occurrenze of Ground Water In the United States, W1th a Discussion of Princ1ples; U.S.G.S. Water Supply Paper 489, $321 \mathrm{p}$.

Mundorfs, M. J., E. G. Crosthwalte and Chabot K1lburn, 1964, Ground Water for Irrigation in the Snake RIver Basin in Idaho, U.S.G.S. Water Supply Paper 1654, 224 p.

Mvers. C.W. 197?, Yak'ma Basalt Flsws Near Vantage, and from Core Hoies in the Pasco Basin, Hash'ngton, PED. Dissertation, Iniversity of California at Santa Criz, Santa Crue, California, p.147.

Myers, C.W. and D.J. Brown, 1973, "Stratigraphy" of the Yakime Basalt in the Pascs Basin, Washington:" (abstract) Gesl. Soc. of Amer. (Cordilleran Section,) 5(1), 8C

National Waste Terminal Storage Program (NWTSP) of the U.S. Energy Research and Development Admlnistration by Atlentic Richfield Hanford Company under Contract $\mathrm{E}(45-1)-2130$.

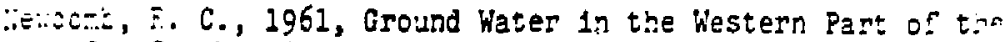
Con Creek and Soldier Creek Grazing UnIts, Malteir county, Orezon; U.S.G.S. Water Supply Paper 1475-E, pp. 158-172.

1969, Effects of Tectonic Structure on the Oacurrence of Ground Water in the Basalt of the Columila River Group of the Dalles Area, Oregon and Wastington; U.S.G.S. Prof. Paper 383-C, 105 p.

Norvitch, R.F., C.A. Thomes, and R.G. Mediton, 1969, Artificial Recherge to the Snake Plain Aquifer; an Evaluation of Potent1al and Effect: Water Information Bulletin No. 12, issued by Idaho Department of Reclamation, Bo1se, Idaho, 59 pagea.

4

P1per, A. M., 1975, Hypothet1cal Prototype S1tes of Repositories for Radioactlve Wastes: Flood Basalt; ORNI Subcontract 3745.

Ploen, h. M., T. W, Robinson, and C. F. Park, Jr., 1939, Geology and Ground-Water Resources of the Harney Basin, Oregon; U.S.G.S. Water Supply Paper 841, $189 \mathrm{p}$.

Raymond, J.R. and D.D. T11lson 1968, Evaluation of a Thick Basalt Sequence in South-Centrel Heshington. BNWL-776. Richland, Hash.: Battelle Paciflc Northwest Iaboratories

Roberison, J. B. and J. T. Barraclough, 1973, Radioact1ve and Chemical Waste Transport in Ground Water at Nat1onal Reactor Testing Station, Idaho; 20-year care history and digltal mode1 (abs); American Assoc1ation of Petroleum Geologists Bulietin, v $57, n$ B, pp. 1603-1604. 
Fobertson, J. B., Robert Schoen and J. T. Barraclough, 1974, The Infiuence of Ilould Waste Disposal on the Geoche=1stry ef Viater at the National Reactor Testing Station, Idaho 1952-2970; U.S.G.S. Report UC-70.

Fussell, I.C., 1902, Geology and Watgr Resources of the Bneke RIver Pla1n of Idaho, US Geol. Survey Bull. p. 199.

Sotelsesecr, A. E., 1961, General Theory of Dispersion 1n Porous Meiza, in Journal of Geophysical Research, v 66, n 10 .

Skititzke, H. E. and J. A. da Costa, 1962, The Ground-kater Flow System in the Snake Rtver Pialn, Idaho - Ar Idealized Ana1ys15; U.S.G.S. Water Supply Paper 1536-D, Pp. 47-67.

Stearns, H. T., L. Crandall and W. G. Stewerd, 1938, Geology and Groundwater Resources of the Snake RIver PIaln 1: Southeastern Idaho; U.S.G.S. Water Suppiy Paper BI8.

Tanaka, h. H., A. J. Hansen, Jr., and J. A. Skrivan, 1974, If g'tal-Nodel Study of Ground-Hater Hydrology, Columbla Bas1n Irrigation Project Area, Washington; Washington State Dept. Of Ecology Water Suppiy Bull. 40.

kicltor, hill11am C., 1970, Ground Water Resource Evaluat:on, Niew York, McGraw-yill Book Co.

Kood, P. R., 2960, Geology and Ground-Water Features of the Butte Valley Region S1skiyou County, California; U.S.G.S. Weter Sufply Paper 1491, 151 pp. 
APPENDICES

APENDIX A

A-1 


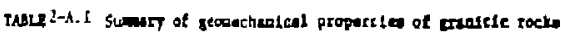

\begin{tabular}{|c|c|c|c|c|c|c|c|c|}
\hline \multirow[b]{2}{*}{ tock Tre 4 bencion } & \multicolumn{5}{|c|}{ Strell-titrul Properctes } & \multicolumn{2}{|c|}{ 5trenth Propert ies } & \multirow[b]{2}{*}{$\begin{array}{l}\text { Pefereace } \\
\text { at soures }\end{array}$} \\
\hline & $\begin{array}{l}\text { Young'a } \\
\text { 'bodulue } \\
\text { (cta) }\end{array}$ & g/ongty. & $\begin{array}{l}\text { balt } \\
\text { Modinlue } \\
\text { (GPa) }\end{array}$ & $\begin{array}{l}\text { Sheer } \\
\text { nodulue } \\
\text { (CFA) }\end{array}$ & $\begin{array}{l}\text { potuos's } \\
\text { Retto }\end{array}$ & $\begin{array}{l}\text { Dining } \\
\text { Comptestre } \\
\text { Strogeb } \\
\text { (bes) }\end{array}$ & $\begin{array}{l}\text { Teoull } \\
\text { scrength } \\
\text { (res) }\end{array}$ & \\
\hline $\begin{array}{l}\text { Grualte (courso- } \\
\text { grabed) } \\
\text { Polehifl Power Plant, } \\
\text { Lovelund, Colorado }\end{array}$ & $\begin{array}{l}26.6 \\
25.6\end{array}$ & $2.63(0.07 .9)$ & & & & $\begin{array}{l}72.1 \\
52.6\end{array}$ & $\begin{array}{l}2.63(0.05,9) \\
.02(.0002,9)\end{array}$ & $\downarrow$ \\
\hline $\begin{array}{l}\text { Pepmatita grasits } \\
\text { Polehill Pover Plant, } \\
\text { Loveleod. Colorado }\end{array}$ & & $2.62(0.09,27)$ & & & & $\cdot \cdot$ & & 1 \\
\hline $\begin{array}{l}\text { Group A } \\
\text { Group }\end{array}$ & 19.0 & & & & 0.10 & $\begin{array}{l}22.7(29.2 .3) \\
28.1(2.09 .3)\end{array}$ & & \\
\hline $\begin{array}{l}\text { Slighcly sltered } \\
\text { areolce } \\
\text { iraed Coul ee purpleng }\end{array}$ & 1.59 & & & & $0.1](4 R, 3)$ & 96.9 & & \\
\hline $\begin{array}{l}\text { tofect. } \\
\text { itoet County, Hashington }\end{array}$ & & & & & & \pm 6.3 & & $\mathbf{1}$ \\
\hline 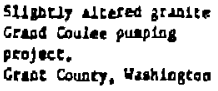 & $\begin{array}{l}9.97 \\
8.28\end{array}$ & $2.61(0.04,18)$ & & & $0.126(\mathrm{kn}, 3)$ & $\begin{array}{c}64.3 \\
33.2\end{array}$ & & 1 \\
\hline $\begin{array}{l}\text { Gruolte } \\
\text { Grud Coufte pueplag } \\
\text { plrat, } \\
\text { Grent County, Wahlogen }\end{array}$ & $\begin{array}{l}32.6 \\
12.4\end{array}$ & $2.63(0.07,12)$ & & & $0.14(N R, 3)$ & 148.8 & & $\mathbf{l}$ \\
\hline $\begin{array}{l}\text { Grualle } \\
\text { strada cenc site of } \\
\text { AEL-LRI-Liveropre }\end{array}$ & & & & & & 66,8 & & 2 \\
\hline Cranice, ao localsos & $31.3-58.6$ & & & & $0_{r} 15=0.24$ & & $3: 9-6,8$ & to \\
\hline
\end{tabular}




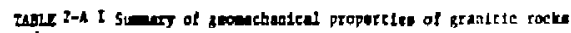

\begin{tabular}{|c|c|c|c|c|c|c|c|c|}
\hline \multirow[b]{2}{*}{ Beck Iype or Lacticton } & \multicolumn{5}{|c|}{ Stresu-nocrein Properties } & \multicolumn{2}{|c|}{ Serenach Propertipe } & \multirow[b]{2}{*}{$\begin{array}{l}\text { Inferimen } \\
\text { ot Source }\end{array}$} \\
\hline & $\begin{array}{l}\text { Tormsts } \\
\text { (Todulu } \\
\text { (TrI) }\end{array}$ & $\underset{8 /[D J}{D}$ & $\begin{array}{l}\text { sulk } \\
\text { Notulue } \\
\text { (GPa) }\end{array}$ & $\begin{array}{l}\text { Sheer } \\
\text { Hodulus } \\
\text { (EPI) }\end{array}$ & $\begin{array}{l}\text { Poluon't } \\
\text { Recio }\end{array}$ & 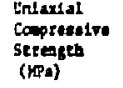 & 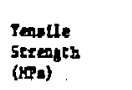 & \\
\hline $\begin{array}{l}\text { Granite } \\
\text { Veleocis Counts, as }\end{array}$ & $77.9(51,2)$ & 3.0 & & & & 156,5 & & 1 \\
\hline Grealce, Hat & 17.9 & 2.80 & & 32.3 & .27 & & & 11 \\
\hline Gran1te (Goloned), GA & 19.2 & 2.66 & & 10.3 & & 200.0 & 2.3 & 11 \\
\hline $\begin{array}{l}\text { Crante } \\
\text { Brtd Cayou dan olfe } \\
\text { mol Councy. Az }\end{array}$ & $53.8\left(\mathrm{NR}_{2}, 5\right)$ & $2.66(0.06,15)$ & & & .08 & $\begin{array}{l}134.8 \\
(56.2,4)\end{array}$ & $5.5(1.9,4)$ & 4 \\
\hline 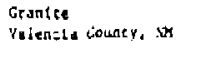 & 7. $2 \neq(\mathrm{BR}, 2)$ & $2.59(0.06 .2)$ & & & .07 & $\begin{array}{l}(25.5) \\
19.7 .2)\end{array}$ & & 4 \\
\hline $\begin{array}{l}\text { Grualice. so locacion } \\
\text { Biven (veachered) }\end{array}$ & & $2.74(H R, 8)$ & & & & & & 5 \\
\hline 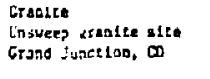 & 21.9 & 2.69 & & & .08 & $16+.8$ & 4.57 & 12 \\
\hline Crantice, Permat & 28.9 & 2.66 & & 15.9 & & & & 7 \\
\hline Gronlte. Ma:pland & 34.6 & 2.65 & & 25.4 & & 251.0 & & 7 \\
\hline CTanter, Jevads & 51]$. & 2.63 & & $\therefore .5$ & & 27,4 & & 7 \\
\hline Cronted, N. Caroline & 24.2 & 2.60 & & 12.3 & & 209.7 & & 7 \\
\hline Cadritc. go :ocdtlon & $43.1(7165,73)$ & & & & 0. 201 - 39.51 & & $5,62(16,6.29)$ & 6 \\
\hline 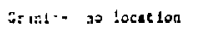 & 52.1 & $\therefore 67$ & & & 0.15 & 292,1 & & 9 \\
\hline fiddurted irsoses & 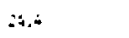 & & & & & 92.8 & & 9 \\
\hline
\end{tabular}




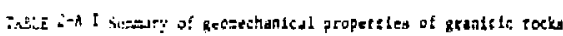

\begin{tabular}{|c|c|c|c|c|}
\hline \multicolumn{5}{|c|}{ Streus-situle Pasperties } \\
\hline $\begin{array}{l}\text { Young's } \\
\text { Yardulut: }\end{array}$ & Denstey & $\begin{array}{l}\text { Bulk } \\
\text { mode'ins }\end{array}$ & $\begin{array}{l}\text { Shear } \\
\text { Hodulug }\end{array}$ & Polssons \\
\hline
\end{tabular}

Rock Trpe of Locattos

$\left(6 p_{0}\right)$

Rieas

(G?a)

(cia)

Freont Canyon Crunte

$6 \div:$ :

2.62

Sel1d. Granite

10.7

2.6

Metdierl ourty

poxhgsile gatile

09.36

2.74

Cuagefea Quarry grantite bi.j

2.72

2. BI

Pleciedceo Quarry

coundise gralte

75.5

2.65

Pikt: Peak Grinlc

$33.6 \quad 2.67$

veachered)

P1ket inak Grotte

70.6

2.67

62.0

27.0

(cootrasoud)

Berre Granite

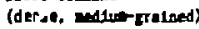

S1lver Fin Grafte

Serafthe Greak tumel

atte

Tllot bort, colorido

operts nowasto

Stradide fretl pllot

bote, Colorado

12.4

2.64

$60,6(46,1,40)$

52.4

$2.67(n, 30)$
Pates

Sitreth

3.14

0.18

0.24

0.16

107.2

0.25

0. 16

a. 37

0.31

Serengen

(APa)

hath Prage:-ir-

Tenshle
Scrennist

(4Pn)

7.7 :

Eeterence

ar source

9

9

9

9

i11.3

9

137.1

$\checkmark$

69.9

3.91

226.1

11.9

5

234.5

3.39

$0.205(.31,38)$

264.9

386.2

+ 15

arer.

$=$

Ft 


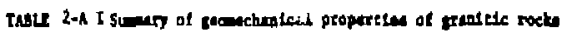

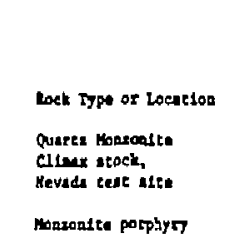

mazonite porplyn

Grand Coule puples

pluns.

Grant Coudt, Wushigron

Colvilia Grantto (silnincly colored)

Colvilie Grante

unalitered)

Monsonge porphy Grend coule puping

plant:

Grane Corsty, Menhingeos

Quercz morodit, MI

35.9

42,8

\section{guerts Diortte}

bridge Casjer dea oteo

tohnve Conbsy, N

Guetr Diofteo

Curdeo valler dea elte Dorge, ID

Quertz Diofte coels: Iridge Canfon dere stee Mohave County, Arlanot

\section{Hodrien}

(G)

$61.4-69.7$

Dinstey

2.6-2.66

Sodulus

53.8

$41.4(1.4,3) \quad 2.57(0.05,16)$

5.20

$\mathrm{L} 1.2$

2.75

$47.2\langle\mathrm{HB}, 2)$

$2.71(0,15,3)$

25.5

$(11.45,3)$

$1.00(4.5)$

$61.7(N R, 4)$

\section{Streun-erradn Propertice

Therese

Town's Butt sher

shore

(G:a)

20.0

4.82

$\$ 5.9 \quad 0.15$

$2.83(0.09,9)$
Polenos'.

tarlo

$.21-0.22$

$.18(\mathrm{krt}, 3)$

$124.8(.08 .140)$

0.20

$64, B$

$144+B$

7.45

0.6

170.6

112.4

stis

\section{Copresitn Tantio}

Serreth strments

(iver)

Strmat

Diterease

or source

118.6

$(19.3,2)$

$0.100 / 7 \pi, 3)$

87.6

$(9,7 ; 3)$

$0.11(2 \pi .6)$

d.4

$(13,1,3)$

13.5

$(2.59 .3)$ 


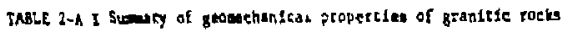

Stress-hetain Properteles.

Rock Type oe locat tar

Diotice Goelss

Sec s. I'SS RIT

Dinrite, no location

watallarid Batite i.ah

Dierite

hithizas

otorice (Gontasto diortce-gabbre) of

Gratiod fortce

Ineat frof dew Alte

Soovy Hith project,

dustrells.

\section{Pagarete.}

verson Palar bo

scitrest, Colorado

5t. cloud Gte

Granodirfite

(Precrivite)

\section{Butl Shea}

Modul

\begin{tabular}{|c|c|}
\hline $\begin{array}{l}\text { Yousas's } \\
\text { HoduJus } \\
\text { (GPA) }\end{array}$ & $\begin{array}{l}\operatorname{Den} 10) \\
8 /(x \rightarrow 3)\end{array}$ \\
\hline $\begin{array}{l}69,4 \\
(13,4,2)\end{array}$ & $\begin{array}{l}2.86(0.27,10) \\
2.87(0.09,3)\end{array}$ \\
\hline $69,7,72.4,127$ & $2.82(0.48 .5)$ \\
\hline $71.1(26-2,5)$ & $2.71(0.00 .5)$ \\
\hline $90.0(\$ 3.7,5)$ & $2.9(10.20,2)$ \\
\hline $71.1\{31.5,2\}$ & $3.03(0.01,2)$ \\
\hline $63.1(5,6,6)$ & $2,71(0.03,14)$ \\
\hline $18.3-20.6$ & $2,4(k, 4)$ \\
\hline
\end{tabular}

Shear
Yodulus
(GPa)

Po1mog's

fintio

$.98(k \pi, 7)$

$\begin{array}{ll}28.8 & 0.26(06,5) \\ (9.57,5) & \\ 35.9 & .29(06,5) \\ (12,6,2) & \\ 12.5 & \\ (9.45,2) & \end{array}$

$0.16(m, 6)$

$0.05-0.07$

Conlaxia!

Screshth
(:Pa)

serength

$04.2(5,1)$ $20 \mathrm{~h}, 4(\mathrm{sR}, 1)$

Meference

or Sourte

1

6

\&

246.9

227.6

$(.09,2)$

12

230.0

$(87,6,2)$

126.9

$(50.3,3)$

$1.451,97,5)$

,

เ

36.9

6,00

b5 


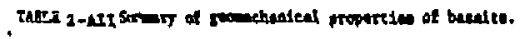

\begin{tabular}{|c|c|c|c|c|c|c|c|}
\hline \multicolumn{5}{|c|}{ Itrese-3tralo Peoration } & \multicolumn{2}{|c|}{ Strweth proparter } & \\
\hline $\begin{array}{l}\text { Tange's } \\
\text { Modulus } \\
\text { (era) }\end{array}$ & $\begin{array}{l}\text { Dentey } \\
f^{3}\end{array}$ & $\begin{array}{l}\text { Blt: } \\
\text { Hodolas } \\
\text { (CPE) }\end{array}$ & $\begin{array}{l}\text { Shest } \\
\text { Kodilua } \\
\text { (GPa) }\end{array}$ & $\begin{array}{l}\text { Poteroe' } \\
\text { patio }\end{array}$ & 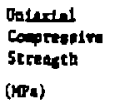 & $\begin{array}{l}\text { teonde } \\
\text { Stenteb } \\
\text { (HPa) }\end{array}$ & $\begin{array}{l}\text { Anfarteca } \\
\text { of 5outce }\end{array}$ \\
\hline
\end{tabular}

Toulenias bealt

South cosies de arte.

Colembis Mala

Peoject, Whablonted

$38.6(\mathrm{HR}, 5)$

$2.58(0,4,6)$

$.14(3 \mathrm{n}, 5)$

$82.1(37.9 .2)$

Landt, wo locition

$3.07(2.95-3.15)$

Bandt, as leciestor

$40.4(79,2,9) \quad 2.66(0.65,16)$

Bealt, Michlem

61.5

2.85

26.0

230.3

Baselte, Mehiten

2,97

33,9

258.3

Basele, Miehiem

70.3

2.91

29.6

thealt, Mchtgat

Bunit (altared)

Hientem

Buvily altered

Trdalar

2.70

18.5

0.0

398.6

257.9

81.6

171.7

delltic binle.

Henlis steres

S0.7

aysdular

Ep1datied bestt.

Hithiges 


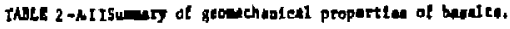

Streat-serato Erapart les

Loet Trpe 6 Leargat

sunele

See 32. TIBS RAR.

radtord. Thegon

Asate

retrida teat stite

AEC-LAl-Liverio

Risteis

Colusis Pleteav

Vesicular basalt

rayme das stze.

culaty. Iodia

Clesuy bault

black canyon dad at te.

solen. Ideho

Senolit

South Coulte dan sice.

Colubu Mara

project. Washingtan

$50.7(15,3) \quad 2.9(0.13 .5)$

Vendeular basolt

South Coulee das site.

Colubio Hota

project, Washing:

59. $3(0,6) \quad 2.62(0.04,10)$

Bult

Hodulue

(GP)

Shater

rodulu poienos"s

Nodviu

(GPa)

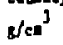

2. $22(0.11 .16)$

$62.3(32.4 .6)$

$2.7 \times(0.09 .13)$

34.9

2.676

$90.3(60.3-11\} .7) 2.9(2.4-3.1)$

$36.2(\mathrm{MR}, 3)$

$2.36(0.5 .6)$

$12.2(3 \mathrm{n}, 6)$

$2.62(0,16,10)$

Vequculat babale

South coulee das alte,

grojece, dashing: in

$4: 1(x k, j) \quad 2.47(0.24,12)$

\section{Streg ab Fropertsat}

Unifulel

Conren 1Fe Tenell

Strtajen Streigt:

(19a)

(MPa)

Mftrives

or sontes

$0.234 \quad[68.6(60.1,3)$

1

$31.950(16.790,3)$

148.0

13.1

1

$0,26(0,20,0,28) \quad 200(0-4,000) \quad 14(0-23) \quad 3$

$-13\{\mathrm{M}, \mathrm{J}) \quad 60(60,3\} 3) \quad 2.2(2,8,6)$

$\begin{array}{lll}.10(95.6) \quad 60139.3,3) & 1.1(.39,2)\end{array}$

$.18($ Nh. 3$) \quad[21.1(4 n, 1)$

$.21(4 n .6) \quad 95.9(45.1 .1)$

$.99($ Nh,6) $61.5(7.53 .3)$ 


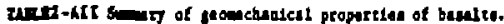

Strenbertuin Ropertiet

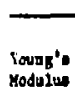

Rock TPa 4 Loention

Bandly alteted

angdulet

Cilettend bathe.

Hetripan

Juph Dr. backe

(dense)

Derca Benite Das

bunte (dean)

furediris dea batelt (demer)

Husag Ount besalt (denae)

IEC Hevide teit olt bacalt (dande, tiotprained, armethered)

\section{Bowed Porte the}

bessle (very dease, (Leortulued)

Lome Greolte batalt (mentve, comete)

Little croone bantt (assive, coupace)

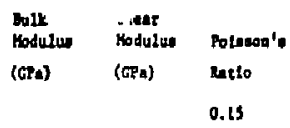

2.83

2.71

77,2

\section{Stete}

Conpesat strangeh

(IPa)

342.1
0.21

0.19

.3 .16

0.19

0.32

teforase of Soutce

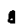

204.8

237.5

131.0

L26. 8

148.0

13,9

0.23

196.1

228.1

26.3

196.1

11 


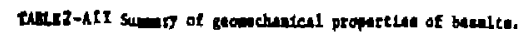

\begin{tabular}{|c|c|c|c|c|c|c|c|}
\hline \multicolumn{5}{|c|}{ Serepl-Strals Propeteriea. } & \multicolumn{2}{|c|}{ Strength Properten } & \multirow[b]{2}{*}{$\begin{array}{l}\text { Antareaca } \\
\text { ar source }\end{array}$} \\
\hline $\begin{array}{l}\text { Yougs'7 } \\
\text { Hodulua } \\
\text { (Ga) }\end{array}$ & $\begin{array}{l}\text { Deal Ity } \\
\text { aica }\end{array}$ & $\begin{array}{l}\text { Sult } \\
\text { rodulus } \\
\text { (Ga) }\end{array}$ & $\begin{array}{l}\text { Shane } \\
\text { Modulod } \\
\text { (Ga) }\end{array}$ & $\begin{array}{l}\text { Polados't } \\
\text { metlo }\end{array}$ & 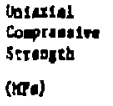 & $\begin{array}{l}\text { Tenolt } \\
\text { SErebatb } \\
\text { (HPL) }\end{array}$ & \\
\hline 8$] .4$ & & & & 0.29 & 355.1 & 16.5 & 9 \\
\hline 3B, & 2.06 & & & 0.16 & 166.1 & & 9 \\
\hline 93.1 & & & 11.5 & & $\Delta L 0.7$ & 22.1 & 9 \\
\hline $6 L .1$ & & 31.8 & 25.7 & & 169.9 & 15.5 & 9 \\
\hline
\end{tabular}




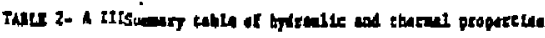

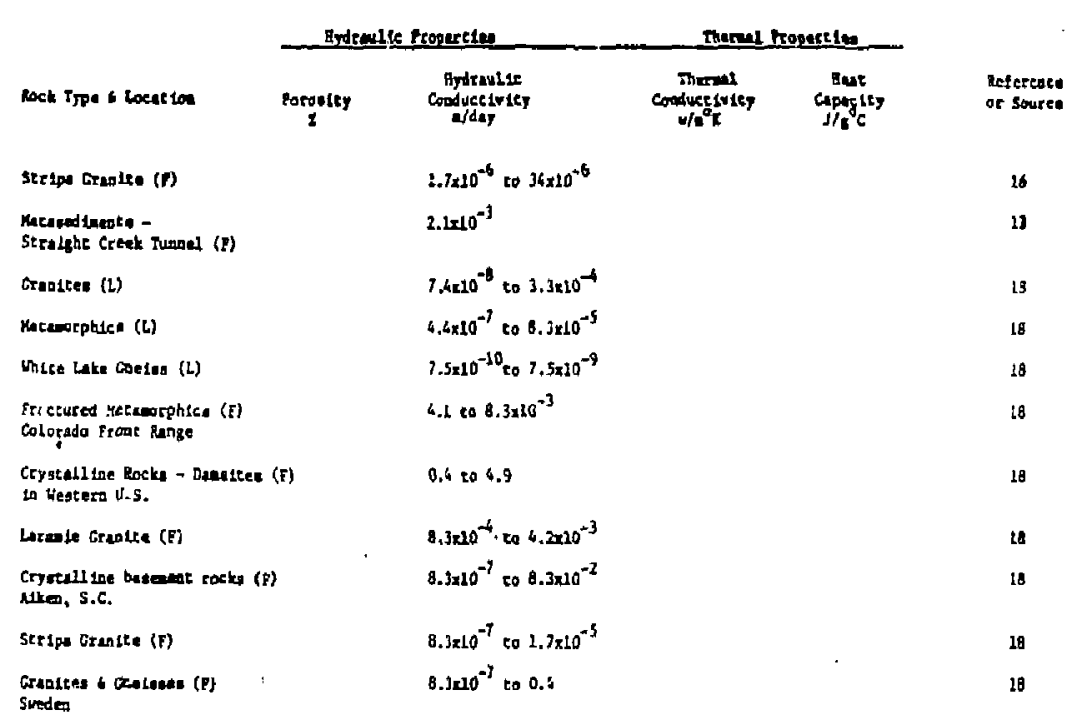

- 


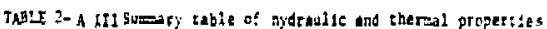

\begin{tabular}{|c|c|c|c|c|c|}
\hline \multirow[b]{2}{*}{ Pock Trpe b bocetion } & \multicolumn{2}{|c|}{ Hodreyils PTopercies } & \multicolumn{2}{|c|}{ Iheraei Proptrefes } & \multirow[b]{2}{*}{$\begin{array}{l}\text { Relriente } \\
\text { do Sourec }\end{array}$} \\
\hline & Perogity & 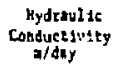 & $\begin{array}{l}\text { Thetpol } \\
\text { Conductivity } \\
\text { w/gl: }\end{array}$ & $\begin{array}{l}\text { Hest } \\
\text { topagitg } \\
J_{\mathrm{g}} \mathrm{C}\end{array}$ & \\
\hline $\begin{array}{l}\text { Burte Gronfre } \\
\text { (denst, wed (ut-grained) }\end{array}$ & 0.4 & L.T. $8 \times 20^{-2}$ & 2.37 & .92 & 9 \\
\hline $\begin{array}{l}\text { 51lvar Pluate Granite } \\
\text { stralghe Creek Tungel } \\
\text { stre, P1lot bore, Colo. }\end{array}$ & $1.19(2.5,25)$ & & & & 13 \\
\hline 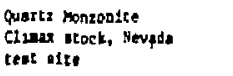 & $0.7-1.1$ & $\bullet$ & 3. & & 16 \\
\hline 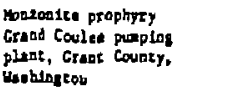 & $2.32(2.44,16)$ & & & & I \\
\hline 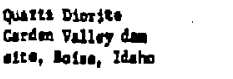 & $2.7(0.1)$ & & & & 1 \\
\hline 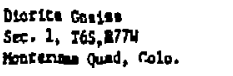 & $\begin{array}{l}0.19(1.07,10) \\
0.22(0.10,3)\end{array}$ & & & & 1 \\
\hline DLoxite, so ftre locactop & $2.7(1.1,12)$ & & & & 6 \\
\hline Mrgeralized Dlocite, Desh & $0 . \sin (1.65,5)$ & & & & a \\
\hline 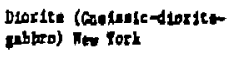 & $0.8(.4,2)$ & & & & 7 \\
\hline 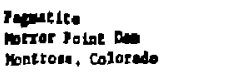 & $0.93(\mathrm{~m}, 4)$ & & & & 15 \\
\hline
\end{tabular}




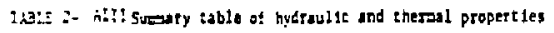

\begin{tabular}{|c|c|c|c|c|c|}
\hline \multirow[b]{2}{*}{ Rock Type \& Locat ton } & \multicolumn{2}{|c|}{ Hydrualic izoperties } & \multicolumn{2}{|c|}{ Therral Praperties } & \multirow[b]{2}{*}{$\begin{array}{l}\text { Ratcreace } \\
\text { of So,tec }\end{array}$} \\
\hline & $\begin{array}{c}\text { Porasty } \\
\quad\end{array}$ & $\begin{array}{l}\text { Hydrauise } \\
\text { Conducxtrity } \\
\text { a/ddy }\end{array}$ & $\begin{array}{c}\text { Therail } \\
\text { Conduegivity } \\
\text { v/a } k\end{array}$ & $\begin{array}{l}\text { Hect } \\
\text { copat Ity } \\
\mathrm{J} / \mathrm{g} \mathrm{C}\end{array}$ & \\
\hline Granite, Maryland & 0,0 & & & & 7 \\
\hline Oranite, Nerids & 0.09 & & & & 7 \\
\hline Grantee, Horth Cacol tind & 0.07 & & & & 7 \\
\hline Grasite, do location & $1.6(21.2,146)$ & $1(1,41)$ & & & 6 \\
\hline Grimite, so locution & 1.6 & & & & 9 \\
\hline Cudartan Graste & & & & & 9 \\
\hline $\begin{array}{l}\text { Preont Cengon Grantte } \\
\text { (conrse-tenined) }\end{array}$ & 0.8 & & & & 9 \\
\hline selue Grente & & & & & 9 \\
\hline $\begin{array}{l}\text { Metddest puatry porbytits } \\
\text { Grastes }\end{array}$ & 3.6 & & & & 9 \\
\hline Tol inke Querry Cronit. & 3.2 & & & & 9 \\
\hline Gagerair quers Gratte & 2.2 & & & & 9 \\
\hline 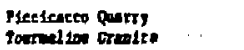 & 2.8 & & $\cdots$ & & 0 \\
\hline
\end{tabular}




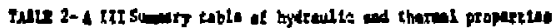

Grapte

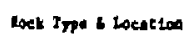

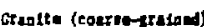

polobili pows pleas,

Levalind, colorido

Ptgatile grantito

Polehill Pour Plant,

Loveland, coloredo

Stight 1 a itered arastes

Grind Coulee punpling projete,

Giant County, Yashington

Gresice

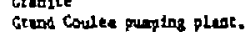

cront County, Maduiegton

Gronite

tranerp grante olte

Crand Juactea, coloredo

Gran1Fo, Vecouput

\section{Drdrulise Foperzies.}

Porouley Condrocetwate

7

1.0(1.4,27)

1.0

$2.61(1.01,10)$

$1.59(1.48,32)$

Thanel Fopercin

Thatwi

whet copejit

Tetercnet

or seuren

I 


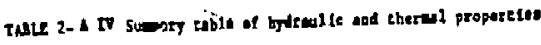

\begin{tabular}{|c|c|c|c|c|c|}
\hline \multirow[b]{2}{*}{ 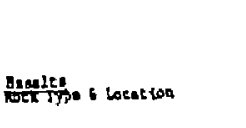 } & \multicolumn{2}{|c|}{ Hydroulle hopretiel } & \multicolumn{2}{|c|}{ Tharall propertes } & \multirow[b]{2}{*}{$\begin{array}{l}\text { Refczerce } \\
\text { or Source }\end{array}$} \\
\hline & Rerontey & $\begin{array}{l}\text { Iydraulle } \\
\text { Condyetivity } \\
\text { o/day }\end{array}$ & $\begin{array}{l}\text { Therwol } \\
\text { Conduetivits } \\
\text { v/oin }\end{array}$ & $\begin{array}{l}\text { Yeat } \\
\text { Copuctity } \\
\text { J/s }\end{array}$ & \\
\hline $\begin{array}{l}\text { Wo Du soment setholits (P) } \\
\text { Healtobe }\end{array}$ & & $4.2510^{-6} \mathrm{coc}$ & & & 18 \\
\hline 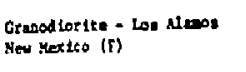 & & $5.8 \times 10^{-6}$ eo $6.6 \times 10^{-2}$ & & & to \\
\hline 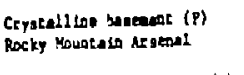 & & $4.9 \times 10^{-1} 206.6 \times 10^{-1}$ & & & LB \\
\hline Clisene Stock - Colorato (f) & & $2.3 \times 10^{-1}+01.5 \times 10^{-1}$ & & & $\therefore$ \\
\hline 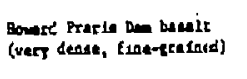 & 3.1 & & & & 9 \\
\hline sente & 10.2 & & & & 9 \\
\hline Dretset beneits & .264 & & 1,3 & .962 & 9 \\
\hline
\end{tabular}

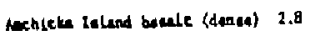




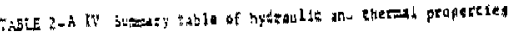

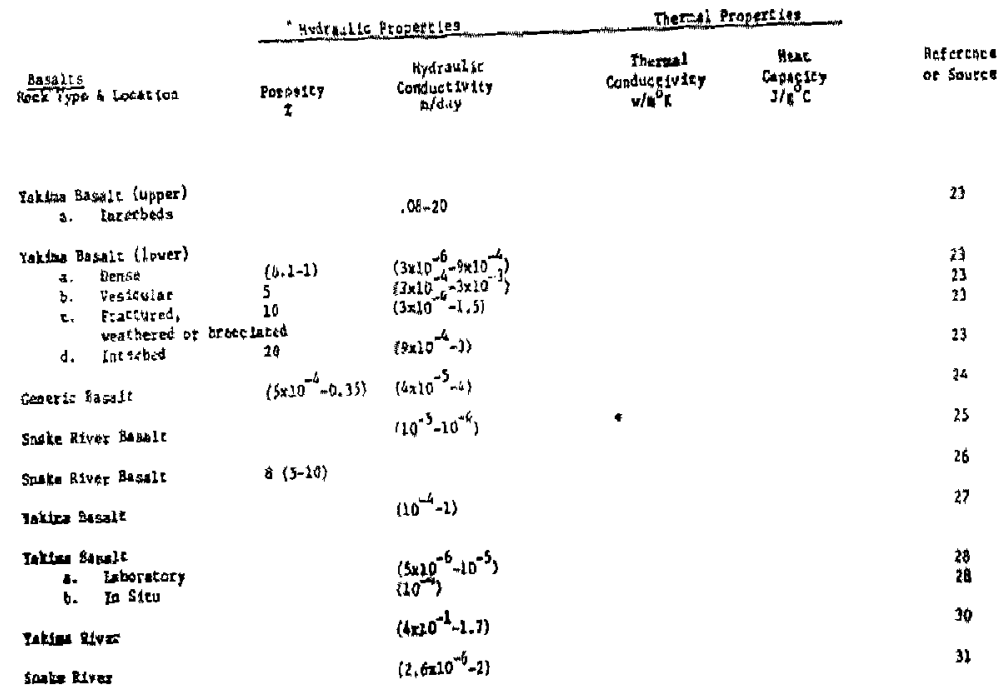




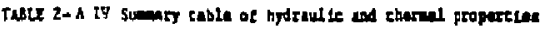

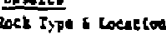

carmons ond fietured

same

Salk Rlver Plath

\section{Columbls RIver}

-. Jedinentaty Inzerbeds

t. Vipet takerflow ines

c. Sieep torert low zoars

d. Fentral basale perctog

\section{Hoiraule Properties}

Poroutcy Conductivit

1

ding $10^{3}\left(10-10^{5}\right)$

$\left(10^{-5}-(0)\right.$

10

\section{Tharel hoparelas}

cooductivity capeter

w/at distey

\section{iciterence}

of soures

19

to

20
1

21

21

at

$0.001(0.0001-0.1) 10^{-5}\left(10^{-5}-10^{-4}\right)$

$\begin{array}{ll}0.1(0.01-0.25) & 10^{-1}\left(10^{-2}-10\right) \\ 0.1(0.01-0.23) & 10^{-7}\left(10^{-6}-1\right) \\ 0.1(0.01-0.25) & 10^{-4}\left(10^{-5}-10^{-2}\right) \\ 0.001(0.0001-0.1) & 10^{-5}\left(10^{-5}-10^{-4}\right)\end{array}$

$10^{-2}$

22

$\left(4.8 \times 10^{-6}-8,6 \times 10^{-4}\right)$

$\left(6,8 \times 10^{-4}-3.62 \times 10^{-3}\right.$

$\left(10^{-3}-1\right)$

is breceinted

interbeds; and

clay and turt

itastures

d. تesteular

b. Tesnte

5

1. E..serbed, andy 20 
EXPLANATION OF NOTATION - APPENDIX A

All values given are presented in the Form

$A(P, C)$

where:
$A$ is the average value of a set of determinations
$B$ is the range of values observed
$C$ is the number of samples tested

$A$ may be specified as a range $A_{1}-A_{2}$ if values of $B$ and $C$ are uniknown. A may also represent the value of a single determination.

$B$ may be specified as a single value, $B$, or a true range $B_{1}-B_{2}$. If given as a single number, range represents the difference between the maximum and minimum values observed. The expression of range as a single value is comon practice in many publications of the U.S. Bureau of Reclamation. 
SOURCES FOR APPENDIX A

1. U.S. Bureau of Reclamation, Physical properties of some typical foundation rocks Concrete Laboratory Report \#⿰SP - 39 .

2. Kunar, A., 1968, The effect of stress rate and temperature on the strength of basalt and granite. Geophysics Vo1. 33 , No. 3, pp. 501-510.

3. Deju, R.A. et al, 1978, Structural Considerations in the Design of a Repository to Store Radioactive Waste in Basalt Formation.

4. Brandon, J.R., 1976, Rock Mechanics Properties of typicai Foundation Rock Types Engineering \& Research Center, Bureau of Reslamation REC-ERC-74-10.

5. Morris, D.A. and A.I. Johnson, 1948-60. Summary of Hydrologic \& Physical Properties of Rock and Soil Materials as Analyzed by the Hydrologic Laboratory of the USGS.

6. Judd, W.R., Strain Distribution around Underground Openings; Statistical Methods to Compile and Correlate Rocks. Properties, and preliminary results, Purdue University, Technical Report 2.

7. Windes, S.L., 1949, Physical Properties of Mir:. Rock Part I. Report of Investigation, R.I. 4459

8. -.-.-., Physical Properties of Mine Rock, Part II.

9. Kulhany, Fred H., Stress Deformation Properties of Rock and Rock Discontinuities.

10. Richey, J.E., 1968, Granite, Water Power.

11. Blair, B.F., 1955, Physical Properties of Mine Rock Part III, Bureau of Mines - Report of Investigation 5130.

12. -..--, 1956, Physical Properties of Mine Rock Part IV, Bureau of Mines - Report of Investigation 5244.

13. Engineering Geologic, Geophysical, Hydrologic \& Rock Mechanics Investigations of the Straight Creek Tumiel Site and Pilot Bore Colorado. Geologic Survey Professional Paper 815.

14. Carroll, Roderick D. et al, Elastic Module of Granite Rock from In situ Measurements of Seismic Velocity, USGS Prof. Paper 550-C.

15. Dodd, J., 1967, Morror Point Dam and Powerplant Foundations Investigations, Bureau of Reclamation Colorado River Storage Project, Colorado. 
16. Lundstrom and Stills, 1978, Large Scale Permeability Test of the Granite in the Stripa Mine and Thermal Conductivity Test, Lawrence Berkley Laboratory, LBL-7052.

17. Bureai of Reclamation, 1977, Ground Water Manual; A Water Resources Technical Publication, U.S, Dept. of Interior.

18. Brace, W.F., 1979, Permeabijity of Crystalline and Argillaceous Rocks, Preprint Submitted to Int. Jour. of Rock Mech. and Mine Science.

19. Schneider, K.J., and A. M. Platt, 1974, High-level Radioactive Waste Kanagement Alternatives, Battelie Pacific Northwest Laboratories, Richland, Wash., Rept. BNwL-1900.

20. Robertson, J.B, and J. T. Barraclough, 1973, Radioactive and Chemical Waste Tra?sport in uround Water at National Reactor Testing Station, Idaho; 20-year case history and digital model (abs); American Association of Petroleum Geologists Bulletin, V 57, n 8, Pp. 1603-1604.

21. Deju, R.A., et al, 1977, Environmental Factors Needed to Establish the Geotechnical Feasibility of Storing Radioactive Waste in Columbia River Basalt, RHO-ST-8.

22. Piper, A.M., 1975, Hypothetical Prctotype Sites of Repositories for Radioactive Wastes: Flood Basalt; ORNL Subcontract 3745.

23. National Waste Terminal Storage Program Preliminary Feasibility Study of Storage of Radioactive Waste in Columbia River Basalts for U.S. Energy Research and Development Administration 1976 .

24. Dames and Moore, 1978, Technical Support for GEIS: Radioactive Waste isolation in Geologic Formations, Y/OWI/TM-36/21. Vol. 21, Ground Water s.uvement and Nuclide Transport.

25. Barraclough, J. T., et al, 1976, Hydrology of the Solid Waste Burial Ground, As Related to the Potential Migration of Radionuclides, Idahe, National Engineering Laboratory; U.S.G.S. Open-File Béport 76-471.

26. Robertson, J.B., Robert Schoen and J.T. Barraclough, 1976 , The Influence of Iiquid Waste Disposal on the Geochemistry $n f$ Water at the National reactor Tesiing Station, Idaho 1952-1970; U.S.G.S. Report UC-70.

27. LaSala, A.M. Jr., and G.C. Doty, 1979, Preliminary Evaluation of Hydrologic Factors Related to Radioactive Waste Storage in Basaltic Rocks at Hanford; U.S.G.S. Open-File Report.

28. LaSala, A.M. Jr., G.C. Doty, and F.J. Person, Jr., 1972, A Preliminary Evaluation of Regional Ground-water Flow in South-Centrel Washington; U.S.G.S. WRD Admin. Report, 53 P. 
29. Foxworthy, B.L. and C.T. Bryant, 1967, Artificial Recharge Through a Well Tapping Basalt Aquifers at the Dalles, Oregon, U.S.G.S. Water Supply Paper 1594-E.

30. Eddy, Paul A., 1969, Geohydrology of the Columbia Basin Project Area, Washington, ass, in Nrothwest Science, $\mathrm{V} 43, \mathrm{n} 1$. p. 35.

31. Skibitzke, H.E. and J.A. da Costa, 1962, The Ground-Water Flow System in the Snake River Plain, Idaho - An Idealized Analysis; U.S.G.S. Water Supply Paper 153i,-D, Pp. 47-67. 
APPENDIX B

B-1 
Bulk Modulus, Modulus of Compression

\section{Hydraulic Conductivity}

Hydraulic Gradient (Dimensionless)

Modulus of Elasticity (Modulus of Deformation)
The ratio of the change in average stress to the change in unit volume.

If a porous medium is isotropic and the fluid is homogeneous, the hydraulic conductivity of the medium is the volume of water at the existing kinematic viscosity that will move in unit time under a unit hydraulic gradient through a unit area measured at right angles to the direction of flow.

Is the change in static head per unit of distance in a given direction. If not specified, the direction generally is understood to be that of the maximum rate of jecrease in head. The gradient of the head is a mathematical term which refers to the vector denoted by $\Delta h$ or grad $h$, whose magnitude $\mathrm{dh} / \mathrm{dI}$ is equal to the maximum rate of change in head and whose direction is that in which the maximum rate of increase occurs. The hydraulic gradient and the gradient of the head are equal but of opposite sign.

The ratio of normal stress to normal strain for a material under given loading conditions; numerically equal to the slope of the tangent (hence 'tangent modulus') or the secant (hence 'secant modulus') of a stressstrain curve. The use of the term Modulus of Elasticity is recommended for materials that deform in accordance with Hooke's Law, the term Modulus of Deformation for materials that deform otherwise. 
Permeability (Intrinsic) A measure of the relative ease with which a porous medium can transmit a liquid under a potential gradient. It is a property of the medium alone and is independent of the nature of the liquid and of the force field causing movement. It is a property of the medium that is dependent upon the shape and size of the pores.

Poisson's Ratio

The ratio of the transverse normal strain to the longitudinal normal strain of a body under uniaxial stress.

Porosity (Effective)

Shear Failure

Failure resulting from shear stresses. 
Specific Heat

$\underline{\text { Storage Coefficient }}$
Specific heat of a substance at temperature $v$ is defined as:

$$
v=\frac{d Q}{d v}
$$

Where $d Q$ is the quantity of heat necessary to raise the temperature of a unit mass of the substance through the small temperature range from $v$ to $v+d v$. It depends on both the temperature and the assumed mode of heating. It is expressed in:

$$
\frac{\text { calories }}{\mathrm{gm}-{ }^{0} \mathrm{C}}
$$

The specific heat of water at $15^{\circ} \mathrm{C}$ is $1 \mathrm{cal} / \mathrm{gm}-\mathrm{C}$. Some authors regard the above definition as that of heat capacity or heat capacity per unit map of the substance, and define the specific heat of a substance as the ratio of its heat capacity per unit map to that of water.

The storage coefficient is the volume of water an aquifer releases from or takes into storage per unit surface area of the aquifer per unit change in head. In a confined water body the water derived from storage with decline in head comes from expansion of the water and compression of the aquifer; similarly, water added to storage with a rise in head is accommodated partly by compression of the water and partly by expansion of the aquifer. In an unconfined water body, the amount of water derived from or added to the aquifer by these processes generally is negligible compared to that involved in gravity drainage or filling or pores; hence, in an unconfined water body the storage coefficient is virtually equal to the specific yield. 
Strain

Deformation per unit of

length. Normal Strain is the deformation per unit of length in the direction of the deformation. Shear Strain is the deformation per unit of length at right angles to the deformation or more commonly the relative change in the angle defining the sides of an infinitesimal elenent.

The maximum stress that a body can withstand without failing by rupture or continuous deformation, Rupture strength or breaking strength refers to the stress at the time of rupture. If a body deforms, after a certain stress has been reached, continuously without any increase in stress, this is also called strength. By conmon usage, it can be described as the greatest stress that a substance can withstand under normal short-time experiments, or the highest point on a stress-strain curve. 
The force per unit area, when the area approaches zexo, acting within a body. Biaxial Stress: The state of stress where either the intermediate or the minor principal stress equals zero. Effective Stress (Effective Pressure) (Intergranular Pressurel. The average normal force per unit area transmitted from grain to grain in a granular mass. It is the stress that is effective in mobilizing internal friction. Field Stress: The stress existing in a rock mass indeperdent of any man-made works. Residual Stress: Stress that exists in a formation owing to previously applied forces or deformations. Triaxial Stress: A state of stress where the three principal stresses have finite magnitudes, or simply a three-dimensional state of stress. Neutral Stress (Pore Fressure) (Pore Water Pressure) - Stress transmitted throug: the pore water (water filling the voids of the mass). Normal Stress : The siress component normal to a given plane. Principal Stress, acting normal to three mutually perpendicular planes intersecting at a point in a body, on which the shear stresses are zero. Major Principal stress : The largest (with egari to aign) principal stress. 
Thermal Conductivity

Thermal Diffusivity
Thermal conductivity is a material defined as:

$K=Q d$

$\frac { 0 } { ( v _ { 0 } - v _ { 1 } } \longdiv { s t }$

Where $Q$ is the guantity of heat which flows through a plate of the substance having a thickness d, cross-sectional area $s$, temperatures at the upper and lower surfaces of $v_{0}$ and $v_{1}$ '
over the time $t$.

The conductivity is generally not constant for the same substance but depends upon the temperature. For non-homogeneous solids, the conductivity varies from point-to-point es well as in direction at each point.

are:

Thermal diffusivity measures the change of temperature which would be produced in a unit volume o the substance by the guantity of heat which flows in unit time through a unit area of a layer of the substance of u..it thickness with unit difference of temperature between its faces. It is defined in terms of the thermal conductivity $(R)$, density $(p)$, and specific heat (c) as:

$$
k=\frac{k}{p c}
$$

Conduction of lleat in Solids, H.S. Carslaw and J.C. Jaeger oxford Oniv. Press, 1959, 2nd Edition. 


\section{Transmissivity}

Uniaxial Stress
The rate at which water of the prevailing kinematic viscosity is transmitced through a unit width of the aquifer under a unit hydraulic gradient. Though spoken of as a property of the aquifer, it embodies also the saturated thickness of the aquifer (b) and the properties of the contained liquid. It is equal to an integration of. the hydraulic conductivities across the saturated part of the aquifer perpendicular to the flow paths.

A state of stress where the minor and intermediate prin. cipal stresses are zero. 